Maira Deguer Misko

\begin{abstract}
A experiência da família da criança/adolescente em cuidados paliativos: flutuando entre a esperança e a desesperança em um mundo transformado pelas perdas
\end{abstract}

Tese apresentada ao Programa Interunidades de Doutoramento em Enfermagem da Escola de Enfermagem e Escola de Enfermagem de Ribeirão Preto da Universidade de São Paulo para obtenção do título de Doutor em Ciências.

Área de concentração: Enfermagem

Linha de pesquisa: Fundamentos Teóricos e Filosóficos do Cuidar

Orientadora: Prof ${ }^{a}$. Dr ${ }^{\mathrm{a}}$. Regina Szylit Bousso 
Nome: Maira Deguer Misko

Titulo: A experiência da família da criança/adolescente em cuidados paliativos: flutuando entre a esperança e a desesperança em um mundo transformado pelas perdas

Tese apresentada ao Programa Interunidades de Doutoramento em Enfermagem da Escola de Enfermagem e Escola de Enfermagem de Ribeirão Preto da Universidade de São Paulo para obtenção do título de Doutor em Ciências.

Aprovada em:

\section{Banca Examinadora}

Prof. Dr.

Julgamento:

Instituição:

Assinatura:

Prof. Dr.

Julgamento:

Instituição:

Assinatura

Prof. Dr.

Julgamento:

Instituição:

Assinatura

Prof. Dr.

Julgamento:

Instituição:

Assinatura

Prof. Dr.

Julgamento:

Instituição:

Assinatura: 


\section{DEDICATÓRIA}

Aos meus queridos pais, Kim e Cida, pelo cuidado, incentivo e dedicação em todos os momentos de minha vida. Minha eterna gratidão!

A minha irmã Natasha e ao meu cunhado Vinícius, pela paciência, apoio e parceria.

Aos meus avós, Elizeu, Cida e Mahiba, sempre presentes em minha memória, pelo exemplo de vida e dedicação a família.

"Gratidão é a memória do coração"

(Dostoievisky) 


\section{AGRADECIMENTO ESPECIAL}

A Profa. Dra. Regina Szylit Bousso, por acreditar em mim desde o início e com competência e carinho, encorajando-me a seguir nessa trajetória, acolhendo meus questionamentos e apoiando-me diante dos desafios. Obrigada pelo estímulo, por me fazer acreditar em mim e pela preciosa oportunidade de compartilhar de seus conhecimentos e experiências. Serei sempre grata! 


\section{AGRADECIMENTOS}

A Deus, peça vida e por guiar meus passos dia-a-dia.

À minha família, por todo apoio e torcida durante toda minha trajetória. Sinto-me abençoada pela família que tenho! Obrigada por todos os momentos compartilhados!

Ao meu tio Dito, com saudades, por todos os momentos de alegria e preciosas lições sobre a vida.

A todas as famílias que participaram deste estudo por compartilharem comigo suas histórias, ensinando-me grandes lições a cada dia!

Às famílias, crianças e adolescentes do ambulatório da Vnidade de Dor e Cuidados Paliativos, exemplos de superação e batalha diária pela vida.

À Profa. Dra. Regina Aparecida Garcia de Lima, pelas ricas contribuições no Exame de Qualificação e apoio no decorrer desta jornada.

À Dra. Andréa Yamaguchi Kurashima, pelas importantes contribuições propostas no Exame de Qualificação.

À Profa. Dra. Dulce Maria Rosa Gualda pelo incentivo e auxílio durante toda esta jornada.

À Profa. Dra. Zaida A. Sperli Geraldes Soller por partilhar suas experiências e pelo incentivo e apoio durante todo o caminho e, sobretudo, por ter me apresentado o mundo acadêmico.

A Profa. Dra.Elaine Buchhorn Cintra Damião e Profa. Dra. Lisabelle Mariano Rossato pela amizade e incentivo durante todos estes anos.

Ao Programa Interunidades de Doutoramento em Enfermagem da Escola de Enfermagem da Vniversidade de São Paulo, pela oportunidade de ampliar horizontes.

Ao Instituto da Criança, onde tudo iniciou, em especial a equipe da Unidade de Dor e Cuidados Paliativos, pela acolhida e pela possibilidade de compartilhar de seus conhecimentos.

À $\operatorname{Dr}^{a}$. Silvia Maria de Macedo Barbosa, por ter me apresentado o universo dos cuidados paliativos e pelo incentivo e amizade durante toda esta trajetória. 
A Dra. Eva Fabiana Sendin e a enfermeira Rita Tiziana Verardo Polastrini, pelo apoio fundamental durante o período da coleta de dados.

À toda Equipe da Unidad de Medicina Paliativa Del Hospital Universitario de Las Palmas de Gran Canaria Dr. Negrin, aqui representada na pessoa do Prof. Dr. Marcos Gómez Sancho, serei imensamente grata pelo acolhimento e incentivo. Obrigada por me permitirem compartilhar de seus conhecimentos e vivências.

À Universidad de Barcelona, pela possibilidade de intercâmbio, aqui representada na pessoa da Profa. Dra. María Getino Canseco, por ter me incentivado e me recebido durante este período de forma tão acolhedora.

Às equipes de cuidados paliativos do Hospital Materno Infantil Sant de Déu de la Universidad de Barcelona e do Institut Català d'Oncologia de Hospitalet de Llobregat, pela receptividade e vivências compartilhadas.

Aos meus queridos amigos, pela parceria, incentivo e estímulo durante todos esses anos. Obrigada pelos momentos vividos e histórias compartilhadas.

À Maiara e a Lucía, pela amizade e apoio nos momentos cruciais de finalização deste trabalho.

A todo o grupo do $\mathcal{N I P P E} \mathcal{L}$, pelas risadas, mas, sobretudo, pelas discussões que tanto contribuíram para meu crescimento.

À secretaria de Pós-Graduação da EEUSP, em especial à Silvana, Lúcia e Dayse, pelo acolhimento, auxilio e generosidade durante toda a jornada.

Ao serviço de Biblioteca e Documentação da Escola de Enfermagem da USP, pela disponibilidade de todos os seus funcionários.

À Janice Yunes è à Maria Helena Vargas, pelo auxílio nas áreas de editorações de texto e gráfica e, sobretudo, pela amizade e compreensão nos momentos finais de conclusão.

À CAPES, Coordenação de Aperfeiçoamento de Pessoal de Nível Superior, pelo apoio financeiro que possibilitou infra-estrutura para realização deste trabalho e pela confiança que dedica aos pesquisadores e à pesquisa científica. 


\section{"Nõ̃o sei"}

Se a vida é curta ou longa demais pra nós,

Mas sei que nada do que vivemos tem sentido,

Se não tocamos o coração das pessoas.

Muitas vezes 6asta ser:

Colo que acolhe,

Braço que envolve,

Palavra que conforta,

Silêncio que respeita,

Alegria que contagia,

Lágrima que corre,

Olhar que acaricia,

Desejo que sacia,

Amor que promove.

$\mathcal{E}$ isso não é coisa de outro mundo,

é o que dá sentido à vida.

É o que faz com que ela não seja

nem curta, nem longa demais,

Mas que seja intensa, verdadeira, pura..

Enquanto durar.

Feliz aquele que transfere o que sabe e aprende o que ensina.

(Cora Coralina) 
Misko MD. A experiência da família da criança/adolescente em cuidados paliativos: flutuando entre a esperança e a desesperança em um mundo transformado pelas perdas [tese]. São Paulo: Escola de Enfermagem, Universidade de São Paulo; 2012.

\section{RESUMO}

Este estudo teve como objetivos: compreender a experiência da família da criança/adolescente em cuidados paliativos, identificar os significados que ela atribui ao processo de ter um filho em cuidados paliativos, identificar as ações e estratégias desenvolvidas pela família que possui um filho em cuidados paliativos e construir um modelo teórico representativo do seu processo de vivenciar a trajetória de uma criança/adolescente nesta situação. Trata-se de uma pesquisa qualitativa orientada pelo Interacionismo Simbólico, enquanto referencial teórico e pela Teoria Fundamentada nos Dados como abordagem metodológica. $O$ estudo foi realizado no Ambulatório da Unidade de Dor e Cuidados Paliativos de um hospital público da cidade de São Paulo, de nível terciário, com características de ensino e pesquisa. Participaram dele 15 famílias de crianças/adolescentes em cuidados paliativos e os dados foram obtidos por meio da observação participante, entrevistas semiestruturadas e consultas a prontuários clínicos. A análise comparativa dos dados permitiu desvendar o significado da experiência da família nesse processo. Esta experiência é composta por quatro subprocessos: "Tendo a vida estilhaçada", "Manejando a nova condição", "Reconhecendo os cuidados paliativos" e "Reaprendendo a viver", que se inter-relacionam continuamente ao longo da experiência e consistem em desafios para os quais ela precisa empreender ações e estratégias a fim de superá-los. A articulação destes subprocessos viabilizou identificar a categoria central FLUTUANDO ENTRE A ESPERANÇA E A DESESPERANÇA EM UM MUNDO TRANSFORMADO PELAS PERDAS, a partir da qual se propõe um modelo teórico explicativo da experiência. O processo indica a experiência vivida pela família determinada a proporcionar 
a melhor condição de vida para o filho e para a unidade familiar antes e depois da sua morte. A esperança, perseverança e as crenças espirituais são fatores determinantes para que ela possa continuar lutando pela vida dele em um contexto de incertezas, angústia e sofrimento decorrentes desse quadro. Ao longo da trajetória, a família integra os cuidados paliativos em suas vidas e redefine valores com a ajuda das interações sociais vividas durante o processo. Os resultados trazem avanços para a área de cuidados paliativos. Conhecer a experiência possibilita que o profissional de saúde identifique e reconheça as suas limitações e forças de enfrentamento frente a este processo, para que possa elaborar e executar estratégias de intervenção com a família que tem um filho em cuidados paliativos. Os dados revelam, ainda, a importância da continência na relação entre o profissional e a família. Futuras pesquisas em outros contextos de cuidados paliativos podem contribuir com o modelo teórico ora apresentado.

PALAVRAS-CHAVE: Cuidados Paliativos. Família. Luto. Esperança. Enfermagem Pediátrica. 
Misko MD. The experience of the family of a child/teenager requiring palliative care: fluctuating between hope and hopelessness in a world transformed by loss [thesis]. São Paulo (SP), Brasil: Escola de Enfermagem, Universidade de São Paulo; 2012.

\section{ABSTRACT}

The present study aimed to understand the experience of the family of a child/adolescent requiring palliative care; identify the meanings the family attributes to the process of having a child in need of palliative care; identify actions and strategies developed by the family whose child requires palliative care and to build a theoretical model able to represent the family's process when living the experience of having a child/adolescent in need of palliative care. This is a qualitative study using the Symbolic Interactionism and Grounded Theory as theoretical and methodological frameworks, respectively. The study was conducted at the Pain and Palliative Care Outpatient Clinic of a tertiary teaching and research hospital in the city of São Paulo. A total of fifteen families of children requiring palliative care took part in the protocol and data were obtained by means of participant observation, semi-structured interviews and the perusal of medical records. Data comparative analysis made it possible to unveil the meaning of the family's experience in the child's palliative care process. The experience is made up of four sub-processes: "having their lives shattered"; "dealing with the new situation"; "recognizing palliative care" and "learning to live again", which are continuously interrelated throughout the experience and are the challenges the family has to act upon and devise strategies in order to overcome them. Articulation among these sub-processes allowed the identification of the core category FLUCTUATING BETWEEN HOPE AND HOPELESSNESS IN A WORLD TRANSFORMED BY LOSS, from which a theoretical model explaining the experience is proposed. The process shows the experience lived by the family, determined to offer the best quality of life they can to the child and to keep the family united before and after the child's death. Hope, 
perseverance and spiritual beliefs are the elements guiding the family to keep fighting for their child's life amidst uncertainties, anguish and suffering due to the losses lived during the process of their child's illness. Throughout this path, the family incorporates palliative care into their lives and redefines their values using the social interactions lived in this process. Results hereby presented bring advances to the field of palliative care. Knowing the family's experience makes it possible for the health care professionals to identify and recognize the family's weaknesses and strengths when coping with this process so that professionals can devise and implement intervention strategies to help families with children in need of palliative care. Data point to the importance of containment in the relationship between health care professionals and the family. Further studies in other contexts of palliative care may contribute to the model hereby presented.

KEYWORDS: Palliative care. Family. Grief. Hope. Pediatric nursing. 


\section{LISTA DE QUADROS}

Quadro 1 - Caracterização das famílias participantes ................................59

Quadro 2 - Exemplo de codificação aberta ............................................. 83

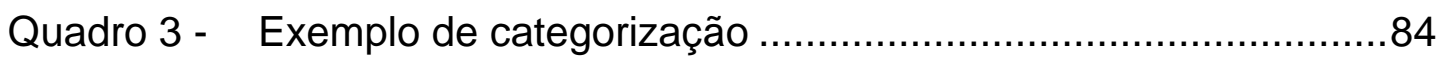

Quadro 4 - Categorias e subcategorias que compõem o processo ............90 


\section{LISTA DE ABREVIATURAS E SIGLAS}

\begin{tabular}{|c|c|c|}
\hline ACT & & $\begin{array}{l}\text { Association for Children with life-Threatening or Terminal } \\
\text { Conditions and their Families }\end{array}$ \\
\hline ANCP & - & Academia Nacional de Cuidados Paliativos \\
\hline apes & - & $\begin{array}{l}\text { Coordenação de Aperfeiçoamento de Pessoal de Nível } \\
\text { Superior }\end{array}$ \\
\hline EP - EE/USP & - & $\begin{array}{l}\text { Comitê de Ética da Escola de Enfermagem da } \\
\text { Universidade de São Paulo }\end{array}$ \\
\hline $\mathrm{NPq}$ & - & $\begin{array}{l}\text { Conselho Nacional de Desenvolvimento Científico e } \\
\text { Tecnológico }\end{array}$ \\
\hline CNS & 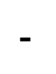 & Conselho Nacional de Saúde \\
\hline Conep/MS & - & $\begin{array}{l}\text { Comissão Nacional de Ética em Pesquisa do Ministério } \\
\text { da Saúde }\end{array}$ \\
\hline EE/USP & 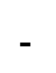 & Escola de Enfermagem da Universidade de São Paulo \\
\hline NIPPEL & 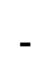 & Núcleo Interdisciplinar de Pesquisa em Perdas e Luto \\
\hline PDEE & - & Programa de Doutorado no País com Estágio no Exterior \\
\hline QV & - & Qualidade de vida \\
\hline QVRS & - & Qualidade de vida relacionada à saúde \\
\hline $\mathrm{RCPCH}$ & - & Royal Colleague of Paediatrics and Child Health \\
\hline SIOP & - & Comitê Internacional de Oncologia Pediátrica \\
\hline Sisnep & - & $\begin{array}{l}\text { Sistema Nacional de Informação sobre Ética em } \\
\text { Pesquisa envolvendo Seres Humanos }\end{array}$ \\
\hline תזா & & Teoria Fundamentada nos Dados \\
\hline & & World Health Organization \\
\hline
\end{tabular}




\section{SUMÁRIO}

1 INTRODUÇÃO

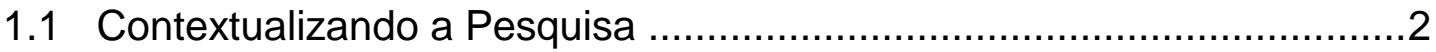

1.2 Revisão da Literatura............................................................... 8

1.2.1 Cuidados Paliativos ..............................................................

1.2.1.1 Cuidados Paliativos Pediátricos, família e criança ........................11

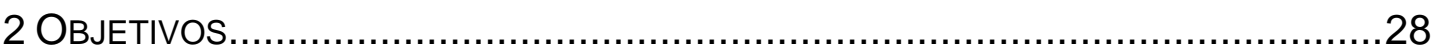

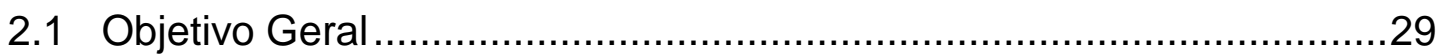

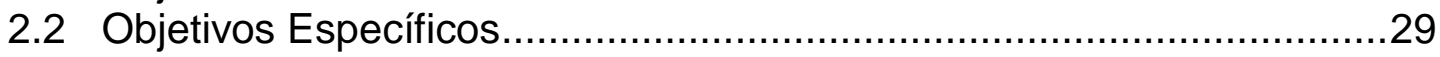

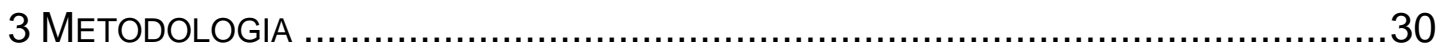

3.1 A Pesquisa Qualitativa ...................................................................

3.2 O Interacionismo Simbólico Como Referencial Teórico ...........................32

3.3 A Teoria Fundamentada nos Dados Como Referencial

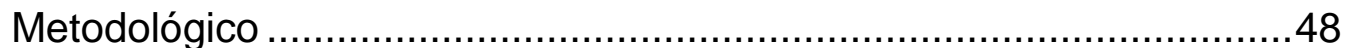

3.3.1 Implicações metodológicas da teoria fundamentada nos

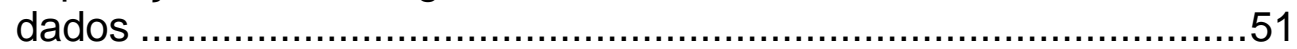

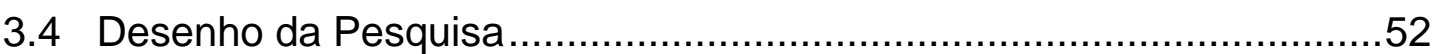

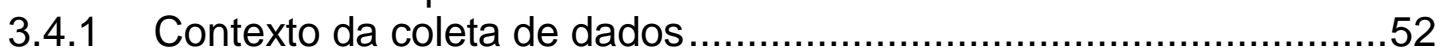

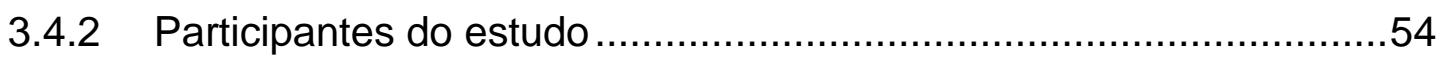

3.4.3 Coleta de dados ……..........................................................

3.4.4 Desafios e dificuldades encontrados durante a coleta de

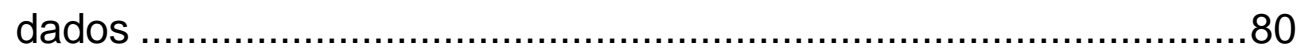

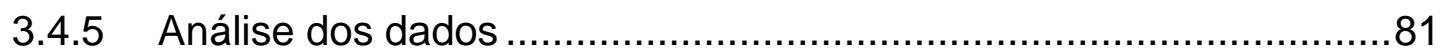

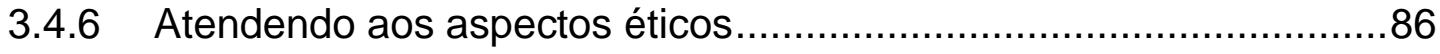

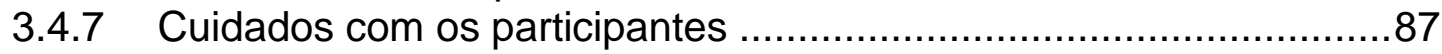

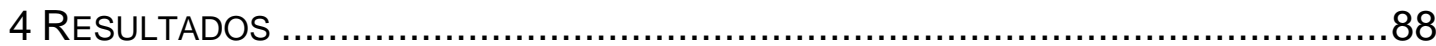

4.1 Compreendendo a Experiência da Família da Criança/Adolescente em Cuidados Paliativos ......................................89

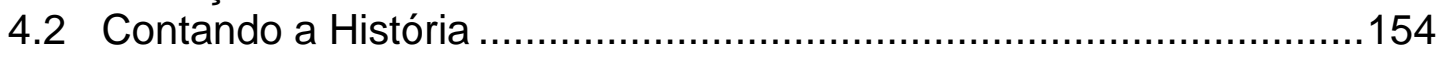

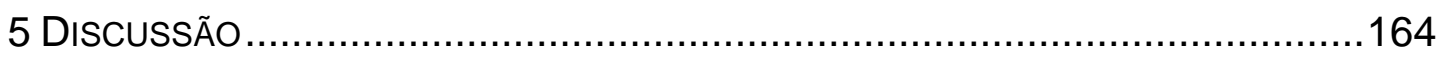

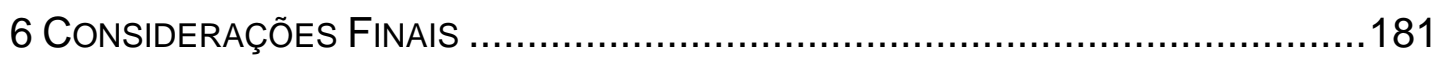

7 ANEXOS

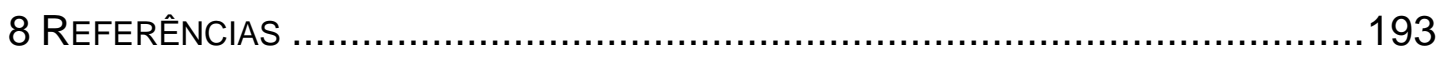


1 INTRODUÇÃO 


\subsection{Contextualizando a Pesquisa}

O interesse pela área da pediatria vem desde os tempos de minha graduação em Enfermagem, onde fui colocada, pela primeira vez, frente à criança doente e sua família. Entrar em contato com esse universo despertou-me para as interações existentes entre criança, família e equipe de saúde e, mesmo que ainda superficiais e imaturas, lançou-me o olhar para as necessidades, conflitos e sofrimento que estas famílias vivenciavam diariamente ao cuidar do filho na situação de doença e hospitalização.

O início de minha trajetória profissional aconteceu aprimorando-me no curso de Especialização em Enfermagem Pediátrica em um hospital terciário responsável pelo atendimento de crianças e adolescentes com patologias crônicas e complexas, muitas das quais ameaçavam ou limitavam seu tempo de vida. Nesta Instituição, fui contratada para exercer minhas atividades na unidade de pronto-socorro. Nesse sentido, onde, muitas vezes, a morte da criança era inevitável, mobilizou-me para questões referentes ao impacto que a situação da doença e morte provoca no sistema familiar e os rearranjos que são necessários para que a família possa enfrentar as adversidades que surgem à nova realidade e se readaptar a esta situação.

Neste período, em minha monografia de conclusão do curso, estudei as necessidades dos familiares acompanhantes de crianças com condições limitantes de vida e dependentes de tecnologia, muitas das quais internadas desde o seu nascimento. Isto, sem dúvida, contribuiu para o meu interesse nesse cenário de investigação, em uma perspectiva de abordagem mais compreensiva não só quanto aos agravos à saúde, mas também no tocante aos seus efeitos psicossociais, corroborando a necessidade e urgência de se colocar também a família como unidade de cuidado (Misko, 2001). 
Em minha prática profissional, percebi o desejo de ajudar as famílias a lidarem com a situação da doença, mas sabia que só isso não era suficiente para que o cuidado fosse realizado, mas me sentia sem recursos teóricos.

Minhas inquietações e o contato com a literatura pertinente aos estudos referentes à abordagem de cuidado centrada na criança e na família, mas também nas questões da família frente à experiência de doença de um de seus membros e como elas lidavam com esta situação, motivaram minha busca por subsídios que me permitissem alcançar os propósitos desejados. Isto veio de encontro ao curso de pós-graduação, com o mestrado realizado na Escola de Enfermagem da Universidade de São Paulo (EE/USP), o qual me proporcionou conhecimento e amadurecimento ao olhar essas famílias durante minha prática profissional.

Em minha Dissertação de Mestrado (Misko, 2005), procurei compreender a experiência da família ao manejar as intercorrências decorrentes do câncer infantil e quais os seus procedimentos em casa. Com isso, pude ampliar horizontes em direção às situações de busca pelo atendimento de emergência vivenciado pelas famílias.

Foi possível perceber, ainda, não só as situações de estresse e consequentes da definição que a família e a criança têm sobre a doença, como também os comportamentos resultantes do manejo da enfermidade, de onde se percebeu outro aspecto bastante presente na experiência: a incerteza. A busca pelo trato da doença em casa tem o significado de estar constantemente procurando eliminar os múltiplos sintomas, que podem levar à piora ou à perda do controle desse mal. As mães apontam as vivências do dia a dia com a criança em casa permeada pela incerteza de que podem advir outros eventos decorrentes dos sintomas, que podem aparecer em função do tratamento e da própria enfermidade. Agregado a essa experiência, nos momentos em que os sintomas aparecem, frequentemente todos precisam lidar com a incerteza, a insegurança, as indecisões sobre o momento em que precisam procurar ajuda externa, como o pronto-socorro (Misko e Bousso, 2007).

Para a família da criança com câncer, o futuro está intrinsecamente relacionado ao receio de não se conseguir tratar a criança, o que resultaria 
em sua morte. Neste caso, a busca pelo atendimento de emergências, durante a trajetória da doença, tem o significado de perda de controle da doença e de descoberta de nova complicação. Tal fato relembra a família sobre a gravidade da doença e a fragilidade do filho frente a esse mal. Neste sentido, frente ao câncer de seus filhos, assumem senso de responsabilidade para proporcionar-lhe o melhor cuidado, juntamente com a equipe. Sentem-se na obrigação de conhecer os efeitos do tratamento, para que possa saber o que e como vigiar e, assim, reconhecer todos os sintomas que possam ser manifestados. Além disso, busca antecipar possíveis complicações, encontrando-se prontas para agir a qualquer momento, caso necessário. Elas se veem como "peças-chave" durante todo o processo de doença (Misko e Bousso, 2007).

Com a conclusão do Mestrado, continuei na área assistencial, trabalhando também agora em uma enfermaria de oncologia pediátrica, o que me levou a vivenciar diretamente o atendimento a crianças cujo tratamento não tenha contemplado a sua cura, por mais eficaz que ele tenha sido. Em conjunto com minhas vivências profissionais anteriores junto ao cuidado de crianças com doenças para as quais a cura também não existia e que, muitas delas, viviam por longo período com a doença estabilizada, mas sofriam com as séries de limitações impostas pela mesma ou que faleciam como consequência da progressão da doença, defronto-me com os cuidados paliativos, um novo universo de cuidar que se abria à minha prática profissional.

Observar essas famílias e suas crianças trouxe à tona questões referentes ao impacto que pode ocorrer na estrutura familiar com a mudança do foco do tratamento curativo para o paliativo. Essa impõe necessidades específicas de cuidados no domicílio, quer para alívio e controle de sintomas, quer para preparo e adaptação em caso de perdas funcionais e, por vezes cognitivas, progressivas, até o início de uma trajetória que, inexoravelmente, evolui para a morte.

Desse quadro veio a necessidade de olhar de modo diferente para essas famílias e suas crianças, indo além das exigências específicas da doença e do próprio tratamento. Frente a isto, defrontei-me com a motivação de buscar recursos que me permitissem construir uma nova base de 
conhecimento que me levasse a uma prática de cuidado que permitisse atender as demandas da família e da criança frente a essa nova situação.

Tive a oportunidade de acompanhar algumas atividades ambulatoriais da equipe da unidade de dor e cuidados paliativos do hospital em que trabalhava e sempre procurei estar presente e participar quando esta realizava 0 atendimento às crianças internadas na enfermaria em que eu prestava assistência. Dessa forma, fui iniciando minha trajetória nesta área. Este contato permitiu-me estar próxima a crianças em cuidados paliativos portadoras das mais variadas patologias e suas famílias presenciando suas conquistas, temores, limitações e perdas no decurso do processo da doença e começando a perceber a dimensão que este atendimento poderia ter em suas vidas e de como seriam beneficiados com essa implementação. Isto porque, no ambulatório, havia crianças que já estavam em seguimento e conseguindo controle da progressão da doença por alguns anos, muitas das quais chegando até retomar atividades corriqueiras, como voltar à escola. Por outro lado, na enfermaria, vivenciava uma realidade diferente, geralmente com crianças em cuidados paliativos, mas em situação de final de vida. Estes dois contextos viabilizaram reconhecer que a experiência de ter um filho em cuidados paliativos não estava restrita às situações de final de vida.

Assim, atrás de conhecimentos teóricos que permitissem 0 aprimoramento de meu saber e de minha prática, pude realizar os cursos introdutório e avançado em cuidados paliativos ministrado pela instituição Pallium LatinoAmerica, formada por uma equipe interdisciplinar que atua nas áreas de assistência, educação e investigação em cuidados paliativos, com sede em Buenos Aires. Esta é uma referência na formação de profissionais na área de cuidados paliativos na América Latina.

Nesse sentido, o interesse pelo presente estudo iniciou a partir de minhas vivências profissionais e inquietações referentes ao cuidado a esta população e ganhou respaldo no curso de pós-graduação, nível doutorado na EE/USP, culminando, pois, nas seguintes questões de pesquisa:

- Como a família maneja o cotidiano da vida e os cuidados da criança/adolescente com a mudança do tratamento curativo para o paliativo? 
- O que significa qualidade de vida, ou falta dela, para essas famílias nessa situação de cuidados paliativos?

- Quais aspectos elas consideram importantes para a preservação da qualidade de vida?

- Será que todas as famílias conseguem se dar conta da realidade de que a doença da criança não pode mais ser curada, de sua progressão e aproximação da morte do filho?

- Quais fatores ajudam ou atrapalham esse entendimento? O que faz com que as famílias percebam e entendam isso? Em que momento isso se dá?

Este conjunto de indagações culminou na seguinte pergunta de pesquisa: Como a família experiência o processo de cuidados paliativos de sua criança/adolescente?

O curso de Doutorado facultou a participação no Núcleo Interdisciplinar de Pesquisa em Perdas e Luto (NIPPEL), que é um grupo de pesquisa da EE/USP cadastrado no Conselho Nacional de Desenvolvimento Científico e Tecnológico (CNPq), que tem realizado pesquisas com o objetivo de desenvolver e disseminar conhecimento na área de perdas, cuidados paliativos e luto, enfocando a assistência ao indivíduo e à família e o aperfeiçoamento dos profissionais de saúde quanto ao cuidado no fim da vida, ampliando estratégias para a promoção do cuidado à família. Têm-se realizados alguns trabalhos que trouxeram resultados importantes para compreensão da experiência de luto para a família, sobretudo com famílias de crianças hospitalizadas, com doenças avançadas, com câncer, cardiopatia e possibilidade iminente da morte (Misko, 2005, Bousso, 2008). Além disso, também têm sido realizados estudos que envolvem as experiências de profissionais de saúde frente ao cuidado e pacientes em situações de final de vida (Poles, 2006; Silva, 2011; Paganini, 2011).

Nesse período, realizei, ainda, um intercâmbio por meio do Programa de Doutorado no País com Estágio no Exterior (PDEE) financiado pela Coordenação de Aperfeiçoamento de Pessoal de Nível Superior (Capes). Nesse período, minhas atividades estiveram vinculadas à Unidad de Medicina Paliativa Del Hospital Universitario de Gran Canaria Dr. Negrín 
(Las Palmas de Gran Canaria - Espanha) e à Universidad de Las Palmas de Gran Canária, sob a supervisão do Prof. Dr. Marcos Gómez Sancho e estiveram voltadas para a área de ensino, pesquisa e assistência em cuidados paliativos. O estágio também incluiu atividades junto à Escola de Enfermagem da Universidade de Barcelona, sob a tutoria da professoradoutora María Getino Canseco e a dois serviços específicos de cuidados paliativos locados nas instituições: Hospital Materno Infantil Sant Joan de Déu e no Institut Català d'Oncologia de Hospitalet de Llobregat.

Essas experiências permitiram conhecer e participar do funcionamento dos serviços e da assistência prestada nesse atendimento em particular, bem como as interações estabelecidas entre pacientes, famílias e a equipe interdisciplinar envolvida no processo nos contextos de hospitalização, ambulatório e assistência domiciliária. No serviço pediátrico, o atendimento abarcava uma série de patologias, incluindo doenças oncohematológicas, neurológicas e síndromes genéticas variadas, sendo notório o envolvimento da criança na participação do planejamento de seu plano de cuidado, respeitando seu desenvolvimento e seu status clínico.

Em todos os serviços, observei a integração existente entre as equipes de cuidados paliativos nos diferentes níveis de atenção à saúde e entre as especialidades médicas junto ao grupo paliativista, possibilitando que os pacientes e seus familiares fossem encaminhados à assistência paliativa precocemente. $\mathrm{O}$ seguimento era realizado em diferentes momentos da trajetória de doença do paciente e, em muitos casos, era possível a transição gradual do foco de cuidado de cura para o paliativo com pacientes e seus familiares. Dessa maneira, tornando-se realidade que as decisões referentes ao período de final de vida pudessem ser discutidas e acordadas conjuntamente entre pacientes, família e equipe à medida que a progressão da doença acontecia.

A partir deste momento, apresento uma revisão de literatura que teve como objetivo dar contribuições científicas referentes a estudos relacionados à criança/adolescente em cuidados paliativos e suas famílias e reunir elementos que pudessem auxiliar no entendimento dessa nova situação. 


\subsection{Revisão da Literatura}

\subsubsection{Cuidados Paliativos}

Define-se como cuidados paliativos a

[...] abordagem que promove qualidade de vida de pacientes e familiares diante de doenças que ameaçam a continuidade da vida, através de prevenção e alívio do sofrimento. O que requer a identificação precoce, avaliação e tratamento impecável da dor e outros problemas de natureza física, psicossocial e espiritual (OMS, 2002).

A abordagem paliativa engloba os cuidados ativos e globais a pacientes e a suas famílias que devem ser realizados por equipe multidisciplinar, em um período em que a doença já não responde aos tratamentos curativos ou que apenas prolonguem a vida, sendo um de seus grandes objetivos acrescentar qualidade de vida aos dias e não dias à vida, priorizando os cuidados emocionais, psicológicos e espirituais, mais do que os cuidados técnicos e invasivos, que podem gerar maior sofrimento ao paciente e à sua família (Twycross, 2003).

Os cuidados paliativos têm origem a partir da década de 1960 e vêm da literatura relacionada aos hospices, palavra de origem inglesa que significa abrigo. Na Idade Média, eram os religiosos que prestavam os cuidados nesses locais, que serviam de abrigo para peregrinos e doentes, que, uma vez recuperados, continuavam seu caminho. Local onde muitos também acabavam morrendo sob os cuidados leigo e caridoso (Maciel, 2008).

Se buscarmos no latim, encontramos a palavra paliativo como derivada de pallium, nome dado a uma espécie de cobertura ou toldo que servia, na Antiguidade, para a proteção de reis e autoridades, sendo ainda hoje utilizado em procissões católicas como cobertura para o Santíssimo Sacramento. Por essa analogia, pode-se dizer que paliativo tem como finalidade proteger a vida humana, mesmo nos contextos em que a cura já não é mais possível, mantendo a dignidade da vida humana e os cuidados prestados em um contexto onde deficiências físicas e sofrimento podem limitá-la (Matsumoto, 2009).

Buscando combater a situação de desamparo dos pacientes fora de possibilidade de cura, pelo avanço tecnológico e pelas ciências médicas, 
profissionais europeus e americanos começam a se destacar na luta pela humanização do cuidado. Na década de 1960, no Reino Unido, tem início o movimento "hospice" moderno e, com ele, o desenvolvimento dos cuidados paliativos (Rodrigues, 2004).

$O$ aumento do interesse na área dos cuidados paliativos foi reflexo do estabelecimento do primeiro hospice, o Saint Christopher's Hospice, em 1967, na cidade de Londres, fundado por Cicely Saunders. A partir deste instante, os hospices passaram a ser sinônimo de assistência paliativa (Seymour et al., 2005). Aqui, o foco da atenção passa a ser por pessoas que se encontravam sem opção de recursos terapêuticos e que permaneciam sozinhas enquanto esperavam a evolução final da doença, submetidas a intensos sofrimentos físico, moral, social, emocional e familiar. Saunders, buscando confortar e aliviar o sofrimento dessas pessoas, reaviva o termo hospice, agora representando os cuidados ao fim da vida (Lima, 2002).

A área de cuidados paliativos - em seu campo de conceito, instrumentos e metodologia - ainda se encontra em construção, mantendo sua definição e estratégias a partir da prática como um desafio para as equipes. Nesse campo, as ações são determinadas por fatores que envolvem questões políticas, éticas, culturais, sociais e subjetivas e não somente por ações de competência técnico-científicas, baseadas em processos diagnóstico e terapêutico. Desse modo, o desafio das equipes está em encontrar na sua rotina de trabalho um equilíbrio harmonioso entre razão e emoção junto às pessoas que recebem cuidados paliativos (Remedi et al., 2009).

Com o propósito de realizar um mapeamento da presença e do estado de desenvolvimento de serviços de cuidados paliativos no contexto mundial, foi realizado um estudo pelo International Observatory on End of Life Care, da Universidade de Lancaster, no Reino Unido, que evidenciou que somente 115 nações (49\%), das 234 que compõem a Organização das Nações Unidas, contam com serviços estruturados de assistência paliativa. Com base no nível de desenvolvimento da estrutura paliativa apresentada, estas nações foram divididas em quatro grupos:

a) Países sem nenhuma atividade paliativa conhecida. 
b) Países sem serviços estruturados, mas com pessoas buscando capacitação para tal.

c) Países que apresentam serviços isolados.

d) Países com serviços estruturados e com políticas que garantem à população sua aplicação, contando com centros de educação e pesquisa.

Este último grupo é constituído por países europeus desenvolvidos em sua maior parte e representa apenas $15 \%$ das nações. O Brasil conta com serviços estruturados e legislação, mas carece de centros de educação e pesquisa, pertencendo ao grupo "c" (Wright, 2008).

A área paliativa ainda é recente no Brasil. $O$ primeiro serviço de cuidados paliativos foi instituído no Rio Grande do Sul, em meados de 1983 (Rodrigues, 2004). Em 1997, foi criada a Associação Brasileira de Cuidados Paliativos, primeira associação nacional de profissionais que passou a atuar disseminando esta filosofia e, em 2005, foi fundada a Academia Nacional de Cuidados Paliativos (ANCP), que, conjuntamente, vem buscando 0 reconhecimento legal deste enfoque de cuidar e possibilitar que esta filosofia possa ser aplicada em todo o território nacional (Araujo, 2011).

O Ministério da Saúde brasileiro publicou, em 3 de janeiro de 2002, a Portaria GM/MS n 19 , onde instituiu o Programa Nacional de Assistência à Dor e Cuidados Paliativos, o que proporcionou debates sobre a temática e capacitação profissional e a revisão de posturas pertinentes ao cuidado do paciente portador de doença crônico-degenerativa ou em fase final de vida e seus familiares. Atividades conjuntas entre a Sociedade Brasileira para 0 Estudo da Dor, do Ministério da Saúde, e a ANCP resultaram na Portaria ${ }^{\circ}$ 3150, de 12 de dezembro de 2006, que estabelece a criação da Câmara Técnica em Controle da Dor e Cuidados Paliativos, com composição e funções específicas, revogando-se a Portaria n 19, de 2002 (Maciel, 2008).

Atualmente, conforme dados das entidades de profissionais paliativistas, aproximadamente 40 serviços oferecem este tipo de assistência no Brasil, o que é pouco se pensarmos na extensão geográfica e nas necessidades de nosso país (Matsumoto,, 2009). A grande maioria dos serviços presta atendimento a pacientes oncológicos, mas já se encontram 
serviços de cuidados paliativos específicos para 0 atendimento às populações neonatal, pediátrica, a pacientes com HIV/aids e o início de discussões para a viabilização de sua implementação no ambiente de terapia intensiva (Maciel, 2008; Araujo, 2011).

\subsubsection{Cuidados Paliativos Pediátricos, família e criança}

A Association for Children with life-Threatening or Terminal Conditions and their Families (ACT) e Royal Colleague of Paediatrics and Child Health (RCPCH) definem cuidados paliativos como

[...] abordagem de cuidado total e ativo, englobando os elementos físico, emocional, social e espiritual. Ele centra-se no aumento de qualidade de vida para a criança e oferece suporte para a família incluindo controle dos sintomas angustiantes, provisão de substitutos para os cuidados e de cuidado durante a morte e o luto (ACT, 2009).

Segundo o World Health Organization (WHO), 2009, uma definição apropriada para cuidado paliativo pediátrico engloba o que se segue:

- cuidado ativo e total à criança no contexto de seu corpo, mente e alma, envolvendo também o suporte prestado à família;

- cuidado paliativo inicia-se quando a doença é diagnosticada e continua, mesmo que a criança receba ou não tratamento com objetivo curativo;

- profissionais de saúde devem avaliar e aliviar os sofrimentos físico, psicológico e social da criança;

- cuidado paliativo efetivo requer abordagem multidisciplinar que inclua a família e a utilização de recursos da comunidade, podendo ser implementado com sucesso, mesmo quando os recursos são limitados;

- este cuidado pode ser oferecido por instituições terciárias, em centros de saúde e na própria casa da criança.

- o cuidado também deve ser precoce no curso da doença, em conjunção com outras terapias, que têm como objetivo prolongar a vida com a químio ou radioterapia, e inclui as investigações necessárias para melhor entender e manusear as complicações clínicas. 
Os avanços na área das ciências da saúde vêm proporcionando um novo cenário em nosso meio, onde a possibilidade de cura de doenças vem sendo a regra e não mais a exceção. Assim sendo, este novo contexto possibilitou a diminuição do número de mortes decorrentes das complicações da prematuridade e elevou a expectativa de vida de crianças portadoras de doenças crônicas, além de facultar também o aumento no índice de cura de doenças oncológicas pediátricas. A evolução tecnológica e o progresso da ciência médica vêm proporcionando que, cada vez mais, crianças vivam com "[...] condições crônicas complexas [...]" (Barbosa, 2010), as quais são definidas como uma "[...] condição médica que apresenta ao menos 12 meses de sobrevida e envolve o acometimento de um ou mais sistemas de órgãos que necessitam do atendimento pediátrico especializado" (Feudtner et al., 2001). Na oncologia, as novas terapias têm buscado a melhora da qualidade de vida e a integração do indivíduo à sociedade, além de tornar possível uma taxa de sobrevivência que tem excedido, em alguns casos, $70 \%$ de cura dos pacientes (Haut, 2005; Mitchellet al., 2005, Kars et al., 2011).

Apesar deste panorama, que propiciou aumento na sobrevida de crianças convivendo com as mais diversas patologias, encontra-se um grupo de pacientes que não atingirá a cura, beneficiando-se da filosofia paliativa. $A$ partir do momento em que esta não for mais possível, paciente, família e equipe de saúde enfrentarão o grande desafio na busca e implementação de condutas que permitam a melhoria da qualidade de vida por meio do alívio da dor e por outros sintomas, como o atendimento às suas necessidades espirituais e psicossociais (Monterosso et al., 2009; Knapp et al., 2010; Bergstraesser, 2012).

O crescimento, no campo da medicina paliativa, para adultos não tem sido replicado na pediatria. Apesar do aprimoramento da consciência da necessidade de um cuidado compreensivo com as crianças que estão morrendo e com os seus familiares, o cuidado paliativo ainda permanece pouco desenvolvido no ambiente pediátrico (Monterosso et al., 2009; Floriani, 2010). As necessidades de crianças criticamente doentes e de suas famílias não têm sido incluídas nos modelos de cuidados paliativos, 
reforçando que os modelos existentes para o público adulto não abarcam todas as necessidades das crianças em situação paliativa. Vale ressaltar que nem toda criança que recebe esses cuidados encontra-se em fase final de vida; essa filosofia de cuidado pode e deve ser concomitante a intervenções destinadas à cura ou à estabilização de doença com prolongamento de vida (Barbosa et al., 2008; Knapp et al., 2010).

No contexto pediátrico, os cuidados paliativos diferem daquele prestado ao adulto em inúmeros aspectos. Na pediatria, estes devem levar em consideração fatores fisiológicos, de desenvolvimento, preferência pelo cuidado domiciliar sempre que possível, no decorrer da trajetória do câncer, variação no momento de transição para uma abordagem exclusivamente paliativa e o envolvimento dos pais no cuidado e processos de tomada de decisão (Monterosso et al., 2007; Barbosa et al., 2008; Monterosso e Kristjanson, 2008, Bergstraesser, 2012).

No campo da pediatria, muitas patologias, umas raras, podem ser responsáveis pela inclusão da criança em um programa de cuidados paliativos e também ocasionar sua morte. Convém deixar aqui registrada, ainda, uma série de "distúrbios" crônicos, como: erros inatos de metabolismo, síndromes genéticas, fibrose cística, epidermólise bolhosa, aids, câncer, condições cardíacas complexas e doenças neuromusculares, entre outras. É válido enfatizar que apenas $4 \%$ das mortes no contexto pediátrico são causadas por doenças oncológicas (Barbosa, 2010).

Assim, Barbosa, (2010) afirma que:

Muitas crianças que podem se beneficiar dos CP vivem com uma
patologia que apresenta um curso imprevisível de tempo, podendo
variar de um curto prazo que rapidamente leva a morte a doenças
crônicas complexas que podem evoluir por anos. O processo de
morrer, por sua vez,pode se prolongar, por exemplo,em uma
criança portadora de leucemia com recidiva da doença, enquanto
outras crianças podem ter um declínio lento como resultado de
uma vida naturalmente encurtada, como, por exemplo, os
pacientes com deficiências psicomotoras.

Frente a isso, a ACT e o RCPCH definem cinco categorias de crianças e uma específica de familiares que se beneficiariam da inclusão da filosofia paliativa, as quais são descritas a seguir (ACT, 2009) 
a) Crianças que apresentam condições onde há possibilidade de tratamento curativo, porém pode haver falha do mesmo, não se atingindo a cura. Exemplo: câncer, excluídas crianças em manutenção por longo período.

b) Crianças com doenças nas quais a morte prematura é esperada, mas o tratamento intensivo pode prolongar a sua vida com qualidade. Exemplo: HIV e fibrose cística.

c) Crianças com doença progressiva, para as quais não há prognóstico de melhora do quadro, sendo o objetivo do tratamento exclusivamente a paliação, podendo esse quadro perdurar por anos. Exemplo: distúrbios metabólicos, epidermólise bolhosa e xerodermia pigmentosa.

d) Crianças com deficiências neurológicas, que, embora não sejam progressivas, induzem a vulnerabilidade e complicações que podem levar à morte prematura, as quais se tornam vulneráveis a complicações que podem acelerar a deterioração. Exemplo: encefalopatia.

e) Recém-nascidos com prognóstico reservado.

f) Familiares que perderam suas crianças vítimas de morte súbita do lactente, morte precoce ou por trauma do recém-nascido.

Merecem destaque, com relação aos cuidados paliativos, dois termos adicionais que precisam ser definidos e englobam as patologias mencionadas nas cinco categorias arroladas anteriormente: "doenças que ameaçam a vida"; estas descrevem as doenças para as quais há tratamento curativo disponível, mas que pode falhar, sendo o exemplo mais comum o câncer. O termo "doenças que limitam a vida", são aquelas para as quais não há esperança de cura e, consequentemente, as crianças ou jovens morrerão, sendo que algumas delas causam progressiva deterioração, levando a criança à dependência importante dos pais e cuidadores (Dussel e Medin, 2004; ACT, 2009).

Assim, os cuidados paliativos na área pediátrica devem ser os responsáveis por fornecer adequado suporte às crianças e às suas famílias em situação de condições clínicas que ameacem ou limitem a vida, visando 
permitir que consigam viver e restaurar sua totalidade. Para tanto, "[...] é a arte e a ciência de fornecer qualidade de vida e atenção a todas as vertentes do sofrimento em crianças criticamente enfermas" (Barbosa et al., 2008, p.128). Podem ser iniciados em diversos pontos da trajetória da doença, lembrando que devem ser começados o mais precocemente possível, sobretudo nas "doenças que limitam a vida", viabilizando o suporte para possibilitar ao filho que viva com a melhor qualidade de vida possível (Bergstraesser, 2012).

$\mathrm{Na}$ área da oncologia, a literatura aponta barreiras específicas que impedem a adequada utilização dos cuidados paliativos para a criança, dentre as quais são mencionadas as seguintes:

- O fato de ser relativamente rara, na faixa etária pediátrica, a morbimortalidade por câncer.

- Os diferentes estágios de desenvolvimento em crianças de 0 a 19 anos.

- A falta de pesquisas baseada em evidências que definam os sintomas e suas causas na criança com câncer, o que afeta sua qualidade de vida durante a trajetória do tratamento curativo da doença e no período de final de vida.

- A falta de tratamentos efetivos para muitos sintomas, especialmente a fadiga.

- A falta de currículos educativos para a formação dos profissionais de saúde que instrumentalizem estas equipes para a implementação de medidas efetivas no intuito de melhorar a qualidade de vida da criança com câncer.

- A falta de investimento financeiro adequado para que o cuidado paliativo possa ser realizado no domicílio do doente (Harrys, 2004).

Muitos especialistas recomendam que o cuidado paliativo seja oferecido a todas as crianças com diagnóstico de câncer (Himelstein et al., 2004) e que este deva ser introduzido desde o momento do diagnóstico, principalmente nos casos em que há baixa probabilidade de cura (Nelson et al., 2000).

Segundo Masera et al. (1999), o Comitê Internacional de Oncologia Pediátrica (SIOP) adverte que a partir do momento que a criança não 
responde com êxito aos tratamentos disponíveis e passa a requerer terapias específicas para desarranjos físicos e mentais, de caráter paliativo e não curativo, esses são fatores que fazem com que os médicos mudem o foco do tratamento de curativo para paliativo. Para os autores, nesse período, o alívio dos sintomas passa a ser prioritário em detrimento da terapêutica curativa, com total inversão de expectativas. Entretanto, quando, e para quem introduzir os cuidados paliativos, ainda permanece controverso entre os oncologistas pediátricos. No entanto, há um consenso de que essa filosofia pode auxiliar o alívio de sintomas na criança com câncer sem possibilidade terapêutica de cura (Himelstein et al., 2004; Bluebond-Langner et al., 2007; Price et al., 2011; Bergstraesser, 2012).

Os achados de estudos sobre a disponibilidade e o uso de serviços de cuidados paliativos e finais de vida em pacientes oncológicos pediátricos, abrangendo serviços de oncologia pediátrica da América do Norte, mostram que a discussão sobre a abordagem paliativa ocorre com maior frequência após a recaída da doença ou quando a terapia já não é mais efetiva; porém, frisa que raramente se aborda a filosofia quando a terapia inicial falha ou mesmo no momento do diagnóstico (Johnston et al., 2008).

Diante disso, importante aspecto ao se disponibilizar o cuidado paliativo é o momento em que isso será discutido com pacientes e suas famílias (Himelstein, 2005; Hutton et al., 2006; Marsella, 2009; Blum e Sherman, 2010). O guidelines da Academia Americana de Pediatria estabelece, para a introdução desta filosofia, a recomendação de um modelo integrado entre elementos curativos e paliativos, oferecido desde o início do diagnóstico e que continue por toda a trajetória da doença, independentemente do resultado final (Nelson et al., 2000; Hutton et al., 2006). A transição deve ocorrer de forma gradual, permeada por comunicação honesta entre profissionais, familiares e pacientes e relacionada aos anseios da família, às necessidades da criança e à compreensão do médico em relação à família e à evolução da doença (Hutton et al., 2006; Kurashima e de Camargo, 2007).

A palavra "transição", entendida como constructo, permite tanto a médicos quanto a provedores de saúde mental preparar crianças e suas 
famílias para a abordagem paliativa, sobretudo por esta ser completamente diferente da abordagem curativa. Se a medicina pudesse reconhecer a fase de transição do cuidado curativo para o paliativo como estágio crítico do tratamento, talvez $\mathrm{o}$ instante em que ocorresse tal mudança pudesse ser menos traumático para todos, crianças e família. Quando a cura já não é mais possível, os provedores de cuidados pediátricos têm como única opção oferecer a esperança para os que sofrem. Essa forma de esperança não foca a cura, mas incorpora o entendimento de que a qualidade de vida não é medida numericamente, pelo comprimento da vida, mas sim pela garantia de que o cuidado compassivo pode ser dispensado em todas as etapas do tratamento (Hutton et al., 2006; Blum e Sherman, 2010).

Estudo de revisão não sistemática da literatura aponta três aspectos que podem complicar a transição para o cuidado paliativo: a natureza intrínseca das transições e seus significados, a falta de tempo para preparar os pacientes e suas famílias e a falta de entendimento dos pacientes e suas famílias sobre os cuidados paliativos (Marsella, 2009), o que se considera determinante para aceitação e preparo da alteração e da meta de cuidado (Barbosa, 2010). Nessa esteira, a introdução dos cuidados paliativos parece ser muito mais do que um processo físico, pois se torna a passagem individual de um conjunto de esperanças para outro (Ronaldsone Devery, 2001; Blum e Sherman,2010; Menezes, 2010).

Pais e equipes de saúde compartilham o desejo de cura das crianças, contudo, em muitas delas, isto não é possível e essa situação pode ser clara já ao diagnóstico da doença e, às vezes, apenas aparente no decurso do tratamento (Harrys, 2004; Hutton et al., 2006; Feudtner et al., 2011).

A decisão de quando o tratamento curativo termina e o cuidado paliativo torna-se exclusivo é crucial para os pais. Estudo demonstrou que a expectativa não real de possibilidade de cura pelos pais, a negação de que 0 filho encontra-se em uma situação terminal e os conflitos familiares são dificuldades quando se pretende utilizar o cuidado paliativo. Tais fatos constituem uma barreira para que os cuidados paliativos possam ser integrados ao tratamento da criança com câncer (Monterosso e Kristjanson, 2008). Por conseguinte, quanto mais precocemente se reconhecer o 
prognóstico da criança sem possibilidade terapêutica de cura, será possível conduzir o tratamento com ênfase no tratamento direcionado à diminuição do sofrimento e maior integração dos cuidados paliativos (Knapp et al., 2010; Bergstraesser, 2012, Vollenbroich et al., 2012).

Deve ser levado em consideração que nesta transição de metas de cuidado, tanto equipe quanto família visam o melhor para a criança. Para cada criança e família, a definição do que se pode considerar como ótima qualidade de vida pode ser diferente e está relacionada ao seu sistema de valores culturais e da realidade médica do diagnóstico (Harrys, 2004; Hutton et al., 2006).

Dessa maneira, a qualidade de vida (QV) é conceito central nos cuidados paliativos e nos cuidados de saúde em geral (Kaasa e Loge, 2003; Bergstraesser, 2012). Uma das concepções destes cuidados é a QV, que deve ser atingida mediante conforto, alívio e controle de sintomas, suporte espiritual e psicossocial e apoio durante o processo de luto. Assim, quando não há mais a possibilidade de cura, a busca pela qualidade de vida no momento de finitude passa a ser o foco de atenção ao paciente. A concepção de qualidade de vida é apontada como algo extremamente importante para paciente e família, sendo o cuidado paliativo apontado como abordagem que possibilita sua melhoria (Silva e Sudigursky, 2008; Matsumoto, 2009; Barbosa, 2010; Kars et al., 2011; Bergstraesser, 2012; Vollenbroich et al., 2012).

A Organização Mundial da Saúde (OMS, 2002) teve papel importante no incentivo dos estudos relacionados à qualidade de vida nas populações na área da saúde quando definiu, em 1947, saúde como:

[...] estado de bem-estar físico, mental e social e não apenas a ausência de doença e enfermidade, estabelecendo assim a característica multidimensional do conceito de saúde e implicitamente relacionando-o à qualidade de vida.

O grupo multicêntrico de estudos de qualidade de vida da Organização Mundial da Saúde (WHOQOL Group, 1998) aponta três características da QV, quais sejam: multidimensionalidade, subjetividade e presença de dimensões positivas e negativas, definindo-a como: 
[...] a percepção do indivíduo acerca de sua posição na vida, de acordo com o contexto cultural e os sistemas de valores nos quais vive e em relação a seus objetivos, expectativas, padrões e preocupações.

Com o aumento da importância desse conceito na área de saúde, o WHOQOL Group desenvolveu definição de qualidade de vida relacionada à saúde (QVRS), devido ao enfoque mais direcionado, voltado, de modo geral, para a percepção da saúde e de seu impacto sobre as dimensões sociais, psicológicas e físicas do indivíduo. Nesse particular, prefere-se usar a QVRS, pelo fato de esta excluir aspectos mais genéricos contemplados na abordagem ampliada de QV, como, por exemplo: rendimentos, liberdade e qualidade do meio ambiente (Minayo et al., 2000; Zanei, 2006).

A grande parte dos estudos com enfoque aos cuidados paliativos pediátricos e famílias refere-se às situações de final de vida e/ou à perspectiva de pais ou familiares que vivenciaram a morte da criança, tendo como foco a população infantil com diagnósticos oncológicos (Lima, 2002; Hinds et al., 2005; Kreicbergs et al., 2007; Valdimarsdóttir et al., 2007; Monterosso e Kristjanson,2008;Dussel et al., 2010; Zelcer, 2010; Zorzo,2010; Price et al., 2011; Kars et al.,2011). Entretanto, já pode ser visto um aumento também na produção de materiais referentes a crianças com "condições que limitam a vida" em cuidados paliativos e o impacto desta situação em suas famílias (Ware e Raval, 2007; Knapp et al., 2010; Menezes, 2010; Rabello e Rodrigues, 2010; Knapp et al., 2011; Schneider et al., 2011; Bousso et al., 2012).

As necessidades de crianças com condições que ameaçam ou limitam a vida e suas famílias são únicas. A carga do cuidado associada à progressão da doença infantil tem profundo efeito em todas as dimensões da vida familiar, afetando as esferas emocional, psicológica, física e financeira. Como resultado, toda estrutura e organização familiar tornam-se permanentemente alteradas, além de gerarem grande influência em seu bem-estar (Contro et al., 2002; Hays et al., 2006; Meyer et al., 2006; Willis, 2007; Monterosso e Kristjanson, 2008; Widger e Picot, 2008; Monterosso et al., 2009; Price et al., 2011; Bergstraesser, 2012).

A família apresenta várias expectativas frente à equipe de saúde, entre as quais se destacam: a necessidade do estabelecimento de vínculo, a 
demonstração de competência e esforço, a troca de informações, a disponibilidade e possibilidade de manutenção de vínculo com sua criança. Portanto, sob sua perspectiva, os programas de cuidados paliativos pediátricos devem ter como foco de ação: comunicação efetiva com familiares e crianças, além de suporte à família nos processos de tomada de decisão e apoio para o manejo da situação irreversível que se instala. Tais medidas são apontadas como pontos necessários para a melhoria dos aspectos da qualidade de vida destas famílias e de suas crianças (Contro et al., 2002; Hays et al., 2006; Knapp et al., 2010; Menezes, 2010; Vollenbroich et al., 2012).

Na filosofia paliativa, reforça-se a relevância da inclusão da família, incluindo o membro doente, no planejamento do cuidado que lhe será prestado nessa fase e que este englobe não só sintomas físicos, mas também os aspectos emocionais, seus valores culturais, éticos e religiosos. Isso constitui um desafio para as equipes de saúde que trabalham com cuidados paliativos, pois agora precisam se despir de sua visão paternalista de detentora do saber e de responsável pela tomada de decisões. Ao inserir o paciente e sua família neste processo, mediante política participativa, a equipe permite que estes proponham intervenções que podem melhorar aspectos da qualidade de vida (Remedi et al., 2009, Bousso et al., 2012; Vollenbroich et al., 2012).

Todavia, isso leva muitos serviços a transferirem a estas famílias especialmente ao cuidador familiar, frequentemente a mãe - os cuidados diários, mas com suporte insuficiente para que a família possa realizá-lo. Cuidar dessas crianças em casa é um trabalho de tempo integral, colocando grande pressão sobre a família. É preciso saber que esforços da equipe também devem ser direcionados para permitir o alívio e a melhora da qualidade de vida de cuidadores familiares, auxiliando-os no enfrentamento da situação de ver e acompanhar um filho em cuidados paliativos. Isto porque, os estudos registram o desgaste físico de quem cuida da criança em cuidados paliativos em domicílio, uma vez que essa tarefa requer cuidados prolongados e complexos, além da sobrecarga gerada pela responsabilidade transferida ao membro familiar que presta assistência domiciliar à criança (Dumont et al., 2006; Monterosso et al., 2007; Knapp et al., 2010; Vollenbroich et al., 2012). 
Nessa fase de cuidados paliativos, os pais precisam de apoio financeiro e emocional para que possam prestar os árduos cuidados que são imprescindíveis para com os filhos que se encontram nesta dolorosa situação. A equipe multiprofissional deve oferecer informações claras e honestas sobre o prognóstico, além de proporcionar às famílias as diretrizes para a realização do cuidado, notadamente para o manejo de sintomas no domicílio (Hsiao et al., 2007; Konrad, 2008; Rabello e Rodrigues, 2010; Vollenbroich et al., 2012). Neste período, outros estudos reforçam a relevância dada pelos familiares ao papel da equipe em auxiliá-los a enfrentar este momento. Além disso, é fundamental haver integração entre o cuidado hospitalar e os recursos de serviços comunitários (Monterosso et al., 2007; Monterosso et al., 2009; Vollenbroich et al., 2012).

No ambiente domiciliar, muitas vezes estes pais necessitam improvisar meios e realizar mudanças estruturais em seu domicílio para poder permanecer com o filho em casa quando este necessita de equipamento especializado para manter seu estado de saúde (Dumont et al., 2006, Rabello e Rodrigues, 2010, Bousso et al., 2012).

O fato de conseguir manter o controle da situação de doença do filho e, com isto, um senso de normalidade da vida familiar é apontado pelos familiares como fator importante para a escolha do cuidado domiciliar (Bousso et al., 2012). Poder optar em ter para si a responsabilidade e poder também participar ativamente do cuidado da criança foram apontados pelos pais como um fator importante. Entretanto, vale ressaltar que isto, em sua opinião, mesmo sendo sua vontade, não ocorre sem preocupações e medo. Por isso, é imprescindível que os enfermeiros reconheçam a ansiedade que os pais desenvolvem durante esta fase, os apoiem e reafirmem os cuidados prestados por eles (Monterosso et al.,2007 e 2009, Price et al., 2011; Bousso et al., 2012).

A literatura disponível corrobora a importância da família quanto ao cuidado da criança em cuidados paliativos. As pesquisas direcionadas à abordagem da questão da qualidade de vida da família no que diz respeito a estes cuidados e suas experiências com relação a ele referem-se, sobretudo, à sua expectativa sobre o cuidado prestado ao filho na etapa final 
de vida. Logo, elas correlacionam sua qualidade de vida com a qualidade do cuidado prestado à criança e seu consequente bem-estar (Contro et al., 2004; Corkin et al., 2006; Hunt et al., 2006; Hutton et al., 2006; Meyer et al., 2006; Hsiao et al., 2007; Monterosso et al., 2007; Willis, 2007; Konrad, 2008; Widger e Picot, 2008; Kars et al., 2010; Price et al., 2011).

Estudo realizado no Canadá comparou a QVRS de pais de crianças submetidas a tratamentos oncológicos com a QVRS da população sadia, a fim de identificar quais eram os indicadores de QV dos pais de criança com câncer, cujos resultados apontaram que quando comparados à população com filhos saudáveis, eles relataram pior QV em todos os domínios psicossociais e na maioria dos domínios de saúde física. Também apresentaram melhor QV quando suas crianças se encontravam com melhor status funcional e em fase de tratamento menos agressivo (Klassen et al., 2008).

Durante o período envidado de esforços aos cuidados, a grande preocupação dos pais passa a ser a busca pela diminuição do sofrimento (Edwards et al., 2008; Knapp et al., 2010). Sob este ponto de vista, o controle da dor é elemento-chave e primeira preocupação das famílias, que precisam se certificar de que todos os esforços despendidos estão sendo realizados para manejar esse sintoma e diminuir o sofrimento da criança (Contro et al., 2002 e 2004; Hays et al., 2006; Monterosso et al., 2007; Kars et al., 2011; Bousso et al., 2012). Eles sabem que quando os sintomas apresentados não são devidamente controlados e quando há 0 distanciamento por parte da equipe no momento da morte, o processo de morte torna-se prolongado e mais difícil de ser assimilado. Na visão dos pais, o controle da dor e dos demais sintomas é substancial no momento final de vida. Se os profissionais da área de saúde conseguissem compreender isso, por meio do controle eficaz dessa sintomatologia, proporcionar-lhes-ia a diminuição da angústia e os ajudariam a enfrentar a fase de luto (Lima, 2002; Kreicbergs et al., 2005; deCinque et al., 2006; McCarthy et al.2010; Zorzo, 2010).

Tal fato é comprovado e complementado por trabalho realizado nos Estados Unidos, onde foram entrevistados 36 pais de crianças com doenças 
limitantes de vida. Os resultados encontrados reforçam que uma das preocupações recorrentes destes familiares está voltada para que a criança receba o cuidado de forma contínua e coordenada durante o curso da doença e o processo de morte. Eles apontam isto como especialmente importante para sentir que os seus filhos receberam o melhor cuidado possível que poderiam ter-lhes ofertado naquele momento, tendo a sensação de que seu papel fora cumprido de forma satisfatória no decorrer ao tratamento. Quando isso não acontece, eles se frustram e se tornam mais vigilantes, porque passam a desconfiar da equipe e do cuidado que vem sendo prestado. Além disso, percebem, ainda, que manter o relacionamento com a equipe é a chave para garantir que pais e filhos estão sendo cuidados satisfatoriamente por estes profissionais. Como consequência, sentem-se confortáveis e seguros no ambiente hospitalar, com forças para tentarem manter a vida mais próximo possível do normal, mesmo após a morte da criança (Heller e Solomon, 2005).

Diante de todo esse cenário, vale registrar, ainda, que, nessa fase, não são somente as crianças que enfrentam deterioração de suas condições físicas, mas também os familiares, que sofrem desgaste físico e sofrimento emocional consideráveis. $\mathrm{O}$ diagnóstico de uma recidiva da doença ou de sua disseminação pelo corpo da criança são fatores que proporcionam aos pais a conscientização de que as intervenções médicas estão ficando limitadas e que podem estar frente à aproximação da morte do filho (Lima, 2002). Os pais reconhecem prontamente os sintomas físicos, decorrentes da piora clínica, apresentados pela criança em fase terminal, mas somente se asseguram da impossibilidade de cura do filho e sua morte iminente nos dias que realmente antecedem a sua morte. Nesse período, conseguem perceber e integrar os cuidados paliativos em sua rotina, relacionando-os diretamente à diminuição do sofrimento que presenciam (Wolfe et al., 2000b; Kars et al., 2010; Bousso et al., 2012).

Bousso et al. (2012), ao estudar o manejo familiar no contexto dos cuidados paliativos pediátricos, coloca que as famílias sabem que estão num processo de transição entre ter o filho vivo e com os sintomas controlados e não ter mais o filho fisicamente presente na família e que a 
forma como ela se ajusta ou não, às variações do estado clinico da criança, está influenciada pelo apoio social recebido, seu conjunto e crenças e a forma como definem a doença e a criança.

A progressão da doença e a aproximação da morte exigirão cuidados com a intenção de minimizar ou evitar o sofrimento. Tal processo pode ocorrer no hospital ou no domicílio, o que dependerá da vontade da criança e da família, da disponibilidade de recursos dos serviços de saúde, da capacidade e da habilidade dos pais para o cuidado, além das estruturas de apoio (Lima, 2002; Vickers et al., 2007; Zorzo, 2010; Price et al., 2011). Os pais expressam alívio quando o desejo de permanecer no domicílio em fase terminal de doença é compartilhado pelo filho e percebem o ambiente hospitalar como um lugar estressante para a sua criança morrer devido ao barulho e à falta de privacidade (Zelcer et al.,2010).

Ao perceberem a progressão da doença, com o contínuo aumento do sofrimento do filho, não obstante os esforços da equipe em controlar a sintomatologia e da perda da capacidade da criança em se comunicar, concluem, neste momento, que, apesar de seu próprio sofrimento, a morte do filho poderá ser a melhor resolução para ele (Hunt et al., 2006; Kars et al., 2010 e 2011).

Para as mães que se deparam com os filhos em situação de final de vida, a competência na comunicação e no relacionamento interpessoal com a equipe é o que mais influencia em sua avaliação com relação aos profissionais de saúde. Isto porque, segundo elas, a equipe com experiência em cuidados de final de vida lhes proporcionou grande suporte no período em que vivenciaram o árduo processo terminal do filho. Assim, reforça-se a importância e necessidade de se ter um profissional treinado nesse contexto para dar o suporte necessário solicitado por estas famílias (Konrad, 2008). Esta carência familiar é reforçada em outros estudos, que colocam a importância de se realizarem processos educacionais constantes dos profissionais. Para isso, recomendam que isto seja feito mediante elaboração de guidelines (Monterosso et al., 2007; McCarthy et al., 2010).

Os estudos trazem, ainda, aspectos relacionados ao momento da morte da criança que podem estar relacionados à alteração da qualidade de 
vida dessas famílias (Hinds et al., 2005; Kreicbergs et al., 2005; Hunt et al., 2006; Dussel et al., 2009). Isso porque o cuidado da criança nos instantes finais de vida é um dos focos principais do processo de cuidados paliativos (Hinds et al., 2005). Bousso (2006, p. 136) afirma que a morte do filho é mais que um processo biológico, pois abrange aspectos cognitivos e emocionais, uma vez que a experiência da morte e do luto obriga a família a construir nova realidade, em que a maior transformação é "[...] ter uma criança que viverá uma vida longa, para ter uma criança que está morrendo ou que já está morta". Logo, reduzir o sofrimento dos pais nessa etapa final pode ser um caminho significativo para contribuir para o futuro bem-estar deles e do restante da família (Pritchard et al., 2008).

No tocante às decisões a serem tomadas na fase dos cuidados paliativos, estudo realizado nos Estados Unidos - envolvendo 39 pais de crianças que faleceram com câncer, 16 médicos, três enfermeiras e dois capelães - demonstrou que, para os profissionais de saúde, respeitar as preferências do paciente e da família e concluir que ele não sobreviveria foram os fatores que mais influenciaram em sua tomada de decisão. Por certo, para eles, decisões de manter ou tirar o suporte de vida, realizar quimioterapia paliativa ou não e optar entre a ordem de ressuscitar ou não em situação de parada cardiorrespiratória são difíceis de serem tomadas. Foi possível identificar nas falas destes pais fatores que influenciaram em sua tomada de decisão, como o tipo de informação que receberam dos profissionais de saúde, que incluiu explicações e opiniões sobre a doença, as habilidades funcionais, o prognóstico e a exigência de um cuidado continuado (Hinds et al., 2001; Dussel et al., 2010; Price et al., 2011).

A perda do filho é um fenômeno traumático e estudo sobre as necessidades de pais enlutados, na perspectiva destes, mostra que eles mencionam a necessidade de manter o contato com a equipe profissional após a morte, justificando que são pessoas que tiveram contato com sua criança e, por isso, entendem o que vivenciaram naquele momento. Poder conversar com outros pais que passaram por experiências semelhantes também foi identificado como um fator de extrema relevância. De acordo com estes pais, tais necessidades poderiam ser atingidas por meio de 
serviços especializados para o acompanhamento do luto. No referido trabalho, $60 \%$ dos pais entrevistados declararam ter usado o serviço para seguimento do luto oferecido na sua comunidade e, destes, 67\% acreditam que isto os ajudou a enfrentar a situação de perda. Por essa razão, a existência de serviços de seguimento do luto poderia facilitar a sua elaboração de luto e melhorar sua qualidade de vida, no sentido de auxiliálos a reencontrar a possibilidade de continuar vivendo, além de possibilitar que haja a transição gradual destes serviços hospitalares para o ambiente comunitário (D'Agostino et al., 2008).

Estudo que teve como objetivo explorar a experiência e necessidade de pais cujas crianças morreram de câncer, atendidos por um serviço de luto, aponta como necessidades destes pais, durante este período, temáticas relacionadas ao luto pessoal, suas estratégias de enfrentamento, a preocupação com os irmãos da criança que morreu e o apoio recebido pelo grupo de suporte hospitalar e da comunidade. Na perspectiva destes familiares, a necessidade de maior contato com a equipe durante a fase de cuidados paliativos e o processo de morte, além da possibilidade de receber informações sobre a proximidade da perda da criança os preparam emocionalmente para enfrentarem a penosa fase terminal (deCinque et al., 2006).

Neste sentido, os irmãos das crianças falecidas não devem ser esquecidos, cabendo aos pais a responsabilidade e conscientização de garantirem e estenderem também o suporte para eles. Ressaltam que reconhecem que estes também são emocionalmente afetados pela doença e morte do irmão e tentam não passar para os filhos sadios a carga de terem de cuidar da criança doente, encorajando-os a manter um estilo de vida normal tanto quanto seja possível (Monterosso et al., 2007; Price et al., 2011).

A situação de morte não é fácil de ser trabalhada e enfrentada, tendo em vista que é extremamente dolorosa, dado que se percebe a injustiça da doença e a não possibilidade de futuro. Enfrentar a realidade mediante intervenções que possam aliviar a dor e o sofrimento pode ser uma importante forma de tornar esse contexto menos ameaçador tanto para o doente, quanto para a sua família e para a equipe de saúde, esta 
inevitavelmente engajada nos cuidados prestados. Quando a equipe de saúde, os familiares e amigos demonstram à criança e ao adolescente, em todas as fases do processo diagnóstico e terapêutico, que eles continuam sendo amados, que não serão abandonados e tampouco se sentirão sozinhos revelam atitudes que se desdobram em um significado positivo à condição de terminalidade. Mesmo diante da complexidade de cuidar do adolescente com câncer, sobretudo na fase paliativa, os profissionais, com compaixão e solidariedade, podem reduzir o impacto da doença e proporcionar alívio do sofrimento, possibilitando a construção de novas perspectivas para que as intercorrências cotidianas possam ser vencidas (Remedi et al., 2009).

Rallison e Moules (2004) apontam a importância de estudos na área de cuidados paliativos pediátricos. Para as autoras, esta área retrata a natureza do "inexprimível", do "não falado" na área da saúde, transformando o cuidado em uma prática silenciosa. É difícil aceitar a ideia de que a criança carece de cuidados paliativos. O seu falecimento não está previsto nos planos familiares. A magnitude desta possível perda tem efeito também na comunidade, na escola, na vizinhança e nos profissionais de saúde, silenciando a criança e a família nesta fase de profundo sofrimento.

Dessa forma o presente estudo se propõe a compreender a experiência da família da criança que está em cuidados paliativos. Sem uma compreensão clara sobre o significado que a família dá à experiência de ter um filho em cuidados paliativos e como interpreta e define a situação, pouco pode ser realizado para promover o processo de cuidar e do morrer nessa perspectiva. Desta feita, esse estudo visa a contribuir para ampliar a compreensão desse processo de cuidar, permitindo avançar na postulação de um quadro teórico que contemple a integração de saberes e de ações que constituam assistência integral transcendendo 0 atendimento de necessidades apenas clínicas e biológicas nas situações que envolvem o cuidado da criança em cuidados paliativos e sua família. 
2 Objetivos 


\subsection{Objetivo Geral}

Compreender a experiência da família da criança/adolescente em cuidados paliativos.

\subsection{Objetivos Específicos}

a) Identificar os significados que a família atribui ao processo de ter uma criança/adolescente em cuidados paliativos.

b) Identificar as ações e estratégias desenvolvidas pela família que possui uma criança/adolescente em cuidados paliativos.

c) Construir um modelo teórico representativo do processo da família em vivenciar a trajetória de uma criança/adolescente em cuidados paliativos. 
3 Metodologia 


\subsection{A Pesquisa Qualitativa}

Com relação a este tipo de pesquisa, Denzin e Lincoln (2006) assim a definem: "[...] é uma atividade situada que localiza o observador no mundo[...]". Isto significa que consiste em um conjunto de práticas materiais e interpretativas que proporcionam visibilidade ao mundo.

A pesquisa qualitativa investiga a vida das pessoas, suas experiências, ações, pensamentos, emoções e sentimentos (interações autodirigidas e também em relação aos outros). Além disso, examina e observa minuciosamente o funcionamento de organizações, tais como: serviços de saúde, movimentos sociais, fenômenos culturais e interação entre nações (Strauss e Corbin, 2008).

Apesar de os métodos qualitativos possuírem procedimentos comuns, eles apresentam, individualmente, estratégias e técnicas analíticas peculiares, adotando uma perspectiva única. A escolha por um deles deve levar em conta os propósitos e as questões da pesquisa (Morse e Richards, 2002).

A natureza das questões do presente estudo reflete o interesse em compreender processos e mudanças ao longo do tempo. O que significa para a família ter uma criança/adolescente em cuidados paliativos? Como se dá o processo de cuidar destas crianças/adolescentes pela percepção da família? Como a família maneja a situação de ter um filho em cuidados paliativos?

Esse estudo de abordagem qualitativa fez uso do Interacionismo Simbólico como referencial teórico e a Teoria Fundamentada nos Dados como referencial metodológico para compreender a experiência da família da criança/adolescente em cuidados paliativos, identificando os significados atribuídos por ela à experiência. 


\subsection{O Interacionismo Simbólico Como Referencial Teórico}

A escolha deste referencial teórico relaciona-se à viabilidade de se compreender eventos. Para Blumer (1969), referidos eventos são as situações encontradas a partir da interação dos seres humanos, o que se relaciona à compreensão que eles são capazes de formar a partir das relações que estabelecem, incluindo as denominações usadas durante a convivência social. $O$ presente estudo tem por fim compreender a experiência da família da criança/adolescente em cuidados paliativos.

O Interacionismo Simbólico restringe-se ao estudo dos comportamentos humanos individual e grupal. Além disso, abrange a questão vivencial, ou seja, como os indivíduos definem os eventos ou a realidade e qual a atitude deles quanto às suas definições. Este tipo de Interacionismo tem por fim entender a causa da ação humana, a sua definição, autodireção e escolha nas situações. Neste particular, parte da ação humana é escolha, sendo assim livre (Charon, 2004). O Interacionismo Simbólico foi reconhecido por estudiosos de família como uma teoria útil para se compreender os fenômenos familiares (Burr et al., 1979; Nadeau, 1998; Rosenblatt, 2000; Bousso, 2006).

O Interacionismo Simbólico elegeu-se como perspectiva teórica para sustentar o desenvolvimento do estudo, nortear o pensamento e compreensão sobre os fenômenos, processos e padrões de interação familiar. Estes aspectos são compatíveis com a abordagem qualitativa de pesquisa com família (Ângelo et al., 2010), quando se busca entender o seu funcionamento interno e a essência da vida, construída mediante o significado.

Para Blumer (1969, p. 21), o Interacionismo Simbólico "[...] fornece as premissas para uma profunda filosofia com características fortemente humanistas". Para esta filosofia, o alcance da interação humana acontece quando se reconhece que a formação e realização do self do indivíduo acontecem na aproximação e no papel diante dos "outros"; são aqueles com quem o indivíduo desenvolve atividades em conjunto, como grupos aos quais pertence, trabalho e sociedade.

Charon (2007, p. 29), ao descrever o termo, seguindo a mesma linha de Blumer (1969), assegura que o Interacionismo Simbólico "[...] envolve as questões importantes que são utilizadas por aqueles que se esforçam em 
identificar o que o ser humano é, e porque ele age de uma determinada maneira ou de outra". Desta feita, o indivíduo tem de ser visto como agente e participante de suas experiências. É impossível entender a posição ou como o evento/ fenômeno se dá sob o ponto de vista descritivo. O ser humano está sempre em relação com o que convive. É por isso que não se pode explorar somente uma causa para o evento, tendo em vista que as ações, decisões e preferências são interações que fazem parte da relação de uma pessoa com as outras.

O Interacionismo Simbólico tem suas origens na Psicologia Social; todavia, ao invés de focar o indivíduo e suas características de personalidade ou a influência da situação social sobre o seu comportamento, como acontece na Psicologia e Sociologia, o Interacionismo Simbólico concentra-se na natureza das interações, na dinâmica das atividades sociais entre os indivíduos, nos significados que eles atribuem aos eventos vividos, nos ambientes naturais em que vivem e nas ações que desempenham (Charon, 2004).

O Interacionismo Simbólico foi desenvolvido a partir dos trabalhos de George Herbert Mead e Herbert Blumer, para o qual, este referencial teórico tornou-se "[...] um rótulo para abordar de maneira relativamente distinta os estudos envolvendo a vida ou as ações de grupos humanos." (1969, p. 1). O Interacionismo é uma ciência interpretativa, uma teoria psicológica e social, cujo objetivo é procurar entender o processo de criação e atribuição de significado que os humanos dão à realidade. De acordo com Charon (2007), o pesquisador deve direcionar a sua atenção para o dia a dia, onde as situações são vivenciadas. Os autores dão ênfase à ação prática, nas quais as pessoas estabelecem um modo de negociar entre si, para viver em conjunto com outras. Esse referencial teórico viabiliza explorar as interações entre as partes, mas sempre percebidas sob o aspecto social.

Como dito anteriormente, o aparecimento das ideias iniciais desse referencial é atribuído a George Herbet Mead, professor de filosofia da Universidade de Chicago, que formatou as bases ideológicas da interação simbólica. As formas teórica e metodológica foram descritas por um aluno seu, Herbert Blumer, e têm sido, ao longo dos anos, amplamente aplicadas nas universidades de Chicago e Berkeley e aprimoradas em diferentes trabalhos de pesquisa em vários países (Charon, 2007). 
Charon (2007) garante que Mead define as bases do Interacionismo Simbólico utilizando os fundamentos básicos do pragmatismo, provenientes da psicologia, e teve influência das teorias de Charles Darwin e das bases behavioristas. Destarte, o pragmatismo é considerado um eixo fundamental para este referencial, pois procura compreender como as pessoas se relacionam com o ambiente em que vivem, dado que elas podem alterar fatos que pertencem à sua vida.

$\mathrm{Na}$ opinião de Strauss e Corbin (2008), o pragmatismo não se compõe da ação humana, mas sim do resultado do pensamento do indivíduo sobre a ação. O que faz parte de sua vivência e com aquilo que ele se relaciona são reconhecidos e enfrentados a partir de um dado momento de sua vida. As ações para enfrentá-los ou resolvê-los são definidas em relação aos resultados esperados. Qualquer atividade de pensamento realizada sem a reflexão sobre a sua condução antes de adotá-la conserva seus aspectos temporais. Os aspectos de uma ação estão relatados aos de outra, delimitados pela percepção de quem a realizou. O pragmatismo reforça, pois, a ideia da acumulação do conhecimento coletivo, mantendo as características do contexto e da ação.

Tanto as ações quanto as interações são responsáveis em desenhar o fenômeno. Na visão de Strauss e Corbin (2008), pelo fato de o mundo ser complexo em virtude de existirem ambiguidades, períodos de alterações e estabilizações, as situações rotineiras podem se transformar em problemas no futuro, as respostas em questionamentos e estes em respostas resultantes da ação e reação.

De acordo com Blumer (1969), são três as premissas básicas do Interacionismo Simbólico:

1. Os seres humanos agem em relação às "coisas" com base no significado que elas têm para eles, sendo "coisas" tudo o que podem observar em seu mundo: objetos físicos, pessoas com que convivem ou se relacionam posições que os indivíduos possuem em dado contexto, atividades, instituições, o guia de ideias, tais como: independência individual ou honestidade, atividades dos outros como mandos ou comandos e situações da vida cotidiana enfim tudo e todos que fazem relação ou que demandam sua posição ou resposta. Cada ser humano atribui a essas "coisas" seu próprio significado. 
2. O significado das coisas é derivado da interação social ou da convivência que o ser humano estabelece com outras pessoas e não é nem inerente à coisa em si, nem uma união de elementos psicológicos que o indivíduo tem em relação a ela. O Interacionismo Simbólico interpreta os significados como produtos sociais definidos na interação.

3. Os significados são manipulados e modificados por intermédio de um processo interpretativo usado pelo ser humano quando lida com as coisas que encontra. Tal processo possui duas fases distintivas. Na primeira, o indivíduo indica para si mesmo as coisas às quais lê, e dá a elas um significado. $O$ fazer de tais indicações é um processo social internalizado, no qual ele interage consigo mesmo; na segunda fase, o ator (indivíduo), pelo processo de comunicação consigo mesmo, faz a interpretação tornar-se uma questão de lidar com significados à luz da situação na qual ele se encontra. Dessa forma, a interpretação não é considerada como uma mera aplicação automática de significados estabelecidos, mas como um processo formativo no qual eles são usados e revisados como instrumento para guiar e formar a ação, fazendo sua parte nela por meio de um processo de auto-interação.

A perspectiva do Interacionismo Simbólico parte do princípio de que a conduta humana deve ser basicamente compreendida em termos sociais. A dimensão social não é entendida como mera influência externa do indivíduo. A descrição do comportamento humano é fundamentada no ato social.

A definição da situação refere-se ao significado subjetivo que uma situação particular tem para o indivíduo. De acordo com Charon (2004), pessoas diferentes que vivenciam a mesma situação podem defini-la cada uma de uma forma. Além desse enfoque, a forma de o indivíduo definir a situação determina os efeitos dessa situação na própria vida. Nada possui significado intrínseco ou valor inerente. O significado é criado pela experiência, pelas pessoas, o que leva à ação e suas consequências. É por meio da interação com o objeto e com nós mesmos que esse é definido.

O pressuposto de definição da situação foi avaliado nas reações de estresse vivenciadas pela família por Burr et al. (1979). A definição que a família dá à gravidade de eventos estressantes influencia o impacto que os eventos tendem a ter para a pessoa. Segundo os autores, "[...] a definição da situação influencia o efeito daquela situação de tal forma, que os efeitos tendem a ser coerentes com a definição". Portanto, as definições não provêm de um vácuo. É importante conhecer como as definições das situações são influenciadas pelos outros. 
Para o Interacionismo Simbólico, o ser humano é um ator, os atos humanos simbólicos, e as interações são um processo psicossocial básico. Por meio desse processo é que a personalidade e a sociedade emergem, expressam-se e se perpetuam. Logo, o ser humano é entendido como um ser social, interativo e simbólico por natureza.

O Interacionismo Simbólico reúne os seguintes conceitos fundamentais: símbolo, self, mente, assumir o papel do outro, ação humana e interação social e sociedade, os quais são descritos, sucintamente, a seguir, com base em Charon (2004).

\section{- Símbolo}

Segundo o Interacionismo Simbólico, símbolo é o conceito central, sem ele, não se pode interagir com os outros. Eles são importantes quanto ao entendimento da conduta humana. O indivíduo vive com símbolos tão bem quanto com o meio físico, ele se utiliza do símbolo intencionalmente, com o propósito de dar significado; ele aprende símbolos, seus significados e valores, de outras pessoas, com quem interage. Este conjunto de significados e valores é parte de um conjunto da cultura do grupo. Assim, os símbolos são uma classe de objetos sociais usados pela pessoa para representar e comunicar alguma coisa aos outros e a si.

O significado não é intrínseco ao objeto. Damos nome aos objetos, aprendemos para que servem e como são usados, mas eles são definidos pelas pessoas envolvidas em uma situação de acordo com o seu uso. Por exemplo, uma flor pode ser dada a quem se ama, enviada a uma pessoa em luto e usada para decorar a casa, entre outras. Por esta razão, na perspectiva do Interacionismo Simbólico, os objetos são sociais: mediante interações, aprende-se o significado das coisas.

Como os objetos sociais, os símbolos são usados e definidos de acordo com o seu uso. Objetos sociais que não são usados para representar alguma coisa não são considerados símbolos, tendo em vista que todo símbolo é um objeto social, mas nem todo objeto social é um símbolo. Um coração é simplesmente um objeto social, mas, quando utilizado para representar ou comunicar amor, compaixão, torna-se um símbolo. É por 
meio dos símbolos que a pessoa se comunica consigo, com os demais outros seres humanos e interpreta a comunicação de outros.

Os símbolos são sociais, pois são definidos na interação. Alguns deles são convencionais, pois representam coisas acordadas por pessoas quanto aos seus significados. As campanhas de doação de órgãos, por exemplo, utilizam-se da figura do coração para representar o ato de amor e compaixão por este ato.

Palavras fazem parte da linguagem, que é um tipo especial de símbolo, pois podem representar a realidade, ao contrário de outros símbolos. Não só as palavras são símbolos, mas sem elas outros símbolos não existiriam, pois não poderiam ser descritos. Todo ato e objeto simbólico têm significado, porque pode ser descrito pelas palavras. Desse modo, a linguagem é um sistema simbólico, definido na interação e usado para descrever o que se observa, se pensa e se imagina (Charon, 2004).

No contexto da presente pesquisa, "cuidado paliativo" é um símbolo e é na interação entre a criança/adolescente em cuidados paliativos e a família, na interação entre os membros da família e dela com a equipe que surge o significado de "cuidado paliativo".

Por meio da comunicação dos símbolos, os indivíduos podem aprender vários valores e significados. Esta aprendizagem também se dá dentro do contexto familiar. Para que se possa identificar a definição que a pessoa dá, é importante conhecer a percepção do outro generalizado e dos outros significantes. Outro símbolo importante da linguagem e que traz um significado à experiência da família é o termo "doença incurável". Os valores e significados dados pela família à "doença incurável" são fortemente influenciados pelos outros generalizados, ou seja, pelas interações com a sociedade.

Berger e Luckmann (2004) identificam linguagem como o veículo mais importante para a manutenção da realidade. Na descrição das formas de como a conversa mantém a realidade, eles se aproximam da descrição do processo interativo no qual os membros da família podem encontrar sentido para suas experiências. Sugerem que o dia a dia do indivíduo pode ser visto como o trabalho ausente de uma conversação que continuamente mantém, modifica e reconstrói uma realidade subjetiva. 
Perspectivas são grupos de símbolos. De acordo com essa estrutura simbólica, abordamos e vemos a realidade. Nossos símbolos são, portanto, guias para o que vemos, interpretamos, assim como para aquilo que deixamos de perceber em uma dada situação. A interação humana faz surgir objetos sociais, símbolos, linguagem e perspectivas que levam à interpretação de uma situação e, finalmente, à ação (Charon, 2004).

Pensar a família interacionalmente leva-nos a buscar os significados que ela dá aos objetos sociais, símbolos, palavras e perspectivas diante das interações que aparecem na experiência de ter um filho em cuidados paliativos e se deparar com a necessidade de seguir cuidando e vivendo, mesmo que saiba que a morte do filho possa ser inevitável.

Entende-se, pois, que a realidade é socialmente definida, mas que a definição está sempre personificada, influenciada pelo indivíduo e pelos grupos sociais. As famílias podem ser construídas como pequenos grupos que socialmente criam suas próprias realidades.

Berger e Luckmann (2004) identificaram múltiplas realidades. Os autores tratam das realidades do dia a dia como realidades dominantes, nas quais as realidades marginais precisam ser integradas. A morte foi identificada como a mais importante das realidades marginais.

Self

O Interacionismo Simbólico considera que o ser humano apresenta um self, isto é, assim como o indivíduo age socialmente em relação aos demais, ele interage socialmente consigo.

O self é, portanto, um objeto social, surge na interação, sofrendo mudanças ou permanecendo estável na interação. O seu significado é a pessoa estar apta para se ver como objeto. $O$ indivíduo consegue se olhar, como faz com qualquer outro objeto social. A importância do conceito relaciona-se a todo o processo de interação interna do indivíduo em relação a si, como identidade, percepção e julgamento de si. Tais ações são denominadas comunicação simbólica e tornam possíveis as demais. Charon (2004) registra que o self representa um processo social interiorizado no indivíduo e apresenta duas faces: Eu e Mim. 
O Eu é a resposta do organismo às atitudes dos outros, é o indivíduo como sujeito, é espontâneo, não se sujeita às regras socialmente estabelecidas. O Mim são atitudes organizadas que o indivíduo adota, fruto da interiorização da sociedade, constitui a pessoa como objeto. O Mim é o self social, o objeto que surge da interação, cuja ação é norteada pelas definições e expectativas dos outros que cercam o indivíduo. Neste sentido, o Eu impulsiona o indivíduo e o Mim representa a incorporação do outro no indivíduo. Assim sendo, toda a ação começa impulsionada pelo Eu, o Mim direciona $o$ ato.

A importância desse conceito para os estudos de famílias que vivenciam os cuidados paliativos do filho é que o self é social: os seus membros se conhecem por meio de outros integrantes seus e dos outros significantes fora dela. A maneira como os demais agem em relação a nós define nosso self. Como os membros familiares definem seu self nesta experiência, a partir destes referenciais, é possível compreender o que impulsiona e o que direciona as suas ações.

O ser humano pode comunicar-se consigo e, por isso, é tanto sujeito como objeto da comunicação. Graças ao self, ele pensa, aponta coisas a si e interpreta situações. Como os integrantes da família interpretam a realidade de ter uma criança/adolescente em cuidados paliativos? O que pensam? Quais reflexões fazem a respeito deste tipo de cuidados nesta experiência presente?

O self é a base utilizada pela pessoa para fazer julgamentos, como pensar nos prós e contras dos cuidados paliativos e planejar a ação a ser adotada em relação a outros objetos que surgem nas situações que vivencia (aliviar o sofrimento, familiares, amigos, processo de morte e morrer). $\mathrm{O}$ autojulgamento essencialmente resulta do julgamento que pessoas importantes e grupos de referência fazem sobre nós. No entanto, o mais importante é a autopercepção desse julgamento.

A essência do self é a possibilidade de estabelecer uma comunicação com nós mesmos, o que, por sua vez, nos permite perceber o self e conduzilo, dando ordens a nós mesmos. Portanto, a importância deste conceito diz respeito à possibilidade de exploração do processo de interação interna do 
indivíduo. Ele nos aproxima da comunicação que se estabelece da pessoa com ela mesma, os julgamentos e ordens que surgem no self.

Dizer que o self muda na interação com os outros equivale a dizer que os atos também se modificam (Charon, 2004). Diante de um evento importante, como a notícia de que o filho é portador de uma doença sem possibilidade terapêutica de cura e até mesmo de sua morte, o indivíduo perde sua definição do self e das situações do cotidiano que ocorriam com aquela pessoa. Nesse caso, o familiar precisa redefinir a situação e os significados relacionados ao processo de ter uma criança/adolescente em cuidados paliativos.

Ao se utilizar do Interacionismo Simbólico no trabalho com famílias que vivenciam a morte de um de seus membros, é possível identificar significados que a definem e outros que igualmente refletem novas definições de self (Rosenblatt, 2000).

\section{Mente}

A mente resulta da interação social, instrumentalizada pelo cérebro humano. Conforme Charon (2004), é a sociedade - a interação social -, usando cérebros, que faz a mente.

De acordo com Mead (1972), o cérebro permite ao indivíduo exercer domínio consciente de sua conduta. É a simbolização que possibilita a conduta mentalmente controlada, a partir da indicação de que o indivíduo faz a si e aos outros na situação.

Para Charon (2004), a mente é definida como ação simbólica em relação ao self, devendo ser vista como atividade; ela é uma comunicação ativa com o self pela manipulação dos símbolos. Significa que o indivíduo faz indicações para si, pela atividade mental (pensar), atribui significados, interpreta, dando sentido às coisas em relação àquela situação ou ao fato vivenciado. A ação, então, é resposta decorrente da interpretação que o indivíduo fez e não uma resposta reflexa ao objeto (coisa). Quando vivenciadas determinadas situações, determina-se aquilo que nelas é importante para nós e a definimos: isto é atividade mental.

Uma das ideias do Interacionismo Simbólico é apresentada por Charon (2004) a partir dos trabalhos de Mead e Blumer da seguinte forma: 
Interação não é simplesmente o que está acontecendo entre pessoas, mas também o que está ocorrendo no íntimo do indivíduo. Os seres humanos agem num mundo definido por eles. Nós agimos de acordo com a maneira como definimos a situação em que nos encontramos.

A mente possibilita desenvolver uma linha de ação ou ensaiar este ato. Sem isto e sem ensaiar atos, os seres humanos estariam limitados a responder aos objetos que aparecem diante deles.

A família que possui uma criança/adolescente em cuidados paliativos faz as próprias indicações pela atividade mental, pelo pensamento e atribui significados, interpreta e dá sentido às situações envolvidas na experiência.

O atraso na resposta, a consideração de estratégias de ação, a definição e redefinição ativa dos objetos são atividades básicas da mente, que é toda comunicação dirigida ao self sobre o mundo externo e ao objeto dentro de cada pessoa, o self.

É preciso definir as situações sociais e atribuir significado às palavras das outras pessoas, à medida que são proferidas; seus atos e intenções devem ser interpretados e é isto que a família faz ao ser informada pela equipe de saúde que o filho está em cuidados paliativos. Para entender o outro na situação (médico), é necessário estar engajado em atividade mental (conversa com o self) e, obrigatoriamente, com os outros (médicos, familiares e demais significantes).

Um aspecto relevante sobre este conceito para o presente trabalho é que a atividade chamada de mental torna-se mais deliberada e consciente quando nos defrontamos com uma situação-problema. Embora tenhamos atividade mental o dia inteiro, praticamente sem percebê-lo, diante de uma situação difícil, ou problema a ser resolvido, essa atividade torna-se mais consciente. Uma contingência interrompe o fluxo de ação e pensamos como resolvê-lo. Nós redefinimos o que consideramos certo, começamos a anotar de coisas, analisamos nossos recursos e fazemos um balanço da situação e do nosso self em relação àquela situação (Charon, 1989).

O contexto dos cuidados paliativos é constituído por uma situação de crise e, conforme Berger e Luckmann (2004), a integração requer procedimentos diferentes daqueles utilizados para integrar outras realidades do dia a dia. Os procedimentos para a manutenção da realidade em 
situações de crises precisam ser mais explícitos e intensos do que os necessários para integrar realidades supremas.

Algumas vezes, em situações de crises, os rituais são trazidos para 0 cenário e podem ser improvisados pelos indivíduos, mas, geralmente, são configurados pela sociedade, que reconhece o risco da quebra da realidade nestas situações (Berger e Luckmann, 2004).

Assumir o papel do outro

O conceito está inteiramente ligado aos anteriores. Assumir o papel do outro é uma atividade mental importante, tornando possível o desenvolvimento do self, a aquisição e o uso de símbolos e a própria atividade mental. No entender de Charon (2004), "[...] é pela mente que os indivíduos entendem o significado das palavras e ações das outras pessoas".

Ao assumir o papel do outro, o indivíduo busca uma explicação à ação que observa e, em consequentemente, alinha sua ação à razão identificada. Por conseguinte, este conceito é considerado como condição à comunicação e interação simbólica.

A importância deste conceito para a pesquisa deste estudo reside na compreensão da atividade mental realizada pelos membros da família diante da realidade de ter uma criança/adolescente em cuidados paliativos. Assumir o papel do outro permite que a família se coloque no lugar da criança/adolescente para compreender como é vivenciar o contexto de perdas e sofrimento decorrentes da progressão da doença, compreendendo melhor suas expectativas e necessidades. Desse modo, colocar-se no lugar dela ajuda o familiar a ressignificar os cuidados paliativos e reconhecê-los como uma opção de cuidado que corresponda às novas expectativas e necessidades de sua criança/adolescente.

\section{Ação humana}

A capacidade que o ser humano possui de fazer indicações para si proporciona uma característica à ação humana; significa que o indivíduo confronta-se com o mundo que deve interpretar, a fim de agir. Ele precisa 
lidar com a situação para a qual é chamado a agir, investigar o significado das ações dos outros e definir sua própria linha de ação à luz da interpretação. Pelo processo de autointeração, o indivíduo manipula seu mundo e constrói sua ação (Blumer, 1969).

A ação humana diz respeito ao indivíduo que a realiza por ser um processo simbolicamente construído, ela é um fluxo contínuo que segue determinada direção. É um processo contínuo, porque um ato leva ao outro. As ações e seu fluxo mudam constantemente de direção e, como seres humanos, somos ativos no processo de direcionar o curso da ação.

Frente às novas situações e à entrada de fatores igualmente novos em nossas vidas, como ter um filho em cuidados paliativos, pode-se mudar a direção das ações. Como a direção do fluxo delas depende das decisões que se toma ao longo desse fluxo, sua mudança de direção depende também de nossas decisões. Por conseguinte, nossas decisões dependem da interação com outras pessoas e com o self. Desse modo, a interação com o self e com os outros leva o indivíduo a tomar decisões que direcionam o curso da ação. Assim, a definição que a pessoa faz determinará como a ação ocorrerá, podendo ela ser tanto aberta, como encoberta, pois seu curso envolve um processo contínuo de definição e redefinição da situação (Charon, 2004).

O que influencia as decisões tomadas em uma dada situação são nossas definições das mesmas. Assim, ao longo de ações, a família define metas, problemas, objetos sociais e, então, resolve como agir. Toda ação aberta (comunicar a decisão) é acompanhada de uma definição e tomada de decisão no decorrer do fluxo contínuo de ação. O que influencia a definição da situação são as interações com as outras pessoas (outros significantes) e com o self (julgamentos e sentimentos). Quando dizemos que nossas decisões derivam da interação significa que perspectivas são compartilhadas e objetos são continuamente definidos de modo diferente ou redefinidos. Nossos atos tornam-se importantes para aqueles ao nosso redor e, daí, seus atos tornam-se elementos na situação que se tem de definir.

Quando se diz que as decisões surgem da interação com o self, esta atitude significa que a pessoa está envolvida na ação encoberta, 
considerando objetos na situação, interpretando 0 ato dos outros e assumindo também o papel do outro. Os indivíduos não respondem ao mundo como ele é, mas a uma realidade ativamente definida por eles. Assim, caso se encontre uma situação como ameaçadora, devemos agir em conformidade com ela, mesmo que não pareça ameaçadora para outras pessoas. Portanto, nossas construções sociais da realidade são nossas definições das situações. Para Charon (2004):

O Interacionismo Simbólico descreve o ser humano como imprevisível e ativo no mundo. O ser humano é 'livre' de alguma forma, no que faz. Todos nós definimos o mundo em que atuamos. Parte desta definição é nossa própria vida: isso envolve escolhas conscientes, direções de acordo com as escolhas e avaliação de nossas ações e de outros re-direcionamentos.

Esta é outra ideia do Interacionismo apresentada por Charon (2004). O autor cita as seguintes atividades que envolvem a definição da situação: estabelecer metas na situação, aplicar a perspectiva do outro significante ou de um grupo de referência à situação, indicar ao self os objetos relevantes na situação (outras pessoas, coisas, ideias, palavras), assumir o papel do outro e definir o self na situação.

É importante destacar que, na perspectiva interacionista, o passado não causa os atos no presente, mas fornece os instrumentos que se usa para definir e guiar a ação no presente. Pessoas importantes, grupos de referência, perspectivas, conhecimentos e sentimentos do passado são usados como objetos sociais para se definir a situação presente.

O futuro também é fundamental para definir a situação. O que se faz no presente depende, em parte, das possíveis consequências futuras. Os atos têm consequências e tentamos imaginá-las quando agimos.

Outra ideia relevante do Interacionismo Simbólico apresentada por Charon (2004) é que:

O ser humano é entendido como agindo no presente, não apenas influenciado pelo que se sucedeu no passado, mas pelo que está acontecendo agora. O passado entra na ação, conforme o trazemos ao presente e o aplicamos à situação. Interação acontece agora e o que fazemos está ligado àquela interação. 


\title{
Interação Social
}

Todos os conceitos básicos para o Interacionismo Simbólico surgem da interação, que é construída na ação social; é simbólica quando significa que a ação de cada indivíduo tem significado para ambos, para quem criou e ao receptor da ação. Isto quer dizer que cada um está interagindo simbolicamente consigo, quando age em relação aos outros e como vê o outro.

Cabe ressaltar, ainda, a última ideia apresentada por Charon (2004):

\begin{abstract}
Os indivíduos interagem. Ao ter como foco a interação, o Interacionismo Simbólico cria uma imagem mais ativa do ser humano e rejeita a imagem de passivo, determinada pelo organismo. A interação implica pessoas agindo em relação a outras, percebendo, interpretando e atuando novamente. Os seres humanos e a sociedade são interdependentes. Interação implica pessoas agindo e levando em consideração umas em relação as outras, percebendo, interpretando e agindo novamente.
\end{abstract}

A interação social é construída a partir da ação social, isto é, quando se leva os outros em consideração ou quando tais ações são direcionadas pelo que as pessoas fazem. Neste processo, usamos símbolos, direcionamos o self, engajamo-nos em ações mentais, decidimos, mudamos de rumo, compartilhamos perspectivas, definimos a realidade e assumimos papéis. Quando a interação social é simbólica, estamos diante do significado de Interacionismo Simbólico: "[...] o estudo dos seres humanos que interagem simbolicamente entre si e com eles mesmos, e no processo dessa interação simbólica tomam decisões e dirigem seus fluxos de ação" (Blumer, 1969). Dizer que a interação é simbólica significa que os atos de uma pessoa têm importância para ela e para quem recebe a ação.

\section{Sociedade}

Para o Interacionismo Simbólico, a sociedade está sempre se desenvolvendo enquanto as pessoas estão interagindo. O Interacionismo vê a sociedade humana como formada de atores (pessoas representando) e a vida da sociedade em suas representações (ações) (Charon, 2004).

Ao clarificar os conceitos do Interacionismo apresentados por Mead e Blumer apud Charon (2004), os autores apresentam a ideia de sociedade como qualquer forma de vida grupal, definindo-a como indivíduos em 
interação social, assumindo o papel do outro, comunicando-se, interpretando um ao outro, ajustando seus atos aos do outro, dirigindo-se, controlando-se e partilhando perspectivas. Segundo o autor, é pela ocorrência do processo indicado que se diz que existe vida grupal, seja em relação a dois indivíduos, seja no tocante a uma organização mais completa.

A sociedade é caracterizada por interações simbólicas sociais. Os atores consideram e ajustam seus atos uns aos outros enquanto atuam; intencionalmente, eles se comunicam simbolicamente e interpretam uns aos outros. Dessa forma, a ação social está localizada no ator, que acomoda sua respectiva linha de ação ao outro pelo processo de interpretação. Sua decisão em relação à ação depende deste fato. A ação do grupo é coletiva de tais indivíduos.

Rosenblatt (2000), em um estudo com pais que vivenciaram a morte de um filho, conceitualizou o luto como ocorrendo em um contexto social, vivenciado pela família e outros grupos que compõem o contexto social.

Charon (2004) afirma que a sociedade é caracterizada por um tipo específico de interação de cooperação. A maioria das interações envolve a solução de problemas por ações cooperativas, mas algumas podem não ocorrer. A sociedade age cooperativamente para resolver problemas; considerando a perspectiva do Interacionismo, quando as ações não se caracterizam por um esforço cooperativo para lidar com as situações, não se constitui uma sociedade. Cooperação pode envolver ter os mesmos objetivos, mas não necessariamente; ela depende do fato de que interação é algo na qual os atores podem usar os recursos uns dos outros, a fim de agir efetivamente diante das situações, para lidar com os problemas maiores ou menores.

Para Charon (2004), em uma situação de resolução de problemas, cinco processos precisam ocorrer e caracterizam a cooperação, quais sejam: comunicação em andamento, mútua interpretação de papéis, definição do outro como objeto social, definição conjunta de objetos sociais e desenvolvimento de objetivos nas interações.

A sociedade possui uma cultura, uma perspectiva compartilhada que é refletida pela visão geral da realidade. É também possuidora de um corpo geral de regras, todas elas no intuito de facilitar uma interação social de 
cooperação. Na concepção de Charon (2004), o outro generalizado representa a sociedade para o indivíduo, cujas regras se tornam as suas próprias. É, portanto, a lei que deve ser seguida, o sistema, enfim, a "consciência" do indivíduo que ele utiliza para definir a situação.

Então, cultura pode ser entendida como uma perspectiva compartilhada, pela qual indivíduos em interação definem a realidade e um outro generalizado, mediante o qual indivíduos em interação adotam regras que controlam seus próprios atos. A cultura surge na interação simbólica; ela é uma qualidade central de qualquer sociedade, transforma-se em um objeto social importante para indivíduos que continuam cooperando para tal sociedade e guia seus pensamentos e o seu autocontrole (Charon, 2004).

Qualquer tipo de interação social simbólica que é cooperativa e desenvolve uma cultura é uma sociedade, desde pequenos grupos até grandes instituições. Cada indivíduo participa de várias sociedades e cada uma delas representa um papel na sua definição de realidade e autocontrole. Assim, este conceito tem fundamental importância neste trabalho para poder se compreender e definir família.

Como qualquer outra coisa na perspectiva do Interacionismo Simbólico, a sociedade humana é algo criado, definido, alterado e usado por atores que são ativos em seus papéis, possuidores de self e engajados em ação mental. Assim, somos socializados para aceitar a cultura, mas agimos nas direções de nossas escolhas e não como robôs (Charon, 2004).

$\mathrm{Na}$ perspectiva do Interacionismo Simbólico, o comportamento é influenciado pelo significado das ideias na mente. Assim, é possível encontrar uma conexão com a forma como a família faz um evento - pode ser ele a morte, doença, os cuidados paliativos - e como ela responde a tal evento.

É relevante para o presente trabalho saber o que direciona a constituição da realidade em um período de crise para se perceber um filho em cuidados paliativos. É substancial a exploração dos significados que a família atribui a esta nova condição. Quais as ações que ela desenvolve na manutenção, modificação e mesmo reconstrução da realidade no decorrer desta experiência? Quais significados aparecem diante da nova realidade 
familiar com uma criança/adolescente em cuidados paliativos e a iminência do processo de morte?

Frente à apresentação dos conceitos que constituem o Interacionismo Simbólico, pode-se assegurar que o comportamento familiar em cuidados paliativos é influenciado pelos significados que ela atribui às situações que vivencia na interação criança/adolescente doente, profissionais da área da saúde, os familiares e a própria trajetória da doença.

Ao se entender os conceitos da interação simbólica e a relevância que a perspectiva proporciona ao significado das experiências do indivíduo, acredita-se existir uma adequação à inquietação, dado que ela possibilitará entender os significados dados pela família em sua experiência diante do percurso do filho em cuidados paliativos.

\subsection{A Teoria Fundamentada nos Dados Como Referencial Metodológico}

Ao se definir o referencial conceitual, deve-se encontrar uma diretriz metodológica coerente com ele, a fim de indicar os rumos a serem seguidos no que diz respeito à coleta, organização e análise dos dados coletados. Em função da perspectiva teórica do Interacionismo Simbólico, optou-se pela Teoria Fundamentada nos Dados (TFD), conhecida como Grounded Theory, sugerida por Glaser e Strauss (1967), com o propósito de nortear o rumo para melhor entender 0 processo da experiência familiar de crianças/adolescentes em cuidados paliativos. Descobrir os significados que a família dá à sua experiência possibilita utilizar uma metodologia mediante a qual se compreende as ações do processo que serviram de experiência pela família (Bousso, 1999).

"O mundo é muito complexo [...]" comprovam Strauss e Corbin (2008, p. 8); para eles não há explicações para o que acontece. Os fatores da convivência social interagem, somam-se e resultam em eventos. Qualquer metodologia de pesquisa que tenha por fim abranger as experiências ou explicar as situações não pode ser simples. Para os autores, a metodologia qualitativa proporciona ao pesquisador que adentre na experiência dos 
participantes para testemunhar como os significados são formados. Segundo eles, a análise na pesquisa qualitativa dá significado aos dados.

A pesquisa na metodologia qualitativa propicia ao pesquisador observar atentamente os dados a partir de uma perspectiva específica; em outras palavras, Ihe dá a oportunidade de optar como os dados serão coletados e estudados, no sentido de atender a necessidade da investigação. Não raramente, a pergunta da pesquisa é aberta e sua tendência é se tornar focalizada no decorrer do desenvolvimento e a partir da convivência com os dados que envolvem o problema.

Uma das considerações essenciais da metodologia qualitativa de Strauss e Corbin (2008) é a prática de sensibilidade dos pesquisadores. Apesar de eles deverem iniciar as pesquisas qualitativas sem ideias preconcebidas, para os autores há certa dificuldade dessa garantia. Além disso, eles questionam até que ponto o conhecimento prévio pode redundar em prejuízo ou se a experiência prévia não facilitaria o desenvolvimento da pesquisa. Para este tema, asseveram que a resposta é o uso da ponderação entre o que já se conhece ou qual a experiência prévia e os novos achados do estudo.

No desenrolar da pesquisa, a ideia de processo foi garantida, uma vez que as ações e interações que envolvem a experiência familiar com uma criança/adolescente em cuidados paliativos resultam da transformação das respostas às consequências dos eventos que os seres humanos enfrentam. $\mathrm{Na}$ opinião de Blumer (1969), os conceitos fazem parte da linguagem usada pelos participantes para questionar a compreensão da situação ou da experiência.

O pesquisador penetra no mundo e na experiência com os participantes e percebe o que eles estão vivendo. Nessa situação, ele adquire novos conhecimentos com as propriedades do fenômeno em estudo. (Strauss e Corbin, 2008).

A metodologia da Teoria Fundamentada nos Dados foi desenvolvida por Glaser e Strauss em 1967 e se propõe a expandir uma teoria sobre o fenômeno estudado a partir dos dados coletados.

A epistemologia do método, segundo Strauss e Corbin (2008), originase de duas fases, envolvendo a tradição do Interacionismo Simbólico de 
Chicago (Chicago School of Sociology and Symbolic Interactionism) e a filosofia do Pragmatismo herdada de John Dewey e George Mead.

Para Burden e Roodt (2007), há distintas escolas de estudo e aplicação da Teoria Fundamenta nos Dados. Para os autores, a metodologia desenvolve-se em duas perspectivas tidas como as mais tradicionais. De um lado está a perspectiva desenvolvida por Glaser (1978), que reforça as naturezas interpretativa, contextual e emergente da teoria; de outro está a de Strauss, que ressalta a técnica complexa e sistemática de codificar. Strauss e Corbin, a partir de 1990, indicam o processo de codificação como aberta, axial e seletiva, aplicado de modo comparativo; eles realizam o processo em três fases, enquanto que Glaser (1978) somente a utiliza em duas, valorizando a codificação aberta e seletiva dos dados.

A partir dos anos 1990, novas formas de desenvolver a metodologia foram apresentadas, chamadas características construtivistas da Teoria Fundamenta nos Dados. Neste foco, a versão de Bryant (2003), ReGrounding grounded theory, discute como construir a teoria a partir dos dados. Em 2010, Bryant e Charmaz publicaram o livro Handbook of grounded theory.

Gibbs (2010) sustenta, atualmente, que há, pelo menos, três versões da TFD:

1. a de Glaser, da década de 1970, na qual a teoria deve emergir dos dados, sem que estes sejam formados a partir da "força" do investigador;

2. a prescritiva e desenvolvida a partir das categorias de Strauss e Corbin na década de 1980;

3. a construtivista de Charmaz na década de 1990, com as categorias e a teoria sendo construídas pelo pesquisador.

A TFD, na visão de Bryant (2009), significa uma aproximação sistemática, indutiva e comparativa de conduzir questionamentos com a finalidade de construir uma teoria. É preciso que o pesquisador interaja de forma intensa e constante com os dados, concomitantemente ao realizar a análise.

"Construir uma teoria própria a partir de dados coletados exige que o pesquisador inicie o processo sem, ou talvez com o menor número de hipóteses a descobrir." (Glaser e Strauss, 1967, p. 2). 
Esse primeiro passo conduz o investigador a permanecer de forma mais sensível diante dos dados, sem que realize filtração ou os com suas próprias hipóteses (Glaser, 1978, pp. 2-3). Assim, “[...] o pesquisador entra na área do estudo e permite que a teoria seja criada a partir dos dados que ele coleta." (Strauss e Corbin, 1998, p. 12).

O estudo usou a versão da TFD de Strauss e Corbin (2008), tendo foco a dimensão interacional das respostas dos familiares de crianças/adolescentes em cuidados paliativos frente à experiência com suas crianças/adolescentes nestas condições.

Para Strauss e Corbin (2008), a Teoria Fundamentada nos Dados significa que ela foi derivada de dados cuidadosamente analisados mediante pesquisa, onde sua coleta, análise e a própria teoria estão relacionadas e acontecem ao mesmo tempo. Por basear-se em dados, pode proporcionar melhor discernimento, compreensão e fornecer uma diretriz de destaque para a ação.

Na concepção de Morse e Richards (2002), por meio da exploração detalhada e da sensibilidade teórica, pode-se construir uma Teoria Fundamentada nos Dados, a qual, via de regra, tem uma história única. Ela apresenta um conceito central e uma teoria que dão sentido aos dados, explorando as relações entre os conceitos que compõem o processo.

Neste particular, uma teoria caracteriza um conjunto de categorias bem desenvolvidas e inter-relacionadas para compor uma estrutura teórica que explique os fenômenos sociais, psicológicos, educacionais e os relacionados às experiências de saúde-doença relevantes (Strauss e Corbin, 2008).

\subsubsection{Implicações metodológicas da teoria fundamentada nos dados}

Em virtude da finalidade de capturar a complexidade da experiência durante a pesquisa, as experiências foram vinculadas às suas estruturas social, política, cultural, racial, de gênero e tecnológica.

No desenrolar da pesquisa, o processo foi mantido, tendo em vista que as ações e interações que envolvem a experiência familiar da 
criança/adolescente em cuidados paliativos redundam da transformação de suas respostas às contingências e consequências dos fatos que os seres humanos enfrentam. Os conceitos, conforme Blumer (1969), fazem parte da linguagem comum usada pelos participantes para discutir a compreensão da situação ou da experiência.

Ao pesquisador é permitido adentrar no mundo e na experiência com os participantes e revelar o que estão vivendo. Nessa convivência no mundo deles, o pesquisador desenvolve outros conhecimentos com as características do fenômeno em estudo (Strauss e Corbin, 2008).

\subsection{Desenho da Pesquisa}

\subsubsection{Contexto da coleta de dados}

O contexto dos cuidados paliativos pediátricos é peculiar e está composto por diversos aspectos, como:

- Variedade de doenças, muitas das quais raras e de caráter familiar.

- Diferentes prognósticos, por vezes incertos.

- Local de promoção dos cuidados, avaliação e manejo dos sintomas.

- Aspectos éticos.

- Maior envolvimento e sofrimento dos cuidadores e contínuos desenvolvimentos físico, emocional e cognitivo da criança (Lenton et al., 2006).

Dessa forma, esses cuidados podem ser necessários desde a infância e permanecem por muitos anos em algumas crianças e, em outras, apenas quando mais velhas e por um curto período. Crianças com doenças não oncológicas, que limitam a vida, podem sobreviver por muitos anos e mesmo décadas, com necessidades médicas complexas, prévias a uma morte prematura. Além disso, durante o curso da doença, podem apresentar diversos episódios em que a morte parece iminente e se recuperarem até 0 próximo episódio (Hyson, 2006). 
Conforme o diagnóstico, algumas delas permanecem na fase de transição entre um tratamento curativo para um exclusivamente paliativo por anos ou décadas, como nas prematuras, com fibrose cística e HIV/aids avançada (Hutton et al., 2006). Em crianças com câncer, nem sempre é possível determinar quando a doença responderá à terapia proposta, assim como a trajetória do processo de morte (Hyson, 2006).

Nesse panorama é que esta pesquisa foi realizada. Os dados foram coletados no Ambulatório da Unidade de Dor e Cuidados Paliativos de um hospital público da cidade de São Paulo, de nível terciário, com características de ensino e pesquisa.

O ambulatório da Unidade de Dor e Cuidados Paliativos está formado há 10 anos e presta atendimento a crianças e adolescentes portadoras de patologias variadas, como: oncologia, reumatologia, infectologia, hematologia, hepatologia, neurologia e dermatologia, entre outras. Neste ambulatório, são acompanhadas crianças e adolescentes portadores de patologias clínicas complexas, que recebem terapias curativas, de controle da patologia e também as crianças e adolescentes que recebem terapia paliativa exclusiva.

O serviço em questão é multidisciplinar, composto por médicos, enfermeira, fisioterapeuta, dentista, terapeuta ocupacional, psicóloga, assistente social, nutricionista e fonoaudióloga. Até o momento, a instituição não oferece assistência domiciliar às crianças/adolescentes em cuidados paliativos e às suas famílias.

O atendimento ambulatorial ocorre em três períodos da semana, sendo que no Serviço de Onco-Hematologia é realizado às quartas e quintas-feiras, no período da manhã; no ambulatório de doenças não oncológicas, ele é realizado uma vez na semana, às quintas-feiras, no período da tarde. O atendimento para pacientes com afecções oncohematológicas e não oncológicas é feito separadamente porque, fisicamente, o prédio destinado à oncologia e hematologia encontra-se separado. As estruturas hierárquica e administrativa para os dois ambulatórios são as mesmas. 
A Instituição não apresenta uma unidade de internação específica para os pacientes em cuidados paliativos. Quando a internação é necessária, crianças e/ou adolescentes são hospitalizados nos leitos disponíveis nas enfermarias e atendidos pelas equipes de cuidados paliativos e pela especialidade à qual elas pertencem.

A inclusão de um paciente para a equipe de Dor e Cuidados Paliativos é efetuada mediante encaminhamento dos pacientes e familiares pelas diversas especialidades médicas que atendem a criança/adolescente por sua patologia de base, por meio de contato telefônico e/ou pedido de consulta, e depende da aceitação da família em realizar o seguimento. $O$ seguimento ambulatorial da criança/adolescente ocorre com datas de retorno pré-agendadas ou conforme a solicitação da família.

\subsubsection{Participantes do estudo}

Ao se escolher uma metodologia qualitativa para o presente estudo, usou-se a concepção da amostra teórica. De acordo com Glaser e Strauss (1967), a amostra teórica significa o processo de coleta e análise simultânea dos dados. Desse modo, ao avaliar os resultados da análise dos dados, o pesquisador tem condições de definir quais dados deverão ser incluídos e onde encontrá-los. Ao se usar esse processo, o resultado da coleta e análise dos dados dará origem a uma teoria sobre o evento estudado.

Corbin e Strauss (2008, p. 143) explicam o termo "amostra teórica" como

[...] definição do pesquisador em que lugares, com quais pessoas e em que eventos poderão maximizar as oportunidades de desenvolver conceitos em termos de suas propriedades e dimensões, incluindo as possíveis variações.

Dessa forma, os participantes desta pesquisa foram famílias de crianças/adolescentes em cuidados paliativos que atendiam aos seguintes critérios de inclusão:

- A criança/adolescente estar sendo acompanhada ou já ter sido acompanhada pelo grupo de Dor e Cuidados Paliativos (no caso 
das entrevistas feitas com as famílias cujos filhos já haviam falecido).

- A criança /adolescente fosse portador de uma "condição limitante de vida" ou portador de uma "condição que ameaça a vida", sem possibilidade terapêutica de cura e que esta informação estivesse documentada no seu prontuário clínico.

- A família já tivesse sido informada pela equipe de saúde da não possibilidade terapêutica de cura da doença de suas crianças/adolescentes, fato que deveria também estar documentado em prontuário clínico.

O acesso inicial às famílias deu-se por meio do acompanhamento dos atendimentos ambulatoriais e das visitas às unidades de internação realizadas pela equipe de Dor e Cuidados Paliativos. A abordagem às famílias foi feita pessoalmente pela pesquisadora na unidade ambulatorial, enquanto as famílias aguardavam o atendimento com o grupo de cuidados paliativos ou pós-consulta ambulatorial. Nos casos de internação, a abordagem primeiramente se fez pela médica da Unidade de Dor e Cuidados Paliativos, com o objetivo de pedir autorização à mãe para que a pesquisadora a procurasse e lhe explicasse sobre a pesquisa. A partir desse consentimento, a pesquisadora apresentava-se à unidade de internação para realizar a abordagem.

Também foram abordadas famílias em que a criança/adolescente havia sido acompanhada pela Unidade de Dor e Cuidados Paliativos e que já haviam falecido. Apesar de não haver um protocolo estabelecido pelo grupo para o atendimento a estas famílias na situação do pós-morte, algumas famílias ainda mantinham contato com o grupo de cuidados paliativos, principalmente mediante conversas telefônicas e quando solicitado são atendidas pela equipe em datas pré-agendadas. Desse modo, o contado inicial com estas famílias foi feito por uma das médicas da unidade, que, por telefone, pedia autorização da família para disponibilizar o contato para que a pesquisadora pudesse, então, telefonar e falar sobre a pesquisa.

O contato para o convite em participar da pesquisa foi feito para a mãe da criança/adolescente em todos os casos, porque era a pessoa que, 
na maioria das vezes, estava presente no ambulatório ou na hospitalização com a criança/adolescente. Nos casos das crianças já falecidas, era quem ainda mantinha contato com a equipe de cuidados paliativos. Assim sendo, eram explicados os objetivos e procedimentos da pesquisa e quando estas famílias demonstravam interesse em participar do estudo ou pensar sobre a possibilidade de participação, era solicitado às mães que também estendessem o convite de participação na pesquisa a outros membros familiares. Nessa ocasião, foi oferecido um período de duas a três semanas para que a família decidisse sobre a participação e quem dela participaria. Algumas mães comprometeram-se a dar a resposta na próxima consulta ambulatorial do filho; em outros casos, combinou-se uma data para um contato telefônico para que dissessem sobre a possibilidade ou não da participação.

No total, foram abordadas 28 famílias de crianças/adolescentes em cuidados paliativos; destas, quatro delas recusaram-se a participar do estudo no ato do convite, alegando não sentir vontade de falar sobre a experiência de doença do filho. Nestes quatro casos, a mãe foi a pessoa abordada. Dez famílias aceitaram participar no momento do convite e 14 optaram aguardar por um tempo para decidirem se aceitariam ou não participar do estudo; destas, cinco consentiram participar. Quatro delas recusaram-se após decisão compartilhada, segundo a mãe da criança, com o marido. Cinco famílias vivenciaram o processo de morte da criança no período entre o contato da pesquisadora e o tempo para decidir sobre a participação e resolveram não participar.

Verificado o interesse da família em participar do estudo, procedeu-se o agendamento de data, horário e local mais convenientes para ela.

Dessa maneira, participaram do estudo 15 famílias de crianças/adolescentes em cuidados paliativos, sendo 10 portadores de afecções oncológicas (três osteossarcomas com metástases, um tumor de células germinativas de sistema nervoso central, um tumor de sistema nervoso central; três neuroblastomas;uma leucemia linfoide aguda e um linfoma de Burkitt) e cinco com afecções não oncológicas (um neuropatia degenerativa, um mielopatia associada ao HTLV, um mielomeningocele e 
paralisia cerebral, um dermatopolimiosite e um xeroderma pigmentoso). 0 total foram 20 membros familiares entrevistados, assim distribuídos: 15 mães, três pais, um avô, uma tia paterna.

O número de famílias foi se configurando em razão da análise de seus depoimentos. À medida que a análise dos dados prosseguia, buscavam-se novos dados, para que as categorias fossem melhor desenvolvidas e densificadas. A coleta destes dados foi realizada até acontecer a saturação teórica, quando se verificaram repetição e ausência de dados novos e crescente compreensão dos conceitos identificados (Strauss e Corbin, 2008).

Em relação às crianças e adolescentes em cuidados paliativos, nove eram do sexo feminino e seis do masculino; tinham pelo menos um irmão, com exceção de apenas uma das crianças, que era filha única. $\mathrm{O}$ tempo de inclusão e acompanhamento destas crianças/adolescentes na Unidade de Dor e Cuidados Paliativos variou de um mês a três anos.

Os dados foram coletados mediante entrevistas feitas na casa das famílias (três), no próprio hospital (sete) ou na Escola de Enfermagem da USP (cinco), sempre respeitando a preferência do membro familiar a ser entrevistado. Nas entrevistas feitas fora do ambiente domiciliar, foram previamente agendadas pela pesquisadora salas privativas, para que se pudesse assegurar a privacidade dos participantes.

Em relação à forma de participação dos membros familiares, foram feitas 13 entrevistas individuais, uma com o grupo familiar com três membros presentes e duas conduzidas com o casal. Em 11 famílias, as entrevistas foram realizadas apenas com a mãe da criança/adolescente.

O primeiro grupo amostral foi constituído de quatro famílias, sendo duas com crianças que apresentavam afecções oncológicas e duas famílias cujos filhos apresentavam afeç̧ões não oncológicas, que estavam em cuidados paliativos ambulatoriais, apesar da progressão da doença. $O$ objetivo desta aproximação foi apreender como vivenciavam a experiência para descobrir as categorias iniciais que direcionariam a coleta de dados e a formação de outros grupos amostrais. Após a análise dos dados iniciais, surgiram algumas questões: 
- Será que a experiência de ter o filho em cuidados paliativos internado influenciava na percepção dos familiares sobre o significado e entendimento que dava aos cuidados paliativos?

- Havia diferenças no manejo da situação do filho em cuidados paliativos quando este estava em cuidados paliativos no domicílio ou no hospital?

- Por que algumas famílias se davam conta de que o filho estava em cuidados paliativos e outras não?

A partir disso, foi composto o segundo grupo amostral com quatro famílias que se encontravam com o filho em cuidados paliativos em situação de hospitalização, sendo três com diagnósticos oncológicos e um com afecção não oncológica. Duas delas, no caso com o filho portador de câncer, encontravam-se em situação de final de vida. Aqui, buscava-se ampliar o sentido da experiência e outras indagações surgiram a partir destas análises:

- Em que momento da experiência a família se dava conta que o filho estava em cuidados paliativos?

- De que forma ocorria esta percepção?

- Quando a família se deu conta que a criança/adolescente estava morrendo?

Assim, um terceiro grupo amostral foi formado por quatro famílias, cujos filhos já haviam falecido. O grupo foi constituído por três famílias de crianças com doença oncológica e uma em que a criança era portadora de afecção não oncológica.

O último grupo amostral contou com três famílias e foi formado para validar o modelo teórico proposto; duas delas portadoras de afecções oncológicas e uma com afecção não oncológica, sendo uma em situação de acompanhamento ambulatorial, uma em situação de hospitalização e outra cujo filho já havia falecido.

De acordo com Strauss e Corbin (2008), com o desenvolvimento de mais de um grupo amostral, é possível maximizar as diferenças nas propriedades, permitindo a construção de variações na teoria e aumentando seu poder explanatório.

O Quadro 1 representa a caracterização das famílias participantes. 


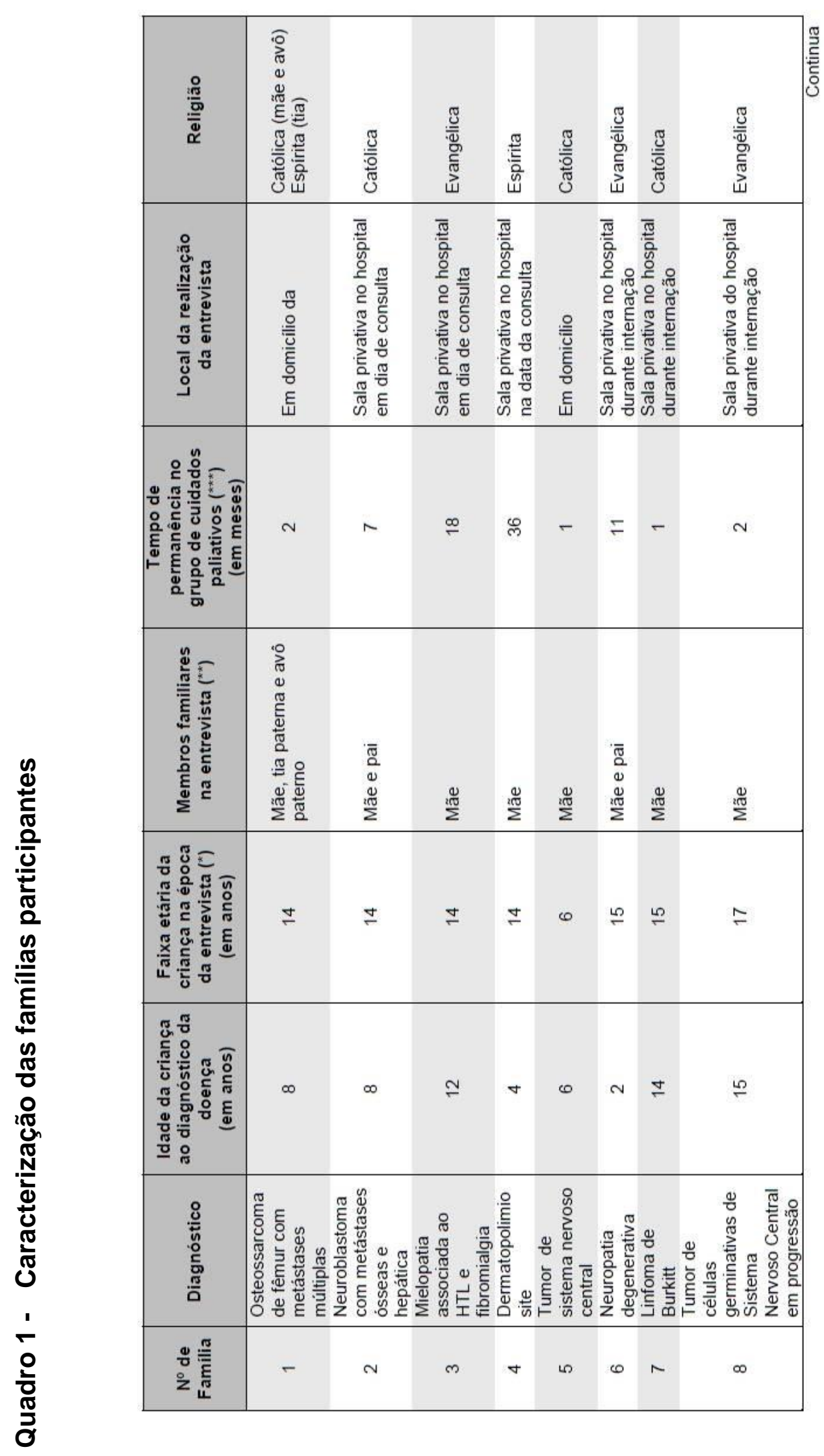




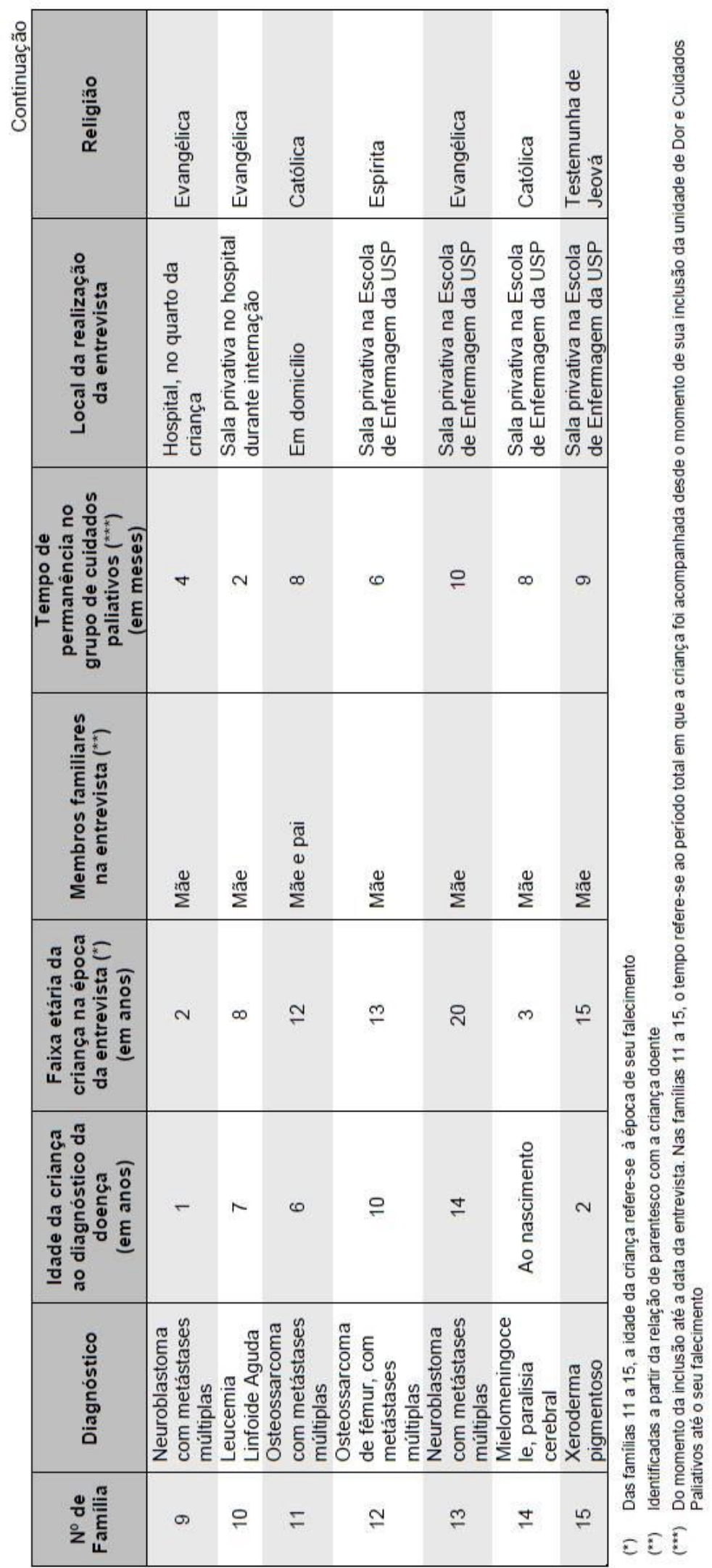


A seguir, será apresentada uma breve descrição das famílias, os membros participantes da pesquisa são identificados por letras maiúsculas escolhidas aleatoriamente seguidas de um número - que representa o número dado à família, o qual também foi aleatoriamente escolhido - para preservação de suas identidades. As crianças e adolescentes em cuidados paliativos, bem como seus irmãos, receberam nomes fictícios, a fim de mantermos e respeitarmos o seu anonimato.

\section{Família 1}

A família, procedente de Osasco e residente em uma comunidade de baixa renda, é composta pelo pai, T1, 37 anos, atualmente desempregado, desenvolvendo atividades informais, como pintor, e realizando carretos, pela mãe, U1, 34 anos, costureira em uma fábrica de roupas, trabalhando das 16 às 22 horas, de segunda a sexta-feira e hoje é a provedora financeira da família. Casados há 16 anos, eles possuem dois filhos, Paulo, 14 anos, portador de osteossarcoma e metástases múltiplas, em cuidados paliativos exclusivos, e uma filha, Camila, com oito anos, estudante da terceira série.

Em abril de 2004, Paulo foi diagnosticado com osteossarcoma de fêmur direito aos oito anos. Realizou cirurgia para ressecção do tumor e foi necessária amputação da perna direita, cujo procedimento aconteceu também em 2004. No decorrer do tratamento, apresentou metástases pulmonar, renal e no pâncreas, sendo necessárias outras cirurgias para ressecção dos tumores. Apesar do tratamento, evoluiu com metástases múltiplas e há dois meses da data da entrevista, foi encaminhado pela oncologia à Unidade de Dor e Cuidados Paliativos. Ele cursava a oitava série do Ensino Fundamental, mas, segundo a mãe, há quatro meses resolveu não frequentar mais a escola por opção própria.

Da entrevista participaram, além da mãe, o avô paterno, V1, 65 anos, aposentado, e a tia paterna, $\mathrm{X} 1,40$ anos, que trabalha como oficial administrativa em uma fábrica e reside junto com a família, a fim de auxiliar nos cuidados com Paulo desde o momento do diagnóstico inicial da doença. Ela foi a responsável por acompanhá-lo a todas as consultas ambulatoriais. Mas, atualmente, por estar desempregado, o pai é o seu cuidador principal no domicílio. 
Paulo faleceu dois meses após a entrevista e a informação sobre o óbito foi fornecida pela tia, por contato telefônico, uma semana após. Segundo ela, o sobrinho permaneceu internado três dias antes de sua morte e faleceu "em paz". Refere, ainda, à dificuldade da família em conseguir colocar a vida em ordem a partir desse momento e à ausência de Paulo como um "buraco aberto na família", que não sabe quando conseguirão fechá-lo, se é que isto será possível um dia.

\section{Família 2}

Esta família, residente em Mogi das Cruzes, é constituída pelo pai, Q2, 44 anos, mecânico e proprietário de sua oficina, pela mãe, R2, 44 anos, dona de casa, pela filha, Ana, 14 anos, estudante e pelo filho, Ricardo, 6 anos, que também frequenta a escola. As consultas são feitas em São Paulo. Quando vêm para cá, hospedam-se em um apartamento de uma amiga, que se localiza próximo ao hospital, o que facilita, segundo a mãe, a rotina de seguimento do tratamento. Contam com carro próprio para a locomoção.

Ana foi diagnosticada em julho de 2004 com neuroblastoma. Em 2007, apresentou recidiva da doença, sendo iniciado novo tratamento e feito transplante de medula. Em fevereiro de 2010, houve nova recidiva da mesma doença, com metástases ósseas; a partir de então, foi encaminhada para a Unidade de Dor e Cuidados Paliativos em julho de 2010.

Durante a entrevista, ela realizava seguimento ambulatorial com equipe de cuidados paliativos há sete meses; encontrava-se também em seguimento com oncologia, porém com terapêutica exclusivamente paliativa, com metástases ósseas e hepática. Ana freqüentava a oitava série do Ensino Fundamental e, de acordo com a mãe, estava ansiosa pelo regresso à escola, pois, no ano anterior, a filha tivera dificuldade em frequentar a escola "por conta da doença" e das fortes dores que sentia. A sua cuidadora principal no domicílio é a mãe.

A entrevista foi realizada com os pais de Ana, no próprio hospital, em um de seus retornos ambulatoriais com o oncologista e a equipe de paliativos.

Em dezembro de 2011, uma das médicas do grupo de cuidados paliativos informou que a adolescente estava internada na enfermaria e muito 
debilitada. Ao chegar lá, deparou-se com Ana agitada, queixando-se de fortes dores de cabeça e sua mãe, ao lado da cama, muito aflita. Começou a falar sobre o estado de saúde da filha e disse não se conformar em vê-la daquela forma. As equipes médicas e de enfermagem a atendem no momento. Presenciou-se a conversa de Ana com sua mãe, onde the pede que a deixe partir. R2, por sua vez, Ihe respondeu que jamais permitiria isso.

Ana melhorou e conseguiu dormir. Sua mãe pede para conversarmos e descreve, com pesar e minuciosamente, seus receios e preocupações sobre a possibilidade de perder a filha; reafirma que mesmo sabendo que a morte possa acontecer e parecer estar perto, só a Deus caberá esta decisão e que seu papel restringia-se em continuar lutando pela vida da filha.

Ana faleceu na manhã seguinte em companhia da mãe, que solicita à médica do grupo de paliativos que avisasse a entrevistadora sobre o ocorrido e que esta Ihe telefonasse. Falou-se com R2 por telefone dois dias após o ocorrido. Ela assegura estar sendo muito difícil acreditar que a filha partiu, mas o que a tranquilizava e amenizava um pouco a sua dor era saber que agora Ana estaria descansando e livre das dores, pois sabia que esse tinha sido o seu último pedido.

\section{Família 3}

Esta família reside no Grajaú, distrito de São Paulo, e é composta pelo pai, Y3, 42 anos, mestre de obras e provedor financeiro da família, pela mãe, W3, 39 anos, merendeira, e três filhos: Márcio, 20 anos, Carla, 17 e Elaine, 15 , todos estudantes.

Elaine é portadora de uma mielopatia associada ao protovírus Tlinfotrópico humano (HTLV), diagnosticada em 2007, quando tinha 12 anos. No momento da realização da entrevista, estava com 15 anos e sendo acompanhada pela Unidade de Paliativos há 18 meses. Cursa a oitava série do Ensino Fundamental, mas vem encontrando dificuldades em seguir os estudos por estar perdendo muitas aulas em virtude da progressão da doença. A mãe refere-se a ela como sendo uma filha estudiosa e que não falta às aulas; relata que se ausentar da escola a deixa triste. Acredita que Elaine sinta-se diferente de suas amigas de escola pela sua situação atual 
de doença. Movimenta-se com certa dificuldade e, em algumas situações, necessita ser amparada por terceiros, o que a desanima e a faz desistir de sair em companhia de suas amigas.

A entrevista - que precisou ser remarcada três vezes, pelo fato de Elaine encontrar-se com crise álgica e indisposta - foi realizada com a sua mãe no próprio hospital, em um dia de retorno ambulatorial com o grupo de paliativos. W3 trabalhava como merendeira e se dividia entre 0 trabalho e 0 cuidado da filha, uma vez que para poder realizar o acompanhamento ambulatorial tinha de faltar ao serviço no mínimo uma vez por semana. Com a progressão da doença e, consequentemente, a piora do quadro clínico, a mãe demitiu-se do serviço para poder dedicar-se exclusivamente aos cuidados da filha. Ela lamenta não poder contar com o apoio do marido no momento de tomada de decisões necessárias para o tratamento da filha, dado que o trabalho de Y3 exige que ele retorne para casa apenas aos finais de semana.

A mãe relata que vivem em um bairro periférico, sem calçamento pavimentado, o acesso é de terra, com muitos buracos e obstáculos, o que dificulta a locomoção independente de Elaine. W3 também faz referência à distância entre a sua residência e o hospital como um obstáculo enfrentado para o seguimento ambulatorial do tratamento e vida cotidiana da filha.

Até o fechamento desta pesquisa, Elaine mantinha-se em seguimento ambulatorial com o grupo de paliativos.

\section{Família 4}

A família reside no bairro de Itaquera, zona leste de São Paulo. O pai, S4, 41 anos, é oficial administrativo e a mãe, R4, 38 anos, é professora da rede municipal de ensino. Eles são separados e mantêm contato esporádico, mas, algumas vezes, S4 acompanha a ex-esposa às consultas médicas da filha.

Viviane, 14 anos, reside com a mãe e é portadora de dermatopolimiosite, desde os quatro anos, seguindo acompanhamento reumatológico desde então. Ela frequenta a sétima série do Ensino Fundamental. Consoante sua mãe, ela era boa aluna e se chateia quando se encontra indisposta ou impossibilitada de ir à escola devido à sua doença. R4 assegura que a filha não se vê como diferente dos outros e que tenta 
sempre adaptar a sua condição à rotina e ao que deseja fazer. E acrescenta que a encoraja nessas atitudes.

No momento da entrevista, Viviane estava sendo acompanhada pela Unidade de Paliativos há três anos. Somente a mãe, cuidadora principal, participou da entrevista. Sua jornada de trabalho é nos períodos da manhã e noite, necessitando, então, faltar quando precisa trazer a filha aos retornos médicos; além do grupo de paliativos, Viviane é acompanhada pela reumatologia e nefrologia. $\mathrm{R} 4$ refere ter tido de se adaptar a esta rotina porque, desde muito pequena, a filha apresenta problemas de saúde e requer acompanhamento médico regular, sendo uma de suas maiores dificuldades conciliar seu trabalho com os cuidados com a filha.

Viviane manteve o seguimento ambulatorial com a Unidade de Paliativos até a conclusão deste trabalho.

\section{Família 5}

A família é composta pelo pai, $X 5,31$ anos, vigilante noturno e provedor financeiro da família, pela mãe, Z5, 31 anos, dona de casa no momento (deixou o serviço de caixa de supermercado para dedicar-se ao cuidado da filha), e os filhos, Pedro, 14 anos, Diogo, 12, Marília, seis e Mateus, dois. No domicílio, estavam presentes os quatro filhos do casal, a mãe e a avó materna, que não quis participar da entrevista,permanecendo durante todo o tempo no quarto com os netos e a porta fechada.

A entrevista foi realizada no domicílio da família, no Grajaú, distrito da cidade de São Paulo. X5 encontrava-se trabalhando, o que justifica sua não participação. Dessa forma, a entrevista foi realizada apenas com a mãe.

Marília foi diagnosticada com um tumor de sistema nervoso central aos seis anos, quando foi realizada uma cirurgia de ressecção parcial do tumor e iniciado tratamento de radioterapia e quimioterapia. Alimenta-se por sonda de gastrostomia, não se comunica verbalmente; necessita da mãe para realizar os cuidados integrais. Z5 refere que o mais difícil é aceitar a condição de dependente física de sua filha e o fato de ela não mais se comunicar verbalmente. 
Apesar da terapia proposta, a doença segue em progressão. $\mathrm{Na}$ época da entrevista, estava em acompanhamento pelo grupo de cuidados paliativos há um mês,alternando períodos de hospitalização com permanência no domicílio, o que variava de acordo com o seu estado clínico.

\section{Família 6}

Residente em Osasco, a família é composta pelo pai, T6, 45 anos, a mãe, U6, 43, duas filhas, Carol e Raquel, 19 e 17 anos, respectivamente, e o filho Isaú, 15anos. Um sobrinho do casal reside junto com a família e é referido como um elemento importante no cuidado da criança doente.

A entrevista foi realizada com os pais, separadamente, durante a internação de Isaú, uma vez que o casal se revezava no cuidado com o filho no hospital, adequando os horários à sua rotina de trabalho. O pai tem emprego fixo, é segurança durante o período noturno, e a mãe trabalhava em casa de família. Com a progressão da doença do filho, ela preferiu demitir-se do emprego fixo e realizar trabalhos esporádicos, como faxineira, o que lhe possibilita uma agenda mais flexível para poder cuidar do filho. $O$ casal ressalta a união da família e o apoio de todos os integrantes da casa voltado ao cuidado de Isaú. A mãe é a cuidadora principal no domicílio.

Isaú é portador de uma neuropatia degenerativa diagnosticada quando ele tinha um ano. Segundo os pais, o acompanhamento médico sempre foi realizado com neurologistas em um convênio médico da família. Há dois anos foram encaminhados para o seguimento no Hospital das Clínicas e, na data da entrevista, estavam sendo acompanhados pelo grupo de paliativos há 21 meses.

Isaú segue em cuidados paliativos em regime ambulatorial até a conclusão desta coleta de dados, é dependente de oxigênio domiciliar, é portador de traqueostomia e gastrostomia, sendo, pois, dependente de cuidados integrais. Vale registrar que Isaú não se comunica verbalmente. 


\section{Família 7}

A família mora em Cuiabá e é constituída pelo pai, X7, 46 anos, autônomo, pela mãe, K7, 50, engenheira ambiental, licenciada desde a descoberta da doença do filho, e pelos três filhos: Piero, 18 anos, Sandro, 16, e Rafael, 15. Os pais são separados, mas, apesar disso, segundo a mãe, o ex-marido sempre foi e continua presente na vida dos filhos.

Rafael foi diagnosticado com Linfoma de Burkitt em junho de 2010. Ele cursou até a oitava série do Ensino Fundamental, tendo de interromper os estudos em virtude do tratamento. No momento da entrevista, realizada com K7 no hospital em local privativo, ele encontrava-se na enfermaria de oncologia sob terapia paliativa exclusiva.

Rafael e sua mãe estão há três meses em São Paulo. Ela resolveu, então, buscar uma nova opinião sobre o prognóstico do filho, dado que a equipe de Cuiabá dissera não haver mais terapia a ser proposta para a cura da doença. Com novos exames em São Paulo, o panorama foi o mesmo. Ele está em acompanhamento pela Unidade de Paliativos há dois meses.

Rafael foi transferido para um hospital de Cuiabá cinco dias após a entrevista, conforme solicitação sua e da mãe. A equipe relatou que ele pedia insistentemente para voltar para casa e rever familiares e amigos. Faleceu aproximadamente dois meses após sua transferência, de acordo com a equipe da oncologia.

\section{Família 8}

A família mora em uma favela na periferia de São Paulo. O pai, S8, 41 anos, e a mãe, T8, 38 anos, são separados. Eles têm um filho, Vinícius, 17 anos, e a mãe, uma filha, Silvana, sete anos, do segundo casamento.

Vinícius é portador de um tumor de células germinativas do sistema nervoso central, descoberto e operado em agosto de 2008. Em janeiro de 2010, apresentou recidiva da doença, sendo submetido a nova cirurgia e tratamento quimioterápico. Houve uma evolução progressiva da massa tumoral craniana, apesar das terapias realizadas. Ele apresenta hemiplegia esquerda e não se comunica verbalmente, sequelas estas decorrentes da primeira cirurgia realizada para ressecção do tumor e passou a se alimentar por gastrostomia. 
Em 2010, tornou-se dependente de oxigênio domiciliar. A família reside em local de difícil acesso e em condições muito precárias, o que dificultando, sobremaneira, o acesso sobretudo de carros, ambulâncias e, consequentemente, o deslocamento do paciente para tratamento hospitalar.

De acordo com a mãe, há 15 anos seu ex-marido não visita nem fala com o filho. Após a descoberta da doença, ela o avisou sobre o ocorrido com Vinícius, mas, mesmo assim, não o procurou.

T8 trabalhava em casa de família, mas foi obrigada a se demitir desde o início do processo de doença do filho para dedicar-lhe cuidado integral. Casou-se novamente e vive com o atual companheiro, que tem 39 anos e sem vínculo empregatício, realizando apenas trabalhos informais, como ajudante de pedreiro. Silvana, praticamente desde o diagnóstico, passou a morar com uma tia materna.

No momento da entrevista, o paciente estava internado em cuidados paliativos exclusivos, fora de possibilidades terapêuticas de cura, encontrando-se em situação de final de vida. Recebia acompanhamento pelo grupo de cuidados paliativos há um mês. Sua mãe demonstrou muita receptividade em participar do estudo.

A entrevista foi feita em uma sala de reuniões do hospital. Durante este período, sua ex-patroa, que visitava Vinícius, permaneceu com ele no quarto. No decorrer da entrevista, ela fez três interrupções, expressando sua preocupação pelo fato de a mãe permanecer tanto tempo longe do filho. Ainda assim, T8 manifestou seu desejo em dar continuidade à pesquisa; conversou abertamente sobre a espera da morte do filho para os próximos dias, mas advertiu não ter contado nada para Silvana. Ela agradeceu inúmeras vezes pela oportunidade de poder contribuir com o estudo. Ao término, a sua ex-patroa nos procura, sem T8, com a preocupação de nos informar que já havia preparado tudo para o enterro, escolhido e comprado o caixão, além de ter contratado os serviços de transporte funerário. Não haveria espaço nem tempo para rituais.

Vinícius faleceu 14 dias após a entrevista, na enfermaria, em companhia da mãe. 


\section{Família 9}

A família reside em Diadema. A mãe, W9, 39 anos, trabalhava como diarista e deixou o emprego para dedicar-se aos cuidados da filha. Está separada do pai da criança, Z9, 37 anos, que trabalha como garçom. Eles possuem quatro filhas: Sueli, 19 anos, Marli, 11, Suelyn, nove, que é diabética, e Marta, com dois. A avó materna é a provedora financeira da família neste momento.

Marta foi diagnosticada com neuroblastoma há um ano, evoluindo com metástases múltiplas. No momento da entrevista, recebia terapia paliativa exclusiva, continuava sendo acompanhada pela oncologia e pelo grupo de cuidados paliativos há quatro meses.

Consoante informações fornecidas pela mãe, há mais de seis meses não tem contato com o ex-marido. Ela teve de conciliar o acompanhamento médico de Suelyn com o tratamento de Marta. Conseguiu que ambas fossem atendidas no mesmo serviço.

A entrevista foi realizada com a mãe durante a internação de Marta.

\section{Família 10}

A família, procedente de Barueri, é constituída pelo pai, Q10, 30 anos, ajudante de pedreiro e provedor financeiro da casa, pela mãe, R10, 31 anos, e pelos filhos do casal: Rita, oito anos, que estudava até a doença ser descoberta, Ângelo, dois, e Cristiano, um ano.

Rita foi diagnosticada com leucemia linfoide aguda aos sete anos. Apesar do tratamento, houve evolução com progressão da doença e metástases ósseas. A mãe trabalhava como vendedora, mas largara 0 emprego há três meses após piora da doença de Rita. No momento da entrevista, a criança estava sendo acompanhada pelo grupo de paliativos há dois meses. Contou-se apenas com a participação da mãe na entrevista, sendo esta realizada em uma sala de reuniões da enfermaria onde a criança estava internada. 


\section{Família 11}

A família mora em Guarulhos e é composta pelo pai, R11, 46 anos, aposentado, mas trabalhava como metalúrgico, pela mãe, $\$ 11,45$, dona de casa, pelo filho, Mauro, 17, estudante do terceiro ano do Ensino Médio, e pela filha, Diana, 12 anos, falecida em 2009.

Diana foi diagnosticada com osteossarcoma em 2003, quando foi dado início ao tratamento. Em 2008, aos 11 anos, apresentou recidiva da doença com metástases múltiplas. De acordo com a mãe, o local de moradia, por estar situado na região periférica da cidade e de difícil acesso para o transporte público, dificultou muito, durante o período de tratamento, a locomoção para os atendimentos de rotina e seguimento da doença. Diana veio a falecer aos 12 anos, no hospital, em companhia da mãe, segundo a qual, a criança permaneceu em acompanhamento com o grupo de cuidados paliativos por um ano.

A entrevista foi na casa da família e contou com a presença dos pais de Diana. S11 insistiu que a entrevista fosse em sua casa para que se pudesse conhecer um pouco sobre a sua filha: o local onde ela morou, seus pertences, uma vez que não houve oportunidade de conhecê-la em vida. Assim, persistiu em mostrar as fotos de Diana, seu cachorro e quarto, que continuaram praticamente da mesma forma como ela os deixara, pois lhes faltou coragem para se desfazerem de muitos dos objetos pertencentes à filha.

A mãe agradeceu a oportunidade de ter podido falar sobre a filha e a respeito de tudo que passaram neste árduo período, que culminou com a morte de Diana. S11 revelou que aceitou participar da entrevista por acreditar que o seu sofrimento e o da filha poderiam ajudar outras famílias que vivenciavam a mesma situação ou outra de uma forma diferente, com menos dor e sofrimento.

A entrevista foi realizada com os pais um ano e meio após a morte da criança. 


\section{Família 12}

A família reside em São Paulo, compreende o pai, W12, 44 anos, que trabalha como vendedor, a mãe, Z12, 41, à época da descoberta da doença da filha, era faxineira, tendo de deixar o serviço para poder cuidar dela (hoje trabalha em uma creche municipal) e pelos filhos: Judite, 12 anos, Frederico, 20, Gabriela, 17, e Amanda, 11. Z12 mora com os filhos na casa de seus pais desde a separação do marido, que se deu em 2009.

Judite foi diagnosticada com osteossarcoma de tíbia em março de 2007, realizando amputação do membro em dezembro do mesmo ano. Em janeiro de 2010, apresentou sarcoma de pâncreas, que evoluiu com metástases múltiplas. Ela faleceu aos 13 anos, internada, em companhia de sua mãe.

Z12 relata ter perdido o seu pai em virtude de complicações de um acidente vascular cerebral e que permaneceu com sequelas devido a doença; ficou acamado e, por mais de um ano, recebeu cuidados domiciliares da família. Ele faleceu no hospital em consequência de outras complicações decorrentes também da doença. Passados dois meses, perdeu sua filha Judite.

Somente Z12 participou da entrevista na Escola de Enfermagem. Ao chegar, disse que considerava aquele dia muito importante para ela e que estava feliz, porque conseguira retornar às proximidades do Hospital das Clínicas pela primeira vez após a morte de Judite, considerando que este era mais um passo de sua caminhada que estava sendo dado desde a época do óbito. Se dispôs, desde o início, em participar da pesquisa, revelando sentir-se bem em falar sobre a filha e, com isso, poder tentar ajudar outras famílias que possam experienciar o mesmo sofrimento vivido por ela. Era um dia repleto de lembranças e fatos que a marcaram muito, mas era um desafio voltar e sentir que superara mais este obstáculo em sua vida. Por isso, estava orgulhosa de si naquele momento. Sabia que para isso tinha contado com a ajuda espiritual da filha. Ela reforça que falar sobre a filha lhe é muito gratificante. A conversa durou um longo período e, de acordo com Z12, ela nem percebera o tempo passar.

A entrevista aconteceu dez meses após a morte da criança. 


\section{Família 13}

A família, residente em Santana, distrito localizado na zona norte de São Paulo, é constituída pelo pai, Z13, 55, autônomo, pela mãe, W13, 54, dona de casa, e pelos filhos: Antônio, 30 anos, Regina, 28, casada e mãe de uma filha de oito anos, Renato, 25, e Ronaldo, 20.

Ronaldo recebeu o diagnóstico de neuroblastoma aos 14 anos e enfrentou diversos tratamentos e recidivas da doença, evoluindo com metástases múltiplas, vindo a falecer em 2009. Segundo a mãe, foi acompanhado pelo grupo de paliativos por aproximadamente um ano.

A entrevista, por insistência de W13, foi realizada na Escola de Enfermagem. O motivo desta preferência deveu-se ao fato de que retornaria para as proximidades do Hospital das Clínicas pela primeira vez após a morte do filho e considerou isto uma conquista. Ela dissera ter falado sobre a entrevista para o marido e seus outros filhos, mas que eles se recusaram a participar. Ela acredita ser difícil para eles aceitar o que aconteceu, razão pela qual não conseguem falar sobre o assunto. A entrevista foi realizada dois anos após a morte de Ronaldo.

\section{Família 14}

A família mora em Guarulhos. Os pais de Janaína separaram-se durante a sua doença. A mãe, W14, 25 anos, auxiliar de enfermagem, não trabalhava desde o nascimento da filha e se dedicava todo o seu tempo exclusivamente aos seus cuidados. O pai, V14, 23 anos, é vendedor. O casal possui mais uma filha, Elizabete, dois anos.

Janaína era portadora de mielomeningocele e paralisia cerebral. Foi diagnosticada desde o nascimento e, quando se seu falecimento, estava internada em companhia de sua mãe. Como tinha traqueostomia, era dependente de oxigênio e se alimentava por gastrostomia. A maior parte de sua vida se deu em ambiente hospitalar.

A entrevista foi realizada com a sua mãe, que relata que o ex-marido não participara da doença da filha e por isso nem the comunicara sobre a pesquisa, comentou apenas com sua mãe, avó da criança, que preferiu não participar, para não relembrar de fatos ocorridos durante a doença e morte da neta. 
W14 demonstrou muito interesse e entusiasmo em participar da pesquisa e poder colaborar com outras pessoas ao contar sua história e experiência desta difícil etapa de enfrentamento da doença de Janaína. A entrevista foi realizada um ano após o seu falecimento, que se deu aos 3 anos.

\section{Família 15}

A família reside em Barueri e é formada pelo pai, Q15, 53 anos, motorista de ônibus, pela mãe, R15, 52 anos, dona de casa, pela filha Mirian, 16 anos, e pelo filho Júlio, falecido em 2005 aos 15 anos.

Júlio era portador de xeroderma pigmentoso desde 1992, aos dois anos. Em 2001, foi diagnosticado com Linfoma não Hodgkin, sendo submetido a tratamento quimioterápico. Em 2004, recebeu outro diagnóstico: de carcinoma epidermoide refratário à terapêutica. Conforme documentado em prontuário médico, não havia possibilidade terapêutica de cura, por este motivo sendo encaminhado ao grupo de cuidados paliativos em agosto de 2004, permanecendo nove meses sob o acompanhamento deste grupo, sendo internado um dia antes de sua morte, com quadro álgico.

Mirian, hoje com 16 anos, também é portadora de xeroderma pigmentoso e faz acompanhamento ambulatorial com as equipes da dermatologia, plástica e cuidados paliativos. Com o grupo de paliativos, iniciou o acompanhamento após a morte do irmão.

A mãe refere seu sofrimento em ter visto o filho mais velho sofrer tanto com a doença e ter outra filha com a mesma patologia; por esta razão, busca fazer de tudo para que não ocorra o mesmo com Mirian; diz procurar espelhar-se no tratamento realizado pelo filho e, com isso, retirar as lições aprendidas e fazer, melhor, ainda, pela filha - ela sempre foi a cuidadora principal dos dois filhos.

Após o falecimento de Júlio, mãe e filha receberam apoio para o luto pelo grupo de cuidados paliativos, com planos de cuidados específicos para as necessidades apresentadas, como acompanhamento psicológico e terapias de suporte, segundo relato da própria mãe.

A entrevista aconteceu seis anos após o óbito de Júlio. 


\subsubsection{Coleta de dados}

O início da coleta de dados em que se utiliza a Teoria Fundamentada nos Dados focaliza-se apenas na questão básica do estudo. O pesquisador deve estar atento para esse início, buscando compreender o rumo que o estudo está tomando em função dos dados coletados e analisados simultaneamente (Strauss e Corbin, 2010).

Como um movimento inicial para conhecer a dinâmica do local, entender as estruturas organizacional e comportamental do contexto em que coletaria os dados e realizar a aproximação inicial com a criança/adolescente em cuidados paliativos e sua família, decidiu-se, juntamente com a coordenadora do grupo de cuidados paliativos, pela inserção da pesquisadora na equipe como enfermeira visitante. A pesquisadora era apresentada às famílias como enfermeira e aluna de pósgraduação vinculada a um grupo de pesquisa pertencente à Escola de Enfermagem da Universidade de São Paulo. Nesse sentido, houve um acompanhamento voluntário em relação às atividades semanais dos membros da equipe, às consultas ambulatoriais e visitas hospitalares, o que permitiu realizar observações relevantes para o andamento da pesquisa, tais como:

- Início do acompanhamento da família e criança pelo grupo.

- Interação entre membros da equipe de cuidados paliativos com a criança e a família.

- Interação entre os membros da própria equipe de cuidados paliativos.

- Situações de cuidado à criança e à família quando acontecia a piora de prognóstico.

- Interação entre as crianças e seus familiares.

O período de coleta de dados compreendeu-se entre janeiro de 2010 a março de 2011 e novembro de 2011 a janeiro de 2012. As estratégias adotadas para tal coleta foram: a observação participante, a entrevista semiestruturada e a consulta ao prontuário clínico dos pacientes. Estes são considerados recursos importantes para compreensão da experiência familiar. 
A observação participante procura acompanhar o que é expresso pelas linguagens verbal e não verbal, a fim de indicar o caminho para dar início às entrevistas. É uma estratégia que leva o pesquisador a se envolver na situação estudada e auxilia na percepção dos detalhes não contados ou verificados no decorrer da entrevista. A observação é a estratégia que leva o pesquisador a se envolver na situação estudada; além disso, faz que ele se aproxime da perspectiva dos sujeitos, uma vez que acompanha suas experiências e tenta apreender o significado que atribuem à realidade e às suas próprias ações (Ludke e Andre, 1986).

Essa fase possibilitou ampla visão do contexto, no qual a família vive sua experiência, como e com quem interage, como se comporta e reage diante de estímulos ou de situações pertinentes naquele momento e auxiliou na configuração dos grupos amostrais. Os dados adquiridos por essa estratégia foram denominados "notas de observação", como revelam os exemplos a seguir:

Durante uma visita da equipe de cuidados paliativos à enfermaria, presenciou-se no quarto a seguinte situação: enquanto a médica da equipe de cuidados paliativos conversava com a médica da oncologia sobre os exames laboratoriais e a possibilidade de transfusão sanguínea, a mãe debruçou-se sobre a cabeceira da cama do filho, que dormia no momento, e começou a lhe fazer "cafuné" nos cabelos, permanecendo em silêncio por uns instantes; a seguir, suspirou profundamente e the disse baixinho aos ouvidos: "Tenha fé, meu filho, que nós iremos vencer essa batalha. Não desiste!"

(Nota de observação, enfermaria de oncologia, 24/3/2010)

$\mathrm{Na}$ sala de espera, quatro mães conversavam enquanto aguardavam pela consulta com o grupo de cuidados paliativos. Uma delas contava sobre sua tristeza ao saber que uma criança, que era acompanhada pelo grupo de paliativos, falecera; revela que a conhecia e que era portadora da mesma patologia de seu filho. Ela olha para o final do corredor, onde o seu filho desenhava junto às demais crianças, voluntárias e recreacionistas do hospital e relata ter muito medo de perdê-lo em breve também. A criança era 
portadora de epidermólise bolhosa. As mães que a escutavam procuraram encorajá-la a não pensar dessa forma, porque as crianças são diferentes e o filho dela poderá reagir melhor ao tratamento proposto.

(Nota de observação, ambulatório da Vnidade de Dor e Cuidados Paliativos, sala de espera, 25/11/2010)

Durante atendimento ambulatorial, quando o seu filho saíra do consultório com uma das médicas para uma avaliação com a dentista, a mãe questiona a outra médica sobre a progressão da doença e o aparecimento de novos "caroços" pelo corpo do filho. A médica the explica sobre o avanço da doença e que os "caroços", na verdade, eram tumores que estavam se espalhando. A mãe começa chorar e lhe questiona o que iriam fazer a partir de agora, porque não queria ver o filho sofrendo; combinam que falariam e discutiriam o caso junto com a equipe da oncologia e que depois conversariam. Ela pede que nada seja dito ao filho por enquanto. A criança retorna com a outra médica e a mãe logo muda de assunto, perguntando 0 que o dentista dissera e que ele contasse para as doutoras que os avós o visitariam no final de semana.

(Nota de observação, ambulatório da Unidade de Dor e Cuidados Paliativos, oncologia, 3/2/2011)

Durante a entrevista, o celular da tia tocou. Ela atendeu. Ao desligar, conta-nos que brigara com o sobrinho, pelo fato de ele ter-Ihe ligado para lembrá-la que estava quase na hora de tomar o remédio (a químio via oral) e Ihe informou que não o tomaria por ser "muito amargo". Ela briga com ele e Ihe relata a necessidade de ter de administrá-lo e que o próprio pai o faria, tendo em vista ela estar ocupada. Ele se recusa a tomá-lo com o pai e combinaram que, assim que terminasse a entrevista, ela mesma the daria a medicação. O sobrinho não quis participar da entrevista e estava na casa de outra tia paterna, vizinha à residência onde estava sendo realizada a entrevista. 
A entrevista foi a segunda estratégia adotada. Para o seu desenho, seguiu-se a recomendação de Rubin e Rubin (1995). Os autores sugerem um plano flexível, interativo e contínuo, de modo a permitir a adaptação das questões de acordo com o avanço do estudo, a mudança do plano de amostragem e do foco da entrevista individual e a melhora do próprio desenho no decorrer da pesquisa, sugerindo que sejam incluídas novas perguntas posteriormente.

Esta técnica está intimamente relacionada com algumas premissas do Interacionismo Simbólico, pois, de acordo com Flick (2009), as pessoas refletem sobre suas vidas conferindo significados aos eventos e essa forma de produção de sentido pode ser acessada para se entender as questões dessa reflexão por meio de entrevistas qualitativas. Em uma destas, o pesquisador não é neutro, distante, nem deixa de se envolver emocionalmente. A empatia, sensibilidade, sinceridade e o humor são instrumentos importantes para a entrevista. Rubin e Rubin (1995) afirmam que a neutralidade não permite suficiente empatia para elucidar histórias pessoais ou descrições em profundidade. Nessas situações, é preciso explorar detalhes para clarificar a ideia que está sendo dita.

Os referidos autores ressaltam, ainda, um aspecto fundamental, qual seja: o entrevistador qualitativo deve aprender a reconhecer e explorar palavras que tenham conotações e significados simbólicos àqueles que estão sendo estudados. Neste caso, é necessário explorar detalhes para clarificar o que está sendo dito.

As entrevistas foram gravadas e tiveram duração aproximada de 40 a 150 minutos. A pergunta norteadora da pesquisa para os familiares foi: "Conte-me como é para você cuidar de sua criança/adolescente em cuidados paliativos em casa?" As entrevistas foram conduzidas simultaneamente com a análise dos dados, o que inspirou novos questionamentos, tais como: "Como é o dia a dia com o seu filho em cuidados paliativos? Quem te ajuda nos cuidados? O que é mais difícil? $\mathrm{O}$ que é mais fácil? O que vocês conversam sobre a doença? Como vocês imaginam o futuro?" 
O familiar livrou-se de qualquer constrangimento para poder contar sua experiência da maneira como fizesse mais sentido para ele. $O$ foco era retomado sempre que julgado necessário.

À medida que as categorias se formavam, novas questões foram acrescentadas, a fim de serem esclarecidas as ideias trazidas pelos entrevistados, como: "O que você pensou quando se deparou com a nova situação de sua criança? Em que momento percebeu que seu filho estava em cuidados paliativos?"

Assim, as perguntas subsequentes foram formuladas a partir de frases como: "Diga-me o que você pensa sobre..." ou "Estou interessada em ouvir sobre...", com o firme propósito de encorajar cada um dos participantes para contarem suas vivências em seu próprio estilo. De acordo com Strauss e Corbin (2008), frases dessa natureza propiciam mais espaço para que os entrevistados respondam em termos do que lhes é mais relevante.

Como estratégia para auxiliar no desencadeamento e desenvolvimento da entrevista, preencheu-se a Ficha da Família (Anexo A), onde continham informações sobre a unidade familiar, a situação de doença vivenciada e os instrumentos integrantes do Modelo Calgary de Avaliação da Família: genograma e ecomapa. Ambos têm sido amplamente utilizados em pesquisas qualitativas com famílias no campo da Enfermagem (Wright e Leahey, 2002).

A entrevista familiar foi iniciada com a elaboração do genograma, com o intuito de estabelecer um retrato da família, ajudar a entender quem são os seus membros e como estão relacionados, além de auxiliar como um "quebra-gelo" com os participantes (Wright e Leahey, 2002). Ele é uma ferramenta básica para explorar a perda em uma família, oferecendo um contexto para que façam perguntas detalhadas sobre a sua reação frente às perdas (Walsh e McGoldrick, 1998).

Foi construído um genograma trigeracional, sempre que possível, uma vez que alguns informantes desconheciam detalhes dos familiares do esposo, para cada família, o que permitiu saber quem eram os seus membros, qual lugar ocupavam, quando e como morreram e quais as outras perdas o sistema já vivenciou. 
O ecomapa visa obter dados importantes sobre os recursos familiares, os quais são aspectos externos à família (família extensa, amigos, vizinhos, comunidades, instituições religiosas etc.) que a ajudam, de alguma forma, a enfrentar a experiência (Feeley e Gottlieb, 2000).

A utilização destes instrumentos facultou uma rápida visualização de conexões e interações significativas, que juntamente com os relatos obtidos nas entrevistas proporcionaram o desenvolvimento de novas perguntas, as quais permitiram alcançar maior compreensão da experiência.

Foi utilizada como estratégia para aumentar os dados obtidos, a partir de uma perspectiva sistêmica, uma adaptação das "questões circulares", proposta por Wright e Leahey (2002) e sugerida por Bousso (2006) para avaliação da família em pesquisa. Tais questões elucidam as diferenças entre os membros familiares. De acordo com Bousso (2006), o objetivo para o seu uso em pesquisa é incrementar a natureza sistêmica dos dados e revelar mais sobre as interações e comportamentos que poderiam ser evidenciados em entrevistas individuais com aquele membro.

A utilização deste tipo de questão é uma estratégia para que o entrevistado possa falar sobre os membros ausentes. Assim, foram incluídas perguntas como: "O que você pensou quando foram informados sobre a mudança do foco de tratamento do curativo para o paliativo?" Em seguida: "O que você acha que seu marido pensou quando vocês foram informados sobre os cuidados paliativos?" Depois: "O que você acha que seus pais/filhos pensaram?"

Para completar os dados resultantes das entrevistas, das observações e auxiliar no preenchimento da Ficha da Família, recorreu-se à pesquisa dos prontuários clínicos, para que fosse possível adquirir algumas informações, como: diagnóstico, tempo de diagnóstico, encaminhamento para a Unidade de Dor e Cuidados Paliativos, tempo de acompanhamento na Unidade e o que havia registrado relacionado às informações que a equipe de saúde dera às famílias referentes aos cuidados paliativos e prognóstico das crianças/adolescentes.

Entrevistas qualitativas com famílias podem se tornar "intensas" e mesmo os participantes, quando já estiverem esclarecidos, poderão se 
perceber falando ou expressando mais do que gostariam. Neste estudo, reforçou-se à família, no final de cada entrevista, que ela poderia refutar sua participação na pesquisa a qualquer momento sem prejuízo algum. Mas nenhuma delas solicitou interrupção.

\subsubsection{Desafios e dificuldades encontrados durante a coleta de dados}

Entrevistar famílias que possuem um membro em cuidados paliativos é um grande desafio. É necessário reconhecer que os participantes do estudo estão submetidos a um considerável período de estresse. Assim, é essencial que o pesquisador tenha habilidade para conduzir as entrevistas neste contexto. Os membros familiares beneficiam-se quando o pesquisador consegue conduzir as entrevistas com sensibilidade e discrição (Davies et al., 1995). Um dos maiores desafios durante todo o processo da pesquisa foi encontrar famílias que atendessem os critérios de inclusão e concordassem em participar. Em determinadas situações, a mãe consentiu participar, mas, após consenso com o marido, desistiu para proteger a criança de uma provável exposição.

Outros problemas encontrados foram que, em certas situações, a família concordou em participar, mas como a doença progredia rapidamente, a criança debilitava-se na mesma proporção, com sintomas não controlados, o que inviabilizava a realização das entrevistas. No decorrer da pesquisa, algumas faleceram, o que culminou com a recusa de seus familiares em participar da pesquisa. Em outros casos, não houve tempo hábil para convidá-las, tendo em vista que faleciam logo após a sua inclusão no grupo de cuidados paliativos, fato ocorrido, sobretudo, com crianças/adolescentes portadores de afecções oncológicas.

Solicitar a participação de vários componentes familiares coloca demandas adicionais para quem enfrenta a situação de ter um de seus integrantes em cuidados paliativos, o que dificulta encontrar famílias dispostas a participar desses estudos. Nessa fase de suas vidas, a solicitação de participação em entrevista sobre o tema pode acarretar-lhes 
sobrecarga, justificando a sua não aceitação (Davies et al., 1995).

Outra dificuldade encontrada foi com relação ao acesso aos demais integrantes familiares. As crianças são acompanhadas quase sempre pela mãe, que representava o restante da família para nosso contato. Houve baixa participação dos outros membros familiares na pesquisa. No geral, as mães relataram não haver disponibilidade para que os demais integrantes da família participassem da entrevista em virtude da dificuldade de conciliação de horário, incluindo também os finais de semana. Segundo elas, muitos de seus membros optaram também por não fazê-la, apesar de participarem da rotina de cuidado; isto porque não se sentiam em condições de falar sobre a experiência de se encontrar perdendo a criança para a doença. Algumas mães, ainda, decidiram não convidar outras pessoas da família, devido ao fato de não conversarem sobre o estado de saúde do filho ou porque não as consideravam como família, uma vez que eram totalmente ausentes de todo este processo e da experiência enfrentada por elas no período da doença.

As crianças e adolescentes em cuidados paliativos que possuíam condições clínicas e de desenvolvimento e demais crianças da família, como seus irmãos, foram excluídos da pesquisa pelas próprias mães, apesar de 0 convite ter sido estendido a elas. Somente quatro mães permitiram que elas fossem abordadas quanto à sua participação, mas se recusaram a fazê-lo.

\subsubsection{Análise dos dados}

O primeiro passo para o início das análises do material foi a transcrição na íntegra das entrevistas realizadas com os integrantes familiares. Elas foram analisadas de acordo com o método comparativo constante, que envolve comparar categorias em busca de conceitos similares ou diferentes para revelar possíveis propriedades e dimensões, desenvolvendo a conceitualização teórica (Strauss e Corbin, 2008).

No decorrer de todas as etapas de análise, foram desenvolvidos memorandos, com a finalidade de registrar as sessões analíticas, com pensamentos, interpretações, questões e direções para a coleta adicional 
dos dados. O memorando é um procedimento auxiliar para o desenvolvimento da teoria, é o registro escrito do processo de análise dos dados, representando o pensamento abstrato (insigths) que se tem sobre eles (Strauss e Corbin, 2008).

A seguir, apresenta-se um exemplo de memorando sobre a categoria "Não podendo aceitar a nova condição":

"No momento que a família recebe informações sobre o prognóstico de sua criança/adolescente e a falta de possibilidade terapêutica de cura, a primeira reação é colocar em dúvida a veracidade das informações recebidas, a sua prioridade é manter o filho vivo a qualquer custo. Dessa forma, parece iniciar um movimento de busca por estratégias que permitam alterar o prognóstico da criança, continuar seu tratamento e alcançar a cura do filho".

A codificação aberta constitui-se a primeira etapa da análise. Nesse momento, o texto de cada entrevista é fragmentado em pequenos trechos e examinado linha por linha, de modo a expor pensamentos, ideias e significados. A todo o momento, o pesquisador deve perguntar-se: "O que é isto? O que isto representa? O que está acontecendo com a família aqui?" (Strauss e Corbin, 2008).

Ao serem respondidas estas perguntas, será possível extrair as primeiras propriedades e a dimensão da experiência para fazer a codificação. Desta feita, os dados foram separados em partes distintas, rigorosamente examinados, permitindo a identificação das primeiras propriedades que compuseram a experiência - os códigos, conforme exemplificado no Quadro 2. 


\section{Quadro 2 - Exemplo de codificação aberta}

\begin{tabular}{|c|c|}
\hline Trecho da Entrevista & Códigos \\
\hline $\begin{array}{l}\text { "Porque assim, a gente não sabe até } \\
\text { que ponto ele absorveu tudo o que foi } \\
\text { falado pra ele, porque ele sabe de } \\
\text { tudo, não foi escondido nada dele. A } \\
\text { gente não esconde nada, lógico que } \\
\text { assim, eu acho que na cabeça } \\
\text { dele,ele, ele não aceite a situação, } \\
\text { entendeu, ele acha, até esses tempos } \\
\text { atrás ele tava achando que poderia ser } \\
\text { operado ainda... então assim, é muito } \\
\text { difícil pra vc chegar pra uma criança e } \\
\text { fala "oh! Não dá pra operar mais, mas, } \\
\text { mas a gente tenta (...)" }\end{array}$ & $\begin{array}{l}\text { Não sabendo o que realmente } 0 \\
\text { sobrinho entende de sua situação } \\
\text { Não sabendo o que o sobrinho } \\
\text { absorveu de tudo o que lhe foi dito } \\
\text { sobre sua situação } \\
\text { Não escondendo nada do sobrinho } \\
\text { sobre sua doença } \\
\text { Achando que na cabeça do sobrinho } \\
\text { ele não aceite a piora de sua situação } \\
\text { Sobrinho achando até pouco atrás que } \\
\text { ainda poderia ser operado } \\
\text { Sendo muito difícil chegar para uma } \\
\text { criança e dizer que ela não poderá } \\
\text { mais ser operada } \\
\text { Tentando falar da situação com o } \\
\text { sobrinho apesar de ser um tema difícil } \\
\text { para se lidar com uma criança }\end{array}$ \\
\hline
\end{tabular}

A seguir, os dados (eventos, acontecimentos, objetos e ações/interações) foram comparados em busca de similaridades e diferenças e agrupados sob conceitos mais abstratos, denominados categorias, conforme ilustrado no Quadro 3. 


\section{Quadro 3 - Exemplo de categorização}

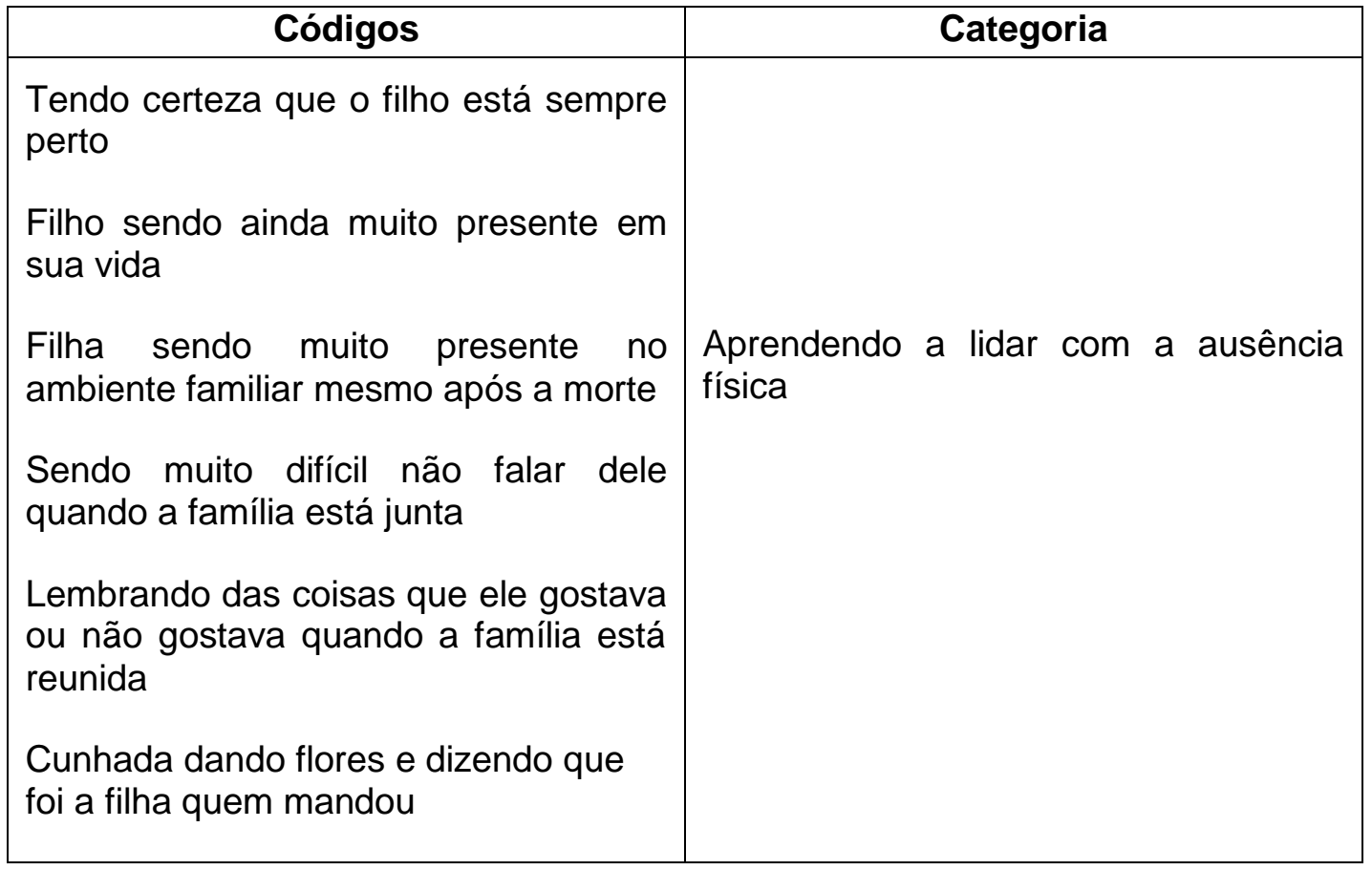

A segunda etapa da análise é chamada codificação axial e se trata do processo de relacionar categorias às suas subcategorias, com a finalidade de gerar explicações mais precisas e completas sobre os fenômenos. Como as associações entre categorias podem ser muito implícitas, Strauss e Corbin (2008) recomendam o desenvolvimento de um esquema que possa ser utilizado para organizar as conexões emergentes.

Glaser (1978) apresenta 18 esquemas para auxiliar a análise dos dados na etapa da codificação axial, denominados "famílias": seis Cs, processo, família de grau, de dimensão, de tipo, estratégica, interativa, de identidade de si, de ponto de corte, de objetivo principal, cultural, de consenso, de linha principal, teórica, de ordenação e elaboração, de unidade e de leitura e modelos.

Nesse estudo, utilizou-se o tipo denominado "processo" para a codificação axial. Strauss e Corbin (2008) o definem como uma série de sequências evolutivas de ação/interação que ocorrem no tempo e espaço, mudando ou permanecendo inalteradas em alguns momentos, em resposta à situação ou ao contexto. 
Dessa maneira, o processo nos dados é representado por acontecimentos e fatos que podem ou não ocorrer em sequências contínuas. Nesse sentido, estágios ou fases podem não ser a melhor maneira para explicá-las. Por esse motivo, seguiu-se a recomendação de Strauss e Corbin (2008), nomeando de "subprocessos" as aquelas que compõem o processo. Para os autores, "subprocessos" são as táticas individuais, as estratégias e ações rotineiras empreendidas pelas pessoas durante o processo.

A codificação seletiva constitui-se a terceira etapa da análise, onde se buscou integrar e refinar a teoria. Assim como as demais etapas da análise, essa integração é uma interação entre o analista e os dados, pois inclui a evolução do pensamento que ocorre com o tempo por meio da imersão nos dados e o conjunto de resultados que foram registrados em memorandos e diagramas.

Assim, quando se atingiu a saturação teórica, não mais surgindo novas propriedades, dimensões ou relações durante a análise, foi possível identificar a categoria central, aquela que representou o tema principal da pesquisa por reunir todas as categorias importantes para formar um todo explanatório.

Como a meta do projeto era a construção de uma Teoria Fundamentada nos Dados, os resultados são apresentados como um conjunto de conceitos inter-relacionados mediante a redação de um enredo (Strauss e Corbin, 2008).

Por conseguinte, ao final de todas as etapas que compõem o método da Teoria Fundamentada nos Dados, foi possível propor um modelo teórico explicativo do processo da experiência da família da criança/adolescente em cuidados paliativos.

Elaborou-se um diagrama facilmente compreensível para ilustrar o modelo teórico desenvolvido, sem a pretensão de que ele capte toda a complexidade apresentada na redação do enredo. Optou-se por um diagrama simples, que, de acordo com Strauss e Corbin (2008), facilita o seu entendimento e uso. 


\subsubsection{Atendendo aos aspectos éticos}

A coleta de dados iniciou-se mediante parecer favorável do Comitê de Ética em Pesquisa, conforme a Resolução n ${ }^{\circ} 196$, de 10 de outubro de 1996, do Conselho Nacional de Saúde (CNS), que aprovou as diretrizes e normas regulamentadoras de pesquisas envolvendo seres humanos (CNS, 1996).

Esse projeto foi submetido sob o processo $n^{0} 739 / 2008$, ao Comitê de Ética da Escola de Enfermagem da Universidade de São Paulo (CEP EE/USP), o qual é aprovado pela Comissão Nacional de Ética em Pesquisa do Ministério da Saúde (Conep/MS) e registrado no Sistema Nacional de Informação sobre Ética em Pesquisa envolvendo Seres Humanos (Sisnep). O projeto foi aprovado em sessão do dia 28/5/2008 (Anexo B).

A instituição envolvida como campo de coleta de dados foi consultada quanto à nova submissão em comitê próprio e solicitou que o projeto fosse também submetido ao seu próprio Comitê de Ética, sendo, assim, submetido também à análise do Comitê de Ética em Pesquisa do Instituto da Criança do Hospital das Clínicas da Universidade de São Paulo, recebendo parecer favorável, sob o processo de registro no 748/40/2008 na data de 15/08/2008 (Anexo C).

Antes de se dar início à coleta de dados, todos os participantes foram esclarecidos quanto aos objetivos do estudo, procedimentos e métodos de coleta dos dados, sobretudo sobre a ciência do uso do gravador para as entrevistas, à garantia de sigilo das informações, ao direito de anonimato e à liberdade em participar ou não do estudo, por meio da leitura do termo de Consentimento Livre e Esclarecido (Anexo D). Após os devidos esclarecimentos e a partir do momento em que não houve mais dúvidas em relação à pesquisa, solicitou-se autorização formal por escrito e cada participante recebeu uma cópia do referido termo.

A pesquisa qualitativa com famílias requer informações profundas e detalhadas sobre as experiências de vida dos indivíduos, as quais vêm acompanhadas de fortes memórias e emoções, em especial, quando são pesquisadas situações que envolvam dor e sofrimento, em especial o caso do viver com a doença grave e limitadora do tempo de vida da criança. $\mathrm{O}$ acesso a informações privilegiadas, que fazem parte da vida privada do 
indivíduo e da família, deve vir acompanhado pela responsabilidade e pelo compromisso de criar uma ética relacional quando do diálogo feito no decorrer da entrevista, como representá-la de forma autêntica no relatório de pesquisa (Frank, 2005).

A obrigação moral existe. Isto para que o pesquisador possa afirmar que há uma justificativa sólida para a investigação e o método de pesquisa, que vai além da curiosidade intrusiva e mais do que contar histórias tristes (Thorne e Darbyshire, 2005).

\subsubsection{Cuidados com os participantes}

Para preservar a identidade das crianças e de seus familiares, foram utilizados nomes fictícios e letras e números aleatórios, sendo omitido qualquer dado que pudesse identificá-los. A identidade deles também será preservada em futuras exposições dos resultados sobre a presente pesquisa. Os valores (culturais, sociais, morais, religiosos e éticos), hábitos e costumes dos envolvidos receberam a mesma preservação.

Nos casos em que os participantes tiveram de se deslocar ao ambulatório ou à Escola de Enfermagem da Universidade de São Paulo para exclusiva participação da pesquisa, Ihes foi garantido o ressarcimento das despesas com transporte e alimentação. Não Ihes foi oferecido ou concedido qualquer tipo de gratificação financeira. 


\section{Resultados}




\subsection{Compreendendo a Experiência da Família da Criança/Adolescente em Cuidados Paliativos}

A análise dos dados obtidos possibilitou desvendar os significados e compreender a experiência da criança/adolescente em cuidados paliativos.

As categorias identificadas e as relações teóricas estabelecidas possibilitaram o desenvolvimento de um processo analítico e explicativo das ações e interações que compõem o processo de experienciar esta situação, o qual, vivenciado pela família da criança/adolescente em cuidados paliativos, envolve a dinâmica existente entre a necessidade de:

- se definir a nova condição da criança/adolescente;

- reconhecer os cuidados paliativos como uma nova estratégia de cuidado;

- manejar a nova condição mediante ações e estratégias que permitam manter a esperança em diminuir sintomas e manter a qualidade de vida da criança/adolescente;

- ter de reaprender a viver em um mundo transformado pelas perdas.

O processo é constituído por quatro subprocessos, que representam o significado simbólico da experiência para a família da criança/adolescente, da criança em cuidados paliativos, como componentes de um processo de esperança, perdas e sofrimento não linear e nem definido por uma linha de tempo rígida. Cada subprocesso identificado foi nomeado para formar as categorias:TENDO A VIDA ESTILHAÇADA; MANEJANDO A NOVA CONDIÇÃO; RECONHECENDO OS CUIDADOS PALIATIVOS; REAPRENDENDO A VIVER.

As categorias, bem como suas subcategorias estão sumarizadas no Quadro 4. 


\section{Quadro 4 - Categorias e subcategorias que compõem o processo}

\begin{tabular}{|l|l|}
\hline \multicolumn{1}{|c|}{ CATEGORIAS } & \multicolumn{1}{c|}{ SUBCATEGORIAS } \\
\hline TENDO A VIDA ESTILHAÇADA & - Tendo o filho em cuidados paliativos \\
& - Não podendo aceitar a nova \\
& condição \\
& - Precisando manter a criança viva \\
MANEJANDO A NOVA CONDIÇÃO & - Precisando de suporte \\
& - Mantendo a criança/adolescente em \\
& casa \\
& - Engajando-se no cuidado \\
RECONHECENDO OS CUIDADOS & - Vivenciando perdas \\
PALIATIVOS & - Aprendendo a viver um dia de cada \\
& vez \\
REAPRENDENDO A VIVER & - Perdendo a parceria com o filho \\
& - Recompondo a trajetória da doença \\
& - Aprendendo a lidar com a ausência \\
& física \\
& - Não podendo dar significado à perda \\
\hline
\end{tabular}

No corpo do texto, as categorias são apresentadas em maiúsculas e em negrito. Cada uma delas é composta por subcategorias que aparecem no texto sublinhadas. Conforme preconizado pela pesquisa qualitativa, foram ilustrados os subprocessos apresentados por meio de falas dos sujeitos.

Em buscar preservar o anonimato dos participantes, cada família foi identificada por meio de números entre parênteses, que se encontra ao final dos trechos das entrevistas que ilustram e apresentam os resultados.

\section{TENDO A VIDA ESTILHAÇADA}

A experiência da família inicia-se quando a equipe médica the comunica que a criança/adolescente está fora de possibilidade terapêutica de cura e/ou que a doença progride e que, a partir daquele momento, o tratamento será exclusivamente paliativo, com o objetivo de controlar sinais, sintomas e promover melhoria ou manutenção da qualidade de vida da criança/adolescente. Desse modo, a família depara-se, pela primeira vez, de forma concreta, com a notícia de que não há mais possibilidade de cura para 
o filho, cujo estado de saúde está se agravando, a cada dia mais, em função da progressão da doença, uma vez que todos os tratamentos realizados não surtem mais efeito para contê-la. A notícia recebida pelos familiares, em um primeiro momento, de que o filho se encontra em cuidados paliativos pode ser entendida, por eles, como uma sentença de morte iminente. Assim, TENDO A VIDA ESTILHAÇADA, representa as reações da família ao se deparar com a informação da possibilidade de morte iminente do filho, a dificuldade em imaginar os desdobramentos desta situação em suas vidas e a sua impossibilidade de aceitar o fato naquele momento, precisando acreditar que ele permanecerá vivo.

A categoria TENDO A VIDA ESTILHAÇADA é representada pelas subcategorias: "Tendo o filho em cuidados paliativos", "Não podendo aceitar a nova condição" e "Precisando manter a criança viva".

\section{Tendo o filho em cuidados paliativos}

A notícia de que a criança/adolescente encontra-se em cuidados paliativos causa um impacto na experiência de doença para a família. Esta nova informação representa ter de abrir mão de tudo o que ela esperara e sonhara: a cura da criança/adolescente. "Tendo o filho em cuidados paliativos" representa as crenças dos pais sobre a condição da criança/adolescente em cuidados paliativos e sua autoavaliação da sua própria capacidade de gerir eficazmente a informação.

Para a família, a notícia de que a criança está fora de possibilidade terapêutica de cura ainda não é real. As informações de que dispõe sobre o estado clínico do filho parecem equivocadas. Ela sente-se incapaz de compreender este novo fato e se refere a ele como um sonho. Age se afastando desta realidade e, assim, se mantém distante como se tudo aquilo dissesse respeito a outras pessoas.

"Dá impressão que abre o chão e você entra dentro, é a mesma coisa! Que você não vê, que você não ouve e que você não enxerga... É uma sensação assim, como se aquilo não estivesse acontecendo com você. $\mathscr{E}$ uma coisa muito estranha! É muito assim... É muito..., não dá para descrever o que você sente na hora." (F13) 
“(..) Foi assim, a partir daquele momento" (que recebeu a notícia que o tratamento da filha não estava dando resultado), "você começa ver a situação. Parece que não é você, parece que você está vendo VOCÊ! Parece que você está vivendo a situação de fora... Você está entendendo? Então, a partir daquele momento que a doutora falou aquilo para mim, sabe que parece... que parece que te dá uma tontura. Você vê as coisas lá no fundo e as coisas vão voltando, quando as pessoas falam realmente é um buraco! É realmente um buraco! Você se vê sem chão, né?" (F12)

"Virgem Maria! Quando eu ouvi aquilo da médica, que não ia conseguir tratar mais da minha filha, que estava difícil o caso dela... Nossa..., eu nem queria ouvir mais a voz dela, eu só queria pensar que eu estava num sonho e que aquilo tudo ia passar, sabe? Nossa! Foi..., foi muito ruim! Nem sei dizer como foi, sabe?" (F9)

"Tendo o filho em cuidados paliativos" é visto pela família como um golpe imposto pela experiência da doença dele. Esta vem seguindo um tratamento e mantendo os cuidados do filho com o objetivo de cura e/ou estabilização da doença, buscando frear sua progressão e, muitas vezes, de forma abrupta percebe sua vida sendo destruída e alterada pela notícia de que o tratamento dele não está mais dando certo.

“....) aí chegou lá, deu a cacetada, falou que não dava mais. Daí..., quer dizer, igual ele falou, né? Ele ia pôr a prótese no joelho, que ele ia, né? Daí, já ia deslanchar para melhorar. Daí chegou lá, deu uma cacetada, falou que não ia mais, né?, que não tinha mais o que podia fazer. Daí para gente, né?, já piorou, mudou totalmente a cacetada foi fogo, né (...)?” (F1, mãe)

"Tendo o filho em cuidados paliativos" representa a impossibilidade da família de compreender, neste momento, que o tratamento não está dando certo e que o diagnóstico foi considerado fechado pela equipe médica.

“(...) Porque foi um tipo, assim, de clima que deu a entender que não tinha mais o que fazer, sabe?, que não estava dando certo, que não tinha químio para ela mais porque a Ana. já passou por várias quimioterapias e chegaram a falar que não tinha muita químio para ela (...). A gente entrou mesmo, entrou eи e meu marido, entramos num, num, num mundo, assim, difícil de sair, mas aí eu pensei bem, assim... Eu não sei... É meu jeito mesmo, pensei bem e falei: $\mathcal{N} a ̃ o$, tem saída! Tem saída." (F2)

“Aí eu falei: OK! E... ela falou: 'É isso!' Eu falei: É isso o quê? E ela falou: 'A Judite, ela vai embora e é dentro de poucos dias!' 'Nossa, você não tem noção... Eu falei: Ai! Eu falei: 
Está 6om! Deu aquele 6aque, né? Depois eu pensei: Que 6obagem, né? Quem é ela para falar isso, né? Eu falei: Quanta bobagem! Isso não vai acontecer com a gente!" (F12)

No início da experiência de cuidados paliativos, as informações fornecidas aos pais relacionadas aos planos futuros para o cuidado da criança/adolescente são limitadas. Eles sentem-se perdidos, sem entender ao certo o que está acontecendo nem o que acontecerá de agora em diante.

“(...) Eles me chamaram aqui, falaram que não tinha muito mais o que fazer pela minha filha, que não iam deixar ela ter dor, e não sei que lá... E eu só fiquei olhando (...) daqui para frente eu não sei o que que vai acontecer, o que que pode acontecer." (F10)

Receber informações sobre o estado crítico de saúde da criança/adolescente e a notícia de que não há qualquer possibilidade de cura levam a família a redefinir a situação. A definição inicial que ela faz a respeito da nova condição da criança/adolescente é influenciada pelo papel ocupado pela criança na vida familiar, que tem um significado simbólico e afetivo aos membros da família. Esta definição inclui a capacidade e as vulnerabilidades da criança. Neste contexto, a família revela suas crenças em relação à gravidade, prognóstico e curso da doença e a criança/adolescente é vista como frágil e vulnerável.

"Ela ficou muito debilitada e fraca com o tratamento e a doença (...). Ficou sendo uma menina especial para a gente. Eu tinha muito cuidado com ela (...)" (F10)

“...) se eu pudesse, eu fazia uma pirâmide de vidro para ninguém encostar nela, ninguém. Para mim, ela é uma boneca de porcelana (...)." (F3)

"Noão é fácil você ter uma pessoa que tem 15 aninhos (...) mas ele é um bebêe e vai ser bebê sempre (...). Cuidar dele tem que fazer tudo delicado, os ossinhos dele são fraquinhos." (F6, mãe)

Ao definir a criança como frágil e vulnerável, a família se dá conta que a criança/adolescente não pode realizar algumas atividades como as demais com a mesma idade sua. A família relata seu sofrimento ao ver o filho diferente das outras crianças, necessitando de cuidados especiais, sendo dependente e, muitas vezes, não conseguindo realizar atividades cotidianas. Esta definição da criança/adolescente faz com que os pais transformem a criança em cuidados 
paliativos como o foco de sua atenção e reforça seus sentimentos de perda de ver o filho se desenvolver como qualquer criança de sua idade.

“(...) a gente vê uma criança de 15 anos correndo, já namorando, fazendo tudo que tem direito, né? Ele, tadinho, é um bebê (...), cérebro dele não desenvolveu, é um cérebro de criança mesmo, de criança pequena, então não desenvolve. Então, para a gente que é mãe, a gente no fundo, no fundo, a gente tem um pouquinho de (...) Poxa, deveria meu filho, com 15 anos, estar fazendo tudo isso." (F6, mãe)

“(...) muitas coisas ela deixa de fazer porque está com dor. Ela deixa de ir para a escola (...). Se ela tivesse uma dorzinha assim, ela falava: 'Amanfã eu aguento ir para a escola, mãe. Hoje eu não vou, mas amanhã eu vou'. Ela não pode ir mais para a escola, ela não sai de dentro de casa porque ela está muito fraquinha e ainda está com dor (...), não come, com dor, ela não faz nada, na verdade." (F3)

A família acompanha todo o sofrimento e as adversidades enfrentados pela criança/adolescente durante toda a trajetória da doença. Ao falar sobre o seu filho, que está em cuidados paliativos, vai alterando sua crença de que ele seja tão frágil e passa a observá-lo e a colocá-lo como forte, lutador e se esforça para revelar suas habilidades, características como criança e o papel central que ele ocupa na família, apesar da doença. Nestas circunstâncias, passa a defini-lo como um guerreiro. E é com base nesta definição de que o filho é um lutador que a família se apega para manter acesa sua esperança na cura da criança/adolescente. Reconhecendo o filho como um guerreiro, que sempre demonstrou sua vontade de lutar contra a doença e viver, ela busca forças para continuar acreditando que pode mudar o rumo da história e conseguir mantê-lo vivo.

“(...) ele é uma pessoa muito querida dentro da família, tem muitos amigos, assim... Ele sempre foi uma pessoa muito terrível! É muito brincalhão e agora nessa situação, a gente vê que ele corre atrás, quer melhorar, sabe? Quer sentir bem de novo." (F1, tia)

"Ah é, de como a Judite era, né? Então, era isso, ela passava isso para as pessoas, essa fé, essa esperança! 'OCha, eu sou criança, eu já passei por tudo isso, já passei por um tumor na perna, já estou terminando esse daqui na radioterapia, nada aconteceu, eu estou 6em'. É isso que ela passava para gente: CURA. Para mim, ela era o exemplo de que é possivel! Quando alguém vinha falar para mim da Judite, eu falava: Minha filha está aí de prova. Todo mundo dava o exemplo dela, entendeu?" (F12) 
“(...) do jeito que ele luta para sobreviver, a gente também sempre está lutando do lado dele, né? E ele é forte! Esse garoto é forte (...), forte mesmo." (F6, pai)

A família relembra de eventos traumáticos ocorridos no passado no decorrer da trajetória da doença, mas que também proporcionaram experiências agradáveis, uma vez que a recuperação da criança/adolescente foi possível. Dessa forma, são capazes de reconstruir a realidade que estão vivenciando e, assim, fazem uma nova definição da criança, como alguém capaz de superar adversidades. Reconhecer que o filho é forte para continuar lutando pela vida, em um momento de tão grande desamparo, parece ser importante para que a família possa enfrentar os obstáculos causados pelos estilhaços de saber que seu filho encontra-se sem possibilidade terapêutica de cura e mantenha sua esperança na recuperação da criança.

Essa determinação do filho em continuar vivendo é onde a mãe se apega para iniciar uma parceria com ele, para que possa mantê-lo vivo. Ver que ele acredita que pode se curar, vê-lo com esperanças de superar os desafios impostos pela sua doença e fazer planos para o seu futuro a impulsionam na sua determinação de continuar lutando pela vida dele.

"A gente vê que ela tem aquela força de vontade de viver, não quer desistir, não quer entregar os pontos, ela não... Ela quer viver mesmo, sabe? Por isso que eu falo: Ai meu Deus, o Senhor tem que ser muito 6om, porque..., para ter mais tempo para ela, porque acho que ela ainda tem muita coisa para fazer ainda nessa vida, muita coisa!" (F2)

"Igual ela quer estudar, quer fazer medicina (...). Hoje ela está bem, mas eu sei que ela tem uma doença que amanhã pode desandar tudo e ela ficar muito ruim e complicar e ela também sabe disso (...), mas ela não desanima! Ela estuda, ela planeja a faculdade, fica vendo que área que ela podia fazer..., porque tem lá as limitações dela de não conseguir andar direito e sentir dor e inchar, mas ela está firme na batalhinha dela. Eu vejo ela falando e me pergunto, sabe?, quem sou eu para não acreditar que ela pode conseguir isso?" (F4)

As crenças da família em relação à nova condição da criança são fortemente influenciadas pelas informações recebidas dos profissionais no decorrer da doença, bem como pelas observações dos familiares e circunstâncias factuais - quer seja a progressão de uma doença crônica para a 
qual a cura já não existia, quer seja a falha terapêutica no caso das doenças oncológicas - que levou a criança ser referida a uma equipe de cuidados paliativos em regime ambulatorial ou de internação. A convicção de que o filho vai ficar livre da doença advém das superações vivenciadas anteriormente.

"Eu sempre esperei que o Vinícius ia ser curado, não tinha dúvida nenhuma sobre isso, $e$ ouvir o que o médico me disse, que eu não ia ter meu filho curado... Nossa! (...) não foi como eu imaginei também!" (F8)

“(...) porque, puxa vida, a doutora, ela falou, eu acreditei, mas parecia que eu não estava ali naquela hora (...), você está entendendo? (...) "Ela" (a médica) "foi me falando assim, né? O tumor, ele pegou todos os espaços, não que ele pegou um órgão ou outro órgão, ele pegou, ele preencheu tudo ali dentro e de uma forma inacreditável, sabe? Em menos de um mês, ele pegou tudo (...)" (F12)

"O doutor veio conversar comigo e falou que estava entrando com cuidados paliativos para ela, e eu não sabia o que era, aí eu perguntei para ele o que era isso. Ele respondeu assim: 'São os cuidados que são dados para uma pessoa que não tem expectativa de vida, antes da morte, para não sofrer.' Foi isso que ele me explicou. Aquilo me abalou de um jeito..." (F14)

A dificuldade da família em aceitar a realidade trazida pelos profissionais é reforçada pelas vivência da trajetória da doença. Estas crianças com doenças limitantes de vida em cuidados paliativos enfrentam exacerbações, crises ou recidivas que, por várias vezes, foram contornadas. Dessa forma, a família imagina que, como antes, a doença está presente, ativa, mas que o filho conseguirá se tratar e, assim, nega a dura realidade de que não existem mais tratamentos disponíveis para a cura.

"E todas as vezes que ele tinha uma crise" (recidiva da doença), "eu falava assim: $\mathcal{N a ̃ o , ~}$ isso aí vai passar, vai passar e passava. Ele saía bem! Eu pensava que ia ser igual, né? Ia tratar, ele ia ficar bem de novo!" (F13)

A família verbaliza com entusiasmo a melhora dos quadros álgicos e a diminuição dos sintomas apresentados; em alguns casos, constata que as internações hospitalares estão menos frequentes e percebe que isto está estritamente relacionado com o aumento da disposição de suas crianças, o que a mantém, tanto quanto a criança, com esperança em continuar fazendo 
planos para o futuro, como: voltar para a escola e poder realizar atividades rotineiras, por exemplo: brincar e passear com a família, tendo, pois, o filho consigo por muitos anos ainda. A família agarra-se a cada um destes fatores para manter sua esperança e conseguir imaginar um caminho que a leve em direção a um rumo melhor, o que significa poder manter sua criança viva.

“(...) e as dores passaram. Então, já não atrapalha mais ela, dá para ela andar mais; antes, ela não podia andar muito porque tinha muito cansaço, né? Os medicamentos que entraram para dor foram excelentes para ela, né? porque ano passado ela entrou aqui com dores assim terrível, né? (...) ela já está se sentindo bem melhor, já não sofre de dor nenhuma... Então, a vida dela melhorou assim bastante, ela nem fala mais nada, ela só quer tirar remédio. A Ana, agora, não quer nem tomar mais nada, só quer tirar. Então, eu falei: É um bom sinal, né? É sinal que ela está bem, porque a Ana, quando ela não está 6em, ela mesma fala. Então, é dela, ela está muito bem agora, muito 6em! Do ano passado para hoje, está ótima, outra criança em tudo, na alimentação, em tudo, está muito 6om!” (F2)

\section{Não podendo aceitar a nova condição}

O choque emocional a esta nova informação de que o filho está em cuidados paliativos é caracterizado por sentimentos de insegurança, desconfiança, descrença e medo do que possa vir experimentar.

A necessidade em organizar e dar sentido aos eventos anteriores e a notícia dos cuidados paliativos fazem com que os familiares, especialmente a mãe, por geralmente ser a pessoa que vem acompanhando o filho desde 0 momento do diagnóstico, reavaliem os comportamentos e relacionamentos com a equipe de saúde; relembra os momentos de parceria e confiança com a equipe e, sobretudo, com o médico responsável pelo tratamento da criança/adolescente durante todo o tratamento. Os resultados positivos alcançados até então fazem com que reforcem sua ideia de que a cura ainda é possível e que, mais uma vez, a equipe de saúde conseguirá encontrar uma solução para reverter o avanço da doença.

“(...) não tinha mais químio para Judite, não tinha mais. A doutora já tinha testado todas as químios e não tinha mais o que testar de químio! (...) E eu falava: e então? Então, né? E aí, doutora? Não acaba aqui, né? Tem que ter alguma ... vamos, vamos, vamos. Aí ela falou: 'Vamos 
tentar a cirurgia!' Eu falei: Vamos embora! O tumor foi retirado, ele estava morto, ele não tinha diminuido, mas ele estava morto, ótima notícia, né? Ai ela" (médica) "falou: 'Então, vamos fazer rádio agora, vamos fazer rádio porque..., só para..., só para não ficar nenhuma dúvida. Então, vão embora para rádio, vão embora para rádio!' E ela não sentiu nada na rádio, sabe o que é nada? Ela não sentiu mal-estar, não alterou a pele dela, ela não... Nãa alterou a medicação, a fome, nada! Foi mil maravilhas! (...) e novembro terminou a rádio dela, 16 de novembro. Aí passou uns dias, a Judite estava de alta já! (...) Depois que voltou tudo de novo, mas a doutora fez, sabe? Ela tentou, né?, de tudo, né? .... todas as coisas que ela tinha disponível para salvar a Judite., né? Então, eu achava que de novo ela ia conseguir; eu não achava que minha filha ia morrer." (F12)

Por outro lado, os conflitos vivenciados com a equipe, como comunicações divergentes e falta ou omissão de informações sobre a doença e o tratamento, contribuíram para que a mãe ficasse impossibilitada de aceitar o anúncio da nova condição de estar em cuidados paliativos da criança. Ela se percebe não podendo acreditar no que the foi dito pela equipe da oncologia.

"Chegando lá" (primeiro tratamento), "aí passamos com a doutora, aí eu falei: $\mathcal{N}$ ossa doutora, não temos como operar! Aí ela disse assim: 'A senhora quer que eu tire a cintura dela ou o quadril dela?' A doutora disse isso para mim! Foi uma coisa que me marcou muito, que me doeu muito na época! Eu estava tão assim..., sabe?, que eu falei: Não, minha filha vai sarar doutora', eu falei para ela. Aí passou oito meses e sumiu o tumor, desapareceu! Foi seis sessões de químio e 10 sessões de rádio e sumiu o tumor. Ai eu cheguei para a doutora para falar para ela e ela falou assim: 'Eu não sei, mãe, como esse tumor sumiu, nós nos enganamos'. Mas o médico não tem o direito de chegar e falar isso para você de cara: você quer que eu tire a cintura ou o quadril dela, sabe? $\mathcal{E}$ depois vem de novo me falar que não tem mais nada para fazer, como que eu ia acreditar nela? Como? Não dava para acreditar!" (F11)

Ao receber a notícia de que o filho está em cuidados paliativos, a família sente um descaso em relação ao tratamento da criança, entende que ela está sendo desconsiderada pela equipe para seguir na luta contra a doença, o que ela não pode aceitar. Diante disso, perde a confiança, sente-se desapontada com a equipe de saúde, decepcionada com a postura da equipe de não confiarem mais no tratamento. Assim, não consegue mais acreditar no que é dito, bem como nas condutas tomadas em relação à criança. 
"Ele fechou o diagnóstico dele, que o menino não tinha mais nada que pudesse ser feito, tudo que tinha que ser feito já tinha sido feito. Ainda tinha um protocolo para fazer que ele chamou de GDPP, mas não sei o que que é esse GDPP. Aí ele ia fazer um resgate para depois (...), mas que era paliativo" (voz enfática), "que ele não acreditava que ia ter resultado. (...) eu tinha uma relação de confiança profunda assim com o médico, então eu entreguei meu filho assim praticamente nas mãos dele, né? (...) aí quando ele me deu... Eu sabia... Aí quando ele falou para mim assim, ele foi e deu o diagnóstico para mim assim, que o menino..., que já não tinha mais o que fazer. Nossa! (...) são coisas assim que foram somatizando, né? $\mathcal{E}$ foram desgastando a minha relação de confiança com ele, né? Aí, depois que eu conversei com a outra doutora, que ela me disse que ele não podia ter usado aquele protocolo no meu filho, eu falei assim para ele: O senhor me desculpa, mas está totalmente comprometida minha relação de confiança com o senhor!" (F7)

Para a mãe, existe uma dissonância em relação à equipe médica relacionada à perda, vista como incoerente, infundada e mantém a crença de que a equipe está enganada e que ainda possa haver uma solução para vencer a doença. Essa desarmonia entre a expectativa de vida da criança para a equipe e para a mãe faz com que ela questione a equipe de saúde sobre novas possibilidades de tratamento.

"Então, por isso que meu chão abriu! A pessoa assim em quem eu confiei assim a Judite, que eu acreditava piamente. Eu não achava ela com o poder de curar minha filha, mas eu ACREDITAVA nela, em tudo que ela falava eu acreditava. A partir do momento que a doutora falou aquilo para mim" (que a cura não era mais possivel), "eu deixei de acreditar $\mathcal{N} E \mathcal{L} \mathcal{A}$, porque a gente faz o que a gente quer com a nossa cabeça, né? (...) e eu falava para ela: Nõa, doutora, a senhora tem que encontrar uma saída, tem que ter alguma coisa para fazer sim." (F12)

Ao ficar descrente com a capacidade de cura dos profissionais após ter ouvido que nada mais poderia ser feito para promover a cura do filho, a família volta-se para o lado religioso/espiritual, acreditando que se naquele momento os médicos não conseguem mais dar conta da situação, somente Deus ou uma força suprema poderia salvar o filho. Destarte, entrega-o ao poder de cura de Deus e busca recursos em novas religiões, igrejas e mantém a esperança de que sua fé salvará a criança.

"E agora? Se em quem eu confiava, quem eu depositei todas as minhas confianças aqui na Terra... E agora, né? Aí vem o lado espiritual, né? Aí você vai buscar força, né? Você não pode 
desanimar, você tem que buscar força em alguma coisa, em alguém, né? É assim, né? É Deus (...), porque se já não depende mais dos médicos, se os médicos desistiram, só Deus! Aí você fica naquela apreensão, porque é só Deus que pode, se Ele quiser..., se for o melhor, não é se Ele quiser, porque Ele não faz nada se for ruim para a gente, né? Se for o melhor, só Ele pode. Então é isso. E você começa nessa luta interior, né?, de não querer fraquejar... Eu, pelo menos, de não desistir e de pedir para Deus, pedir para Deus, pedir para Deus e achar que, a qualquer momento, vai acontecer um milagre e não desanimar." (F12)

“Essa parte é ruim, porque enquanto você está com fé... As pessoas... Eles são médicos, eles lidam com a realidade, né? Você está entendendo? Eles lidam com o que eles têm! Eu não, eu sou mãe, se eu quiser apelar para a pedra, eu apelo e se eu quiser ter fé naquilo, eu tenho! Eu não quero que ninguém discorde de mim." (F10)

\section{Precisando manter a criança viva}

A realidade vivida pelos pais até o momento em que eles foram informados que a condição clínica da criança exclui qualquer possibilidade de cura foi a de que a criança tinha um papel ativo na família e, apesar de uma luta difícil inerente ao tratamento, ela ainda teria uma vida longa. Esta nova realidade gerada pela informação de que curar não é possível e que a doença progride a cada dia leva a uma redefinição da situação por parte dos pais. Redefinir envolve uma mudança na visão dos pais em relação à criança, do que costumava ser e o que é agora. Esta mudança é difícil, especialmente quando os membros da família apresentam pouca mutualidade ou discordam da condição da criança. Para estas famílias, redefinir a condição do filho em um contexto de sofrimento não é uma tarefa possível neste momento; significa ter de transformar a realidade vivida até então, aceitar serem os pais de uma criança que pode morrer ou que está morrendo, e isto eles ainda não podem aceitar. Diante deste fato, os pais estabelecem a manutenção da vida da criança como prioridade para as suas vidas.

"E a gente não desanima, né? Dá muita força um para o outro e tal. $E$ a gente vai vivendo, né? Então, para mim, sempre a gente está lutando pela vida dele" (do filho). "(...) agora, assim, a gente sempre tem esperança, assim, de ele, pelo menos, ir vivendo com menos sofrimento. 
Isso é o que a gente espera mesmo, mudar da forma que é possível. Mas a gente sempre quer a melhora para ele, né? Sempre está junto dele... sempre lutando (...)" (F6, pai)

As definições a respeito da identidade da criança, bem como suas crenças sobre a condição dela direcionam os comportamentos de como cuidar da criança. Reconhecendo o filho como um guerreiro representa o esforço da família em manter o foco nos resultados positivos apresentados pela criança mesmo após sua inclusão no grupo de cuidados paliativos. Assim, não pode aceitar desistir do tratamento e começa sua nova luta porque precisa manter sua criança viva. Frente a isso, a família não pode concordar com a equipe renunciando ao tratamento curativo, pois isto significa desistir do próprio filho e dos seus sonhos para o futuro e é o que ela não pode permitir. Assim, impõe-se como guardiã da criança na tentativa de buscar uma nova oportunidade para o filho.

"OCha, eu não sei quantos dias de vida eu tenho com meu filho. Eu descobri agora e está assim... É violenta a doença, eu não sei se eu tenho um dia, uma semana ou um mês, eu não sei quantos dias que eu tenho com ele. Eu só preciso fazer alguma coisa por ele, proteger ele." (F7)

Precisando manter a criança viva, a família está aberta e disposta a enfrentar os desafios para alcançar a cura ou evitar a progressão da doença. Quer provar que a equipe de saúde está errada e que o filho permanecerá com ela.

"Eu sempre lutei pela vida da minha filha, porque eu acho que tudo que eles falaram, tipo: 'Ai, vai vegetar, não vai enxergar, não vai mexer a mão, não vai fazer nada...", ela fazia, entendeu? Fazia porque eu ficava em cima dela mesmo, porque eu queria ensinar ela fazer, porque eu ensinei ela a dar tchau, mandar beijo, ensinei ela a chamar, assistir televisão, tudo que eles falaram que ela não ia fazer. Então, dentro de tudo isso, eu brigava. Ela viveu comigo três anos, já pensou se eu tivesse desistido logo de cara?" (F14)

Após a família ser posta diante da experiência de receber da equipe de saúde a notícia de que seu filho encontra-se em cuidados paliativos, percebe-se TENDO A VIDA ESTILHAÇADA e, a partir desse momento, os familiares precisam agir para lutar pela vida do filho; para isso, têm de definir a realidade em relação à gravidade do estado de saúde da criança. $A$ 
definição da realidade do que possa estar acontecendo com o filho é a fase da interação com o objeto - cuidados paliativos - e com eles mesmos. Cada membro familiar faz a sua definição a partir de como vivem a experiência e das interações com as pessoas, o que, por sua vez, leva à ação e às suas consequências.

\section{MANEJANDO A NOVA CONDIÇÃO}

Frente ao impacto causado pela notícia de ter um filho em cuidados paliativos, a família é submetida a todo um processo de desequilíbrio e recomposição das forças que a mantêm. A intensidade e a duração do desequilíbrio dependerão, fundamentalmente, das demandas atendidas com as informações adquiridas durante a experiência e o suporte social, bem como dos recursos que a família dispõe, como a capacidade de se comunicar e tomar decisões sem grandes conflitos. Sabe que terá de ser determinada e buscar recursos dentro e fora do âmbito familiar, nos quais possa se apoiar para continuar lutando pela vida do filho.

Por conseguinte, ela tem um papel ativo no decorrer da experiência, age com o objetivo de manejar a doença e, sempre que possível, manter o filho em casa, preservando a sua qualidade de vida e da família, a fim de evitar o sofrimento físico e emocional, tanto quanto possível. Assim, MANEJANDO A NOVA CONDIÇÃo representa as ações da família no sentido de manter um equilíbrio entre atender as demandas da doença e a preservação da sua vida cotidiana em virtude da situação ameaçadora e instável de ter uma criança/adolescente em cuidados paliativos.

Estas ações representam as estratégias e mudanças que the permitem reconstruir e redefinir sua vida e garantir que o cuidado possa ser levado adiante, independente de seu desfecho. MANEJANDO A NOVA CONDIÇÃO inclui obter informação sobre o cuidado médico e as crises advindas com o aumento da sintomatologia e progressão da doença, a comunicação, ou falta desta, entre os demais membros familiares sobre o prognóstico da criança/adolescente e a obtenção de recursos que possam tentar ajudá-los a facilitar a tarefa do cuidar e o engajamento da família em seguir lutando pela vida da criança/adolescente. Ao manejar a nova 
condição, a filosofia dos pais passa por um processo de negociação entre a dor ou sofrimento imposto pela situação da criança/adolescente e a busca por uma qualidade de vida melhor, uma forma mais aceitável de continuar levando a vida em família.

A categoria é representada pelas subcategorias: "Precisando de suporte", "Mantendo a criança/adolescente em casa", "Vivenciando perdas" e "Engajando-se no cuidado".

\section{Precisando de suporte}

"Precisando de suporte" representa a família reconhecendo que, para manter o cuidado que deseja oferecer para o filho, precisa de adeptos, tanto familiares, quanto de amigos, membros da equipe de saúde e mesmo de outras famílias que estejam vivenciando situações semelhantes à sua por também possuírem um filho em cuidados paliativos, que a estimulem a continuar fortalecida e com esperança para seguir cuidando e lutando pela vida de sua criança/adolescente. Suas crenças religiosas e espirituais também constituem recursos importantes para o enfrentamento da situação.

O suporte é representado por uma corrente que se forma ao redor da família e que a ajuda a ter esperança de continuar lutando pela vida do filho ou pela melhoria de sua qualidade de vida. São pessoas quase que persuadindo a fazê-la sentir-se emponderada e esperançosa, que permanecem por perto, ouvindo, compartilhando o sofrimento e lhe proporcionando, até onde podem, alívio. Estas pessoas chegam com ações, pensamentos e a intenção de suavizar seu sofrimento e compartilhar sua dor. A família sempre encontra pessoas que a ajudam a superar as dificuldades. Assim, ao identificar seus principais recursos, consegue começar implementar suas estratégias para o enfrentamento de ter de conviver com o filho em cuidados paliativos, sempre procurando manter uma nova normalidade para sua nova vida.

A doença é um evento familiar. Portanto, as relações estabelecidas entre os seus membros no engajamento de cuidar e continuar lutando pela criança/adolescente, mesmo com conhecimento de um prognóstico sombrio, é um impulso para que encontre forças para continuar vivendo, apesar de toda 
sua angústia e pesar com as sucessivas perdas. Esse engajamento inclui desde tarefas de cuidados cotidianos de higiene, medicação, como suporte emocional. Poder contar com o apoio familiar a auxilia a seguir em frente, com o firme propósito de conseguir a recuperação e cura do filho. A mãe reconhece o empenho de outros membros familiares em auxiliar no cuidado da criança/adolescente e em serem seus parceiros no decurso da doença.

"Na minha casa, cada um participa um pouquinho do nosso dia a dia. Tem o pai que ajuda, as duas irmãs. Este meu sobrinho está sendo um anjo para mim, às vezes ele fala: 'Está cansada, fica no sofá que eu vou ejetando a janta dele.' Que de cinco em cinco minutos, a gente ejeta umas seringas, né? Então, todo mundo... até os namorados das meninas compartifham disso aí, não é nenhum problema para nós, sabe? (...) a gente conversa sobre o que está sentindo (...), isto ajuda muito, alivia a gente de um tanto..." (F6, mãe)

“(...) as minhas irmãs, elas falaram assim: 'Nós somos sua família, você não vai ficar sozinha, nós não vamos deixar você ficar sozinha e não deixaram. Então, isso é muito bom para gente, assim..., a família é... Como eu digo: É a estrutura que eu acho que às vezes... Tem muita gente que, às vezes, não tem esse apoio e faz falta, faz a diferença! A gente também esquece um pouco o que pode acontecer para frente, sabe?" (F2)

A atenção da família está voltada para manter a integridade da unidade familiar e buscar energias para cuidar do filho doente da melhor forma possível. Ao tentar superar o sofrimento para se manter forte, a família vai oscilando, um tentando ajudar o outro. É como se soubesse que não dá para todos estarem juntos "para baixo"; isto não é bom para ninguém tampouco para a criança/adolescente doente.

“(...) minha esposa, né? É uma pessoa assim (...) de muita garra, de muita coragem, fibra... E a gente não desanima, né? Dá muita força um para o outro. E a gente vai vivendo, né? Então, para mim, sempre a gente está lutando." (F6, pai)

Em algumas famílias, mesmo que outros membros seus tenham a disposição de participar e auxiliar nos cuidados para com a criança/adolescente, a mãe percebe que, para muitos, a missão de acompanhar e auxiliar nos cuidados da criança/adolescente em cuidados paliativos torna-se dolorosa, uma vez que estes não conseguem lidar com o 
sofrimento da criança/adolescente imposto pela doença e por sua progressão, dificultando que a responsabilidade do cuidado seja compartilhada.

Ao perceber esta realidade, geralmente a mãe toma para si a preocupação de cuidar também do restante da família frente à situação de cuidados paliativos da criança/adolescente. Eles fazem com que ela reconheça e imagine as limitações emocionais dos membros de sua família que acompanham o tratamento e a história de doença do filho em relação ao que cada um pode suportar ou deve saber em termos de informação sobre o seu real estado de saúde. Por vezes, prefere omitir informações sobre o real estado clínico do filho, com o objetivo de procurar resguardar a unidade familiar de mais sofrimento.

"A minha filha... Eu falo muito pouco de Rafael para minha família, muito pouco. Eu só falo que o quadro é grave, que ele sente muita dor, né? (...) se acontecer... Olha, Rafaek não aguentou! O Rafael," (pausa) "ele partiu! Ele já não..., já não vai mais, né? É mais nesse sentido. Porque é muito ruim você deixar as pessoas sofrendo por antecipação, né? Eu não acho justo! Basta só eu, né? Já está de bom tamanho, né? E a responsabilidade, depois é melhor, é mais sauđável para eles também, né? Tenho que carregar sozinha por enquanto! Tem que ser assim, né? Assim, acho que é mais saudável para os outros também!" (F7)

“... minha mãe era interessada em tentar ajudar em algumas coisas, só que ela não tinha coragem também. Mas, conversar sobre os problemas da Janaina com ela... A gente conversava, sim, mas tinha coisas que eu preferia não falar, ela tinha muito medo da Janaina. morrer! Então, aconteciam coisas no hospital com a Janaina. que eu nem contava, guardava aquilo só para mim! (...) no geral, a gente conversava a respeito dos problemas da Janaina. Eu acho até que era a única pessoa que se interessava em saber o que estava acontecendo. Por quê? Porque ela..., ela ia visitar um dia sim, um dia não e quando ela ficava em casa, ela ficava 24 horas junto comigo." (F14)

Porém, a experiência, para algumas mães, pode ocorrer sem que ela encontre recursos ou suporte na família durante a trajetória dos cuidados paliativos, sentindo-se desamparada em seu sofrimento.

“(...) desde o começo," (da doença) "eu me vi sempre sozinha para cuidar do Vinicius (...) quando se tem uma família mais unida, que é muito grande... Eu sempre fiz tudo assim do Vinicius, a maioria das coisas..., tudo eu, né? Então, eu falo sempre, bato na mesma tecla sempre, não é assim me lamentando, é porque a realidade é essa, desde a doença do meu filho que eu sempre me vi sozinha, né?" (F8) 
A mãe se vê sozinha e sofre ao reconhecer que, para o parceiro, a doença do filho é uma decepção que o coloca frente à sua incapacidade de suportar e lidar com a situação, dificultando que se aproxime e participe de forma proativa desta nova realidade. A mãe reconhece a dificuldade do parceiro em lidar com a situação, mas reforça sua necessidade de poder compartilhar a experiência, sentir-se apoiada.

"Porque eu acho assim... que, independente do que seu filho tem, ele não tem culpa de ter nascido com aquilo e você que tem que assumir, independente de qualquer coisa. E ele não, ele queria uma boneca 6onita, para mostrar para os amigos dele, levar na casa do pai dele, mostrar para irmão dele (...) e não foi isso que ele achou, entendeu? Porque ele se deparou com um monte de problemas, que ele não tinha estrutura para nenhum desses problemas. Não tem estrutura para ter um filho doente! Porque ele, ao invés de tentar resolver o problema, ele chora e não me ajuda, porque eu não preciso de ninguém para chorar na minha frente, como ele fazia. Eu preciso de alguém para me apoiar, para me ajudar a decidir alguma coisa, e ele nunca fez." (F14)

Em algumas situações, sente a falta de interesse do marido em relação ao tratamento e acompanhamento médico do filho. O desinteresse demonstrado pelo pai em relação à situação da família durante todo 0 decurso da doença pode provocar desentendimentos e distanciamento entre o casal, uma vez que a mãe interpreta a ausência do marido, sobretudo na fase de cuidados paliativos, como um desinteresse aos assuntos familiares e sobre a vida do filho; sente-se traída por não se conformar com o seu distanciamento. Sua expectativa para o papel de pai é que existisse uma aproximação da criança/adolescente e da família frente à situação de doença e risco de vida. Sente-se desapontada por não poder contar com o apoio do marido para enfrentar a progressão da doença, perde a confiança nele, não admite tamanha desconsideração com o filho, não podendo, pois, dividir com ele as decisões referentes ao tratamento a partir deste momento.

“(...) a maior dificuldade é ser sozinha. Eu não sou separada, mas é quase isso. E eu sou sozinha! Você vê que não vem outra pessoa aqui, quando vem, vem a prima. (...) sinceramente falando, eu não converso com o meu marido" (sobre a doença da filha)" porque ele não procura, $e$ eu não tenho paciência de ficar falando." (F3) 
“(...) ele nunca chegou vim conhecer o... Nossa! Eu fico pensando, uma vez só durante todos os anos, eu acho que foram quatro anos de Clínicas! SNossa! Eu nunca pensei nem por um minuto em deixar minha filha vir com alguém (...), como pode uma pessoa, um pai não querer vim conhecer o médico, conhecer o hospital onde a filha trata, gente? Participar, não saber o nome de um medicamento... Eu não poder confiar..., deixar ela um minuto ali com ele (...). Eu penso que ele é uma pessoa doente, é uma pessoa egoísta, completamente centrada nele." (F12)

Mesmo assim, estas mães reconhecem que precisam continuar engajadas na sua batalha pelo filho e se mantêm ao lado da criança/adolescente assumindo para si a responsabilidade do cuidado e do acompanhamento médico do filho; mas sentem, e muito, o peso de assumir tamanhas responsabilidades e se imaginar no futuro diante das decisões que possam vir a ter de tomar com relação à vida do filho, ou mesmo refletir sobre as escolhas já realizadas e suas consequências para futuro do filho, o que torna a experiência solitária e angustiante. Ela quer e precisa de apoio, mas desconhece a forma de obtê-lo.

“(..) porque era assim, ele" (pai da criança) "não aceitava não. SNem ele nem a família dele. Então, todas as coisas que iam ser feitas, ele criticava. Eles não aceitavam ela (...). Então, eu nem perguntava que conduta eu tinha que tomar, o que tinha que fazer, porque a decisão eu sempre tomava sozinha. E se acontecesse alguma coisa, ele sempre jogava nas minhas costas. Então, foi muito difícil para mim! Eu já nem perguntava mais a opinião dele, eu já ia lá e decidia. Eu tinha de decidir sozinha tudo, mas tinha medo de errar, de não dar certo! Eu tive que decidir a tráqueo, a gastro, sabe? Graças a Deus, deu tudo certo e eu pude levar ela para casa comigo; mas e se desse errado? Como que ia fica a minha cabeça? (...) Eu preciso de alguém para me apoiar, para me ajudar a decidir alguma coisa, e ele nunca fez." (F14)

Ao mesmo tempo em que se desdobra com relação ao cuidado para com o filho e o restante da família, ela também sente necessidade de receber atenção, sentir-se cuidada e ter seu sofrimento reconhecido com a experiência da possibilidade de perdê-lo. Nessa experiência com o filho em cuidados paliativos, depara-se com sua necessidade de recarregar as energias para poder prosseguir sua batalha.

"Eu acho que eu tenho que cuidar do marido da filha dele." (Filho doente) "Eu queria alguém que cuidasse de mim às vezes, mas na minha casa é o contrário, todos para resolver alguma coisa têm que passar por mim. Eu também queria um colo, sabe? (F6, mãe) 
“(...) eu sofro com tudo isso, mas não posso mostrar! Então, nessas horas, faz falta um agrado. Eu tenho meu canteiro de plantas, quando a Elaine não está bem, que eu vejo que o negócio está desandando, me dá aquele medo de perder ela, né? Não tem jeito, isso vem mesmo! Eu vou lá, aí pareço uma louca, né? Mas eu vou lá, converso, choro, reclamo da vida. (...) significa para mim minha terapia, quando uma delas tem uma florzinha, eu fico maravilhada!" (F3)

Os familiares, com medo, angustiados, trocam experiências com outros familiares que também estão com os filhos em cuidados paliativos. As famílias compartilham sentimentos de suas experiências em conversas informais de corredor, enquanto aguardam atendimento ambulatorial ou nas enfermarias. Elas procuram conversar com outros familiares de outras famílias que estejam vivendo a mesma experiência com o firme propósito de tentarem aliviar sua dor e perceberem que não estão sozinhas nesse mundo rodeado por perdas. Conscientizam-se que podem compartilhar sentimentos e tarefas com outras famílias que vivem a mesma realidade. Ela busca suporte para superar esta experiência e manter sua esperança para seguir lutando para a recuperação da criança/adolescente.

"Aqui tem muita criança com doença que não para curar sabe, então quando a gente está esperando ser atendido, vai conversando, conhecendo gente, a gente acaba se abrindo com pessoas que a gente nem conhece (...) mas é 6om, a gente vê que não está sozinha, sabe?” (F5)

“(..) aqui vemos outras crianças passando por coisas ruins e tendo sua saúde debilita e indo (...). A gente quer ajudar (...), estamos com o mesmo problema, a gente acaba tendo os mesmos medos, né? (...) conversar com eles ajuda a gente, dá força para continuar em frente." (F15)

O impacto causado pela notícia de ter um filho em cuidados paliativos permeia a experiência da família continuamente, coloca-a frente a um mundo desconhecido permeado pelo medo contínuo de que a jornada traga dor e sofrimento ao filho e que estes não possam ser controlados. Assim sendo, encontrar um profissional de confiança dentro da equipe, em quem encontra continência para seus anseios e questionamentos possibilita seu enfrentamento ao impacto da notícia, uma vez que lhe proporciona segurança para seguir na experiência, acreditando que o filho não será abandonado e continuará recebendo atendimento e conforto. Poder confiar na equipe e se sentir segura de que tudo o que está ao alcance da medicina 
está sendo realizado auxilia a família em sua busca para significar as perdas que vêm enfrentando.

"Então, na hora que ela falou para mim, eu acreditei e eu vi, porque ela gostava muito da Judite. Nossa! A doutora tinha a maior admiração pela Judite mesmo, e eu sei que ela também estava sofrendo e eu sei que se ela desistiu é porque não tinha mais o que podia ser feito, entendeu? Mas ela me tranquilizou, ela falou assim: 'Fica tranquila! É (...), ela não vai sofrer, eu vou procurar dar o máximo de conforto para ela, vou transferir ela para um quarto, vamos dar medicação e ela não vai sofrer'." (F12)

A família reconhece o papel fundamental que a equipe de saúde tem em sua trajetória com o filho em cuidados paliativos e o quanto precisa de seu suporte para que consigam capacitar-se e estar segura para cuidar do filho em casa. Entretanto, ao se deparar com a nova realidade, dando conta das inúmeras perdas que ele e, consequentemente, toda a família vem sofrendo, reconhece, na equipe de cuidados paliativos, um suporte adicional, porque lhe permite a tranquilidade de poder ver a criança/adolescente bem, com os sintomas controlados e, com isso, a possibilidade de estar com ela em casa, mas também o suporte emocional. Nessa nova relação, encontra um espaço onde pode cuidar dela, mas é um momento onde também se sente cuidada e amparada em suas angústias e em seu pesar.

"Igual [...] eu peguei um apoio neles que eu não sei qual [...] Aí você entra e a doutora fala: 'Ah, você hoje está mais animadinha, parece que eu melhorei não só o paciente como melhorei a mãe.' Mas melhorou mesmo, eu falo para elas, porque eu venho aqui, vocês tratam do meu menino e ainda fica me escutando falar, falar... Nossa! É muito 6om isso. E o mais importante, eles falam tudo do filho da gente, não escondem as coisas, sabe? Só que eles ajudam a gente entender o que está acontecendo, sabe?, e como tem que fazer para ajudar ele e ajudar a gente também a ir levando a vida da gente, porque não vou te dizer que é fácil porque não é!" (F6, mãe)

Em alguns casos, a interação com a equipe de saúde pode estar comprometida e a falta de confiança pode fazer com que a família procure por um novo serviço. Buscar uma nova opinião sobre a condição do filho significa a possibilidade de encontrar uma nova oportunidade para 0 prognóstico da criança/adolescente, a sensação de dever cumprido e a oportunidade de manter sua esperança em conseguir manter sua vida. 
“(...) eu não tinha confiança no médico, ele não soltava o menino e eu não sabia o que eu fazia. O que que eu ia fazer? Porque para mim, eu queria que eles me dessem a oportunidade de eu sair de lá e que viesse para cá, para São Paulo, tentar alguma coisa aqui! Mesmo que fosse para eu voltar frustrada, mas eu gostaria de dar essa oportunidade para ele! Expliquei tudo para ela, trouxe todos os exames, tudo, tudo, tudo, tudo entreguei e falei: Pronto, meu coração está aliviado, porque nós estamos em outro centro, uma nova oportunidade! Ai eu falei: Meu filho, está aí, oh, o que a mamãe podia fazer está aqui. Aqui que fez tudo que tinha que ser feito e é o mesmo prognóstico de lá, que não tem mais nada para fazer, que não tem nada para fazer mais! $\mathcal{E}$ é assim que nós chegamos até agora!" (F7)

As questões religiosa e espiritual aparecem durante toda a caminhada da doença da criança/adolescente no curso de sua doença, permanecendo presente no momento em que a família é comunicada que não há nada mais a ser feito do ponto de vista curativo pela criança/adolescente e que a doença progride.

Diante de tantas adversidades impostas por toda a trajetória da doença e frente à possibilidade cada vez mais real da morte do filho, os familiares deixam explícitas a importância das crenças religiosas e a sua fé em uma força maior, que pode ser sua única chance de alcançar a cura da criança/adolescente. A família reconhece a religiosidade e espiritualidade como um recurso de suporte nas situações de doença e morte e como uma forma de ajudá-los a enfrentar estas situações. Por vezes, a fé reforça a esperança de uma cura milagrosa e no poder de uma força maior que pode conseguir salvar o filho, trazendo mais tranquilidade para enfrentar as adversidades.

"A gente tem que seguir em frente, não podemos parar. Se Deus deu ele para a gente, nós vamos até o final. A gente acaba pondo na mão de Deus (...). Aí Deus vai fazer isso, Deus vai fazer aquilo... A gente nunca deixa a tristeza nos abater, porque (...), acima de tudo, está Deus!" (F6, pai)

“(...) eu não aguento, eu rezo todo santo dia, só se for um milagre de Jesus. (F1, avô)

Também, algumas vezes, em suas crenças religiosas e espirituais é que encontram um sentido para a perda que estão vivenciando. O que está ocorrendo em sua vida e aceitar a situação de cuidados paliativos do filho 
como um desígnio de Deus é resignar-se a uma situação, mesmo que seja contra ela, porque isto é da vontade de uma força superior contra a qual não se tem como ir contra, é inevitável.

“(...) tudo ia ser segundo a vontade de Deus, não era a minha vontade nem a vontade dele. Mas aquilo que Deus reservava para nós, que nós tínhamos que ter aceitação para poder enfrentar tudo isso junto!" (F7)

\section{Mantendo a crianca/adolescente em casa}

A família da criança/adolescente em cuidados paliativos reconhece que a vida agora exige mudanças e adaptações no contexto de todo o sistema, buscando manter uma filosofia de cuidados que mantenha a sua vida o mais próximo ao que era antes da chegada da doença. Para viver assim, a partir de agora, precisa redefinir a realidade de normalidade que experiência, tomando consciência que a vida não será a mesma e a nova normalidade do contexto familiar é adquirida quando percebe que tem algum controle sobre os cuidados e pode incorporá-los à sua rotina.

Assim, "Mantendo a criança/adolescente em casa" a meta é lutar para manter um equilíbrio entre o cotidiano da vida familiar e a melhor qualidade de vida dela e da criança/adolescente. Permanecer em casa com o filho é o que Ihe dá tranquilidade para perceber sua condição estabilizada. Neste momento, afasta a possibilidade da progressão da doença e morte do filho do contexto familiar, que reforça sua esperança em poder permanecer junto a ele por muito tempo ainda.

Contudo, esta nem sempre é uma opção da família e ela se dá conta disso no decorrer de sua trajetória. O poder permanecer ou voltar com a criança/adolescente para casa envolve fatores que independem exclusivamente de sua vontade, como a estabilidade do quadro clínico da mesma, conseguir um adequado controle de sintomas e, em alguns casos, possuir uma estrutura que possibilite a manutenção, aprendizagem e o uso de equipamentos no caso de crianças/adolescentes dependentes de tecnologia. 
“(...) de chegar uma época aqui dos médicos falarem assim: 'Mãe, o Vinícius só vai para casa se tiver como arrumar o oxigênio para ele, sem isso tem que ficar aqui ou ir para uma casa de apoio." (F8)

"Eu não consegui o bipap lá; então, eu movi um processo porque eu achava injusto ela não poder ir para casa, sendo que ela tinha condições de ir. Aí, começou outra guerra, porque eu tive de aprender a mexer com todos esses trecos de bipap e essas coisas. Nãa foi fáci!! Eu... Mas eu aprendi e eu levei ela para casa com bipap (...), mas para ela conseguir ficar bem no bipap e poder ir para casa foram quase dois anos vivendo dentro de um hospital." (F14)

Frente aos inúmeros desafios para conseguir manter o filho no ambiente doméstico, a família não desanima e se mostra proativa na obtenção de recursos materiais, da capacitação de habilidades pessoais que Ihe permita cuidar do filho em casa. O manejo da doença em cuidados paliativos no ambiente doméstico representa os esforços direcionados por ela ao cuidado com a doença e adaptação da vida familiar às demandas relacionadas à doença, incluindo metas e estratégias relacionadas ao cuidado do filho que permita o desenvolvimento de uma rotina de cuidado da criança e a incorporação desta ao cotidiano da vida familiar.

"Então, ela ficava em casa com o bipap, oxímetro... Aí tinha uns oxímetros acoplados no 6ipap... Ficava com 6omba de infusão para receber dieta, porque eu não gostava muito desse negócio de ficar empurrando na seringa, eu achava que distendia, porque vai um pouco mais rápido. Então, tinha tudo isso em casa e eu tive de me virar para aprender e dar conta de mexer com tudo isso. O quarto era montado só para ela mesmo, tinha um sofá-cama para mim, porque eu dormia junto com ela, como se fosse no hospital, a diferença é que era em casa, mas era com bipap o tempo todo." (F14)

Para a família, conseguir manter a criança/adolescente no domicílio representa uma oportunidade de tentar manter seu controle sobre o ambiente e sobre seu filho, o que considera ser perdido quando estão no ambiente hospitalar. Poder estar em casa com o filho permite à mãe preservar e/ou resgatar a sua relação com a criança.

"Quando eu consegui levar ela para casa, eu me realizei, assim, enquanto mãe dela. Eu queria levar ela para casa por mim e por ela, porque eu sabia que em casa a gente ia viver coisas 
que a gente não conseguia viver dentro do hospital. Então, eu me realizei enquanto mãe dela. (...) ser eu e ela, eu por ela e, talvez, ela por mim. Porque ela me completava, entende? E ... você sabe, dentro do hospital está sempre dentro de um quarto, apesar que sempre colocavam ela sozinha, no quarto, por causa de tudo, mas toda hora tinha gente lá, toda hora tinha alguém. Independente de ser de dia, de noite, de madrugada, toda hora tinha gente no meio. A gente viveu muito isso em casa, de cumplicidade, dela olhar para mim e eu saber o que ela queria." (F14)

Para a mãe, manejar a condição da criança/adolescente em casa permite que ela conte com o apoio dos outros componentes da família, podendo também preservar os vínculos entre eles. A apreciação dos membros familiares das contribuições uns dos outros traz uma sensação de apoio e união e permite que eles organizem tarefas domésticas e os cuidados da criança/adolescente de forma flexível. Assim, a família é capaz de integrar funções e responsabilidades, conseguindo, por vezes, oferecer ao cuidador principal, que geralmente é a mãe, um tempo de repouso e oportunidades para satisfazer as necessidades dos irmãos.

"Na minha casa, cada um participa um pouquinho do dia a dia nosso (...). Este meu sobrinho está sendo um anjo para mim; às vezes ele fala: 'Está cansada, fica no sofá que eu vou ejetando a janta dele.' Que de 5 em 5 minutos a gente ejeta umas seringas! Todo mundo entra na brincadeira ali, todo mundo cuida dele e a gente pode estar junto (...), tenta esquecer um pouco do hospital, cuida das filhas um pouquinho (...). Você tem que viver uma vida para ele, mas isto não impede de fazer as outras coisas. Você consegue Limpar a casa, cuidar dele, aspirar ele, dar inalação (...), tem que seguir em frente." (F6, mãe)

Poder estar em casa com o filho representa momentos de harmonia e tranquilidade. São períodos decorrentes da fase onde se consegue 0 controle da progressão da doença e dos sintomas. São momentos permeados de alegria por se poder realizar atividades cotidianas da família e ter a presença da criança/adolescente doente, esquecendo-se, por alguns instantes, da situação que os ameaça com a possibilidade de morte do filho. Perceber o bem-estar da criança/adolescente possibilita que a sua família mantenha sua crença de que ela pode se recuperar e isto é fundamental para que continuem lutando pela vida do filho.

"Eu aproveito no dia que ela está bem para gente poder passear em outro canto. Nesse dia aqui, ela está tão bem!" (Mostra a foto das filhas) "Foi ao shopping comigo e com minha outra filha no 
shopping, se acabaram de tomar sorvete, batemos perna o dia inteiro. Então, isso para mim foi assim... lindo! Sossa! Parece besteira, né?, uma coisa tão 6o6a ir no shopping, mas para mim esse dia foi muito importante! Ver ela conseguindo fazer essas coisinhas, sabe? Fazia tempo que a gente não conseguia dar umas voltas porque ela não estava nem andando direito e aquelas dores, tudo... Quando ela está bem, acaba meu estresse. Mas quando ela não está bem, que ela está sentindo muita dor e eu não consigo acalmar, fico doida, não consigo fazer nada, só fico perto dela, choro junto!" (F3)

A família luta pela qualidade de vida da criança/adolescente como se estivesse se prevenindo de sua morte. O bem-estar do filho é um indicativo da qualidade de vida familiar. Eles aproveitam o contato contínuo com a criança/adolescente para lhe reassegurar o amor incondicional que os pais sentem por ela. Acreditam que, assim, estão promovendo uma qualidade de vida melhor para o filho e a família.

"Eu sempre vivi para ela e com ela de uma forma muito intensa! Sempre vivo o hoje como se fosse o último, porque eu sempre falei assim: Ela só vai morrer quando tiver que morrer, porque, por falta de cuidado ou por negligência de alguém, não vai ser, porque eu vou atrás." (F9)

"Olhar a cara do meu filho assim... Se ele está bem, eu estou bem. Não adianta, a minha vida está bem se a dele estiver bem." (F6,pai)

Contudo, a família reconhece que, ao direcionar seus esforços para manter a criança/adolescente em cuidados paliativos em casa, deve estar preparada para a responsabilidade a que está exposta, dado que, em algumas situações, tem de aprender manejar o cuidado de uma criança tecnologicamente dependente. Além disso, deve aprender a lidar com gastrostomia, traqueostomia e medicações. Portanto, ser responsável pelo cuidado do filho em casa representa a família sentir-se capacitada para detectar alterações que possam desdobrar em complicação do quadro clínico da criança/adolescente e apta para controlar os sintomas advindos com a progressão da doença. Esta experiência a faz sentir-se insegura e vulnerável, necessitando, por isso, pensar em novas estratégias para poderem superar seus medos e inseguranças de manejar o cuidado com o filho.

Seu grande medo é que acorra uma intercorrência com a criança/adolescente e que ela não perceba ou não consiga socorrê-lo a tempo, provocando ou acelerando sua morte. A mãe vê a ocasião como uma 
oportunidade para reconhecer sua responsabilidade sobre esse cuidar e desenvolve metas e prioridades que configuram suas estratégias para seguir caminhando na experiência.

"Às vezes, um dia ele está mais agitado. O que que você faz? Tenta conversar com ele, dar bastante carinho, fazer um cafuné nele... Ele, às vezes, até acalma. Quantas vezes nós ficamos à noite... Você tenta adivinhar o que ele tem, né? Você tenta adivinhar o que ele tem. Então, quer dizer que nisso, você vai pegando experiência de vida, às vezes você fala: Poxa, deve ser uma dor... Deu uma dipirona, acalmou. Ai você fala: Deveria estar doendo alguma coisa. Depois do caso passado... É isso! O dia a dia vai ensinando a gente a conviver com uma pessoa assim. $\mathcal{N}$ o entanto, quando ele gosta da coisa, ele pisca, né?, correspondendo. É a maneira que a gente conseguiu ensinar ele. Você gostou? Então pisca para mamãe, e ele pisca. Você está bem? Então, é isso, a gente vai aprendendo, o dia a dia ensina, não tem jeito." (F6, mãe)

“(...) e aí você começa olhar assim: infelizmente dias piores virão! Nãa que piore muito do que esteja hoje, mas cada dia, cada dia, como eu falei, é uma novidade, cada dia pode aparecer uma coisa (...) aí vai se moldando. Ah, você não sabe colocar fralda? Você tem que aprender! Você não sabe dar um banho? Você tem que aprender! Você não sabe mexer com ele direito? Você tem que aprender. Tudo é um aprendizado, né?" (F1, mãe)

A família acredita na importância de receberem apoio profissional, quando do cuidado para com o filho no próprio domicílio, a fim de que aprendam a manejar tudo o que se refere com relação ao tratamento dele e com muita segurança. Para a família, este suporte engloba: aprendizado de técnicas, para proporcionar-lhe alívio de sintomas, informações sobre a doença e sua progressão, sintomas que a criança/adolescente possa apresentar, e o que pode ser realizado caso estes ocorram, para que as decisões possam ser tomadas e eles sintam-se seguros em conseguir permanecer em casa com sua criança/adolescente, e o suporte emocional, para que possam se manter firmes e confiantes na longa jornada.

"Se você for ver, é difícil ficar com uma filha assim em casa, porque se ela estava no hospital e tinha uma febre, o médico vinha e fazia, na minha casa não, quem tinha que decidir tudo era eu. Decidir se ia levar no médico, se ia dar aquele remédio, se ia aspirar, se não ia, ia fazer inalação, se não ia, se ia fazer puff... Eu tinha que decidir tudo! Se ela tivesse mais cansada, ia fazer puff, se não, inalação. Então, na minha casa eu era o médico, sabe assim? Eu sentia que 
eu precisava de orientação de como fazer essas coisas com elas. Então, a dificuldade que eu tinha em casa era de fazer alguma coisa e ter medo de acontecer alguma coisa errada e pela conduta que eu tinha tomado. Responsabilidade muito grande, que eu tentava buscar ajuda dos médicos, né?, perguntando, querendo saber o que que eu tinha que fazer." (F14)

Assim, para ter qualidade de vida e se manter segura em casa, precisam sentir-se emponderados para cuidar e oferecer o melhor para a criança/adolescente. A insegurança não possibilita qualidade de vida para a família. Ela abre mão de tudo e passa a viver em função do filho, mas isto não representa má qualidade de vida, porque todo o esforço e sacrifício são recompensados pela possibilidade de sua recuperação.

"Tudo é ele. Você não pensa mais em você e nem nas outras filhas. O seu negócio é pensar nele (...). Poxa, eu tenho um compromisso com a vida, entendeu? Tem uma pessoa que não come (...). Agora, que eu queria ver ele bem, eu queria! Qual é a mãe que não queria ver um filho correndo, Grincando? Mas não foram esses os planos de Deus (...). Então, eu vou cuidar do meu bebezinho até a hora que der certo. Vou ser a melhor mãe do mundo. Agora, a minha vida é dele, não só a minha como a do pai, a das irmãs..." (F6)

O emponderamento da mãe para manter a criança/adolescente em casa vem do apoio, dos elogios e do reforço positivo oferecidos pelos profissionais de saúde do hospital.

"Recebo os parabéns dos médicos, me sinto... Isso..., uma mãe bem..., os médicos falam: 'Poxa, ele é um menino bem cuidado'. Então..., que eu me sinto (...). Eu me sinto assim bem, falo: Poxa, né? Tem pessoas legais que vêm que a gente dá o melhor para ele, pensando assim que a gente vai conseguindo levar, né? A nossa vidinha assim do jeito que dá para ser agora, né?" (F6)

Com o decorrer da doença, convivendo com a condição do filho, a família sente-se segura com a habilidade que adquiriu para manejar 0 cuidado do filho em casa e lidar com as diferentes situações impostas pela doença. Essa segurança vai sendo conquistada à medida que se sente capaz de agir a partir das adversidades advindas da doença. O esforço é coroado quando a mãe percebe que está conseguindo realizar este cuidado de forma satisfatória, corroborando seu empenho em continuar exercendo seu papel de mãe mesmo em uma situação adversa. 
A percepção de que está conseguindo desempenhar suas funções de cuidadora satisfatoriamente é manifesta em função de seu conhecimento em relação à medicação, em conseguir manejar determinada tecnologia da qual a criança/adolescente seja dependente, de perceber que as internações do filho estão mais espaçadas e, principalmente, ao perceber o filho com disposição para realizar atividades do cotidiano ou percebê-lo com os sintomas controlados.

Às vezes, a família sente-se oprimida pela responsabilidade de ter de gerenciar a dor e outros sintomas da criança/adolescente em casa. Ainda assim, prefere fazê-lo, pois esta é uma forma de manter parte do cotidiano familiar e sua autonomia e responsabilidade frente aos cuidados com o filho.

"Meu Deus! Como eu vou mexer nessa criança? Tanto que da primeira vez que ela perdeu o bóton, eu quase fiquei louca, que eu não sabia como fazer. No meio da história, eu já estava trocando a tráqueo e trocando a gastro, né? Trocava tudo! No começo, eu olhava... Para mim, era um bicho de sete cabeças. A primeira vez que eu troquei o curativo da tráqueo em casa molhou o que elas fizeram e elas faziam uma vez por semana. Molhou e eu falei: Hoje, eu vou fazer isso. $\mathcal{E}$ ninguém queria me ajudar. Eu falei: Quem segura para mim para eu trocar? Como vocês seguravam... E ninguém tinha coragem de segurar. Falei: Então, vou fazer sozinha! E eu fiz! A primeira vez não ficou lá aquelas coisas não. Ficou largo, mas, depois, numa 6oa." (F14)

Entretanto, a percepção de confiança é ameaçada diante das consequências que o percurso da doença e dos cuidados paliativos podem ter na vida da criança/adolescente e da família, como o aumento de sintomas e a dificuldade em manejá-los. São intercorrências decorrentes da progressão da doença e, até, o pensamento de que o filho possa vir a óbito. Estes são vistos como uma ameaça à estabilidade da saúde da criança/adolescente e torna a família insegura quanto a como agir efetivamente diante de sinais indicativos dela. Na medida em que a família passa a não ter controle dos sintomas, ainda que aprecie a possibilidade de manter a criança/adolescente em casa, ela passa a conviver com a insegurança de não conseguir oferecer conforto para o filho. Assim, acredita que o hospital é o melhor lugar para manejar a situação neste momento. 
“...) ficar em casa com ele naquela dor toda, sem a gente conseguir resolver, vendo ele sofrer, sabe?, no hospital, conseguia controlar bem mais a dor. Então, por isso que eu te falo que ver ele sem dor, mesmo que no hospital, era melhor do que a nossa vontade de ir para casa (...). A gente conversava muito isso eu e ele e os médicos, sabe? Ficar aqui no hospital foi uma coisa que a gente resolveu tudo junto, com certeza, porque a gente achava melhor ficar do que ir para casa e ter que voltar no outro dia. SNão tinha condições, vai para casa hoje e volta amanhã. Aí perde a medicação, depois tem que começar tudo de novo. O sofrimento físico era muito maior do que a vontade de ir para casa." (F13)

\section{Engajando-se no cuidado}

A família reconhece a gravidade da situação do filho, mas não pode desistir de lutar por ele. Além disso, sabe que o filho acredita que pode se recuperar e também segue firme com o propósito de se tratar e se curar, reforçando a parceria da família com a criança/adolescente. "Engajando-se no cuidado" representa a determinação da família, sobretudo da mãe, em se manter forte frente às adversidades das perdas já sofridas e assumir a luta pela vida do filho. A parceria estabelecida junto a ele é fundamental para manter a esperança da família em afastar a possibilidade de óbito.

Assim, "Engajando-se no cuidado" concentra sua atenção no manejo de sintomas e busca conseguir deter a progressão da doença; sabe que seu grande desafio será guerrear para manter o filho confortável e diminuir seus sofrimentos físico e emocional frente aos desconfortos e incapacidade que vêm sendo submetidos pelo avanço da doença.

"Então, foi assim minha vida com o Vinícius. esses dois anos e meio para cá, eu ter que falar por Vinícius, ter que resolver tudo por Vinícius, ter que tomar atitudes por ele e tentar fazer o melhor por ele. E tipo assim..., uma leoa, né?, defender o Vinícius. de tudo e de todos." (F8)

Ao se engajar no cuidado, a família quer participar do cuidado do filho junto à equipe de saúde. Faz parte de seu papel de mãe protegê-lo. Para isso, como conhecedora absoluta das necessidades do filho, quer sentir-se incluída nas discussões e decisões sobre o seu tratamento paliativo. Mostra à equipe que está pronta para participar do tratamento através de suas observações sobre as condições do filho e que está aberta a tentar empreender seus 
esforços para gerar o alívio do filho de tanto sofrimento, oferecendo sugestões para o controle de sintomas. A mãe vai se especializando para ter certeza de estar oferecendo o melhor cuidado para o filho.

"Eu sinalizei o tempo todo, por exemplo, que o intestino dele estava paralisando, que a dieta não podia ser passada de quatro em quatro horas, porque estava afogando ele. A capacidade do intestino dele estava... Eles acharam que eu estava fazendo uma leitura linear da engenharia, entendeu? E eu sinalizando para eles porem a dieta quando a sonda foi passada, foi direto para o intestino; ele tinha uma absorção maior porque ele tinha uma quebra inicial de proteina. Quando eu falava assim, nós precisamos saber qual que é o percentual do intestino que está funcionando. Eu tenho que reduzir a comida para eu colocar... Eu não posso colocar uma quantidade fechada sem ter isso. Aí eu pergunto: Cađê o especialista do intestino para estudar junto com a nutricionista para sinalizar isso, para fazer o sistema da comunicação de uma forma mais eficaz?" (F7)

"Ele fala para mim às vezes: 'A senhora... outro dia, a doutora estava comigo lá, né? Aí eu falei assim: Doutora, que tal se a gente é... Eu estava falando de passar uma sonda, e ele: 'Não, não... A senhora! Para a senhora tudo está 6om, a senhora não questiona nada!' Eu falei: Meu filho, a sua situação é tão delicada que tudo a gente tem que tentar e sua mãe está aberta para tentar... para tentar pelo menos... em um esforço... Eu, às vezes... Até vai judiar um pouquinho de você, mas num esforço de te aliviar, não de te dar mais dor! O objetivo é reduzir o desconforto, é reduzir a dor para melhora e bem-estar seu." (F7)

Sente-se desapontada quando se percebe sem espaço para expor suas sugestões e auxiliar no cuidado do filho.

“Não custa nada você ouvir, né? Só ouvir! Se você achar que tem fundamento, que tem sentido o que esta LEIGA está falando, apropria, senão, você põe no lixo e joga fora. Não custa nada ouvir, né? Não vai pagar, não vai nada, né?” (F7)

Esse empenho da família pela continuidade da vida da criança/adolescente, impulsionado pela esperança na sua crença de que o filho pode se recuperar, significa também não poder deixar o filho desistir de viver e não deixá-lo desanimar frente às adversidades e perdas decorrentes da doença. $O$ engajamento do cuidado da família precisa estar direcionado a fornecer suporte para que o filho se mantenha fortalecido, não permitindo espaço para que a luta seja perdida. A família sabe que precisa transmitir 
força e segurança para o filho, fazendo que ele também acredite na esperança de que juntos alcançarão a vitória.

"Por enquanto, a dupla está firme, né?, mantendo-se, um fortalecendo o outro e eu tentando segurá-lo junto de mim. Eu tenho isso claro dentro de mim, viu minha filha? Muito claro! (...) vamos até o fim juntos, sempre do lado dele! Mas eu sempre fiquei com ele o tempo todo, e assim nós fomos... Como nós tínhamos falado que nós íamos ser uma dupla, que a gente ia lutar junto..." (F7)

Com isso, cada minuto na presença da criança/adolescente é precioso. A família, desfrutando do convívio com a criança/adolescente, esforça-se para que os sentimentos de apreensão e ansiedade quanto ao futuro, ainda que presentes, sejam colocados em segundo plano, a fim de que ela consiga persistir forte, suportando cada dia com o fardo que lhe é devido e mais nada.

“(...) olha, eu não sei quantos dias de vida eu tenho com meu filho (...) e está assim. É violenta a doença! Eu não sei se eu tenho um dia, uma semana ou um mês! Eu não sei quantos dias que eu tenho com ele. Eu só preciso fazer alguma coisa por ele agora (...), nós estamos vivendo o dia de hoje a cada dia, é mais ou menos isso, minha filha!" (F7)

\section{Vivenciando perdas}

A doença da criança/adolescente acarreta perdas em diversos âmbitos da vida familiar, uma vez que durante a trajetória da doença, família e criança/adolescente vão experienciando perdas físicas, afetivas, sociais, financeiras e emocionais, as quais provocam grande pesar e sofrimento a toda unidade familiar. "Vivenciando perdas" representa a família diante da realidade imposta pela doença e tendo que reestruturar sua vida a partir da elaboração destas perdas.

A unidade familiar perde sua vida cotidiana. Geralmente, um dos genitores precisa ausentar-se do emprego para dar conta das demandas do tratamento e do cuidado com o filho; as perdas financeiras são sentidas, sobretudo, quando percebe que a diminuição destes recursos financeiros pode impossibilitar o provimento de insumos necessários para o cuidado ou o lazer do filho, o que, na sua concepção, coloca em dúvida seu papel de 
cuidador e responsável por zelar pelas necessidades do filho. Para estes familiares, precisar deixar o emprego não é um sacrifício, porque o fazem para poder estar junto ao filho e a recuperação de sua saúde compensaria qualquer coisa. Entretanto, alguns familiares sentem pela perda do suporte que, muitas vezes, encontrava no ambiente de trabalho, onde tinham espaço para que o foco da doença fosse desviado por uns momentos e apoio para se manterem confiantes na recuperação.

“(...) então, agora eu tive que parar de trabalhar né, porque ela está piorzinha! Eu sai do serviço e estou só com ela, mas está bom né, o que que eu podia fazer? Cuidar dela é o mais importante agora!" (F9)

“Eu não me arrependo de ter pedido as contas não sabe (...) só que lá (no trabalho) eu tinha umas horinhas para descansar um pouco minha cabeça né, assim né, de tentar distrair um pouco da doença, eu conversava com minhas colegas assim." (F5)

A perda da saúde do filho e a possibilidade de sua morte interferem diretamente na qualidade de vida destas famílias e de suas crianças/adolescentes, ficando o desejo de que a situação pudesse ser revertida.

"A vida não é melhor porque o problema dela não deixa ser melhor, porque o tempo todo a gente tem que estar preocupado com ela (...). Então, uma qualidade de vida para ser boa mesmo tem que estar tudo 6om, tudo perfeito! Então, não é perfeito, falta alguma coisa: falta a saúde dela de novo! Para ser uma vida 6oa..., se a gente voltasse ao que era antes, ao que a gente sempre teve quando a gente era mais jovem, quando ela era menininha..." (F2)

“(...) que nem, para ele, uma qualidade de vida era o quê? Era poder soltar pipa, ir para a escola com os amigos dele e coisas que para ele acabou completamente, porque ele não quer, ele se recusa ir para a escola, mediante a situação agora, que a gente sabe que pode perder ele, né? Jão tem como querer forçá-lo. Pipa ele não solta mais, porque não pode mais andar! Então, as coisas que ele gostava de fazer, ele deixou de fazer! Então, qualidade de vida é você fazer o que você gosta (...), coisa que você deixa de fazer quando está numa situação dessa, de paliativos. Por mais que você faça, não vai ser os $100 \%$, aí você cai!" (F1, tia)

A criança/adolescente enfrenta a perda de partes do corpo nos casos da amputação, a perda de habilidades e tanto ela quanto a família precisam aprender a viver em um mundo agora transformado por estas limitações. 
A família sofre ao enfrentar as perdas que o filho vem apresentando e sente que está perdendo o controle sobre a doença. Em sua interação com o filho, percebe o quanto é doloroso para ele também se perceber naquela situação, ciente de suas limitações físicas, perdendo sua independência, por vezes a capacidade de se verbalizar. Conscientiza-se de que o filho também se angustia e sofre com suas limitações e, com isso, passa a se isolar do convívio dos demais e constrói seu próprio mundo, criando comprometimento e distanciamento da vida social, o que passa a ser observado também no cotidiano familiar.

A família percebe que essas limitações e perdas sucessivas da criança/adolescente a levam à perda da sua autonomia a cada dia; com isso, todo o sistema familiar tem sua qualidade de vida alterada. A família sabe que as perdas sofridas por ela são compartidas e sofridas conjuntamente.

“(..) quando ele abriu os olhos, que olhou para mim, que ele quis falar, que ele tentou e ele não conseguiu, ele ficou triste, acho que ele percebeu, né? Eu não estou conseguindo falar, né? Ele tentou mexer a mão, também não mexeu, aí foi muito triste! Aí a expectativa que eu estava de alegria, né?, se tornou tristeza, né?, porque ele ficou triste, né?, com a situação. E daí pronto! Foi a partir desse dia que... $\mathcal{N}$ ossa! Eu..., eu tinha certeza que ele não aceitava, né?, essa incapacidade de falar, de se mexer... Então, eu tenho certeza que se o câncer tivesse sido em outra parte do corpo, ele tinha aceitado muito melhor e eu também." (F8)

“(...) agora está sendo tudo muito rápido, cada dia que você vai assim no médico é uma coisa que aparece nele... Daí agora está difícil para cuidar, porque antigamente ele subia essas escadas correndo, descia... Agora não, né? Agora só é deitado no sofá, na cadeira (...), porque... igual... Para nós, é difícil, né? Mas e para ele?, (...) que numa semana ele andava, falava que doía, mas andava. Daí na outra semana, ele já parou de andar, daí na outra semana já começou usar fralda, quer dizer que... Como fica isso para ele?" (F1, mãe)

"(...) eu, às vezes, acho que até ele não aceita a situação, acho que ele acabou criando o mundinho dele e está vivendo naquele mundo." (F1, tia)

Ao se dar conta que a doença altera a capacidade de comunicação e expressão verbal de suas crianças/adolescentes, a mãe sente-se frustrada e angustiada com a situação por perceber que o filho não consegue revelar 0 que sente e o que o incomoda. A mãe percebe-se, então, impotente por não 
se ver com recursos de auxiliá-lo a se livrar de eventuais desconfortos e sofrimento, precisando, pois, desenvolver estratégias e novos meios de conseguir se comunicar com o filho. Nessa missão, passa a focar suas atenções em gestos faciais e emissão de sons que possam sugerir algum desconforto e, dessa forma, vai encontrando novas estratégias para se comunicar com a criança/adolescente, descobrindo e retirando a causa do que lhe aflige. A partir destas perdas, a família aprende uma nova forma de se relacionar e interagir com o filho.

“(...) parece 6obagem, mas gente, a gente se entende assim, tem uma sintonia assim muito 6oa no olhar, sabe? Ele olha muito para mim assim e é uma coisa assim muito, muito (...), eu não sei nem explicar, sabe?, misteriosa, sabe? (...). Então, é o único meio que eu achei para me comunicar com ele e para saber realmente o que ele estava sentindo, entendeu? Sempre estou conversando com ele, sempre estou tentando entender o que o olho dele está querendo me dizer, de manter mesmo esse contato e de adivinhar tudo, né?" (F8)

Nesta árdua caminhada, a qualidade de vida da família está intrinsecamente relacionada ao bem-estar do filho. Sabem que são os responsáveis pelo cuidado do filho e, por isso, precisam ser e estar fortes para atender as responsabilidades e demandas adicionais de cuidados da criança/adolescente doente, sobretudo em casa. Ao se encontrar mantendo a criança/adolescente em casa em cuidados paliativos, os familiares começam a conviver de perto com a perda do controle dos seus sintomas e a possibilidade real de perda do filho.

"Para dormir, ele está dormindo sentado, ele não dorme mais deitado, ele dorme sentado. Mas por quê? Porque se ele dormir deitado, eu acho que deve dar falta de ar ou canseira, alguma coisa, e ele fica com medo. Então, assim, ele se limita em muitas coisas, não deixa nem tentar por medo. Ah! Eu... Eu acho que seja medo! $\mathcal{E}$ assim... E a gente tenta fazer, dentro dos nossos limites, o que pode, o que dá para ser feito para ele (...), mas até para gente dormir é difícil, fica dormindo pensando: $\mathcal{N}$ ão tem jeito! É difícil!" (F1, tia)

Ao ser defrontada com a progressão da doença e de começar a vivenciar as perdas decorrentes desta, a família começa a perceber que o seu projeto de vida junto ao filho pode estar sendo perdido e que seus sonhos e expectativas para o futuro dele podem não ser realizados, 
colocando frente a seus olhos a possibilidade real de que ela se defronte com sua maior perda: a morte do filho.

"O Paulo vai fazer computação. O Paulo vai estudar, vai trabalhar, num sei que... Daí vem e volta tudo de novo e agora vem pior. Eu queria ver crescer, ver formar, ver casar, ver neto, de ver tudo (...) e vem isso agora e a gente pode não ter mais nada disso lá na frente, né?" (F1, $m \tilde{a} e)$

Quando encontra continência para falar sobre suas perdas com a equipe de saúde consegue reconhecer que os cuidados paliativos podem ser a estratégia que precisavam para poder lidar e enfrentar com a situação que se instaura à sua frente. Constatar que por meio destes cuidados pode conseguir o conforto do filho faz com que a mãe sinta-se segura de que está tomando uma decisão acertada em relação a estes cuidados.

"O doutor sim, ele sim explica, sabe? Ele explicou tudo direitinho, sabe? Ele falou: 'A senhora sabe como ela está! Sós não estamos conseguindo controlar a doença, a dor! Eles são preparados para isso, não existe só a morfina, existe uma série de remédios depois da morfina', ele falou para mim, né? Isso me deu calma, sabe? Eu confiava nele, eu confiava que ele ia fazer o melhor para minha menina." (F11)

\section{RECONHECENDO OS CUIDADOS PALIATIVOS}

RECONHECENDO OS CUIDADOS PALIATIVOS é a contingência do processo no qual a família vive a incerteza entre a possibilidade de cura ou a morte da criança/adolescente. Reconhecer que a criança/adolescente não pode mais ser curada, que a doença progride, que a nova meta deve ser a qualidade de vida e o controle de sintomas físicos ocasionados pela progressão da doença e desordens emocionais decorrentes deste processo permitem à família seguir em frente na experiência de perdas. É um caminho permeado pela angústia, pesar, mas, sobretudo, pela esperança de poder, ainda, desfrutar algum tempo a mais com o filho. O objetivo da família ao reconhecer os cuidados paliativos é mantê-lo vivo o maior tempo possível, mas com a garantia de que ele também viva da melhor forma, sem sofrimento físico e emocional. Portanto, busca concentrar esforços e energia e, ao aprender a viver um dia de cada vez, procura não pensar nas consequências que a doença 
possa trazer para a criança/adolescente e para o sistema familiar até o momento em que percebe que a criança já demonstra sinais de cansaço de seguir adiante e passa a reconhecer que ela está morrendo.

Esta categoria está constituída pelas seguintes subcategorias: "Aprendendo a viver um dia de cada vez" e "Perdendo a parceria com o filho".

\section{Aprendendo a viver um dia de cada vez}

À medida que se percebe MANEJANDO A NOVA CONDIÇÃO, a família começa a se dar conta que a doença pode progredir, o que vai ficando visível à proporção que aumentam os sintomas físicos e passa a reconhecer alterações no corpo e no estado emocional do filho.

Para a família, a clareza e consistência nas informações trazidas pela equipe durante toda a trajetória da doença favorecem o reconhecimento do estado clínico atual e, consequentemente, a permite reconhecer os cuidados paliativos como uma nova estratégia de cuidado para o filho que lhe garanta alívio de sofrimento e proporcione melhora em sua qualidade de vida.

"Nós estamos cientes que a gente pođe perder ele, não pela deficiência, mas por infecções que pode pegar e vir afetar ele e levar até a morte. É uma coisa que (...) a gente estava sempre conversando, os médicos sempre iam preparando a gente, sabe? E é uma coisa que todo mundo lá de casa entende, que todo mundo, às vezes, chora junto. Sabe, a gente está ciente, mas a gente não quer acreditar que é aquilo mesmo." (F6, mãe)

Outro aspecto que ajuda na compreensão e organização dos fatos é a convivência com a criança/adolescente. Acompanhar a piora clínica da criança dia a dia faz com que a família passe a se conscientizar de que o controle da doença está cada vez mais difícil.

“Agora está sendo tudo muito rápido, cada dia que você vai, assim, no médico é uma coisa que aparece nele. Daí agora está difícil para não perceber que a doença está vindo com tudo, né? Está sendo difícil para cuidar." (F1)

Consequentemente, sentindo a progressão da doença presente em suas vidas de forma cada vez mais acentuada leva a família a aprender a viver um dia de cada vez para seguir cuidando do filho. Sabe que precisa 
viver com ele o hoje, pois o futuro é incerto e só Deus sabe quando e como ocorrerá seu desfecho. A partir de então, resolve que viverá intensamente com a criança/adolescente, é o modo que encontra para seguir a experiência e aproveitar a oportunidade por ainda tê-la junto dela.

"Nós vamos vivendo um dia cada dia, né? O que a gente queria mesmo é que ele tomasse os remédios e melhorasse, mas vamos ver o que Deus quer, né?, porque a gente quer uma coisa e Deus quer outra!" (F1, mãe)

"Por mais que ela esteja assim, eu quero que ela dure o tanto que Deus quiser. Só que no dia que Deus quiser, eu vou... eu vou me sentir a mãe mais privilegiada do mundo, que eu dei amor, carinho e cuidei. Não abandonei, que é essa a parte mais 6oa, é você não abandonar." (F5)

"Eu sempre vivi com ela de uma forma muito intensa, sempre o hoje como se fosse o último." (F14)

Assim, a família foca sua trajetória no presente e bloqueia a existência do futuro em suas vidas; não pensa nele, pois este os remete a assumir a morte da criança/adolescente e a pensar a vida sem a presença física do filho e isto não pode ser imaginado e aceito. A família sabe que o futuro pode ser catastrófico com a morte da criança, e procura, assim, não fazer planos para o futuro. O futuro os remete para a incerteza sobre o tempo de vida que ainda resta ao filho. A família reconhece que para não perder o equilíbrio das suas forças para cuidar da criança/adolescente e preservar a qualidade de vida, ela precisa ter o foco no presente. Este, para elas, é representado por sua luta para tolerar a situação, enfrentando desafios diários, onde passa a vivenciar cada momento em seu devido tempo, desenvolvendo paciência para vencer um passo de cada vez de um percurso que não sabem a medida, mas esperam que ainda seja longo. O presente é precisar dar conta das alterações e intercorrências que ocorrem com seus filhos dia a dia, procurando diminuir sequelas e tentando brecar a evolução da doença.

Enquanto fisicamente o declínio da criança/adolescente não é tão visível aos olhos da família, ainda pode existir a esperança de recuperação. Essa aparente normalidade torna mais fácil acreditar que o paciente ainda está bem e poderá sobreviver por algum tempo com a família, que segue na esperança de conseguir manter o filho vivo. 
Nas histórias apresentadas, a compreensão de que realmente a doença está avançando, apesar de seus esforços, e que o filho está morrendo, começa a acontecer quando os membros familiares passam a reconhecer o declínio da situação clínica da criança. A família, que sob o impacto de receber a notícia de que o filho estava em cuidados paliativos, vivia a desconfiança de que a equipe estava enganada em seu diagnóstico, agora passa a ver que o filho está diferente. Os declínios físico e clínico começam a se projetar acentuadamente frente aos seus olhos.

“(...) que da primeira vez, ela emagreceu de uma vez, depois parou. Ai acabou o tratamento, ela voltou ao normal, e entre uma químio e outra, ela dava uma engordadinha. $E$ dessa vez não, ela continuava magra a mesma coisa, e então eu falava: $\mathcal{A}$ doença está aí! Voltou! A partir do momento que você vê que o tratamento não estava mais dando resultado nenhum, você começa ver que, da outra vez, quando ela começou a fazer o tratamento, ela fez a cirurgia e ela saiu, e nesse outro tratamento não aconteceu nada! Eu não estava vendo nada, resultado nenhum, nenhum resultado! Ela estava emagrecendo, emagrecendo... Eu falei assim: Oh, o tumor está aí! Ai eu já sabia, sabe? SNão acertava um remédio, um remédio, não tinha nada." (F11)

A mudança na aparência física da criança/adolescente significa um declínio na sua condição. Pode perder peso, ficar mais fraco, com mobilidade reduzida ou incapacidade mental. A família percebe que o seu estado de saúde é instável quando não a vê mais como era antes, percebendo, assim, que ela já não reage mais ao tratamento. Observar a piora progressiva da criança/adolescente e o seu estado frágil fazem com que tema que a situação realmente não se reverta. A progressão de sinais e sintomas decorrentes do avanço da doença e consequente perda da capacidade da criança de funcionar independentemente aumentam a angústia e o pesar das famílias.

"É a ficha completa, porque eu tinha uma esperança disso ficar estacionado, dela não sentir tanta dor e continuar andando, sabe? Mas, naquele sábado que eu vi ela daquele jeito, ela não conseguia ficar de pé (...), parecia um boneco mamolengo, toda mole, sabe? Então, assim... Aquele dia que eu... Aquilo... Nossa! Me abriu o chão." (F3)

Nesse momento, começa a perceber que a criança/adolescente poderá não se recuperar, mesmo que ainda lhes custe admitir isso. Para as 
famílias com filhos portadores de doenças oncológicas, os exames indicando metástases a deixam apreensiva e cada dia mais preocupada com a real possibilidade de que não se consiga a cura da criança; observam que a doença toma conta de sua criança/adolescente e de suas vidas a cada dia.

"Na verdade, foi fazendo o tratamento, mas foi aparecendo, foi onde que eu estava falando que a metástase é ruim por causa disso. Na verdade, as pessoas que eu conheço que tem câncer, depois que vê metástase, você fica muito mais apreensivo, porque, às vezes, o organismo não responde ao tratamento, é como se tivesse dando uma vitamina" (voz enfática). "(..) acabou voltando em muitos lugares, porque, além do joelho, veio no rim, aí tirou, aí apareceu no pâncreas, tirou, apareceu no pulmão, tirou... Ele fez duas vezes cirurgia no pulmão, tirou da costela... Coisa assim... que não tinha aparecido da primeira vez, né? (...) e a doença está lá, infelizmente comendo ele a cada dia". (F1, tia)

Fazer parte de um grupo ambulatorial de cuidados paliativos coloca a família frente à ambivalência de sentimentos de esperança e angústia. Se, por um lado, se depara com crianças que vêm tendo a sua doença controlada e com os sintomas controlados, por outro, encontram-se frente à piora progressiva e com a morte de outras crianças do grupo. Nessa situação, ao comparar o que vê com o quadro que está acompanhando do filho nos últimos tempos, conscientiza-se de que o filho realmente não sobreviverá.

Esse é o contexto que auxilia que a família vislumbre o futuro da criança. As visitas ao ambulatório fazem com que a mãe se defronte com a morte iminente do filho ao ver outras crianças/adolescentes na mesma condição, ou seja, morrendo. Assim, ela vive a incerteza em relação à piora dos sintomas e o tempo que the resta junto à criança/adolescente. Ainda que reconheça que a criança/adolescente sofra menos com os cuidados paliativos, ela não consegue pensar sobre o futuro de seu filho.

“É. Tinha um pai lá, sabe?, falando: 'Ai, graças a Deus, minha filha já está terminando o tratamento de dois anos de leucemia, né?', que também estava sempre lá com a Diana., né?, lá no hospital (...) Então, aí passou uns dias, a menina já estava na cadeira de roda, depois de uma semana também foi embora, sabe? Eu falei: meu Deus, como pode? Morreu! Estava quase terminando e foi embora, quer dizer, não tem jeito!" (F11, pai) 
A interação das famílias de crianças/adolescentes em cuidados paliativos com o ambiente hospitalar as coloca em contato direto com situações de sofrimento e processo de final de vida de outras crianças/adolescente e seus respectivos familiares. Desta feita, passam a se identificar com as situações observadas, reconhecem a dor e o sofrimento vivenciado pelos familiares que estão perdendo os seus filhos e passam a vislumbrar nesse contexto a provável morte do seu filho. Conhecer as histórias de outras famílias as faz perceber que esta perda pode constituir-se em uma experiência doída e solitária, ao mesmo tempo em que as ajuda a reconhecer a realidade que vivenciam. Ao se ver frente à dor do outro, a mãe encontra um espaço para viver suas próprias dores e temores diante da luta que vem travando pela vida do filho; também se percebe sem um espaço onde possa expressar seus temores e angústias frente à proximidade da morte deste ente que lhe é tão querido.

“(...) eu vi uma mãezinha assim” (suspiro), "em fase terminal. Eu assisti de longe, né?, toda a etapa dela e o último dia dela sair (...). E a hora que eu vi a mãezinha saindo assim com as coisinhas, primeiro foi a avó, levando as coisas para casa, aí depois eu vi ela (...). Depois que a criança partiu, ela olhava para tudo como se tudo fosse muito vazio, né? E aquilo doeu na minha alma, aquilo ficou preso aqui em mim, aquele silêncio, sabe?, e aquela... aquela ida sozinha, né? Então, como é que eu recebo e também como é que eu faço uma boa despedida, uma despedida agradável? Assim, eu conseguia ler os olhos dela assim... um desejo de agradecer talvez as enfermeiras, agradecer alguém e ... assim, muito frio, sabe?, sutil, sabe?, muito assim... Eu consegui sentir essa dor dela, sabe? Posso não estar sendo verdadeira, mas foi que eu captei, né?” (F7)

A família também vai captando que as conversas médicas estão se tornando diferentes. As colocações que têm de ser feitas com a equipe médica passam a ser longe do quarto da criança/adolescente e muito pouco é falado em sua presença. $O$ tema sempre vem iniciado com a verbalização de que a doença já não responde mais ao tratamento e que avança cada vez mais.

"Hoje a doutora conversou comigo de novo (...). Me levou lá para a salinha, né? (...) quando ela chama para conversar longe dela, 6oa coisa não é, né? A doença está aí né, forte, nem sei o que te dizer!" (F10) 
As conversas incluem as informações referentes às mudanças físicas e emocionais que a criança/adolescente pode começar a apresentar como efeito da progressão da doença, algumas das quais já podem ser verificadas pela família. As alterações, sobretudo no físico da criança, ressaltam aos olhos da família, fazendo com que o processo de final de vida não possa mais ser negado.

"A doutora entrou lá no quarto hoje, né? A gente estava conversando do xixi e ela falou: 'Oh mãe, ele fez pouco xixi'. Ai ela falou assim: 'A senhora sabe que vai ter mudanças, vai ser no xixi, né? Então, o tumor já vai começar a afetar os órgãos'. Para mim, é muito apreensivo, né? Para mim, ver essa situação vai ser muito duro! Eu já estou vendo um lado, o lado que ele mexia já não está mexendo direito, ele não tem coordenação, sabe? Já não é mais a habilidade que ele tinha." (F8)

"Então, está sendo difícil! $\mathcal{A}$ doutora me falou assim dos sintomas que ele vai sentir, né? A partir de agora, dessa fase final da doença e que eu já estou observando nele há dias, né?, assim que ele vai ter inchaços nas juntas, e a gente vai observando e vendo que já está tendo isso; é o sinal que está estreitando tudo, né? Eu não queria perceber esses sintomas, minha filha, mas eles estão brotando na frente dos meus olhos." (F7)

Agregado a isto, sobretudo no período de internação, a família sente que a equipe altera seu comportamento frente à situação da criança, assinalando que também sente por não poder salvar a vida dela. Algumas normas hospitalares começam a ser quebradas pela equipe, como: liberação de visitas, permanência de mais acompanhantes junto ao leito e autorização para que a família traga os alimentos da preferência do filho e que, muitas vezes, não estão disponíveis no hospital. Estes são sinais que vão indicando para a família que o seu tempo com a criança está se esgotando.

"Eu sou muito observadora neste ponto, é, eu entendo muito bem othar da pessoa, às vezes não precisa me falar. Então, eu percebia que os médicos estavam tratando diferente, o olhar deles era diferente para a Judite!É assim, oh, vamos cuidar, vamos dar carinho, tipo assim, vamos deixar ela confortável. Deram um quartinho só para ela... É um olhar, eu não sei te dizer como é que é, mas eu sei qual é o olhar, entendeu? Não é, é até sem querer (...) Lamentação talvez, de Camentação, de pena não! Lamentação sabe, ou inconformismo, sabe assim, de que, aí nem eu acredito! (F12) 
"Já estavam colocando, não sei como que chama... aquelas placas que a gente coloca para não virar ferida... deixaram meu outro filho ficar direto aqui comigo. Então, ali eu já sentia, meu filho não tem mais jeito!" (F13)

O processo de ir reconhecendo que a possibilidade de perder o filho é real acontece com o decorrer da trajetória e há divergências entre os membros familiares sobre a realidade do óbito. Os familiares parecem escutar as informações sobre o estado da criança/adolescente por meio de diferentes filtros, o que os leva a encontrar diferentes significados, podendo conduzir, consequentemente, a conflitos familiares. As famílias vão se dando conta da irreversibilidade do quadro em momentos diferentes na trajetória. $O$ tempo da mãe nem sempre é igual ao do pai, bem como entre outros membros da família.

"Um dia, eu estava indo lá para o Extra com meu marido. Eu falei para ele: quando a Diana. morrer, eu vou enterrar ela em Minas. Nossa! Meu marido quase enfartou dentro do carro! Eu falei: não tem jeito mais, a Diana. está indo embora! Nossa senhora! Ele ficou doido comigo, sabe?" (F11)

"Ele" (pai) "foge muito! Ele tem dificuldade para encarar, mas ele sabe que é grave, ele sabe que o menino está desenganado. Todo mundo sabe que o menino é desenganado, que o prognóstico dele não é 6om. Eu sempre falo a verdade. Otha, hoje ele está com muita dor, hoje ele está com a barriga bastante inchada, a químio não deu resultado, o tumor voltou a crescer, entendeu? Quer dizer, ninguém vai ser pego de surpresa, nada, né?" (F7)

Em algumas famílias, somente a mãe reconhece a gravidade do estado da filho e acredita que os demais membros familiares sabem da realidade do quadro, mas que não aceitam a situação, razão pela qual preferem não falar sobre o assunto como uma defesa para fugir à realidade que os aproxima do óbito dela. A mãe percebe esse comportamento como a forma encontrada por eles na busca de retardar o acontecimento da morte da criança/adolescente, que, a cada dia, se faz mais presente ou, mesmo, negar que a situação exista em suas vidas.

"Diana está muito ruim! Eu falava para minha família: $\mathcal{A}$ Diana. não tem mais jeito não (...). Ninguém aceitou! Ninguém aceitava e eu falava: gente, a Diana não está 6em, a Diana. não 
tem condições de ficar mais, a Diana vai embora, ela tem que ir embora. Ninguém acreditou! Todo mundo estava vendo, mas ninguém aceitava. Fingia que não estava vendo, sabe? $\mathcal{E}$ por quê? Porque não aceitava. Não tinha mais condições. E ninguém queria tocar no assunto, porque ninguém queria que ela... Ela não podia ir embora! Imagina a nossa Diana ir em6ora!" (F11)

\section{Para algumas famílias, RECONHECER OS CUIDADOS PALIATIVOS} significa perder a possibilidade de cura do filho e, com isso, perder também a sua estrutura familiar completa. Embora, por um lado, a família perceba que o estado do filho se agrava ou que ele, de fato, está morrendo, evita entrar em contato com a dura verdade. Eles tentam redirecionar pensamentos e sentimentos mobilizados pela proximidade da perda para outras atividades que a façam esquecer esta árdua fase; para isso, focam sua atenção no cuidado à criança/adolescente e a alegria de ainda poder têla ao seu lado. É a forma que encontra para afasta-se da dor de perceber que ela está indo embora e que nada mais se pode fazer.

“(...) o medo, medo da perda! Isso foi uma das coisas que eu mais Gutei, sabe? Lutei muito e ainda luto (...), porque a gente estando aqui dentro passa tudo pela cabeça da gente mesmo, né?, principalmente quando está numa situação às vezes grave. Então, a gente pensa em tudo, né? Pensa na perda... A gente não quer, Lógico, perder, né? Nisso eu sou assim até hoje. Estou firme aqui para não perder ela." (F5)

"Eu tinfia que estar feliz porque ele me obrigava a ser feliz. Eu estava ali com ele, não estava? Eu tinha que estar feliz, porque ele me obrigava a ser feliz! Então, eu tinha que estar o tempo todo sorrindo, eu fazia brincadeira com tudo. Mas, lá dentro, assim..., acabada lá dentro, sabe?, mas o tempo inteiro sorrindo, inventando coisa para fazer, indo na casa das tias, procurando coisa para fazer... E era isso!" (F15)

É uma estratégia, onde os próprios familiares buscam se enganar sobre a veracidade que se projeta à sua frente; e é isto que lhes permite manter a esperança na recuperação do filho e continuem sonhando que ele permaneça ao seu lado. Eles seguem a vida à espera de um milagre que os remeta à possibilidade de um futuro na presença do filho. Manter esta crença é fundamental para que prossigam o cuidado para com a criança e mantenham a integridade do sistema familiar. A esperança na sua recuperação é mantida até o momento da morte. 
“Eu não punha na cabeça... Eu sabia que ela ia embora, mas não punha na cabeça. Eu não punha na cabeça que ia viver sem ela, sabe? N Nunca pus na cabeça. Até hoje eu não... Acho que não caiu a ficha ainda que ia viver sem a Diana., sabe?" (F11)

“(...) eu já sentia: Meu filho não tem mais jeito! Mas eu estava assim, eu sentia dentro de mim, mas eu nunca passei para ele. Eu estava assim, sempre confiante com ele. Você vai ficar bem, amanhã você vai amanhecer melhor, sabe? Sempre assim, animando ele. Mas, para mim em si, eu sentia que podia perdê-lo, mas, com certeza, eu mantive a fé até o último dia. Até o último momento, eu ainda pedi para médica: Pelo amor de Deus, faz alguma coisa! Mas ali ela já não tinha mais o que fazer!" (F13)

"Eu via meu filho sendo consumido pela doença. Nossa! Eu sabia que ele estava morrendo, sabe? E apesar de sentir isso no coração... Mas eu achava que eu estava enganada, sabe? Quando você quer, você mesma quer se enganar! Você não quer pensar nisso, mas está dentro de você." (F15)

Contudo, o avanço gradual e agressivo da doença deixa a família desanimada e esta começa a atinar que não pode mais fazer muita coisa para impedir sua progressão. Constata que, apesar de sua esperança e de seu empenho em esforços, criança/ adolescente e família encontram-se reféns da situação de doença e cuidados paliativos.

“Até porque, como eu falei, cada dia é uma novidade e, infelizmente, não é uma novidade para melhor, entendeu?... que nem a paralisia aumentou. Ele não estava comendo, ele voltou a comer? Ele voltou a comer por causa do remédio que ele está tomando, mas ele está todo inchado por causa desse remédio. Então assim, você não vê uma melhora em nada, você vê assim... É um caminhinho que ele está, né? Tem que passar, mas sem nem um ponto totalmente positivo assim que você fala... Sossa! Hoje ele está legal! Ele está melhor, ou ele tentou soltar uma pipa, entendeu? Não tem mais isso!" (F1, tia)

"Eu percebia que a cada dia que passava ele tava pior. Eu ali dentro do hospital, parecia que eu estava com as mãos amarradas. Eu tinha que dar comida na boca dele, porque ele já não estava mais comendo sozinho, não tinha forças, já não queria comer mais nada. A 6arriga daquele tamanho, banho na cama... Já estava formando, sabe?, aquelas feridas do lado, assim, dele ficar deitado, nas costas ele já tinha." (F13) 


\section{Perdendo a parceria com o filho}

"Perdendo a parceria com o filho" representa a família, sobretudo a mãe, reconhecendo que a doença está mesmo avançando e que o filho está, de fato, morrendo e passa a entender as mudanças que resultam com esta consciência. A percepção da perda desta parceria ocorre quando se conscientiza que o filho perdeu a vontade de continuar lutando pela vida. Ao perceber que o processo parece ser mesmo irreversível, que não pode mais controlar a doença, sente-se fracassada e angustiada por não conseguir fazer mais nada para alterar o final dessa história. Compreender que não pode mudar o rumo da doença e que esta levará o filho a óbito gera frustrações e sentimentos de impotência, em que a tristeza, o medo, a raiva e outros sentimentos muitas vezes se acentuam. Ao se perceber perdendo sua parceria com o filho, perde também a esperança de que consiga tê-lo a seu lado por muito mais tempo.

À medida que vai RECONHECENDO OS CUIDADOS PALIATIVOS, a mãe vai verificando que as chances de recuperação vão diminuindo. Mesmo assim, apesar de o estar vendo enfrentar vários desconfortos físicos decorrentes da doença, acredita que estes possam ser contornados e aliviados via medicamentos e internações. Enquanto conseguem manter 0 controle de sintomas e perceber o filho confortável, continuam demonstrando sua força para o enfrentamento da situação. Assim, ainda que reconheça a morte iminente do filho, a mãe permanece engajada em oferecer o melhor cuidado ao filho, porque também percebe que este está confiante na sua cura e empenhado em atingir este objetivo.

"O Rafael só está do jeito que ele está por obra do Espírito Santo! Isto é por obra de Deus, viu minha filha?, porque ele luta, ele luta... ele luta com unhas e dentes! Na hora que se pensa que ele vai se abater, ele ressurge do nada e ele se mostra forte, forte de verdade e ele não é só o mostrar não, mas ele está forte sim, ele reage de uma forma assim, quando ele pede para mim ajudá-lo, ele fala: 'Mamãe, me ajuda (...)', por exemplo. É chegar para o médico e falar assim: Doutor... Porque... Como que essa dor ... É tentar provocar ele (médico) para que eles tenham um entendimento, que tentem ler o Rafael. como indivíduo." (F7)

Existe uma parceria incondicional entre mãe e filho que mantém acesa a esperança na possibilidade de recuperação do filho. É a consciência 
dessa parceria que mobiliza a mãe a continuar lutando pela vida do filho e enfrentar com determinação o desafio a ela imposto com a possibilidade da sua perda, apesar de toda dor e sofrimento que toda a família vem enfrentando. $O$ pacto de que lutariam juntos contra a doença foi estabelecido no momento do diagnóstico e fortalecido durante toda a trajetória da doença.

"Quando a gente descobriu, eu falei para ele: Vamos formar uma dupla? Vma dupla para gente lutar JUNNTO! Então, a gente está fazendo isso. E vamos até os últimos instantes, né minha filha? Como uma dupla (...); nenhuma mãe deseja passar por uma situação dessa! Mas ela existe diante de mim e eu tenho que encarar, né? Eu não sou de fugir de desafio, sabe? Mas $\mathcal{N} \tilde{A} O$ é fácil não filha! Nãa é fácil! Mas a gente tem que estar firme com ele e enfrentar o desafio!" (F7)

Essa relação de proximidade e cumplicidade desenvolvida com o tempo de tratamento cria também uma forte confiança na figura materna de protegêlo. A mãe acredita que nesse momento de profundo sofrimento, angústia e pesar, a proximidade e parceria com o filho sejam evidentes e marcantes e é o que permite que continuem juntos, engajados na batalha pela vida.

"Porque ontem ele estava assim meio angustiado, com muita dor... Ele só falava para eu Cargar tudo e ficar só sentada na frente dele, cantando para ele e passando a mão nele até ele dormir. Eu fui até três da manhãa, três e meia fazendo isso." (Risos). "É a única coisa que eu posso estar fazendo, né? E eu vou continuar fazendo por muito tempo ainda, se Deus assim permitir." (F7)

Contudo, vendo que não pode controlar a doença, a família defronta-se com a sua impossibilidade de reverter a situação do filho e acompanhar o seu sofrimento físico e emocional diário, sua dependência lhe causa imensa dor. Ao constatar o filho lúcido e consciente de sua situação, vivenciando sua deterioração progressiva a cada dia a machuca ainda mais. É isto que determina o início de seu reconhecimento de que está perdendo o filho para a doença.

"Ainda mais ele... nesse quadro de lucidez! Porque você vê que quando o quadro é de um coma..., alguma coisa assim..., mas não é o caso dele, é da total lucidez, entendeu? Da consciência, por exemplo, é isso que dói muito. Dói muito, dói muito saber que ele está partindo e que ele sente todo esse sofrimento que o corpo põe para ele, sabe? Machuca lá no fundo da minha alma e eu não posso fazer nada, eu só posso estar aqui, juntinho dele, né minha filha?” (F7) 
Nessa trajetória, à medida que comprova a fragilidade física, mas principalmente quando se dá conta do sofrimento emocional do filho percebida mediante sua falta de vontade de viver, falta de forças, desesperança e não vendo mais sentido para seguir sua vida, a família percebe que a sua parceria com o filho está chegando ao fim.

"Eu percebia que cada dia que passava assim, ele estava..., ele estava PIOR! Eu tinha que dar comida na boca dele porque ele já não estava mais comendo sozinho, não tinha forças... Já não queria comer mais nada.Só queria dormir, ficava lá, na cama, sem vontade de nada" (F13)

O cenário que se abre à sua frente é o de precisar testemunhar 0 sofrimento do filho e não poder mais evitar ou minimizá-lo. Percebe-se imobilizada diante da sua impossibilidade de tirar o filho dessa situação e se conscientiza que o filho já não suporta mais viver dessa maneira. Neste ponto, a mãe reconhece que sua criança está cansada de lutar contra a doença, não encontra mais forças e sentido para continuar vivo frente a tantas limitações e sofrimento.

"A dor que a gente sente como mãe é a dor da impotência! Essa dor da impotência dói tanto que você nem imagina!" (pausa) "E... É assim, eu não consigo, eu não saberia quantitativamente..., eu não saberia dar uma dimensão de valor para você..., em absoluto! E mesmo que... Eu não sei em termos qualitativos, mas eu sei que é uma dor, uma dor, uma dor muito profunda!" (F7)

Algumas crianças ainda encontram espaço para dizer à mãe o quanto aproveitaram a vida e que se sentem cansadas para seguir adiante. Assim, a mãe reconhece que continuar insistindo no tratamento pode apenas aumentar o sofrimento da criança.

"Ela falou: 'Mãe, está na hora deu ir embora (...). Preciso ir embora, está na hora deu ir embora, né? Chega, não aguento mais isso, mãe! Está 6om já, né? (...) a mãe não quer entender que a minha missão está terminando." (F11)

Assim, a família percebe-se impotente frente à situação e toma consciência que nada mais pode fazer pela criança. Ao admitir para si que o filho já não pode mais seguir lutando e que o seu sofrimento aumenta dia a dia, torna-se impossível negar a morte. Ela passa a vislumbrar a morte como forma de aliviá-lo daquela dor. 
"Mas a Diana estava precisando ir embora, não tinha condições da Diana ficar mais, sabe? Ela precisava descansar!" (F11)

Reconhecer os cuidados paliativos não é aceitar a morte do filho, mas sim uma forma de poder prosseguir na vida acreditando que isto é o melhor para ele diante do sofrimento físico e, principalmente, emocional que ele enfrenta. Contudo, reconhecer os cuidados paliativos neste momento que se vê perdendo a parceria com o filho coloca a mãe entre o paradoxo de aceitar o desejo do filho em desistir de seguir lutando pela sua vida e o seu desejo de mantê-lo vivo.

“(...) as coisas vão se afunilando (...). Ele só quer dormir, não quer comer, a respiração está mais cansada e eu aqui, olhando tudo isso, sem ter muito o que fazer (...). O que toca às vezes para mim é..., às vezes, ele tem uma dor e eu não puder tirar aquela dor, mesmo ele partindo, mas eu tirando aquilo para que ele pudesse ... se..., entendeu? É só isso e mais nada, minha filha!" (F7)

Perdendo a parceria com o filho representa o final da esperança da mãe em mantê-lo vivo. Ao se dar conta que a morte dele é iminente, a mãe sente-se aliviada, porque sabe que esta é a única forma de vê-lo livre do sofrimento que o consome, mas tem a consciência da dor e dos sentimentos de perda que esta ausência provocará em sua vida e na vida de sua família futuramente. Dessa forma, seu único desejo, no momento, é que a morte ocorra sem sofrimento adicional.

“(...) a gente não quer, lógico, perder, né? Nisso eu sou assim até hoje, mas é... Penso muito nela também... E é quando eu falo assim com Deus, eu falo para Ele não pensar em mim, pensar nela, que eu não quero que ela sofra; uma das coisas que eu não admito, não quero, é o sofrimento dela! Ela estando bem, eu estou bem, se ela está com dor, eu estou com dor também. Então, a minha pior dor do mundo é a dor dela, né?, que eu não aceito! Eu não aceito! SNossa! É uma das coisas que eu mais falo na minha vida: eu não aceito dor, não aceito sofrimento! Mas se for para ela ficar sofrendo, eu prefiro que Deus leve, sabe? (...) quando eu falo assim com Deus, eu falo para Ele não pensar em mim, pensar nela, que eu não quero que ela sofra. Vma das coisas que eu não admito, não quero é o sofrimento dela!" (F2)

“Eu só peço a Deus, todos os dias, para livrar ele assim... Eu só tenho pedido para Deus... É, eu peço muito para Deus, assim, se Deus puder levar ele dormindo, com todos os órgãos 
funcionando, não precisa ser tão duro, né? Mas também consigo ler que todo desprendimento é com dor! Por que será, né? Quando as pessoas têm muito apego à matéria, fazer essa transposição, é tudo muito dolorosa." (F7)

Percebendo que a morte do filho está cada dia mais próxima, para a mãe, a sua esperança e o seu consolo estão agora voltados para que este tenha seu sofrimento controlado. Sente-se aliviada e grata por poder constatar que o seu filho continua recebendo cuidados, apesar de estar morrendo e que isto o está mantendo confortável e possibilitará que morra sem sofrimento."

“(...) e eu falei para o doutor que eu vou ser muito agradecida, né?, por tudo que eles fizeram pelo meu filho. Sei que eles tentaram de tudo e agora meu filho está tendo um suporte assim muito 6om. Eles estão muito preocupados para o meu filho não sofrer, não sentir nenhuma dor, para o meu filho ficar confortável. Então, eu estou assim, vendo que ele está sendo bem cuidado, que eu espero que quando ele tiver que partir, que ele parta muito tranquilo, né?" (F8)

A partir desse momento, a mãe precisa dar conta de sua dor, sofre calada porque necessita manter-se firme ao lado do filho até que a morte realmente ocorra. Apesar de sentir que ele já não luta mais ao seu lado, ela tem de sustentar o seu pacto com o filho de estar junto a ele; ela foca seus esforços em aprender a cuidar de um filho que ela já percebe partindo. Nessa luta, crê que precisa ser emocionalmente forte para continuar apoiando e protegendo-o até o final.

“Ai, eu não podia chorar, eu não podia fechar a cara, eu não podia fazer nada! Você está acabada por dentro, mas você não poder demonstrar (...). Sabe?, eu continuei cuidando dela, mas me preparando para partida dela, acho que comecei a preparar para viver sem ela, sabe? Eu comecei cuidar dela assim, sabendo que eu não ia dar mais..., assim, cuidar dela para partida dela. Eu acho que eu fui me preparando para perder ela, sabe?" (F11)

Nesse quadro em que se encontra com o filho, diante de tanta angústia e sofrimento, refere a angústia de pensar que, frente à fase de final de vida da criança, esta possa ser sedada como a única alternativa de conseguir proporcionar-lhe conforto. Muitas vezes, permite a sedação e tenta se convencer de que ela era necessária para o bem-estar do filho. Mas fica com mais um paradoxo, pois sabe que, a partir desse momento, de fato, 
perderá a possibilidade de comunicar-se com ele. Precisar deixar que o filho seja sedado para diminuir seu sofrimento marca definitivamente o fim dessa parceria mãe e filho. Sabe que, a partir desse instante, é um caminho sem volta e o desfecho será inevitavelmente a morte dela. Sofre porque também se dá conta de que o filho sabe que naquele momento estão se despedindo.

"No dia ainda que a doutora colocou ela para dormir, porque a doutora colocou, né?, precisava, a Diana. estava sofrendo demais, ela tinha dor, muita dor (...); ela (médica) veio visitar e ela deu o remédio dela, né? (...) aí ela pôs para dormir, né? Meu Deus! E antes dela dormir, ela despediu de mim porque ela sabia que ela não ia acordar mais, sabe?” (F11)

“(...) ele começou a tomar morfina de seis em seis horas, depois pulou para quatro em quatro horas, depois foi de duas em duas horas. Aí a médica achou que tinha que tomar contínuo, né?, ligado no soro aquele remédio direto. Então, teve que sedar ele no último dia porque ele tinha dor, ele estava muito nervoso, muito, com muita dor, não dormia... Então, teve que sedar ele! (...) Passar aquelas dores..., tudo que ele estava passando... A doutora sedou ele na terça-feira e na quarta de manhã, quando foi quarta à noite, ele faleceu! (...) ele só ficou um dia só sedado, o restante do tempo todo consciente, conversando comigo! Ele falava que amava muito, né?" (F13)

Algumas famílias, ao se darem conta de que a morte da criança é uma realidade e se aproxima, conseguem verbalizar sobre o assunto com os seus outros membros e reconhecem que precisam tomar decisões práticas envolvidas com o processo do pós-morte, como procedimentos de translado de corpo, funeral e buscar informações sobre as medidas que precisarão ser tomadas quando o filho falecer. A mãe assume para ela, também, a responsabilidade para os cuidados com as decisões do pós-morte, como um senso de obrigação para com o filho que está partindo e uma forma de extensão de seus cuidados. Muitas vezes, se vê obrigada a ter de se preocupar sozinha com estas coisas por não encontrar um espaço para debater e compartilhar esse assunto no ambiente familiar, uma vez que, em algumas famílias, o assunto morte segue como um tabu. Conseguir ter claro estes encaminhamentos práticos propicia certo alívio para a mãe de que as decisões referentes a este momento foram acertadas e não tomadas de forma abrupta carregadas pela emoção do momento ou realizadas por terceiros, alheio à sua vontade. 
“(...) eu já pedi, por exemplo, a parte de funeral..., essas coisas... Eu pedi muito reservadamente para um irmão meu, sem alarde, sem que ninguém percebesse que deixasse tudo arrumadinho para mim. Isso aí está tudo encaminhado!" (Choro) "Nós vamos voltar para Cuiabá... Isso de qualquer forma, com qualquer resultado a gente retorna sim! (...) na minha cabeça, por exemplo, a hora que ele partir, quem que eu tenho que chamar, que encaminhamento que eu tenho que dar..., já está tudo na minha cabeça, assim, entendeu? É assim. Eu já tenho tudo assim organizado, não está desorganizado. Já..., já..., já tudo assim organizado. Na minha cabeça, eu já sei o que que eu tenho que fazer, como que eu faço, quem contatar! São medidas necessárias. $\mathcal{N} a$ hora que acontece, eu não sei como a gente fica, né?, nem imagino! Nesse caso assim, por exemplo, eu já separei bem, bem, esses dias que nós saímos para licença-alta tudo, eu já me..., tanto é que a mala está sempre arrumadinha, as coisas estão mais ou menos em ordem, né?, porque tudo isso são providências que têm que ser tomadas, né? O hospital toma com meu consentimento, com meu acompanhamento, só que são coisas que eu que tenho que pensar, porque sou eu que tenho que fazer isso, ninguém pode fazer por mim." (F7)

Apesar de algumas mães demonstrarem preocupação em precisar resolver assuntos práticos relacionados aos encaminhamentos após a morte da criança/adolescente, elas também podem sentir-se incapazes de se preparar e pensar no momento enquanto estão com a presença física da criança. A morte do filho não pode ser admitida e a presença e o contato com o filho reforçam isso, mesmo que a interação com a criança já se encontre diminuída em decorrência do agravo da doença.

“Não sei, não sei como é que vai ser (...). O doutor conversou comigo e falou assim: 'Você está preparada?' Eu falei: Estou me preparando (...), mas eu não sei se eu estou preparada, né? (...), porque eu ainda estou vendo meu filho ali na cama, né? Ele está comigo, não está tendo movimento, não chama mais, assim, nem monossílaba como ele falava, não tem ação nenhuma mais, mas eu ainda estou vendo ele ali, está com vida! E eu não sei como vai ser (...) quando eu... Respondi para o médico que eu estou me preparando. Eu, na verdade, não sei qualé que vai ser minha reação quando eu perceber que o Vinícius. se foi mesmo, eu não sei qual vai ser a minha reação." (F8)

Reconhecer os cuidados paliativos conduz a família a reviver histórias de perdas já vivenciadas no decorrer da trajetória de doença de sua criança, mas a remete a vislumbrar que sua maior perda ainda está por vir e será ocasionada com a morte do filho. Não pode imaginar ainda como isso 
ocorrerá e como poderá suportar um futuro sem ele, mas sabe que terá de encontrar forças, maneiras e recursos de enfrentar mais estes obstáculos.

\section{REAPRENDENDO A VIVER}

A experiência de ter um filho em cuidados paliativos é finalizada com o processo de morrer e consequente morte da criança/adolescente. Esta é uma realidade muito difícil de ser aceita pela família, que busca aprender a lidar com esta nova situação e seguir vivendo, mas jamais aceitando o óbito.

A experiência de ter um filho em cuidados paliativos enquanto vive REAPRENDENDO A VIVER é marcada pela decepção de ter feito todo o tratamento proposto, seguido todas as recomendações da equipe de saúde visando a manutenção da saúde da criança, ter se empenhado incondicionalmente em busca da sua sobrevivência e se ver agora na situação de não ter alcançado o seu objetivo, que é a cura. A família percebe que todo o esforço e sofrimento dispensados até aqui passados tanto pela criança, como pela família durante toda a trajetória da doença não trouxeram o que mereciam.

Durante o processo de ter de se adaptar à vida transformada pela morte do filho - sua maior perda -, a família pode encontrar ou desenvolver condições e estratégias que favorecem uma organização da experiência, viabilizando que encontre um significado que a auxilie no alívio do sofrimento e da angústia. No entanto, algumas delas não conseguem reaprender ou se adaptar à nova vida que a realidade the apresenta, permanecendo, assim, ancorada neste mundo estilhaçado sem encontrar significados e com dificuldade de prosseguir sua vida.

Ao se ver precisando reaprender a viver, a família remonta toda a trajetória da doença vivenciada junto à criança/adolescente até o momento de sua morte, relembrando detalhes da sua experiência. Relembra o papel que a criança/adolescente desempenhava, quando saudável, na unidade familiar e percebe isso como uma de suas maiores perdas. Tanto no aspecto moral, como emocional, ela tenta dar um sentido para a experiência que está vivendo. As perdas sofridas nesse percurso mobilizam sentimentos ambivalentes pelo sofrimento que causaram: dor e saudade pela perda da criança, mágoa e 
frustração por não ter conseguido alterar o rumo da história, gerando sensação de impotência e desamparo. REAPRENDENDO A VIVER é composto pelas seguintes subcategorias: "Recompondo a trajetória da doença", "Aprendendo a lidar com a ausência" e "Não podendo dar significado à perda".

\section{Recompondo a trajetória da doença}

"Recompondo a trajetória da doença" representa a necessidade da família de conseguir encontrar um significado para as experiências vivenciadas, mas especialmente as perdas. Ela encontrar significado para a morte do filho está relacionado às experiências vividas com ela, a família, os profissionais e seu meio social, até mesmo antes da doença. Assim, para a família, é preciso rever sua história de vida e encontrar os significados que podem dar algum sentido para esta trágica experiência.

Diante disso, vai construindo e reconstruindo sua história e procurando indícios do que pode ter aprendido com a experiência, apesar da dor, dessa forma REAPRENDENDO A VIVER. "Recompondo a trajetória da doença" representa a família, sobretudo a mãe, procurando dar um sentido para o seu sofrimento e reconhecendo que a experiência, embora devastadora, é uma oportunidade de crescimento. Percebe sua capacidade de se fortalecer frente às adversidades e à intensidade e cumplicidade da relação mãe-filho nos últimos momentos de vida da criança.

"Eu penso assim, sabe? É que a coisa machucou tanto que as lembranças que eu tenho nesse período é de muito sofrimento dele, esse é o problema, sabe? Apesar que isso aproximou mais a gente, né?, mais do que a gente já era ligado um ao outro, né? Então, acho que isso aproximou mais a gente... assim... Criou um amor assim... mais profundo, né? Entre os três, né? Eu, meu marido e ele (...) Então, eu aproveitei todos os minutos que tinha para ficar perto dele!" (F13)

Ao vivenciar uma situação-limite, como o processo de morte do filho, embora doloroso e angustiante, contribui para que desenvolva ou descubra recursos de enfrentamento que ela desconhecia ou não imaginava possuir. Proporciona-lhe a oportunidade de ser sujeito ativo de sua história e de sair fortalecida por ter tido a possibilidade de se transformar a partir desta experiência. 
"E eu acho que eu me saí bem de tudo isso! Eu estou forte! Eu me saí bem naquela época!" (do falecimento da filha) "Eu consegui lidar bem com a situação (...), eu sou forte mesmo," (risos) "não é que eu estou querendo me gabar não, mas eu sou forte! Olha que não é fácil! Não é fácil! Só Jesus sabe!” (Risos) “Meu Deus, não é fácil, né?” (F12)

"Porque eu que tinha que defender ele, entendeu? Ele depende de mim, eu que tenho que cuidar dele, então (...). Antigamente, eu era uma pessoa muito inibida! (...) está aí uma coisa que meu filho fez diferença na minha vida. Por ele, eu tive que correr atrás e me superar nessa parte, de encarar os outros e frigar pela vida do meu filho (...). Então, é incrível, né?, trouxe coisas 6oas, né?, que só depois que eu vou perceber, né?" (F8)

"E as pessoas que estão em volta" (família de uma criança em cuidados paliativos) "passam..., aprendem alguma coisa... e sempre aprende uma lição de alguma forma, por mais ruim, por mais terrível que seja a situação, você se fortalece de alguma maneira." (F15)

Relembrar momentos vivenciados durante a trajetória de doença faz com que a família, especialmente a mãe, busque novas formas de interagir e se relacionar com os demais familiares. É uma tentativa de aproximar e valorizar relações familiares, desejando que se tornem mais sensíveis às necessidades dos outros e que possam aproveitar os momentos de convívio familiar. Sente-se recompensada também por ter se sentido acolhida pela família na trajetória da doença.

"Eu falo para eles (outros filhos) não brigarem, para eles se amarem, que o dia que eu partir daqui não quero ver briga, não quero que eles sofram, quero que eles cuidem bem dos filhos, que faça o amor, né?, e que tenha amor com os filhos, como eu tive com eles, como eu tenho com eles até hoje, né? (...) porque eu quero falar para eles o que eu estou sentindo, porque o dia que eu sair daqui, eu quero que eles saibam o tudo que eu estou sentindo!" (F13)

“(...) quando a gente tinha aquelas notícias ruins, todo mundo ficava triste junto, né? Então, nós somos uma família! Nós somos uma família! Com certeza, nós éramos uma família, né? Nós somos uma família, que agora só falta um, mas a gente... Nós somos assim. Não está fisicamente... Nós somos uma família unida!" (F15)

Isto significa a experiência de cuidar do filho em cuidados paliativos como uma entrega. A relação/interação mãe-filho é reconstruída a cada dia no decorrer da doença. A certeza de que deu o melhor de si e se entregou 
ao filho durante este período a conforta e lhe permite reaprender a viver em um mundo sem a criança, cujo óbito pode significar para a família um alívio do sofrimento imposto pela doença.

"É... Era... Eu e a Judite era uma coisa tão... Eu e a Judite... que tudo a gente passou tão junto ali, que era eu e ela... Dá para entender? Era o momento meu e dela! Eu não queria dividir ela com ninguém, eu nem lembrava dos meus outros filhos em casa." (NNeste momento, ela eleva pela primeira vez o tom de voz!) "Eu não queria ir para casa, eu não ia para casa e todo mundo: Mas você tem que vir! Eu falava: Mas eu não vou. (...) então, neste momento, continuava sendo eu e ela, eu não queria dividir ela com ninguém (...)" (F12)

“(...) nós vivemos só para Diana., a família toda, sabe? Foi então... Se dependesse de apoio, de carinho, de medicação, ela não teria ido embora." (F11)

"Se eu tivesse que passar por tudo isso de novo, eu passaria e não reclamava! Isso a gente não chama de sacrifício, né?, a gente chama de amor! Mesmo o final não sendo o que a gente espera, o que a gente quer. Isso é amor, porque quem ama faz! A única coisa boa é que agora ele está sem dor (...). Eu fiz o meu melhor. Faria tudo de novo com muito amor! Eu acho que eu fui mãe!" (F13)

O conforto vem por acreditar que conseguiu manter uma parceria com o filho e colaborar para que sua partida fosse de uma forma menos sofrida, por poder acompanhá-lo de perto e falar abertamente sobre a morte. Quando a família revê a experiência e acredita ter feito tudo o que podia pela criança/adolescente ela consegue dar novo significado aos cuidados paliativos e à morte deste seu ente amado.

"Sabe uma coisa que eu fiz muito bem para Dia na, que eu acho que dei muita força para Diana? Foi quando assim... O pessoal morria, eu falava tal pessoa morreu, sempre falava para ela. Alguma criança morria, era amiga dela: Diana, tal pessoa morreu. Sempre falava para ela. Foi uma coisa que deixou ela assim, sabe? Então, ela foi embora sem medo! (...) que ela foi embora muito confiante, aceitou muito bem, sabe? Sem revolta alguma e isso deixou a gente mais confortável." (F11)

REAPRENDER A VIVER é menos sofrido quando a família desfrutou de confiança e de momentos de continência, notadamente com a equipe de saúde que os atendeu. A experiência de ter esta equipe ao seu lado na luta pelo bem-estar da criança/adolescente e de identificar um envolvimento 
emocional da equipe ao vê-la sofrer com a piora do filho proporciona-lhe conforto e segurança de não se sentir abandonada neste difícil processo. É confortante para a mãe perceber que seu filho é querido pelo profissional responsável pelo cuidado para com ele. É a confirmação e garantia que precisa para certificar-se de que a criança/adolescente recebeu cuidado da área de saúde até o momento em que faleceu.

"Vocês" (equipe de saúde) "convivem com criança, se apegam e depois perdem aquela criança. Eu sei que não é fácil para cada uma de vocês aqui dentro. Nossa! A doutora..., ela sofreu muito com a Marília aqui, porque ela foi a primeira a pegar a Marília aqui e quando ela viu a Marília aqui de novo, de novo eu cheguei para ela e falei: Ai! Não acredito! E ela também sofreu comigo, junto comigo, porque elas também se apegam à criança. Isso dá assim... Como que eu vou dizer? Acho que assim..., segurança para a gente, né? Sei lá. Você sabe que tem mais gente com você ali, né?" (F3)

A mãe reconhece que a situação de ter um filho em cuidados paliativos faz com que viva continuamente apreensiva e em constante angústia e pesar. Encontrar um significado para a morte do filho está também baseado em suas crenças religiosas/espirituais e em sua forma de enxergar e interagir com o mundo, em entender esse processo de perda como se estivesse fadada a passar por esta triste experiência.

"Deus recolhe as pessoas muito especiais! Deus acaba recolhendo! Dizem que Deus recolhe porque as pessoas especiais não podem ficar no meio de pessoas que ainda estão evoluindo, que ainda estão crescendo. $\mathcal{E}$ isso me conforta também, sabe? muito. O jeitinho dele, a meiguice dele, a forma como a gente conversa, entendeu? Que a gente soma!" (F7)

“(...) você não pode perder... Eu não perco a fé em Deus! Eu acredito muito nEle! Eu acho que a vida não é só essa, aqui. A gente tem corpo e espírito, o nosso corpinho está aqui e a nossa vida continua em espírito. (...) por alguma maneira, a família está toda reunida, a família tem que passar por isso, a gente vai se fortalecer de alguma forma!" (F1, tia)

Neste sentido, ela empreende um grande esforço em tentar se conformar com a situação, uma vez que passa a se conscientizar de sua impotência em não conseguir alterar os rumos do destino. Ela o coloca em 
poder de uma força superior: Deus. Ele, sim, é responsável pela morte, já que a vida do filho dependia somente dEle. Isto a conforta, porque ela se desculpabiliza. Igualmente, suas crenças religiosas mantêm acesa a possibilidade de poder reencontrar o filho em outra vida.

“(...) a gente tem que manter a força, né? $\mathcal{A}$ força vem lá de cima, né? $\mathcal{E U}$ tenho isso comigo aqui que eu fico assim..., com essa força, mas acreditando que a hora que eu sair daqui eu vou encontrar com ele!" (F13)

“Mas Deus é... Eu só confio naquele lá de cima! Na hora que Ele falar assim: Chega de dor, né?, daí o meu coração vai ficar em paz! (...) mas eu tenho assim um conforto muito grande dentro de mim assim, que nós lutamos juntos, fizemos tudo e a única certeza que tudo que foi... foi segundo a vontade dEle, e isso a gente tem que se render a tudo isso, né filha? e da forma mais prudente e sensata possivel!" (E4)

\section{Aprendendo a lidar com a ausência física}

"Aprendendo a lidar com a ausência física" tem início com a morte da criança/adolescente. O movimento vivenciado pela família durante o curso da doença aponta para a provável perda do filho em virtude da progressão do quadro, do aumento de sintomas, da deterioração física da criança/adolescente e, principalmente, do seu esgotamento emocional, verbalizando sua dificuldade em continuar lutando. A idealização da perda só se realiza mesmo no instante da morte e, talvez, mais especificamente, na ausência física do filho.

Quando a morte é comunicada pela equipe médica, a família se dá conta de que não pode mais ter esperanças pela recuperação. É ela sendo obrigada a abandonar os projetos que incluíam o filho; precisa entender que acabou e que, a partir desse agora, uma ruptura física os separará. Assim, a volta para casa sem ele the é uma experiência extremamente dolorosa. É a concretização de que não existe mais como lutar pela vida dele e de que a separação realmente é um fator inevitável.

"Ele foi no meu braço. Eu tinha que estar lá. Foi o último suspiro que ele deu foi no meu 6raço! Eu falei para a doutora: Faz alguma coisa, pelo amor de Deus! Ela falou: 'Eu não consigo fazer mais nada!' É a pior coisa que se ouve da boca de um médico, quando ele fala que 'eu não 
posso fazer mais nada!' Essa é a pior coisa que você pode ouvir na tua vida!" (Pausa). "Acabou! O pior foi sair de lá sem ele, né? Aquela mala na mão, cheia de roupa, é isso que é duro!" (F13)

“(..) quando ela foi embora, que meu cunhado me levou para casa e eu estava fazendo aquele caminho, eu não me conformava que eu não ia levar ela, que eu não estava levando ela para casa. (...) então, eu imaginava que ela fosse voltar para casa comigo! Eu nunca fiz planos para voltar para casa sem ela! Vai voltar! Com certeza, vai fazer algum tratamento e vai ficar curada, sabe? Os meus planos eram esse, sabe? Eu não pensava em nada mais, o meu foco era nela (...), mas que ela ia melhorar e que eu ia levar minha filha para casa. Era isso que eu imaginava, o contrário eu nunca imaginei!" (F12)

A morte da criança/adolescente modifica para sempre a estrutura familiar, sabe que nunca mais será como antes. O filho não está mais fisicamente presente entre eles, mas as lembranças vividas não podem ser esquecidas ou, simplesmente, apagadas de sua memória, fazendo com que o filho permaneça presente no ambiente familiar. O sofrimento resultante dessa impossibilidade da família se desfazer das lembranças do filho faz com que, para que consiga continuar vivendo, tenha de aprender a lidar com a ausência física da criança.

"Vou vivendo um dia de cada vez, igual nunca mais vai ser, né? $\mathcal{N a ̃ o ~ t e m ~ m a i s . . . ~ M a s ~ u m ~}$ dia de cada vez, aprender a conviver sem ele e não esquecer da presença dele! Agora, eu diria assim, com certeza é sem ele, mas com ele, sabe?" Você se desfaz de um objeto, mas você não desfaz de uma pessoa, você não se desfaz do coração! Eu falo para o meu marido: Objeto é objeto e o CORAÇÃ̃O, TUDO ISSO DAÍ!" (As lembranças do filho) “TÁ AQUI DENTRO!" (Coloca a mão sobre o peito) "Isso é só um objeto. Você não vai jogar o coração fora, se eu pudesse tirar meu coração ou meu pensamento e colocar outra para esquecer isso, tudo bem! Mas a gente não consegue, não é verdade? Não tenho razão? Porque ele está aqui na minha mente, ele está vivo na minha mente e no meu coração também! É só eu fechar os olhos e eu sinto ele perto de mim! Dá impressão que eu sinto ele me abraçando." (F13)

Envolver-se aos poucos com as demandas do cotidiano, retomar suas atividades diárias, como as obrigações da casa e dos outros filhos e a volta ao trabalho, podem ser o impulso necessário para reiniciar sua vida e buscar recursos para reaprender a viver e ir aprendendo a conviver com a ausência física dele. Essas atividades podem significar um importante recurso de 
enfrentamento à família por possibilitar um refúgio ao seu sofrimento. A família vai reaprendendo a viver quando consegue identificar que tem outras potencialidades, mesmo sem a pessoa perdida e lhe da esperança de que é possível sobreviver às adversidades da vida.

"Aprendendo a lidar com a ausência física" envolve o esforço da família em manter seus filhos vivos na lembrança de todos que a rodeiam. É a maneira encontrada de mantê-los presentes. A saudade é um sentimento latente que causa extrema dor. Encontrar uma nova forma de se relacionar com o filho e tê-lo sempre vivo em sua memória e, desse modo, ser possível sentir sua presença é uma das ações que lhe possibilita reaprender a viver.

“Saudade não tem jeito! É o pior sentimento que existe na minha opinião, é o pior! Não tem nada que cure, não tem nada que passe, não tem nada! A única coisa que mata a saudade é a presença da pessoa e é uma coisa que eu não posso ter, nem sonhar com ela eu sonho! E... Mas eu creio nisso, que é... Nós ainda estamos em sintonia, ela só foi primeiro que eu e..., mas ela continua sendo minha filha." (F12)

Ações como conservar o quarto da criança/adolescente como era antes de sua morte, deixar as fotos expostas pela casa, não se desfazer de objetos que the pertenciam e realizar atividades que ela gostava, dentre outras, são maneiras que a família, em especial a mãe, encontra para mantê-la presente na memória.. Por certo, encontra dificuldade em se desfazer de alguns objetos, como brinquedos, roupas e cadernos, dado que estes lhe asseguram que a criança/adolescente ainda faz parte da sua vida e que as lembranças têm de permanecer vivas para que ela siga buscando forças para aprender a lidar com esta ausência.

“(...) meu Deus, o quarto dela está até montado! Eu preciso desmontar o quarto dela, mas eu tenho coragem? Ela tinha tanta coisa com esse quarto! Já dei não sei quantos sacos de brinquedo, mas tem muito brinquedo ainda, sabe?" (Risos) "Eu não consigo desmontar. O pessoal diz que com o tempo eu vou conseguir, com o tempo eu consigo! (...) ela nunca vai morrer dentro de mim, que ela é muito viva! Não, ela é muito viva dentro de mim. Eu converso com as pessoas, que as pessoas perguntam muito dela, sabe? Nossa! Eu converso muito sobre ela! Dentro de mim, ela é muito viva ainda, nada me tira ela! Imagina, meu Deus, ela nunca vai morrer dentro de mim, que ela é muito viva!" (F11) 
"Quando eu não tenho com quem conversar, eu ponho as músicas que ele gostava e fico lembrando dele e chorando!" (Pausa) "Então, é assim. Mas isso faz bem para mim, ver as fotos dele! (F15)

Tenho vídeo dele para ver tudo! Eu preciso manter ele vivo! (...) eu tomando remédio para dormir... É que nem o médico me falou, ele falou: 'Se você toma remédio, você não vai sonhar, o remédio vai te dopar tanto que você não vai nem ter tempo de sonhar'. Então, eu, por força de vontade, eu larguei de tomar os remédios, porque eu quero sonfar, entendeu? Eu quero sonhar! $\mathcal{E}$ o sonho já me feliz, né! É uma forma de ter ele perto de mim!"(F13)

Falar sobre o filho também é uma forma de expressar o quanto ele ainda está presente, mas nem sempre encontra abertura no ambiente familiar e/ou social. A mãe, geralmente, demonstra a necessidade de falar sobre a criança/adolescente, mas percebe que, em muitas situações, é impedida pela família. Caso ela pronuncie algo sobre a criança/adolescente Ihe traz conforto, o que nem sempre acontece para os outros membros da família, que receiam que o sofrimento possa ressurgir ao se permanecer com as conversas. Para a mãe, poder falar sobre o filho a ajuda a seguir firme em seu caminho de reaprender a viver apesar da perda.

"É isso mesmo, eu sinto isso! É... Como eu sinto assim, eu falando dela, eu sinto a presença dela! Às vezes em casa, eles não gostam que fica falando assim tanto como eu falo. $U_{m}$ fala uma coisa, outro fala outra, mas assim, e o assunto encerra, né? Eu não, se me der corda eu vou falando dele assim, sabe?, é dia e noite assim." (F12)

"Eu gosto de falar dele, sabe? E sabe o que eu sinto quando eu falo dele? Eu sinto ele perto de mim, sabe? É isso mesmo que eu sinto!" (F15)

No cotidiano familiar, a presença do filho é marcante e sentida sempre. Sua ausência física ganha destaque nas atividades rotineiras que eram realizadas em conjunto, como refeições e passeios. A dificuldade em se adaptar a esta nova situação é sentida de forma involuntária nas atividades cotidianas e, em algumas situações, pode dificultar que a família prossiga na experiência.

“(...) quando vai viajar assim, o lugar no carro, nos primeiros dias que ela morreu, os quatro pratos na mesa, aí eu: Ai, meu Deus! Quatro pratos? Ela não está aí! Toda hora os quatro 
pratos na mesa, os quatro copos... Então, os primeiros dias foram assim, sabe? A cabeça não aceita. Mas até hoje, de vez em quando, eu ainda coloco os quatro pratos, você esquece e está lá os quatro pratos." (F11)

"Churrasco na minha casa nunca mais foi feito, nunca mais, ninguém se pronuncia mais de fazer um churrasco, ele que era o churrasqueiro!" (F13)

As conversas da mãe e da criança/adolescente, principalmente no leito de morte, não são esquecidas. Ela guarda e interpreta o que the foi dito como pedidos, tendo de ser realizados. Os desejos expressos pelo filho são direcionadores para reaprender a viver sem ele, mas poder mantê-lo no dia a dia.

“(...) mãe, não deixa o pai 6ater nela." (Cachorra de estimação da criança) "Estou indo embora, mas, antes de morrer, não deixa o pai bater nela não, não deixa o pai fazer isso, aquilo outro com ela, você sabe que o pai bate, mãe. E eu falei para ele, sabe?" (risos). "Nunca mais ele deu um tapa nela!" (F11)

"Ela falou assim: 'Mãe a senhora tem que se preocupar com as outras crianças que estão aí, mãe. A senhora não pode sair gritando desse jeito'. Falou: 'Mãe, não sai gritando como essas mulheres aí não que saem gritando, parecem umas loucas berrando aí, assustando as outras crianças'. Ela me pediu muito, sabe? Assim (...) e quando ela morreu, eu não chorei, não consegui chorar." (F11)

"Еu não vou decepcionar ela e ela não vai sofrer porque eu estou sofrendo, porque ela mesma me falou: 'Se você sofrer, eu sofro!' Por isso que eu sigo firme a minha luta aí, tentando ir levando minha vida, fazendo minhas coisas... Acho que é por ela, sabia?" (F12)

\section{Não podendo dar significado à perda}

REAPRENDER A VIVER está composto também por fatores decorrentes da experiência de doença da criança/adolescente e família que dificultam que esta consiga aceitar as perdas vivenciadas. São explicações que ela encontra no decorrer da trajetória e que fazem com que não aceitem que a história termine com a morte do filho.

A família segue atrás de explicações para ter de passar por tantas perdas, mas, sobretudo, por ter perdido o filho. Ela se culpa por algo que possa ter feito de errado no cuidado da criança/adolescente e tem inseguranças 
quanto à sua responsabilidade no encaminhamento do diagnóstico precoce da doença. Imagina que poderia ter sido mais proativa e, consequentemente, teria evitado a morte do filho. Contar e recontar a história várias vezes faz parte da tentativa de seu esforço em encontrar uma explicação para o que aconteceu e busca, com isso, acreditar que ela não é responsável pela morte do filho.

"Eu, como mãe, eu fico com esse pé atrás e também sinto, às vezes, culpada de ter demorado para agir, de ter levado ele no hospital, mas (...). Porque se o tumor tivesse pequenininho ou tivesse grande seria o mesmo processo, foi isso que a médica me falou! Eu sei como esse neuroblastoma é agressivo, ele é muito agressivo!" (F13)

Acreditando que o sistema de saúde falhou pode ser apontado como um dos fatores que dificultam retomar a vida e segui-la em frente sem o filho. Para o familiar, falhas como: demora nos encaminhamentos aos especialistas, erro na opção de tratamento adotada pelos médicos e não se sentir respeitada durante a trajetória podem explicar o fato de o filho não conseguir se curar e morrer. Estes argumentos mantêm na mãe a sensação de que se a doença progrediu a esse ponto de não se conseguir mais detêla é porque faltou algum processo de tomada de decisão por parte da medicina, a equipe de saúde não cumpriu o seu papel de zelar pela vida da criança. Alteram suas crenças e pressupostos com relação à doença e ao seu tratamento pela medicina e se vê descrente de sua capacidade curativa.

"Ela fez a cirurgia e ficou ótima! Só que demorou muito a quimioterapia! (...) que eu achava que ela fez a cirurgia e que não podia demorar tanto para fazer a quimioterapia. Foi uma demora muito grande! Aí, quando você opera, se você já tirou um tumor, a célula corre para o corpo todo não corre? Se tivesse a químio em seguida não teria esse problema. Nisto ele foi espalhando, foi para a cabeça, foi para as pernas, foi para todo o canto." (F11)

“(...) eu sei que a medicina tentou, mas no meu ponto de vista faltou alguma coisa! Que eu acho que quando ele fez a primeira cirurgia, o médico já devia, sei lá, ter tirado mais coisa, né? Sei lá, ter tirado, ter feito transplante de fígado... Aí... Sei lá, faltou alguma coisa! Então, eu acho que o médico deveria ter feito mais alguma coisa no início (...). Eu imaginava assim: que ele ia fazer a cirurgia e ele ia sair dessa, né?, porque eu confiava muito na medicina, né? Hoje, eu já não confio tanto mais, né? SNão confio mais, porque me deixou assim muito... sei lá, descrente!" (F13) 
No decurso da doença, nem sempre a mãe encontra um espaço de continência para expor seus receios, fazer perguntas ou esclarecer dúvidas sobre o estado da criança/adolescente. A consequência disto pode se resultar em uma interpretação da família de que está tudo caminhando bem em relação ao tratamento. Assim, sem um espaço no qual encontre continência, nem sempre a família é proativa no sentido de confirmar suas interpretações em relação ao estado clínico do filho e segue imaginando que ele está sendo tratado. Ao se deparar com a sua morte, questiona o comportamento da equipe em relação ao cuidado prestado.

"Noão, eles" (médicos) "tinham muita ocupação, eles nem tinham tempo de conversar com você (...). Então, eu achava assim, que ele" (médico) "não falava porque ele" (filho) "estava bem! Aí quando foi em 2008 que eu vi que a coisa estava tão grave que não tinha mais retorno, entendeu? Eu penso assim, o médico devia sentar e falar assim: Olha o caso dele é irreversivel, não tem jeito! A gente já fez tudo que podia ter feito, foi feito! Isso só foi dito quando ele estava bem ruim. Eles nunca falaram a verdade assim: Oh, a gente já fez tudo que podia ser feito! Então, eu acho que eles deviam ter... ter me preparado antes. Quando foi dessa última vez, não teve jeito, né? Mas até os médicos já sabiam disso, né? Só eu que não." (F13)

"Quando ele me falou dos cuidados paliativos, eu entendi o que ele me falou, só que eu falei: Nossa! Eu estou cuidando, a gente está tentando tanto, mas ela já está morrendo e ninguém me falou nada?" (F14)

"E eu via minha filha com dor, escutava que ela estava indo embora e (...) para ela" (médica) "aquilo lá é normal, é toda hora aquilo, sabe? É um monte de caso! Então, de cinco em cinco minutos tem esse caso. Nós não, é o único! O nosso caso é único. A gente acha assim, né?, mas para ela não, de cinco e cinco minutos ela tem um caso desse." (F11, pai)

Por outro lado, reconhece que esse mesmo profissional teve sua importância na trajetória da criança/adolescente, pois, mesmo não tendo sido continente, garantiu uma sobrevida da criança/adolescente oferecendo um cuidado apreciado pela família.

“(...) tem médico que é frio! Oh, o remédio é esse aqui. É aquela frieza, né? (...) é o jeito dela." (Médica) "Ela também foi... foi importantíssimo, né? Se não fosse ela e outros lá das Clínicas... nossa!, a Diana. não tinha ficado cinco anos com a gente dando alegria para nós, né, bem? Não tinha, de jeito nenhum!” (F5, pai) 
Os últimos momentos vivenciados junto ao filho ficarão armazenados em sua memória para o resto da vida. Dessa forma, a mãe pode ter 0 sentimento de que seu papel não fora cumprido adequadamente por acreditar que consentiu que o filho morresse sofrendo ou por crer que não foi capaz de proporcionar um diálogo aberto com ele sobre a morte. Dessa forma, a sensação de que algo poderia ter sido feito diferente, notadamente nessa relação de final de vida, faz com que a mãe tenha dificuldade de encontrar um significado para a perda do filho, o que dificulta seguir a vida adiante de um modo mais brando, sem tanto sentimento de culpa.

"Eu acho que meu filho partiu sem me falar alguma coisa. É isso que eu estou sentindo hoje (...). É muito triste você ficar sabendo que a pessoa, que ele estava sabendo e ele não me falou nada e eu estava sabendo que ele ia embora e eu não falei nada para ele! Entendeu como que éo negócio? Eu acho que faltou isso, sabe? De repente, se a gente tivesse se aberto um para o outro, a gente podia ter conversado mais sobre outras coisas. Faltou isso (...)" (F13)

Aceitar a perda de um filho é impossível para a família, que considera a morte injusta e inconsistente, uma vez que, pela lei natural da vida, não deveria acontecer assim, os pais partem antes do que os filhos. Acredita que a criança/adolescente tenha partido precocemente e de que fora tirado seu direito de aproveitar os momentos, sonhos e sua vida com ele. Remonta histórias vividas e compartilhadas durante a vida e projeta histórias que poderiam ser vividas se tivesse o filho ainda ao seu lado. "Não podendo dar significado à perda", a família sente pela interrupção dos sonhos e pelos projetos do filho. Não pode se conformar com a realidade de que ele não poderá realizar seus planos. Nesta circunstância, ela não encontra explicação para a morte, mas, principalmente, nem sentido em seguir a vida adiante sem o filho.

"Muito duro você perder um filho nessa idade e nessa situação. Todo o sofrimento que a gente teve aqui, se ele tivesse ficado 6om (...), nada disso a gente estava lembrando mais. A gente sofreu tanto! Foi muito difícil! (...) eu achava que tudo aquilo que eu tinha feito estava indo de água abaixo! Mas foi um sacrifício de ele passar por tudo que ele passou e quando chegar naquela hora, ele me deixar." (F15) 
“.... eu daria minha vida para ter minha filha de volta, para ela ficar aqui, para ela fazer alguma..., para ela fazer o que ele queria fazer aqui! Porque ela não pôde fazer o que ela queria. Se eu pudesse trocar a minha vida por ela, eu trocava, nossa num segundo, sem pensar, falava: Vem, fica aí Diana, vive tua vida que eu estou junto! Mas não tem como!" (F11)

Algumas famílias não conseguem reaprender a viver em um mundo transformado pela morte do filho. A vida já não tem mais sentido e sente imensa dor que a engessa e a impede de seguir seu cotidiano, permanecendo rígida na crença de que não é possível seguir a vida sem desempenhar o papel de mãe da maneira como o fazia antes da morte do filho. Ela ainda necessita encontrar significados que a ajudem a superar o sofrimento e reaprender a viver.

"E o que eu espero daqui para frente? $\mathcal{N} A D A$ ! Então, eu acho assim, o que eu tinha que fazer eu já fiz! Eu não vou construir mais nada. (...) eu não tenho mais nada aqui! (...) eu perdi assim o gosto de viver! Eu vivo assim por eles (família), não fico demonstrando que eu estou triste, mas eu, lá dentro de mim, eu tenho uma tristeza assim que quando eu engulo a saliva dói meu peito! Mas eu não quero mostrar isso para eles e eu falo para o meu marido: Olha, eu quero ir primeiro do que você, porque eu não quero sofrer mais." (F13)

\subsection{Contando a História}

As categorias apresentadas permitiram compreender a experiência da família quando vive o processo de ter um filho em cuidados paliativos. A análise destas categorias e de suas subcategorias e da maneira como interagem na experiência da família permitiu identificar o processo representado pela categoria central FLUTUANDO ENTRE A ESPERANÇA E A DESESPERANÇA EM UM MUNDO TRANSFORMADO PELAS PERDAS. Esta categoria foi identificada a partir do desejo persistente das famílias de fazer o melhor para seu filho e mantê-lo com o pensamento positivo em um contexto constantemente permeado por perdas. Nesse processo, as famílias precisam controlar a doença, a fim de prolongar a vida da criança/adolescente e mantê-la viva; a esperança é o que as mantém firme neste propósito. A integração entre as categorias e sua articulação com a categoria central viabilizou a construção 
de um modelo teórico, que representa a experiência da família ao vivenciar o cuidado de um filho em cuidados paliativos.

A experiência começa com a família TENDO A VIDA ESTILHAÇADA caracterizada pela notícia dada pelo médico de que a criança/adolescente está em cuidados paliativos. Esta nova informação de que o filho não poderá mais ser curado, mas que receberá cuidados para controlar os sintomas e, com isso, tentar retardar a progressão da doença não é facilmente compreendida e aceita pela família. "Tendo o filho em cuidados paliativos" expõe a família a uma nova realidade: a de que o tratamento medicamentoso existente não é suficiente para impedir ou controlar o avanço da doença. Surpresa com a nova condição apresentada pela equipe, ela fica preocupada com o prognóstico e amedrontada com o possível sofrimento físico da criança/adolescente A notícia de que o filho está em cuidados paliativos é a causa deste processo acerca do significado de ter um filho nestas condições, ou seja, sem possibilidade de cura. O desconhecimento do que causou a mudança de status da criança/adolescente - estar em tratamento de uma doença crônica para uma outra que não existe mais tratamento - faz com que a família se perceba sem recursos para entender o que levou à mudança de conduta da equipe e passa a viver a experiência tentando entender esta nova condição.

A família, por estar vivenciando uma longa trajetória da doença, já enfrentou muitas adversidades e crises junto ao filho, necessitando de vários tipos de intervenções e internações para suporte clínico e início de nova terapia quando se viu, no caso das doenças oncológicas, frente ao reaparecimento da doença. Ter vivenciado estes momentos com êxito dos esforços empreendidos conjuntamente - criança/adolescente, família e médicos - no decorrer da caminhada faz com que a família se mantenha acreditando que suas práticas para o cuidado da criança/adolescente os levará à nova recuperação e à vitória do filho frente ao avanço da doença.

"Tendo o filho em cuidados paliativos" em casa e conseguindo manter uma rotina familiar sem muitas alterações do que já viviam com a criança/adolescente doente, a família, neste momento, ainda não pode aceitar a nova condição do filho de que a doença não tem controle e que progredirá em tempo indeterminado. 
“Não podendo aceitar a nova condição" representa a família ainda sob o impacto da notícia de ter um filho em cuidados paliativos; ela não pode aceitar a realidade da doença sem cura e vive com a esperança de que a criança ainda viverá por um longo tempo, nem admitir que depois de ter enfrentado uma longa jornada de tratamento marcada por tanto sacrifício e sofrimento não receberá o lucro deste investimento: ver o filho curado.

Portanto, "Tendo o filho em cuidados paliativos" e "Mantendo a criança/adolescente em casa", conseguindo cumprir, na maior parte do tempo, o seu cotidiano com o filho doente, a família vive o presente, dia a dia, e age "precisando manter a criança/adolescente viva". A família FLUTUANDO ENTRE A ESPERANÇA E A DESESPERANÇA EM UM MUNDO TRANSFORMADO PELAS PERDAS ainda não pode imaginar a perda do filho, pois esta é incoerente e injusta diante do que já passou. Para ela, é como se a equipe a estivesse abandonado e dando a batalha como perdida e ela ainda não podia aceitar esta realidade. Por acreditar que a equipe de saúde enganara-se sobre prognóstico tão sombrio do filho, sustenta a esperança em sua recuperação e se conserva proativa em buscar recursos que mantenha o rumo da história da maneira como imaginara após "a cura" da doença. Por isso, questiona a equipe sobre novas formas de tratamento para o filho como uma maneira de "manter a criança viva" e, de preferência, em casa, evitando as internações.

A família exprime e se comporta do modo como define a situação para si. Neste ponto, ainda não pode aceitar a gravidade do quadro que se abre à sua frente, o que reflete sua dificuldade em internalizar a condição da doença. Então, o foco é preservar a vida do filho, que é uma ação mobilizada pela indicação da família em direção ao seu self e, com isso, geralmente a mãe, vendo-se apenas como mãe, assume o comando da batalha para preservar a vida da criança/adolescente, determinada a não desistir da luta.

"Mantendo a criança/adolescente em casa", a família vai MANEJANDO A NOVA CONDIÇÃO clínica da criança/adolescente. MANEJANDO A NOVA CONDIÇÃO representa as ações e estratégias desenvolvidas pela família da criança/adolescente em cuidados paliativos, 
com o intuito de alcançar um equilíbrio entre atender as demandas da doença e a preservação da rotina familiar. A esperança é algo que afasta 0 medo de perder o filho e mantém a família no foco de cuidar da criança/adolescente oferecendo-Ihe a melhor qualidade de vida possível no controle dos sintomas. FLUTUANDO ENTRE A ESPERANÇA E A DESESPERANÇA EM UM MUNDO TRANSFORMADO PELAS PERDAS, a família tem um papel ativo durante toda a trajetória da doença e, ao precisar encontrar meios para aprender a manejar a nova condição na qual reitera seu papel e sua responsabilidade de cuidar do filho, não poupa esforços.

MANEJANDO A NOVA CONDIÇÃO mantendo a esperança na cura ou no controle e retardo da progressão da doença, a família age com o firme propósito de preservar o filho confortável, com a doença controlada e, preferencialmente, em casa. "Mantendo a criança/adolescente em casa" assim, ela consegue ir preservando a qualidade de vida de toda a família, sua estrutura familiar e, com isso, conservando o cotidiano da família o mais próximo da normalidade. No entanto, durante esta trajetória, a família e suas crianças/adolescentes em cuidados paliativos são acometidas por múltiplas e sucessivas perdas que podem atingir as esferas física, emocional, afetiva, social e financeira.

"Vivenciando perdas" é um dos componentes do processo que aproxima a família da nova realidade e da possibilidade de morte da criança/adolescente. A família sofre ao ir "vivenciando perdas", porque o filho vem apresentando limitações progressivas e assim, ela sente que está perdendo o controle sobre a doença. Nesta condição, MANEJANDO A NOVA CONDIÇÃO e "precisando de suporte", busca ajuda no grupo de cuidados paliativos ou nas internações da criança/adolescente, que passam a ser cada vez mais frequentes.

FLUTUANDO ENTRE A ESPERANÇA E A DESESPERANÇA EM UM MUNDO TRANSFORMADO PELAS PERDAS, o suporte social recebido pela família influencia na maneira de lidar e enfrentar as adversidades decorrentes do avanço da doença. Os significados surgem a partir das interações vividas por ela, entre os familiares, com a própria criança/adolescente, com a equipe de saúde e com o meio. Ser reconhecida e apoiada faz com que a família sinta-se 
emponderada e esperançosa para seguir adiante em sua luta pela manutenção da vida do filho. Por outro lado, ao não encontrar espaços de continência, especialmente por parte da equipe, sente-se sobrecarregada e, sobretudo, solitária em sua batalha pela vida do filho. A mãe acredita que precisa manter o seu papel de mãe forte e cuidadora e que, para isto, não deve demonstrar seus sentimentos, medos e angústias, porque estes podem fragilizar a criança/adolescente e o restante da família. Por isso, sofre calada e procura se mostrar sempre forte, notadamente na frente do filho, ainda que esteja estilhaçada pela dor da possibilidade de perdê-lo.

O conjunto da experiência evidencia os fatores que podem ajudar ou inibir a família a ir RECONHECENDO OS CUIDADOS PALIATIVOS. Ao vivenciar as internações ou as visitas ao grupo de cuidados paliativos, a família percebe que o filho também se beneficia de algumas intervenções da equipe de saúde, como medicamentos e fisioterapia, os quais aliviam o seu desconforto físico. Assim, passa a dar um novo sentido aos cuidados paliativos, começa a reconhecê-lo como uma oportunidade de aliviar o sofrimento da criança.

Faz parte do processo FLUTUANDO ENTRE A ESPERANÇA E A DESESPERANÇA EM UM MUNDO TRANSFORMADO PELAS PERDAS, ainda em um contexto de sofrimento que está continuamente presente enquanto a família vai MANEJANDO A NOVA CONDIÇÃO, uma parceria incondicional entre a criança e a família, mas, em especial, a mãe. Sabe-se que o empenho deve ser de toda a família e juntos "engajam-se nos cuidados". É com esta determinação e empenho, geralmente liderados pela mãe, que se mantém a esperança de atingir com êxito a recuperação. A família entende que não pode permitir que a criança/adolescente se entregue à doença e desista dessa luta. Para tanto, engaja-se em motivá-la a ser forte, a manter um foco positivo e resistir às lutas diárias que lhe são impostas. Reconhecem a coragem da criança/adolescente, no entanto, em sua interação com o filho, percebe o quanto é doloroso para ele também se ver naquela situação, ciente de suas limitações físicas, perdendo sua independência, por vezes até a capacidade de se verbalizar. Percebe que o filho se angustia e sofre "vivenciando perdas" e limitações que o distanciam da vida social. 
Com a progressão da doença, a família reconhece que perde o controle sobre os sintomas apresentados pela criança/adolescente e também que está perdendo seu controle de ir MANEJANDO A NOVA CONDIÇÃO. As alterações com a saúde do filho acontecem de forma cada dia mais acelerada. A criança/adolescente vai "desaparecendo" aos poucos diante dos olhos da família, fazendo com que ela, ainda que FLUTUANDO ENTRE A ESPERANÇA E A DESESPERANÇA EM UM MUNDO TRANSFORMADO PELAS PERDAS, comece a conviver com a possibilidade real da perda $e$ ir RECONHECENDO OS CUIDADOS PALIATIVOS.

Assim, FLUTUANDO ENTRE A ESPERANÇA E A DESESPERANÇA EM UM MUNDO TRANSFORMADO PELAS PERDAS, a família vai RECONHECENDO OS CUIDADOS PALIATIVOS, que é a contingência do processo no qual ela vive a incerteza entre a possibilidade de cura ou a morte da criança/adolescente. Conscientizar-se que a doença progride, a nova meta, então, deve ser a qualidade de vida e o controle de sintomas físicos ocasionados por esta progressão e desordens emocionais consequentes deste processo. Isto permite-lhe seguir em frente com menos sofrimento. Todavia, esta é uma tarefa árdua, tendo em vista que a família se deparará com a sua raiva, ansiedade e medo em relação ao futuro. Quando a família não encontra pessoas que a ajudem a gerir estes sentimentos, pode ser impossível RECONHECER OS CUIDADOS PALIATIVOS.

RECONHECENDO OS CUIDADOS PALIATIVOS exige que a família vivencie a transição entre ter o filho vivo e curado para ter um filho com os sintomas controlados ou não. Ao reconhecer os cuidados paliativos, a família enfrenta incertezas, angústia e pesar, pois passa a conviver com a possibilidade da morte iminente do filho. A incerteza consideravelmente presente neste processo dificulta definir a legitimidade da posição médica de que a criança/adolescente se encontra em cuidados paliativos. Ainda assim, a família não se intimida frente a esta nova realidade dos cuidados paliativos, porque acredita que este é o único caminho que a conduz a permanecer junto ao filho por mais algum tempo. 
A possibilidade de morte do filho é perturbadora para toda a família e dificulta a visão do futuro sem a criança/adolescente; por esta razão é que o seu foco está sempre voltado para o presente. Ela aprende que pensar no futuro sem o filho é dispensar a energia de que eles precisam, por isso, FLUTUANDO ENTRE A ESPERANÇA E A DESESPERANÇA EM UM MUNDO TRANSFORMADO PELAS PERDAS vão "aprendendo a viver um dia de cada vez".

Compreender as mudanças nas condições clínicas da criança/adolescente e ir RECONHECENDO OS CUIDADOS PALIATIVOS e, consequentemente, a possibilidade de morte iminente do filho é determinada pela experiência marcante de que estão "perdendo a parceria com o filho". Esta é quase uma condição que determina a possibilidade da família em considerar a impossibilidade de cura e a aceitação da morte. Ao constatar que o filho está lúcido e consciente de sua condição clínica descontrolada, vivenciando sua deterioração progressiva a cada dia, ela sofre também pelo sofrimento da criança.

A criança é ativa neste processo de ir FLUTUANDO ENTRE $A$ ESPERANÇA E A DESESPERANÇA EM UM MUNDO TRANSFORMADO PELAS PERDAS. Ela participa ativamente da luta em busca do tratamento e do seu bem-estar até o momento que se percebe esgotada física e emocionalmente e é capaz de expressar seus sentimentos e desejos para a família, quando encontra espaço. A mãe se vê "perdendo a parceria com o filho" quando ele, com coragem, expressa seu desejo de parar de lutar, de descansar e de morrer. Deparar-se com estes sofrimentos físico e emocional percebidos pela sua falta de vontade de viver, de forças e desesperança, a mãe conclui que sua parceria com o filho chegou ao fim.

FLUTUANDO ENTRE A ESPERANÇA E A DESESPERANÇA EM UM MUNDO TRANSFORMADO PELAS PERDAS, a mãe vive a ambivalência entre o desejo de interromper a continuidade do sofrimento do filho e o de evitar sua morte a qualquer custo, mas sente a desesperança dele pela vida e reconhece que, nesse momento, independente de seus esforços, é incapaz de reverter o quadro e tirá-lo dessa situação, o que a leva sentir-se impotente e angustiada; 
conscientiza-se também do cansaço e de que lhe estão faltando forças para poder suportar e testemunhar este sofrimento atroz.

Faz parte desse contexto de sofrimento continuamente presente enquanto a família vai vivendo o processo de morte - a dificuldade de ela falar sobre a iminência da morte. Se, por um lado, procura um espaço de continência para repor suas energias e seguir lutando junto, por outro, conversar sobre isto não é aceito para muitas delas. Verbalizar esta morte significa a sua completa desesperança e derrota total. Alguns familiares creem que discursar sobre o assunto em pauta provoca sofrimento a todos, por isso optam por fazer o pacto do silêncio.

A sua dor está agora relacionada ao tempo que ainda poderá contar com a presença do filho. Vive com as incertezas decorrentes da possibilidade da perda diariamente até que esta efetivamente se concretize. Assim, o processo FLUTUANDO ENTRE A ESPERANÇA E A DESESPERANÇA EM UM MUNDO TRANSFORMADO PELAS PERDAS vivenciado pela família que tem um filho em cuidados paliativos tem como consequência a morte da criança/adolescente e a família precisando REAPRENDENDO A VIVER, sem a presença física da criança/adolescente. Esta é uma realidade muito difícil de ser enfrentada pela família, que busca aprender a lidar com esta nova situação e seguir vivendo, mas jamais aceita a morte. FLUTUANDO ENTRE A ESPERANÇA E A DESESPERANÇA EM UM MUNDO TRANSFORMADO PELAS PERDAS exige que ela se adapte à vida transformada pela sua maior perda: a morte do filho.

A família pode encontrar ou desenvolver condições e estratégias que favorecem uma organização da experiência, permitindo que encontre um significado que a auxilie no alívio do sofrimento e da angústia e lhe facilite ir REAPRENDENDO A VIVER sem a presença física da criança ou permanecerem engessados em um mundo estilhaçado pelas perdas, "não podendo dar significado à perda". REAPRENDENDO A VIVER é menos sofrido quando a família desfrutou de confiança e de momentos de continência, especialmente com a equipe de saúde que os atendeu. Nesta condição, encontra significados para a experiência vivida, vai "aprendendo a 
lidar com a ausência física" do filho e aprende novas maneiras de mantê-lo vivo no seio familiar.

Então, pode-se dizer que o processo FLUTUANDO ENTRE A ESPERANÇA E A DESESPERANÇA EM UM MUNDO TRANSFORMADO PELAS PERDAS representa a experiência da família que tem um filho em cuidados paliativos. O processo indica a experiência vivida por ela, que está consciente de querer proporcionar a melhor vida que ainda resta para o filho e para a unidade familiar antes e depois da sua morte.

FLUTUANDO ENTRE A ESPERANÇA E A DESESPERANÇA EM UM MUNDO TRANSFORMADO PELAS PERDAS representa o processo vivido pela família na busca por uma trajetória que garanta a melhor vida para a criança/adolescente com a integração dos cuidados paliativos em suas vidas, alcançada por meio de transformação de valores na sua filosofia de vida e influência das interações sociais vividas durante o processo.

O modelo teórico FLUTUANDO ENTRE A ESPERANÇA E A DESESPERANÇA EM UM MUNDO TRANSFORMADO PELAS PERDAS é representado pela Figura 1. 


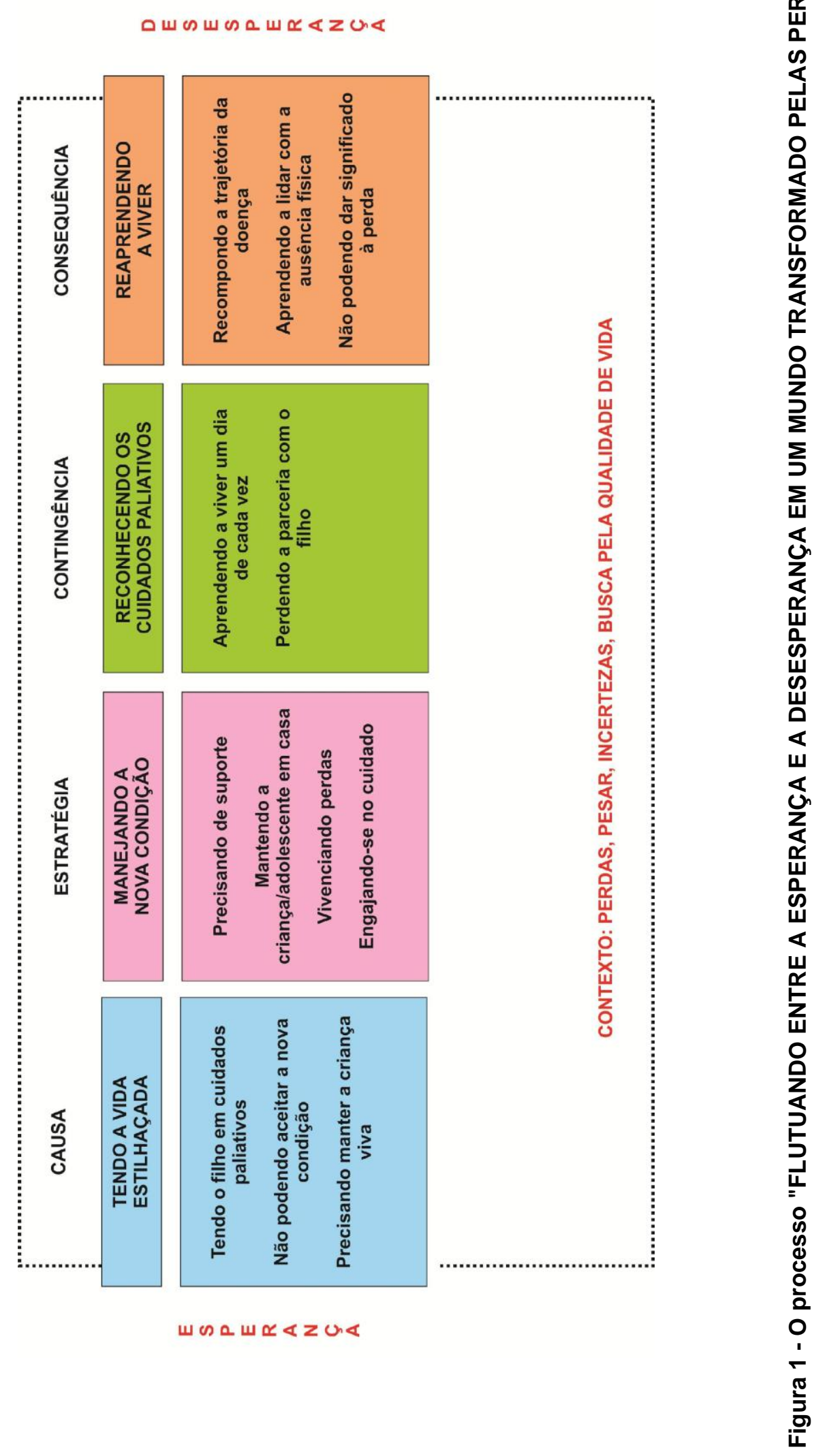


5 Discussão 
Nesse estudo apresenta-se uma teoria substantiva que oferece uma explicação sobre o processo FLUTUANDO ENTRE A ESPERANÇA E A DESESPERANÇA EM UM MUNDO TRANSFORMADO PELAS PERDAS, que representa as ações e interações empreendidas pela família consciente de querer oferecer a melhor vida para o filho e para a unidade familiar antes e depois da morte da criança. O processo é constituído por quatro subprocessos que, continuamente, se inter-relacionam ao longo da experiência da família e consistem em desafios para os quais ela precisa empreender ações e estratégias, a fim de superá-los. Por estar limitada a uma situação e contexto específico, a teoria é denominada substancial (Strauss e Corbin, 2008).

Condições que limitam ou ameaçam a vida da criança causam alterações nos padrões de interação da família, requerem uma reorganização familiar e a colocam em face das mudanças adaptativas que podem impactar seu funcionamento, desencadeando alterações significativas em toda a sua estrutura (Knapp et al., 2010).

Receber a notícia de que a doença do filho não tem possibilidade de cura e/ou que os tratamentos existentes até o momento não são mais efetivos para manter o controle sobre sua progressão é um choque para a família e a coloca frente à possibilidade de não ver seus sonhos e projetos com o filho concretizados e com a realidade de sua morte. $\mathrm{O}$ desejo e a expectativa da família são conseguir curar sua criança, o que nem sempre Ihe é possível; mas frente à realidade de ter um filho em cuidados paliativos, ela precisa aliar forças para lutar com a finalidade de impedir sua morte.

Durante a fase curativa, pais e equipe médica trabalham lado a lado pela sobrevivencia da criança (Hutton et al., 2006; Kars et al., 2011). A mensagem de que o tratamento falhou ou que este já não consegue mais manter estabilizada a doença confronta os pais com a inevitabilidade da 
perda de sua criança. Percebem sua vida perdendo o sentido com a probabilidade da sua morte e o sentimento dominante, evidentemente, é que não podem deixá-lo partir (Kars et al., 2011; Bousso et al., 2012).

Assim, a experiência da família da criança/adolescente em cuidados paliativos demonstra que ela está vivendo os desafios físicos e emocionais de ter de conviver com a sentença de um filho em cuidados paliativos e a busca incessante por manter equilibrada a vida familiar e a qualidade de vida.

Os dados deste estudo permitem inferir que, para a família, o período de cuidados paliativos é marcado por sentimentos de incerteza, apreensão, mas, acima de tudo, é um período de adaptação a uma nova maneira de viver a vida. Este processo envolve adaptações aos sintomas físicos da criança, aos novos papéis que os membros familiares passam a desempenhar em função da condição da criança e aos ajustes no tempo que serão destinados às tarefas recentes que envolvem o seu cuidado.

Essa situação inovadora pela qual passam e a visão que a família tem sobre a condição e o prognóstico da criança refletem na qualidade de vida de ambos e nas estratégias que a família utilizará a partir deste momento para manejar e enfrentar esta condição.

Estratégias e ações vão sendo necessárias para que a família consiga readaptar-se a esta outra vida, onde deve aprender a lidar com as perdas que estão presentes em todo o percurso da doença e dos cuidados paliativos e também o luto decorrente dela; ao mesmo tempo, têm de manter a esperança de conseguir manter o filho vivo. Assim, a família da criança/adolescente em cuidados paliativos vivencia o sentimento de perda no decorrer da doença e não apenas após sua morte, o que precisa ser reconhecido pelo profissional que lhes presta atendimento.

A literatura aponta que, para a família da criança, a certeza da perda e o luto iniciam-se quando que lhe é dado um prognóstico que pode limitar a vida do filho; isto porque, mesmo que estejam vendo e tenham a criança viva ao seu lado, ainda ativa, já começam a conceber que o futuro com sua presença pode estar por um tempo limitado. Mesmo que tentem afastar-se desta realidade, o fato os assombra a todo o momento (Kars et al., 2011; 
Price et al., 2011; Titus, Souza, 2011). Este período é definido pela família como um caos instaurado em sua vida e relata seguir seus dias desorientada e desconcertada, sem saber, ao certo, o que fazer, o que pensar, como agir e alternando sentimentos de medo e esperança. A partir de então, a vida torna-se um "período incerto de espera", apreensiva e permeada pelo medo de que a criança faleça (Titus, Souza, 2011).

Rolland (1998) afirma que a "[...] antecipação da perda devido a uma doença física pode ser tão perturbadora e dolorosa para as famílias quanto a morte efetiva de um de seus membros [...]" (p. 166). Nesse processo pelo qual as famílias antecipam perdas futuras e convivem com sua ameaça por um tempo indeterminado ao longo do desenvolvimento da doença, experienciam uma gama de sentimentos que trazem consequências para todas as dimensões da vida familiar com o decorrer do tempo. Ela carece enfrentar os desafios de conviver com a incerteza diante da tragédia, a ocorrência da morte e, ao mesmo tempo, tem de manter a esperança, devendo receber por parte dos profissionais uma abordagem que permita 0 entrelaçamento dos esforços familiares para que the seja possível manter a esperança, enfrentar graus variáveis de incerteza e se preparar para a perda com a progressão da doença. Dessa maneira, auxiliar as famílias a conseguirem estabelecer padrões funcionais o mais precocemente possível possibilita-Ihe o enfrentamento e a adaptação posteriores à perda (Rolland, 1998).

Contudo, ao receber a notícia de que o filho está em cuidados paliativos, a família deve continuar vivendo e não pode aceitar que nada mais pode ser feito para se alcançar a cura do filho. Assim sendo, não pode se entregar e necessita mostrar-se firme em seu propósito de tentar resguardar a vida do filho, apesar das adversidades encontradas com a trajetória dos cuidados paliativos. Neste particular, deparam-se com as perdas diárias decorrentes da evolução e progressão de forma assustadora da enfermidade.

As doenças degenerativas são responsáveis por perdas em diversos âmbitos da vida no processo evolutivo. Além das perdas físicas específicas de cada enfermidade, também são vivenciadas as perdas afetivas, sociais e 
financeiras, que podem produzir sofrimento psicológico a pacientes, familiares e cuidadores. Essas sucessivas perdas levam a família a reestruturar frequentemente sua vida, por meio da elaboração de perdas de partes de si e do outro, em função das limitações que se intensificam (Salgueiro, 2008).

As perdas decorrentes de doenças ou acidentes são descritas como uma forma de morte simbólica, pois constituem a morte de partes de si como pessoa ativa, profissional, genitor e parceiro, vivida de maneira consciente. A perda do outro é caracterizada pela perda e separação dos familiares, pessoas do entorno social e queridas, trazendo profundas modificações em suas vidas, as quais recebem influência de variados fatores, como grau de energia investida em determinada atividade ou função que não pode mais ser realizada, severidade e estabilidade da limitação, fase de desenvolvimento do sujeito, características de personalidade, experiências vivenciadas e possibilidades de enfrentamento (Kovács, 1999).

No presente estudo, a família reconhece que não conseguirá continuar vivendo como antes. A partir de agora, agem levando em consideração o efeito dos seus atos na qualidade de vida do filho e, para ela, manter a criança assintomática ou com o mínimo de sintomas em casa, definitivamente, é o que propicia melhor qualidade de vida. Portanto, nesse sentido, a sua qualidade de vida aparece diretamente relacionada ao bemestar do filho.

Conseguir manter o controle dos sintomas da doença do filho traz um senso de normalidade, na medida em que consegue manter a vida o mais próximo possível do que era antes da chegada da doença. Tal fato é apontado pelos familiares como um fator importante para a decisão de manter os cuidados domiciliares o máximo possível e sempre que a situação da criança assim o exigir. Poder mantê-la no ambiente domiciliar proporciona-lhe maior sensação de liberdade, assim como também com relação à própria família para cuidar e se relacionar com o filho e, consequentemente, menor alteração em sua dinâmica.

Nosso estudo é consistente com a literatura, segundo a qual se empenhar em tentar manter as atividades das famílias regularmente e o 
mais próximo do que vivenciavam antes, no contexto dos cuidados paliativos, é o máximo que lhes é permitido fazer, persistindo, assim, continuarem vivendo e tentarem manter sua unidade familiar em meio à ruptura e ao caos já instaurados (Monterosso et al., 2009; Price et al., 2011; Titus e Souza, 2011). Além do mais, reflete a importância para a família de fazer com que a criança continue vivendo, apesar das dificuldades e limitações por ela enfrentadas com a progressão da enfermidade (Menezes, 2010; Zelcer et al., 2010).

No entanto, esta decisão tem como consequência o temor do aparecimento de sintomas e da falta de habilidade para manejá-los, bem como a preocupação de estarem oferecendo o melhor para a criança para o resto da família. A opção por deixá-la no domicílio esbarra também na preocupação com o tipo de suporte que receberia da equipe de saúde caso resolvessem deixá-la sob cuidados na residência e a dificuldade e o medo de não se conseguirem manejar caso houvesse aparecimento de mais sintomas (Zelcer et al., 2010; Bousso et al., 2012).

Acima de tudo, este trabalho permite afirmar que, para estas famílias, poder permanecer com o filho em casa foi o que configurou e manteve sua esperança de continuar sonhando com a recuperação e manutenção da vida da criança; mas, acima de tudo, é o que afasta, ainda que temporariamente, a possibilidade da morte do filho do contexto da família.

Dessa maneira, em momentos de crise, elas têm de restabelecer a crença de que possuem algum controle sobre a situação. Para isso, os profissionais de saúde precisam auxiliá-las no sentido de prover informações sobre os sintomas significativos e a doença, priorizar tarefas e realizar ações, como ajudar a reunir recursos da comunidade (Rolland, 1998). As respostas familiares frente às situações de ameaça à vida são decorrentes de seu sistema de crenças. A maneira como as pessoas agem diante da ameaça da perda está influenciada pelo sentido atribuído à incapacitação, à morte e também por sua competência em influir no desenrolar dos eventos (Rolland 1998).

Assim, a família começa a encontrar meios de manejar a nova condição que se abre à sua frente, os cuidados paliativos do filho. Nessa 
jornada, o suporte social recebido por ela influencia na maneira de lidar e enfrentar as adversidades decorrentes do avanço da doença. Os significados surgem a partir das interações vividas pela família entre os seus membros, com a própria criança, com a equipe de saúde e com o meio. Sentir-se reconhecido e apoiado faz com que a família sinta-se emponderada e esperançosa para seguir adiante em sua luta, qual seja, salvar a vida do filho. Por outro lado, ao não encontrar espaços de continência, principalmente por parte da equipe, faz com que se perceba sobrecarregada e, especialmente, solitária nesta árdua batalha pela vida do filho.

Outrossim, a esperança, perseverança e as crenças espirituais são fatores que a orientam e a encorajam para continuar lutando pela vida do filho em um contexto de incertezas, angústia e sofrimento. Ao longo da caminhada, a família integra os cuidados paliativos em suas vidas e redefine valores com o auxílio das interações sociais vividas durante o processo.

A experiência da família da criança/adolescente em cuidados paliativos vem permeada pela esperança. Em nosso estudo, ela coloca a esperança na cura da criança, na possibilidade de mantê-la viva por mais tempo, na esperança de um milagre que a salve da morte e com total esperança de que o filho não sofra e que possa mantê-lo confortável e com qualidade de vida, ainda que a cura não seja mais uma realidade viabilizada.

Apesar da dificuldade de se obter um consenso sobre a definição de esperança, a maioria a retrata como um estado relacionado a uma perspectiva positiva quanto ao futuro (Kylmä et al., 2009), o que permite a expectativa de alcançar um objetivo, algo necessário para a vida (Stotland, 1969). Desse modo, é um fenômeno complexo, dinâmico e multidimensional que pode ser influenciado por uma série de fatores, incluindo profissionais de saúde (Duggleby et al., 2010).

Sob este aspecto, em nosso estudo, é esta expectativa da família em alcançar seu objetivo - que é a cura do filho ou retardar a progressão da doença o máximo possível, tentando diminuir seu sofrimento e melhorando sua qualidade de vida - que a mantém firme em seu propósito de seguir cuidando dele e buscando recursos que a possibilite alcançar a vitória de sua luta. 
Assim, nosso estudo é consistente com a literatura, onde a esperança vem sendo identificada como um conceito central tanto para quem está doente como para as pessoas que a cercam e é vital para a maneira como as pessoas experienciam e respondem a uma doença grave, constituindo um recurso humano que vem sendo utilizado como estratégia de enfrentamento por pessoas com diferentes doenças (McClement e Chochinov, 2008; Sutherland, 2009; Duggleby et al., 2010; Berendes et al., 2010). No contexto dos cuidados paliativos, a importância da esperança como uma experiência positiva para pacientes e familiares tem sido discutida na literatura (Holtslander, 2008) e aparece como fundamental na forma como pacientes e familiares viverão os períodos de final de vida. Sob esta óptica, estabelecer metas e objetivos reais com a pessoa doente constitui uma das formas de restaurar e manter sua esperança (Twycross, 2003).

Estudo que realizou uma revisão integrativa da literatura com o propósito de verificar o conhecimento que vem sendo produzido sobre a esperança na área de cuidados paliativos revelou que ainda grande parte deles versa sobre a questão da esperança no paciente adulto e que poucos trabalhos têm sido feitos envolvendo a esperança, o paciente pediátrico e a família. Ao se considerar a variedade de doenças para as quais o cuidado paliativo poderia ser implementado, o câncer ainda ganha destaque nas pesquisas que a envolve. Um estudo trazia como objeto de estudo a esperança do enfermeiro frente ao cuidado de pacientes em cuidados paliativos (Kylmä et al., 2009).

Nesse estudo, a família mantém a esperança na cura mesmo após ter sido referenciada ao grupo de cuidados paliativos, sobretudo no caso das crianças com doenças oncológicas, e esta esperança a acompanha também na situação de final de vida. Quando a criança é portadora de uma condição limitante de vida, a esperança da família, no nosso caso, era a manutenção da vida pelo maior tempo possível, com o menor número de sequelas e com sintomas controlados, com o intuito, como já dito, de conseguir proporcionar a melhor qualidade de vida para o filho. Nesse sentido, a esperança para estas famílias é significado como algo que afasta o medo de perder o filho e as mantém no foco de cuidar da criança, oferecendo-Ihe a melhor qualidade de vida possível. 
Consistente com nossa pesquisa, estudo realizado com pais de crianças portadoras de tumor cerebral já falecidas demonstrou que a manutenção da esperança da cura do filho foi tema presente e recorrente em todas as entrevistas, mesmo nos estágios de final de vida. Conservar a esperança para eles representou um domínio que abrangeu a importância da esperança no sentido de dar força para a criança e família frente à adversidade e estava ligada a seus recursos de força espiritual (Zelcer et al., 2010).

Pesquisa brasileira que estudou as experiências das crianças com câncer e de suas famílias no processo de morte e morrer a partir da filosofia dos cuidados paliativos obteve resultados semelhantes com relação à esperança. $\mathrm{O}$ estudo coloca que mesmo frente à dúvida de que a cura seria possível de ser conseguida e sentindo que a morte poderia ocorrer, os pais mantiveram a esperança de que a situação pudesse ser invertida, o que os fazia viver entre o que era real e o que era desejado por eles (Zorzo, 2010).

A questão da esperança vem atrelada às crenças espirituais e religiosas da família. Sua crença em uma força divina, com um poder superior, é onde deposita suas fichas para salvar a vida do filho quando a medicina já não encontra mais recursos para a cura. Dessa forma, os estudos corroboram a importância da religião e espiritualidade para crianças e famílias que vivenciam o contexto dos cuidados paliativos, sendo um recurso mediante o qual encontra forças que as permitem lidar com a doença e o processo de morte e morrer do filho. Suas crenças e práticas estão associadas à sua perspectiva de ver a vida, questões sobre a capacidade da bondade humana e de que "[...] tudo acontece por uma razão[...]", sendo imprescindível para que consigam definir e ressignificar suas vidas após a morte da criança (Knapp et al., 2010; Hexem et al. 2011; Bergstraesser, 2012).

Vale ressaltar que a esperança em um milagre é o que pode proporcionar à família estabilidade para manter-se forte e ainda crer na recuperação do filho. Todavia, esta não exclui que a família também reconheça que a morte do filho seja uma possibilidade real e, às vezes, iminente. Para tanto, a esperança pode ser considerada uma "[...] negação saudável [...]" frente à perda do filho (Bergstraesser, 2012). 
Apesar de a família buscar sempre manter sua esperança, em certos momentos, ela pode apresentar períodos de desesperança, sobretudo diante das crises decorrentes da exacerbação da doença, recidivas no caso das doenças oncológicas e quando testemunha o sofrimento do filho e sua renúncia em seguir vivendo. Contudo, mesmo enfrentando estes períodos de adversidade, ela procura concentrar seus esforços nos resultados positivos que vêm obtendo até o momento no manejo do cuidado do filho e, com isso, reaviva a esperança de que pode continuar na caminhada pela preservação da sua vida. Dessa forma, flutuando entre a esperança e a desesperança, vai encontrando forças para equilibrar sua jornada entre o sofrimento vivido, o sentimento de perda iminente e a sonhada recuperação do filho.

A progressão de sintomas e a possibilidade de que não se consiga controlá-los, com consequente aumento de seu sofrimento é uma das grandes preocupações da família (Kars et al., 2010; Knapp et al., 2010; Bergstraesser, 2012), o que também foi evidenciado em nosso estudo e lhe representou uma carga adicional de sofrimento ao sentir-se incapaz de conseguir esse controle. No entanto, ao reconhecer os cuidados paliativos, vislumbra nestes a oportunidade de controlar sintomas que causam tanto sofrimento ao filho e, com isso, melhorar e manter sua qualidade de vida.

À medida que a doença avança, as crianças podem apresentar déficits progressivos e perda de função (Zelcer, 2010; Kars, 2011). A perda da comunicação, em particular, aparece para os pais como um ponto significativo e marcante rumo à morte do filho. Esta deteriação neurológica tem um efeito significativo na qualidade de vida da criança e família e implicações nos cuidados nessa situação. A perda da habilidade de comunicação pode afetar a habilidade de expressar emoções, desejos e sonhos, incluindo, em particular, falar sobre a morte e morrer e planificar um plano de cuidado avançado (Zelcer, 2010).

$\mathrm{Na}$ sua interação com o filho, as limitações impostas a ele pela doença são marcantes na trajetória da família. Reconhecer que ele também vivencia sua deterioação progressiva a cada dia de forma consciente causaIhe imensa dor. Assim, em meio ao desânimo e a desesperança de testemunhar o sofrimento do filho, sofre pela incapacidade de poder reverter 
a situação e por se dar conta de que, seguramente, a perda é inevitável, conscientizando-se de sua impotência diante deste doloroso e insuportável panorama, presenciando-o com uma dor incontrolável.

A análise da experiência revelou que quando a família reconhece os cuidados paliativos passa a viver um paradoxo entre continuar lutando para mantê-lo vivo - mas, em contrapartida, sabem que a possibilidade da morte é real, que o processo pode ser doloroso para o filho ao ver que a doença progride incessantemente e que os sintomas estão cada vez mais exacerbados - e a morte da criança aparecendo como uma possibilidade de acabar com o seu próprio sofrimento. Assim, os pais experienciam uma luta interior: o desejo de preservação da vida e o ímpeto de deixá-la morrer, pois testemunham a progressão da doença e o aumento do sofrimento, fato este irreversível.

Kars et al. (2011) argumentam, a partir dos resultados de seu trabalho com pais de crianças com câncer após estes terem sido notificados de que a não cura do filho era um fato consumado, que este sentimentos ambivalente dos pais pode estar presente mesmo antes do período de final de vida da criança, independentemente do estágio da doença. Durante o processo de cuidados paliativos, continua o sentimento de ambivalência alternados entre "permitir que o filho parta" e "manter a vida dele". O curso individual e a variação entre os pais frente à situação da possibilidade real, que é a proximidade da morte, estão fortemente relacionados às suas habilidades em manejar os sentimentos de perda.

Para eles, lidar com as perdas significa renúncia gradual, mas que, às vezes, precisa ser acelerado devido à deterioração física da criança relacionada à sua e falta de vontade de continuar vivendo observada no filho, em meio a tanto sofrimento (Kars et al., 2011).

A partir do momento em que os pais percebem a progressão da doença, apesar dos esforços da equipe em controlar a sintomatologia, bem como em alguns casos a perda da capacidade de comunicação da criança, eles passam a admitir a morte do filho como sendo a melhor solução diante do quadro doloroso que veem, o que os levará também ao alívio de presenciarem a dimensão deste sofrimento, cujo aumento se eleva a cada 
dia de forma ininterrupta. Este fato é corroborado por uma série de estudos que envolvem a percepção de famílias de crianças/adolescentes, notadamente na área da oncologia (Hunt et al., 2006, Kars et al., 2011; Bergstraesser, 2012).

Acreditamos que nosso estudo também esteja acrescentando uma contribuição significativa para a área de conhecimento dos cuidados paliativos pediátricos e para o atendimento a estas famílias. Ao permitir que a família narrasse sua história com o filho no decurso dos cuidados paliativos até a fase de transição para os cuidados de final de vida e morte da criança possibilitou que sua experiência também confirmasse esse 0 conceito de luto antecipatório, o qual também já vem sendo estudado na área dos cuidados paliativos e situações de final de vida (Al-Gamal e Long, 2010; Cheng et al., 2010).

Segundo Fonseca (2004, p. 93) Lindemann, em 1944, foi quem descreveu o termo "luto antecipatório" pela primeira vez ao analisar esposas de soldados que iam para a guerra. $O$ autor observou que elas experienciavam reações de luto à separação física do marido e frente à possibilidade de que estes morressem na guerra. Ao analisar o fenômeno, o compreendeu como uma reação adaptativa destas mulheres frente à probabilidade de perda do marido. Com esta reação, pareciam se proteger contra a viabilidade de serem defrontadas com a morte repentina. Assim, concluiu que este fenômeno representava uma função adaptativa para estas mulheres, o qual chamou, como já dito, de "luto antecipatório". A partir desse momento, começou a ser estudado com "[...] pessoas que recebem um diagnóstico e enfrentam as doenças terminais e a ameaça da morte iminente em suas famílias."

Rando (2000) o define como um conjunto de processos que são deflagrados a partir da progressiva ameaça de perda por paciente e pela família. É um ativo processo psicossocial de enlutamento empreendido pela família e pelo paciente na fase entre o diagnóstico e a morte.

O luto antecipatório, como o próprio nome sugere, não é um pressentimento de luto que se espera após a morte, podendo ser experienciado pelo indivíduo que está morrendo, pelos membros familiares e 
pelos profissionais de saúde. Assim, este é o luto de uma perda que ocorreu, que está ocorrendo ou que ocorrerá e uma fase onde se necessita conviver com a realidade de ter de se preparar para enfrentar a morte que se aproxima. Por outro lado, precisa dedicar toda atenção e carinho à pessoa que está morrendo, por isso não implica em afastamento de quem está morrendo ou no desligamento do vínculo, como acontece no luto pós-morte (Rando, 2000).

Assim sendo, o luto antecipatório envolve elementos de enfrentamento, interação, reorganização psicossocial, planejamento, equilíbrio das demandas e auxílio no processo de morrer (Rando, 2000, Clukey, 2008). Além disso, um aspecto essencial neste luto é encontrar significado para a própria vida (Doka, 2000).

Em nosso estudo, alguns membros familiares conseguiram verbalizar seus sentimentos relacionados ao medo da morte e à forma como imaginavam o futuro sem o filho e como conseguiriam viver sem sua presença física.

De acordo com Rando (2000), esta é uma forma positiva para ensaiar sua nova maneira de viver e antecipar problemas com a ocorrência da morte. Todavia, o autor pontua que as pessoas, em geral, que vivenciam a situação de um luto antecipatório preferem não falar sobre o futuro, uma vez que preferem se concentrar na relação enquanto a pessoa permance ao seu lado.

A possibilidade de morte do filho é perturbadora para toda a família e dificulta a visão do futuro sem a criança/adolescente; por esta razão é que o seu foco está sempre voltado para o presente. Ela aprende que pensar no futuro sem o filho é dispensar a energia de que eles precisam para continuar com determinação para manter a vida do filho, por isso, aprendem a viver um dia de cada vez.

A família busca manter sonhos e emoções do passado e faz um movimento no sentido de interromper o tempo antes do trágico evento da doença da criança. Na intenção de prolongar a presença da criança na vida familiar, a família age negando-se a falar sobre as expectativas futuras (Bousso et al., 2012). 
No contexto da oncologia pediátrica, o luto antecipatório está associado com o melhor enfrentamento do luto e a forma como os pais lidam com a morte iminente (Rando, 2000; Kreicbergs et al., 2007). Compartilhar sua situação com outras pessoas pode ser visto como uma influência positiva no desenvolvimento do luto dos pais após a morte da criança com câncer (Kreicbergs et al., 2007).

Durante o período de final de vida, os sentimentos de perda vivenciado pelos pais ganha maior proporção. A dificuldade deles em lidar com estes sentimentos resulta, como visto, em uma ambiguidade: saber que a morte é inevitável e lidar com a perda, que é um processo gradual de abandono que se manifesta em uma luta interna entre preservar a vida do filho ou "permitir" que ele morra. Vale ressaltar que esta ambiguidade não é um estado momentâneo ou relacionado exclusivamente a decisões pontuais nas situações que envolvam o cuidado no final de vida, mas está constantemente presente durante toda a experiência dos pais e dirige a vida cotidiana da família e os cuidados para com a criança (Kars et al., 2011). A esperança na cura ou recuperação, mesmo que perceba sinais de que o filho não está melhorando, mantém-se durante todo o tratamento e reforça esta ambiguidade sentida pelos pais diante da situação do filho em cuidados paliativos (Monterosso e Kristjanson, 2008).

Apesar do sentimento de perda da família frente a uma criança/adolescente em cuidados paliativos estar presente em todo 0 percurso da doença, o que pode ser compravado pelos dados desta pesquisa, estes, geralmente, só tendem a ser reconhecidos de fato somente após a sua morte, onde se tem a perda de uma relação única, que é percebida como vital por quem a vivencia (Kreicbergs et al., 2007). Manejar estes sentimentos antecipadamente é dificil e assustador para os pais cujos filhos se encontram em fase final de vida. A necessidade de se conseguir evitar a morte da criança é enorme, mas nem todos os pais estão dispostos a evitar a perda a qualquer preço. Alguns deles conseguem subordinar seus sentimentos de perda com as metas voltadas para o bem-estar da criança, reconhecendo que sua morte poderia ser a melhor solução para impedir que a continuação do sofrendo (Kars et al., 2011). 
Bousso (2006) assegura que para que a família possa iniciar sua trajetória de recuperação é importante que consiga, primeiramente, construir a realidade da morte do filho. Para tanto, precisam parar para pensar, sentir, relacionar-se e falar sobre ela; entretanto, poucos são aqueles que conseguem lidar com a morte verbalizando precocemente. Nessa jornada, parece ser mais fácil conviver com as incertezas a reconhecer que a criança em breve não sobreviverá (Rosemblatt, 2000).

A perda de um filho pode ser descrita como a morte de si mesmo em vida, que é definida como a ocorrência de "[...] um fato que obriga a pessoa a mudar os caminhos planejados e reestruturar sua vida em função de sua nova condição." (p.85). Embora seja a morte do outro, os pais simbolizam como uma parte de si que se foi (Alves, 2006).

Tal fato aparece de encontro ao nosso trabalho, dado que a vivência de uma criança/adolescente em cuidados paliativos e suas famílias pode significar uma morte de si em vida, porque as perdas sucessivas fazem com que as pessoas envolvidas na situação "tenham de" reestruturar frequentemente sua vida, por meio da elaboração de perdas de partes de si e do outro, em função das limitações que se intensificam. A importância de se conseguir ter esse fato em mente influenciará diretamente na qualidade do serviço oferecido a estas famílias e às suas crianças.

Nossos resultados indicam que os participantes inicialmente evitam discutir as implicações da doença e, por conseguinte, a morte com suas crianças. Procuram proteger seus filhos e se protegerem evitando conversas e atividades associadas à morte, por também não terem condições físicas nem psicológicas para pensar e assumir que esta possibilidade é real. Evasão e fuga são consideradas métodos de enfrentamento usados em situações onde os indivíduos apresentam pouco controle sobre elas (Folkman e Greer, 2000).

Os profissionais, dotados de compaixão e solidariedade, devem reduzir o impacto das adversidades da doença, propiciando alívio do sofrimento e a construção de novas perspectivas para a família (Remedi et al., 2009).

Com respeito às dificuldades que eles têm para se ajustar à real situação da criança em cuidados paliativos, muitos estudos confirmam que 
os pais podem reconhecer com atraso a deterioração progressiva da criança e, consequentemente, a iminência de sua morte. Isto pode ser ocasionado por atraso em reconhecer que o tratamento falhou (Wolfe et al., 2000a e 2000b), ou por atraso entre a consciência intelectual e emocioanal da morte (Valdimarsdóttir et al., 2007). Tais atrasos são frequentemente explicados pela falta de informações claras em virtude da inexperiência profissional de discutir assuntos relacionados à morte da criança (Wolfe et al., 2000b; Hurwitz et al., 2004; Valdimarsdóttir et al., 2007) juntamente a uma falta de conhecimento integrativo sobre os cuidados paliativos (Monterosso e Kristjanson, 2008). Contudo, isso também pode ocorrer pela dificuldade dos pais em lidar com a perda e por sua perspectiva em buscar adotar alternativas para manter o controle da situação, na tentativa de preservar a vida de seu filho (Kars et al., 2011).

Este estudo, em conjunto com a literatura, demonstrou que a família pode encontrar uma nova forma de continuar vivendo apesar das perdas na qual o processo de vivenciar os cuidados paliativos e a consequente morte da criança acontece com menos conflitos. Mas isto só é possível quando a contexto admite o reconhecimento do sofrimento, acolhe dúvidas, oferece informações cabíveis, permite um espaço onde a família possa compartilhar ideias e sentimentos e facilita o acesso ao suporte social. Bousso (2006) afirma que respeitar estas condições ao se trabalhar com a família permite que seus membros construam significados e uma nova realidade às experiências e interações, onde possam oferecer suporte uns aos outros, buscando diminuir o sofrimento vivenciado com a experiência.

Para que o potencial de avaliação e intervenção com famílias se concretize, torna-se necessária a criação de um contexto, no qual profissionais e famílias consigam estabelecer uma relação de parceria, confiança, comunicação regular e transparência (Bousso, 2006).

Esse cuidado com a família, que deve ser realizado gradualmente durante a trajetória dos cuidados paliativos, refletirá nas formulações posteriores de seu enfrentamento para as questões de luto e morte e no modo como conduzirá sua vida após o falecimento do ente querido. Cabe a nós, profissionais, agirmos preventivamente, emponderando, preparando, 
cuidando destes familiares durante todo esse período que pode variar de dias a anos, dependendo do diagnóstico, mas que é vivido com a mesma intensidade por estas famílias.

Dessa forma, acredita-se na responsabilidade do enfermeiro em buscar subsídios para conhecer a maneira pela qual a família tenta se reorganizar para enfrentar as demandas e mudanças impostas pelos cuidados paliativos, a fim de que possa intervir com a intenção de conseguir recuperar o equilíbrio do esquema familiar.

A família em cuidados paliativos deseja ser conhecedora do que acontece com a criança, mesmo que a verdade the cause dor e desesperança pelo que pode vir a ocorrer com o filho. Nesse sentido, manter um relacionamento de parceria e confiança com a equipe é fundamental para o fortalecimento da família e da criança (Heller e Solomon, 2005; Monterosso et al., 2007; Wood et al., 2010).

A mudança para um modelo de cuidado em parceria com a família pode potencializar os relacionamentos dos profissionais com a família, por meio de melhor comunicação e de apoio (Wilson e Huntington, 2009). O bem-estar da criança depende, em última instância, do bem-estar da mãecuidadora (Streisand et al., 2001), o que, por sua vez, em última análise, depende também da efetiva parceria dela com profissionais capacitados (Coffey, 2006). 


\section{Considerações FinAIS}


Compreender a experiência da família quando vive o processo de ter um filho em cuidados paliativos foi o desafio proposto por este trabalho, 0 que o tornou realidade ao se lançar mão dos referenciais teórico e metodológico do Interacionismo Simbólico e da Teoria Fundamentada nos Dados, respectivamente. Assim, pensar a família interacionalmente nos conduz a pensar nos significados por ela atribuídos à sua experiência.

A análise dos subprocessos identificados e da maneira como interagiam na experiência da família viabilizou identificar o processo representado pela categoria central FLUTUANDO ENTRE A ESPERANÇA E A DESESPERANÇA EM UM MUNDO TRANSFORMADO PELAS PERDAS, identificada a partir do desejo persistente das famílias de fazer o melhor para o seu filho e mantê-lo com o pensamento positivo em um contexto constantemente permeado por perdas, onde buscam incansavelmente controlar a doença, a fim de prolongar sua vida.

O modelo teórico representativo da experiência foi possível a partir da integração entre as categorias e sua articulação com a categoria central e nos proporcionou um caminho para conhecer a experiência da família da criança/adolescente em cuidados paliativos a partir dos significados por ela construídos para suas vivências e realidades, das quais a família é a principal conhecedora. Além disso, nos possibilitou conhecer a forma como lidam e buscam forças e recursos para se readaptarem a este novo contexto de cuidado e prosseguir a vida apesar da dor e do sofrimento, o que é atingido quando consegue redefinir valores e sua filosofia de vida com a ajuda das interações sociais vividas no decorrer do processo.

Dessa forma, as interações sociais vivenciadas foram imprescindíveis, tendo em vista que as interações estabelecidas entre família, criança/adolescente, profissionais de saúde e da interação de cada membro familiar consigo mesmo, por meio de reflexões e dos significados dados por 
ele à experiência, influenciaram na maneira como a família vivenciou o processo, conseguindo, dessa forma, dar um sentido aos cuidados paliativos, relacionando-o a possibilidade de se conseguir melhoria na qualidade de vida do filho, assim, pode integrá-lo no contexto familiar.

Nosso estudo demonstrou que reconhecer os cuidados paliativos para a família é uma tarefa árdua, uma vez que a coloca frente às incertezas e apreensão em relação ao futuro e à realidade da morte. É um processo de transição entre ter o filho vivo e curado para uma nova realidade, onde é possível não se conseguir controlar os sintomas e sua morte pode ser iminente.

Entretanto, quando no decorrer de sua trajetória, a família, junto com a equipe de saúde e o meio social, consegue perceber os benefícios das ações da equipe no desconforto físico do filho e, por conseguinte, de seu sofrimento, somado ao fato de que quando se sente acolhida por esta, encontrando espaços onde pode se expressar sobre suas perdas, passa a dar um novo sentido aos cuidados paliativos, começa a reconhecê-lo como uma oportunidade de aliviar o sofrimento de sua criança/adolescente. Aliado a isto, conscientizar-se de que a doença progride a cada dia, faz com que altere a sua meta, que agora deve ser a qualidade de vida e o controle de sintomas físicos ocasionados pela progressão da doença e, consequentemente, pelas desordens emocionais.

Dessa maneira, a experiência demonstra que reconhecer os cuidados paliativos não significa aceitar a morte, porque esta é uma realidade que ela nunca aceitará, mas é sua forma de tentar aprender a lidar com as perdas decorrentes ao longo do percurso e manter sua esperança e perseverança, porque é isso que a mantém com o foco no manejo do cuidado do filho. Porém, vive com sua dor e as incertezas por não saber precisar o tempo que ainda the resta junto ao filho até que a morte efetivamente os separe.

A consequência do processo vivenciado por estas famílias é a morte da criança/adolescente, a qual exige que ela se adapte à nova vida que, por certo, virá pela frente. Destarte, quando desfrutou de confiança e de momentos de continência, especialmente com a equipe de saúde que os atendeu, consegue desenvolver estratégias que favorecem uma organização da experiência. 
Desta feita, conhecer a experiência da família permite que 0 profissional de saúde identifique e reconheça suas limitações e forças de enfrentamento diante da situação e se conscientiza de que pode elaborar e executar estratégias de intervenção com a família da criança em cuidados paliativos. Os dados reforçam a importância do papel do profissional e de uma abordagem paliativa durante todo esse percurso, desde o momento do diagnóstico de uma "condição limitante de vida" ou de "uma condição que ameaça a vida" até a fase de transição para o óbito.

Acredita-se que o desafio fundamental nessa fase seja encontrar uma forma de facilitar essa transição dos cuidados curativos para os paliativos, de modo sensível, único, desafiador e solidário. Deve-se levar em consideração que a família enfrentará uma série de transições em sua trajetória e que não está restrita ao processo de morte e morrer. Assim sendo, vivencia transições da possibilidade de cura para os cuidados de conforto, relacionados às perdas, de natureza espiritual e psicológica e até de ambientes de cuidado (Davies et al., 1995).

De igual teor, este estudo corrobora que os desafios da família frente à situação de ter o filho em cuidados paliativos são enormes e que o seu sofrimento e dificuldades precisam ser reconhecidos desde o início da experiência, para que ela possa prosseguir sua jornada. Acredita-se que uma das dificuldades que surge é que a transição sugere a morte iminente da criança e, com frequência, provoca na família, além do medo da morte do filho, o medo de ser desamparada e abandonada pelos profissionais de saúde.

Acredita-se também que esbarra na formação profissional, que, apesar de estar em expansão na área dos cuidados paliativos, ainda se encontra como um desafio para a prática. A discussão referente ao momento da transição das metas de cuidado da cura para a paliação deve ser entendida como etapa fundamental quando se fala em cuidados paliativos, tendo de ser reconhecida e discutida pelos profissionais de saúde, que devem reconhecer esta assistência como uma forma de cuidado.

Apesar de não se poder generalizar, a experiência estudada possibilita avanços na área dos cuidados paliativos e também a evidência de alguns conceitos marcantes na experiência da família da criança/adolescente 
em cuidados paliativos. A escolha metodológica pela Teoria Fundamentada nos Dados, mediante os passos metodológicos de seu processo analítico, proporcionou evidenciar que os conceitos identificados se repetem ao longo das experiências, caracterizando o que se denomina de saturação teórica pertinente às pesquisas qualitativas.

Portanto, conceitos como luto antecipatório e perdas despontam como importantes constructos que possibilitariam intervir junto a estas famílias durante esse momento em suas vidas. Os conceitos aqui identificados auxiliam a compreender experiências neste contexto; contudo, é necessário que novas pesquisas sejam realizadas com o firme propósito de expandir ou mesmo alterar os conceitos aqui identificados.

A experiência prática da pesquisadora com a assistência a crianças com "condições que limitam a vida" e "condições que ameaçam a vida" e suas famílias, bem como a possibilidade de intercâmbio com outros centros referenciados na assistência paliativa em conjunto às atividades junto ao NIPPEL/USP foram de extrema importância para o presente trabalho. Isto porque, aprimoraram conhecimentos técnico e científico e também habilidade para a realização das entrevistas, as quais se constituíram em momentos muito intensos.

A literatura científica evidenciou que, em relação aos cuidados paliativos pediátricos, ainda são poucos os trabalhos que abordam experiência a partir da perspectiva da criança/adolescente. Em nosso trabalho, também não foi possível ouvir as histórias a partir da perspectiva da criança, sendo uma limitação deste estudo. Porém, a vivência prática junto a crianças/adolescentes nessa situação em conjunto com os relatos das famílias revelam a necessidade emergente de se dar voz às e suas experiências. Logo, outros estudos devem ser realizados dando maior atenção a elas nas diferentes faixas etárias e aos efeitos dos cuidados paliativos a curto, médio e longo prazos, já que hoje podemos encontrar crianças/adolescentes que permanecem nessa condição de cuidado por muitos anos.

Nesse estudo, demonstrou-se que ter a criança em casa durante a fase de cuidados paliativos permite maior autonomia, manutenção das rotinas familiares e, consequentemente, senso de continuidade da vida 
familiar. Sabe-se, hoje, que, apesar de todo o estresse vivido pelos familiares, nessa fase da doença, cuidar da criança em casa é o que se configura como uma boa qualidade de vida. É importante, pois, o investimento de programas institucionais e governamentais que trabalhem no suporte social, no emponderamento e encorajamento dessas famílias em iniciativas que melhor se adaptem a elas.

Os resultados aqui encontrados indicam a necessidade de se pensar em intervenções que vão além de minimizar os sintomas físicos da criança. O sofrimento emocional e o trabalho de tolerância da criança às demandas da doença devem ser considerados. Além disso, valores culturais, étnicos e religiosos não podem ser esquecidos. O grupo de profissionais que atende famílias de crianças em cuidados paliativos deve atuar buscando amenizar o seu sofrimento e oferecendo qualidade à sua vida em função do parco tempo que Ihes resta. Para tanto, devem ser levados em conta a carga emocional e o trabalho dos pais/mães em acompanhar seus filhos nesse doloroso momento. No entanto, é sabido que os desafios, tanto no ensino, como na prática, no âmbito das políticas públicas e mesmo na pesquisa nessa área, ainda são muitos; mas para que possam ser desenvolvidos, é substancial que sejam reconhecidos. 
7 ANEXOS 


\section{Anexo A - Ficha da Família}

\section{A) Informações referentes à criança}

1. Iniciais:

2. Idade:

3. Sexo: ( ) feminino

( ) masculino

4. Anos de Aprovação Escolar:

5. Patologia(s) e data(s) de diagnóstico:

6. Início de acompanhamento no grupo de cuidados paliativos:

7. Como chegou ao grupo:

8. Total (estimado) de consultas ou tempo de acompanhamento na unidade de cuidados paliativos:

9. Condutas:

10. Acompanha com outra especialidade (especificar): 


\section{B) Informações referentes à família}

- Nome:

- Membros da família presentes na entrevista:.

- Local e data da entrevista:

- Genograma da Família: (nomes, idades, posição na família, atividades e outros dados significativos como: doença familiar, óbito, aborto, adoção, casamento, divórcio)

Avós

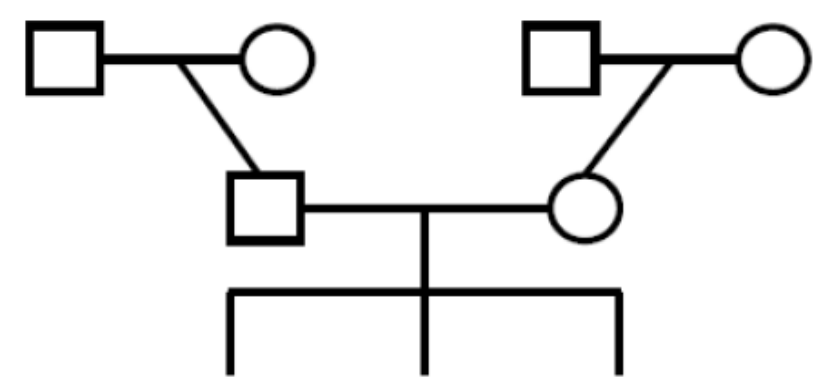

Filhos

- Ecomapa da Família (relações significativas entre os subsistemas familiares, família extensa e sistemas mais amplos

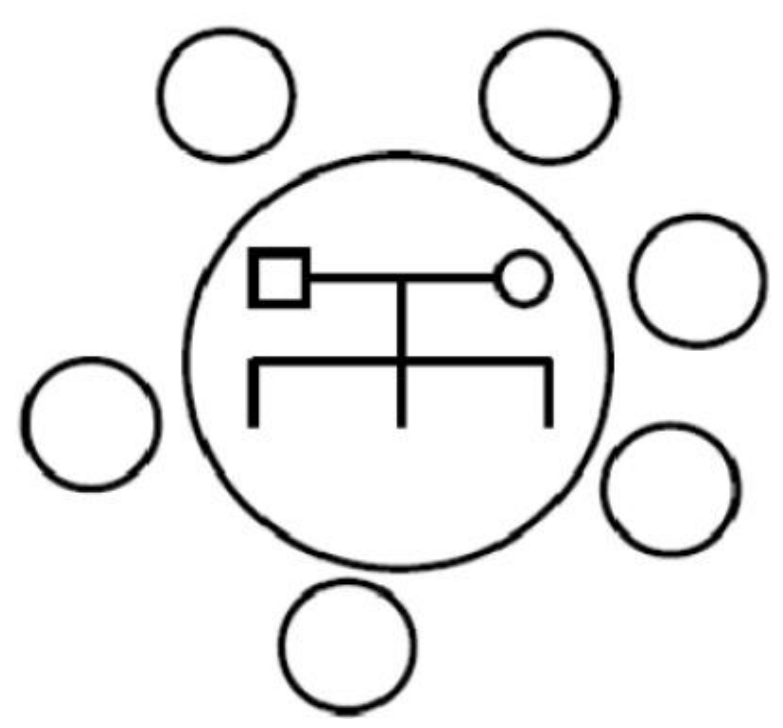




\title{
Anexo B - Aprovação do Comitê de Ética da EEUSP
}

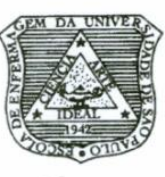

-

\author{
UNIVERSIDADE DE SÃO PAULO \\ ESCOLA DE ENFERMAGEM \\ Av. Dr. Enéas de Carvalho Aguiar, 419 - CEP 05403-000 \\ ¿.2 Fone.: 3061-7548 - Fax.: 3061-7548 \\ C.P. 41633 - CEP 05422-970 - e-mail.: edipesq@usp.br
}

São Paulo, 28 de maio de 2008.

Ilm. ${ }^{\text {a }}$ Sr. ${ }^{\text {a }}$

Prof. ${ }^{\mathrm{a}}$ D. ${ }^{\mathrm{a}}$ Regina Szylit Bousso

Ref.: Processo $n^{\circ}$ 739/2008/CEP-EEUSP

Prezada Senhora,

Em atenção à solicitação referente à análise do projeto "Qualidade de vida em cuidados paliativos de pediatria: perspectiva da criança e da família”, informamos que o mesmo foi considerado aprovado pelo Comitê de Ética em Pesquisa da Escola de Enfermagem da Universidade de São Paulo (CEP/EEUSP).

Analisado sob o aspecto ético-legal, atende às exigências da Resolução $\mathrm{n}^{\circ}$ 196/96 do Conselho Nacional de Saúde.

Esclarecemos que após o término da pesquisa, os resultados obtidos deverão ser encaminhados ao CEP/EEUSP, para serem anexados ao processo.

Atenciosamente,

$$
\begin{aligned}
& \text { P/ Prof. }{ }^{\text {a }} \text { Dr. }{ }^{a} \text { Maria de Fátima Prado Fernandes } \\
& \text { Coordenadora do Comitê de Ética em Pesquisa da } \\
& \text { Escola de Enfermagem da Universidade de São Paulo }
\end{aligned}
$$




\section{Anexo C - Aprovação do Comitê de Ética da IC-HC}

\begin{tabular}{|c|c|}
\hline MFN: 0748 & PROPES.MST \\
\hline $\begin{array}{l}\text { Num. do Protocolo: } \\
\text { Data de Entrada: } \\
\text { Autor Responsavel: } \\
\text { Autores: }\end{array}$ & $\begin{array}{l}00748200840 \\
07 / 07 / 2008 \\
\text { Maira Deguer Misko (Misko MD) } \\
\text { Maira Deguer Misko (Misko MD) } \\
\text { Regina Szylit Bousso (Bousso RS) }\end{array}$ \\
\hline $\begin{array}{l}\text { Linha de Pesquisa: } \\
\text { Descrição: }\end{array}$ & $\begin{array}{l}\text { Qualidade de vida da criança e do adolescente e de seu núcleo social. } \\
\text { A maior parte das afecçōes crônicas acarreta grande limitaçāo, aos pacientes e } \\
\text { seus cuidadores. O conhecimento dos fatores que afetam a qualidade de vida } \\
\text { destes individuos poderá resultar em intervençóes. }\end{array}$ \\
\hline Titulo do Projeto: & $\begin{array}{l}\text { Qualidade de vida em cuidados paliativos de pediatria: perspectiva da criança e } \\
\text { da familia }\end{array}$ \\
\hline Descrição: & $\begin{array}{l}\text { Serão entrevistados membros das famílias de crianças que estão em } \\
\text { acompanhamento ambulatorial em serviços de cuidados paliativos, na faixa etária } \\
\text { de } 6 \text { até } 18 \text { anos, independentes da patologia. Esta faixa etária foi escolhida, pois } \\
\text { é sabido que crianças em idade escolar possuem um discurso bem desenvolvido, } \\
\text { o que Ihes permite compreender explicaçōes e informar verbalmente sobre o que } \\
\text { pensam e sentem. O número de famílias vai se configurando em razăo de análise } \\
\text { de seus depoimentos. A coleta de dados será realizada atéo acontecer a } \\
\text { saturaçăo teórica, quando se verifica repetiçăo e ausência de dados novos, e } \\
\text { crescente compreensão dos conceitos identificados. Há estimativa de coletar } \\
\text { dados em vinte familias. As estratégias adotadas para a coleta de dados serão a } \\
\text { foto imagem e a entrevista. Ambas são consideradas recursos importantes à } \\
\text { compreensão da experiência da familia. Inicialmente serăo oferecidas máquinas } \\
\text { fotográficas para que os participanmtes registrem dez imagens que representem } \\
\text { uma boa qualidade de vida e outras dez que representem má qualidade de vida. A } \\
\text { entrevista tem início com a apresentaçăo das imagens para os participantes e a } \\
\text { solicitaçăo para que eles selecionem de quatro a seis imagens que considerem } \\
\text { mais significativas e representativas de qualidade de vida ou falta desta. O } \\
\text { procedimento será realizado da seguinte forma: inicialmente conversaremos com } \\
\text { os membros da família presentes no serviço ambulatorial de cuidados paliativos } \\
\text { para certificar-nos de seu interesse em participar do estudo. Será esclarecido o } \\
\text { objetivo da pesquisa e dúvidas que eles tenham em relaçăo à esta. (De Outra } \\
\text { Área) }\end{array}$ \\
\hline Unidade(s) Executora(s): & Ambulatório de Dor e Cuidados Paliativos do ICr \\
\hline Prazo Inicio: & $01 / 09 / 2008$ \\
\hline Chefia de Area: & Exequivel 03/07/2008 \\
\hline Comissão de Pesquisa: & Aprovado Magda Maria Sales Carneiro Sampaio 04/08/2008 \\
\hline Relator Comissão: & Aprovado Divanice Contim 31/07/2008 \\
\hline Chefe departamento: & Sandra Josefina Ferraz Ellero Grisi \\
\hline CAPPesq N. Protocolo: & Aprovado 739/08 Escola de Enfermagem da USP - EEUSP 28 / 05 / 2008 \\
\hline
\end{tabular}

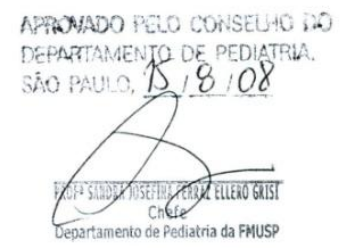




\section{Anexo D-Termo de Consentimento Livre e Esclarecido para participação na pesquisa científica}

\section{TERMO DE CONSENTIMENTO LIVRE E ESCLARECIDO}

Meu nome é Maira Deguer Misko, enfermeira, doutoranda da Escola de Enfermagem da Universidade de São Paulo. Estou realizando uma pesquisa que pretende compreender a experiência da família da criança/adolescente em cuidados paliativos. Para tanto, estou entrevistando famílias que aceitem voluntariamente contar-me a respeito de sua experiência de acompanhar a criança neste processo, com a finalidade de oferecer subsídios para o cuidado nessa situação.

A entrevista será realizada em local privado de sua escolha e, seu conteúdo será gravado para posterior transcrição e análise dos dados. As fitas das entrevistas permanecerão guardadas com a pesquisadora e somente ela terá acesso a seu conteúdo.

São garantidos o sigilo das informações, o anonimato dos participantes, bem como a possibilidade de deixar de participar deste estudo a qualquer momento, mesmo após ter assinado o termo, ou seja, você poderá retirar seu consentimento, em qualquer fase da pesquisa, sem penalização alguma ou prejuízo à você ou à criança.

Se, após a concessão da entrevista, em algum momento, desejar que os dados não devam mais ser utilizados, você poderá contatar a pesquisadora, com a certeza da devolução da fita gravada, bem como destruição da transcrição.

Em qualquer etapa do estudo, você terá acesso à pesquisadora responsável para esclarecimento de eventuais dúvidas nos telefones (11) 3061-7610 ou (11) 96659647 ou no seguinte endereço: Av. Dr. Enéas de Carvalho Aguiar, 419 - 05403-000 - São Paulo - SP. Email: mairadm@usp.br

Os resultados obtidos serão divulgados em eventos e publicações científicas.

Este documento possui duas vias, uma ficará em posse da entrevistada e a outra arquivada com a pesquisadora, Maira Deguer Misko.

\section{CONSENTIMENTO PÓS-ESCLARECIDO}

Acredito ter sido suficientemente informado a respeito das informações que li ou que foram lidas para mim. Discuti com a pesquisadora Maira Deguer Misko sobre a minha decisão em participar nesse estudo. Ficaram claros para mim quais são os propósitos do estudo, os procedimentos a serem realizados, seus desconfortos e riscos, as garantias de confidencialidade e de esclarecimentos permanentes. Concordo voluntariamente em participar deste estudo e poderei retirar o meu consentimento a qualquer momento, antes ou durante o mesmo, sem penalidades ou prejuízo para qualquer membro de minha família.

São Paulo, de de 20. 


\section{REFERÊNCIAS}


ACT. A guide to the development of children's palliative care services. $3^{\underline{a}}$ ed. Bristol: ACT/RCPCH. 20092009.

Al-Gamal E, Long T. Anticipatory grieving among parents living with a child with cancer. J Adv Nurs. 2010; 66(9):1980-90.

Alves EGR. Pedaços de mim: luto vivido por pessoas com deformidade facial adquirida pós-trauma bucomaxilofacial e sua interferência no seu desenvolvimento [tese]. São Paulo: Instituto de Psicologia da Universidade de São Paulo, 2006.

Ângelo M, Bousso RS, Rossato LM, Damião EBC, Silveira AO, Castilho AMCM, Rocha MCP. Família como categoria de análise e campo de investigação em enfermagem. Rev Esc Enferm USP. 2009; 43(Esp. 2):133741.

Araujo MMT. Comunicação em cuidados paliativos: proposta educacional para profissionais de saúde. São Paulo: Escola de Enfermagem, Universidade de São Paulo; 2011.

Barbosa SMM, Lecussan P, Oliveira FFT de. In: Conselho Regional de Medicina do Estado de São Paulo (CREMESP). Cuidado Paliativo. São Paulo: CREMESP; 2008. p.128-38.

Barbosa SMM. Qualidade de vida e cuidados paliativos em pediatria.In Assumpção Jr. FB, Kuczynski E et al. Porto Alegra: Artmed. 2010. 127-34.

Berendes D, Keefe FJ, Somers TJ, Kothadia SM, Porter LS, Cheavens JS. Hope in the context of lung cancer: relationships of hope to symptoms and psychological distress. J Pain Symptom Manage. 2010;40(2):174-82.

Berger PL, Luckmann T. A construção social da realildade: tratado do sociologia do conhecimento. 24ํㅡㄹ ed. Petrópolis: Vozes; 2004 
Bergstraesser E. Pediatric palliative care-when quality of life becomes the main focus of treatment. Eur J Pediatr. 2012 Apr 3. [Epub ahead of print]

Bluebond-Langner M, Belasco JB, Goldman A, Belasco C. Understanding parents' approaches to care and treatment of children with cancer when standard therapy has failed. J Clin Oncol. 2007; 25(17):2414-9.

Blum K, Sherman DW. Understanding the experience of caregivers: a focus on transitions. Semin Oncol Nurs. 2010;26(4):243-58.

Blumer H. Symbolic interactionism: perspective and method. Englewood Cliffis, Prentience-Hall, 1969.

Bousso RS, Misko MD, Mendes-Castillo AM, Rossato LM. Family management style framework and its use with families who have a child undergoing palliative care at home. J Fam Nurs. 2012;18(1):91-122.

Bousso RS. Buscando preservar a integridade da unidade familiar: a família vivendo a experiência de ter um filho na UTI [tese]. São Paulo: Escola de Enfermagem, Universidade de São Paulo; 1999.

Bousso RS. Um tempo para chorar: A família dando sentido à morte prematura do filho [Livre-Docência]. São Paulo: Escola de Enfermagem, Universidade de São Paulo; 2006.

Bryant A. A constructive/ist response to glaser [serial on the Internet]. FQS. 2003. 4(1):[about 7 p]. Disponivel em: <http://www.qualitativeresearch.net/index.php/fqp/fqs/article/view/757/1643>. Acesso em 15 jun 2010.

Bryant A. Reasarch Training 2 day Workshop - Grounded Theory Method Prof Tony Bryant [video on the Internet]. Leeds; 2009. Dispoível em <htto://youtube.com/watch?v=fmWKf5LOmfA. Acesso em 15 jun 2010.

Burden J, Roodt G. Grounded theory and its application in a recent study organisation redesing: some reflections and guidelines. South Afr J Hum Resource Man. 2007; 5(3):11-8.

Burr WR, Leigt GK, Constantine J. Symbolic interaction in the family in the family. In: Burr WR, Hill R, Nye FI, Reiss IL. Contemporary theories about the family. New York: Guilford; 1979. p. 42-111. 
Charon JM. Symbolic interacionism, an introduction, an interpretation, as integration. 9aㅡ ed. Upper Saddle River: Person, 2007.

Charon JM. Symbolic interacionism: an introduction an interpretation, an integration. $3^{\mathrm{a}}$ ed. Englewood Cliffs: Prentice-Hall, 1989.

Charon JM. Symbolic interactionism: an introduction, an interpretation, an integration. $3^{\text {rd }}$ ed. New Jersey: Pearson Prentice Hall; 2004.

Cheng JO, Lo RS, Chan FM, Kwan BH, Woo J. An exploration of anticipatory grief in advanced cancer patients. Psychooncology. 2010 Jul;19(7):693-700.

Clukey L. Anticipatory mourning: processes of expected loss in palliative care. Int J Palliat Nurs. 2008;14(7):316, 318-25.

Coffey JS. Parenting a child with chronic illness: a metasynthesis. Pediatr Nurs.2006; 32(1):51-9.

Conselho Nacional de Saúde (CNS). Resolução $\mathrm{n}^{\square}$ 196, de 10 de outubro de 1996. Diretrizes e normas regulamentadoras de pesquisas envolvendo seres humanos. Bioética. 1996; 4(2Supl):15-25.

Contro N, Larson J, Scofield S, Sourkes B, Cohen HJ. Family perspectives on the quality of pediatric palliative care. Arch Pediatr Adolesc Med. 2002;156(1): 14-9.

Contro NA, Larson J, Scofield S, Sourkes B, Cohen HJ. Hospital staff and family perspectives regarding quality of pediatric palliative care. Pediatrics. 2004;114(5):1248-52.

Corkin DA, Price J, Gillespie E. Respite care for children, young people and families-are their needs addressed? Int J Palliat Nurs. 2006;12(9):422-7.

D'Agostino NM, Berlin-Romalis D, Jovcevska V, Barrera M. Bereaved parents' perspectives on their needs. Palliat Support Care. 2008 Mar;6(1):3341.

Davies B, Reimer JC, Brown P, Martens N. Fading away - The experience of transition in families with terminal illness. New York, NY: Baywood, 1995. 
deCinque N, Monterosso L, Dadd G, Sidhu R, Macpherson R, Aoun S. Bereavement support for families following the death of a child from cancer: experience of bereaved parents. J Psychosoc Oncol. 2006; 24(2):65-83.

Denzin NK, Lincoln YS. Introdução : a disciplina e a prática da pesquisa qualitativa. In Denzin NK, Lincoln YS. O planejamento da pesquisa qualitativa. Porto Alegre: Artmed, 2006. p. 15-41.

Doka K. Re-creating meaning in the face of illness. In Rando T (ed.). Clinical dimensions of anticipatory mourning: the ory and practie in working with the dying, their loved ones, and their caregivers. Champaign: Reseaarch Press, 2000. p. 103-14.

Duggleby W, Holtslander L, Kylma J, Duncan V, Hammond C, Williams A. Metasynthesis of the hope experience of family caregivers of persons with chronic illness. Qual Health Res. 2010;20(2):148-58.

Dumont S, Turgeon J, Allard P, Gagnon P, Charbonneau C, Vezina L. Caring for a loved one with advanced cancer: determinants of psychological distress in family caregivers. J Palliat Med. 2006; 9(4):912-21.

Dussel V, Joffe S, Hilden JM, Watterson-Schaeffer J, Weeks JC, Wolfe J. Considerations about hastening death among parents of children who die of cancer. Arch Pediatr Adolesc Med. 2010;164(3):231-7.

Dussel V, Kreicbergs U, Hilden JM, Watterson J, Moore C, Turner BG, Weeks JC, Wolfe J. Looking beyond where children die: determinants and effects of planning a child's location of death. J Pain Symptom Manage. 2009;37(1):33-43.

Dussel V, Medin G. Pediatrics issues. In: Bruera E, De Lima L,Wenk R, Farr $W$, editors. Palliative care in the developing World:principles and practice. Houston: IAHPC Press. 2004. p.227-56.

Edwards KE, Neville Ba, Cook EF Jr, Aldridge SH, Dussel V, Wolfe J. Understanding of prognosis and goals of care among couples whose child died of cancer. J Clin Oncol. 2008;26(8):1310-5.

Feeley N; Gottlieb LN. Nursing approaches for working with family strengths and resources. J Fam Nurs. 2000; 6(1):9-24. 
Feudtner C, Hays RM, Haynes G, Geyer JR, Neff JM, Koepsell TD. Deaths attributed to pediatric complex chronic conditions: national trends and implications for supportive care services. Pediatrics. 2001;107(6):E99.

Feudtner C, Kang TI, Hexem KR, Friedrichsdorf SJ, Osenga K, Siden $\mathrm{H}$ et al. Pediatric palliative care patients: a prospective multicenter cohort study. Pediatrics. 2011; 127(6):1094-101.

Flick U. Desenho da pesquisa qualitativa. Porto Alegre: Armed, 2009.

Floriani CA. Home-based palliative care: challenges in the care of technology-dependent children. J Pediatr (Rio J). 2010;86(1):15-20.

Folkman S, Greer S. Promoting psychological well-being in the face of serious illness: when theory, research and practice inform each other. Psychooncology. 2000;9(1):11-9.

Fonseca JP. Luto antecipatório. As experiências pessoais, familiares e sociais diante de uma morte anunciada. Campinas: Livro Pleno, 2004. 183p.

Frank AW. What is dialogical research, and why should we do it? Qual Health Res. 2005 Sep;15(7):964-74.

Gibbs GR. Grouded Theory: core elements [video on the Internet]. Huddersfield: Online QDA; 2010.2 Dispoível em <http://onlineqda.hud.ac.uk/movies/Grpimded_Tjepru/oimdex.pjp. Acesso em 15 jun 2010.

Glaser BG, Strauss AL. The discovery of grouded theory. New York: Aldine, 1967.

Glaser CL.Theoritical sensitivity. Mill Valley: The Sociology Press, 1978.

Harrys MB. Palliative care in children with cancer: which childand when? J Nat Cancer Inst Monogr. 2004;32:144-9.

Haut C. Oncological emergencies in the pediatric intensive care unit. AACN Clin Issues. 2005; 16(2): 232-45. 
Hays RM, Valentine J, Haynes G, Geyer JR, Villareale N, McKinstry B, Varni JW, Churchill SS. The Seattle Pediatric Palliative Care Project: effects on family satisfaction and health-related quality of life. $J$ Palliat Med. 2006;9(3):716-28.

Heller KS, Solomon MZ, For the Initiative for Pediatric Palliative Care (IPPC) Investigator Team. Continuity of care and caring: what matters to parents of children with life-threatening conditions. J Pediatr Nurs. 2005;20(5): 335-46.

Hexem KR, Mollen CJ, Carroll K, Lanctot DA, Feudtner C. How parents of children receiving pediatric palliative care use religion, spirituality, or life philosophy in tough times. J Palliat Med. 2011; 14(1):39-44.

Himelstein BP,Hilden JM, Boldt AM, Weissman D. Pediatric palliative care. N Engl J Med. 2004;350:1752-62.

Himelstein BP. Palliative care in pediatrics. Anesthesiol Clin North America. 2005; 23:837-856.

Hinds PS, Oakes L, Furman W, Quargnenti A, Olson MS, Foppiano P, et al. End-of-life decision making by adolescents,parents, and healthcare providers in pediatric oncology. Cancer Nurs. 2001;24(2):122-34.

Hinds PS, Schum L, Baker JN, Wolfe J. Key factors affecting dying children and their families. J Palliat Med. 2005;8 Suppl 1:S70-8.

Holtslander LF. Ways of knowing hope: Carper's fundamental patterns as a guide for hope research with bereaved palliative caregivers. Nurs Outlook. 2008;56(1):25-30.

Hsiao JL, Evan EE, Zeltzer LK. Parent and child perspectives on physician communication in pediatric palliative care. Palliat Support Care. 2007; 5(4): 355-65

Hunt H, Valdimarsdottir U, Mucci L, Kreicbergs U, Steineck G. When death appears best for the child with severe malignancy: a nationwide parental follow-up. Palliat Med. 2006;20(6):567-77.

Hurwitz CA, Duncan J, Wolfe J. Caring for the child with cancer at the close of life: "there are people who make it, and I'm hoping I'm one of them". JAMA. 2004 Nov 3;292(17):2141-9. 
Hutton N, Jones B, Hilden JM. From cure to palliation: managing the transition. Child Adolesc Psychiatr Clin N Am. 2006;15(3): 575-84, vii.

Hyson JL. The childs journey: transition fron health to ill-health. In Goldman A, hain R, Liben S. Oxford Textbook of palliative care. London: Oxford University Press, 2006. p. 14-26.

Johnston DL, Nagel K, Friedman L, Meza JL, Hurwitz CA, Friebert S. Availability and use of palliative care and end-of-life services for pediatric oncology patients. J Clin Oncol. 2008;26:4646-50.

Kaasa S, Loge JH. Quality of life in palliative care: principles and practice. Palliative Medicine. 2003;17(1):11-20.

Kars MC, Grypdonck MH, Beishuizen A, Meijer-van den Bergh EM, van Delden JJ. Factors influencing parental readiness to let their child with cancer die. Pediatr Blood Cancer. 2010;54(7):1000-8.

Kars MC, Grypdonck MH, de Korte-Verhoef MC, Kamps WA, Meijer-van den Bergh EM, Verkerk MA et al. Parental experience at the end-of-life in children with cancer: 'preservation' and 'letting go' in relation to loss. Support Care Cancer. 2011; 19(1):27-35.

Klassen A, Klaassen R, Dix D, Pritchard S, O'Donnell M, Scott A, Sung L. Impact of caring for a child with cancer on parent's quality of life. J Clin Oncol. 2008;26(36):5884-9.

Knapp C, Madden V, Wang H, Curtis C, Sloyer P, Shenkman E. Spirituality of parents of children in palliative care. J Palliat Med. 2011;14(4):437-43.

Knapp CA, Madden VL, Curtis CM, Sloyer P, Shenkman EA. Family support in pediatric palliative care: how are families impacted by their children's illnesses? J Palliat Med. 2010 Apr;13(4):421-6.

Konrad SC. Mother's Perspectives on Qualities of Care in their relationships with health care professionals: the influence of relational and communicative competencies. J Soc Work End Life Palliat Care. 2008; 4(1): 38-56.

Kovács MJ. Pacientes em estágio avançado da doença, a dor da perda e da morte. In Carvalho MMMJ (Org.). dor: um estudo multidisciplinar. São Paulo: Summus, 1999. p. 318-37. 
Kreicbergs U, Valdimarsdóttir U, Onelöv O, Steineck G, Henter JL. Carerelated distress: a nationwide study of parents who lost their child to cancer. J Clin Oncol. 2005;23(36): 9162-71.

Kreicbergs UC, Lannen P, Onelov E, Wolfe J. Parental grief after losing a child to cancer: impact of professional and social support on long-term outcomes. J Clin Oncol. 2007 Aug 1;25(22):3307-12.

Kurashima AY, de Camargo B. Cuidados Paliativos: Aliviar sem Curar. In: de Camargo B, Kurashima AY. Cuidados Paliativos em Oncologia Pediátrica: O cuidar além do curar. São Paulo: Ed. Lemar; 2007. p.39-58.

Kylmä J, Duggleby W, Cooper D, Molander G. Hope in palliative care: an integrative review. Palliat Support Care. 2009;7(3):365-77.

Lenton S, Goldman A, Eaton N, Southall D. Development and epidemiology. In Goldman A, hain R, Liben S. Oxford Textbook of palliative care. London: Oxford University Press, 2006. p. 14-26.

Lima RAG. Experiências de pais e de outros familiares de crianças e adolescentes com câncer: bases para os cuidados paliativos [livre-docência]. Ribeirão Preto: Escola de Enfermagem de Ribeirão Preto, Universidade de São Paulo; 2002.

Ludke M, Andre MEDA. Pesquisa em educação: abordagens qualitativas. São Paulo: EPU, 1986.

Maciel MGS. Definições e Princípios. In: Conselho Regional de Medicina do Estado de São Paulo (CREMESP). Cuidado Paliativo. São Paulo: CREMESP; 2008. p. 16-32.

Marsella A. Exploring the literature surrounding the transition into palliative care: a scoping review. Int J Palliat Nurs. 2009;15(4):186-9.

Masera G, Spinetta JJ, Jankovic M, Ablin AR, D'Angio GJ, Van Dongenmelman J,et al. Guidelines for assistance to terminally ill children with cancer: a report of the SIOP Working Commit tee on psychosocial issues inpediatric oncology. Med Pediatr Oncol. 1999;13:1-9.

Matsumoto DY. Cuidados paliativos: conceito, fundamentos e princípios. In Academia Nacional de Cuidados Paliativos. Manual de cuidados paliativos. Rio de Janeiro: Diagraphic, 2009. 
McCarthy MC, Clarke NE, Ting CL, Conroy R, Anderson VA, Heath JA. Prevalence and predictors of parental grief and depression after the death of a child from cancer. J Palliat Med. 2010; 13(11):1321-6.

McClement SE, Chochinov HM. Hope in advanced cancer patients. Eur J Cancer. 2008;44(8):1169-74.

Mead GH. Mind, self and society: from a standpoint of a social behaviorist. 18 ${ }^{\underline{a}}$ ed. Chicago: The University of Chicago Press, 1972.

Menezes A. Moments of realization: life-limiting illness in childhood-perspectives of children, young people and families. Int J Palliat Nurs. 2010; 16(1):41-7.

Meyer EC, Ritholz MD, Burns JP, Truog RD. Improving the quality of end-oflife care in the pediatric intensive care unit: parents' priorities and recommendations. Pediatrics. 2006;117(3):649-57.

Minayo MCS, Hartz ZMA, Buss PM. Qualidade de Vida e Saúde: um debate necessário. Ciência \& Saúde Coletiva. 2000; 5(1):7-18.

Misko MD, Bousso RS. Manejando o câncer e suas intercorrências: a família decidindo pela busca ao atendimento de emergências para o filho. Rev Latino-am Enfermagem. 2007;15(1):48-54.

Misko MD. Manejando o câncer e suas intercorrências: a família decidindo pela busca ao atendimento de emergências para o filho [dissertação]. São Paulo: Escola de Enfermagem, Universidade de São Paulo; 2005.

Misko MD. Sei que um dia vou perdê-lo. É difícil para mim: expectativas, necessidades e sentimentos expressados por acompanhantes de crianças hospitalizadas com doenças crônicas e incapacitantes [monografia]. São Paulo: Curso de Especialização em Enfermagem Pediátrica do Instituto da Criança do Hospital das Clínicas; 2001.

Mitchell W, Clarke S, Sloper P. Survey of psychosocial support provided by UK paediatric oncology centers. Arch Dis Child. 2005;90:796-800.

Monterosso L, Aoun, S, Kristjanson, LK, Philips M. Supportive and palliative care needs of families of children with life-threatening illness in Western Australia:evidence to guide the development of a palliative care service. Palliat Med. 2007;21(8):689-96. 
Monterosso L, Kristjanson LJ, Phillips MB. The supportive and palliative care needs of Australian families of children who die from cancer. Palliat Med. 2009; 23(6):526-36.

Monterosso L, Kristjanson LJ. Supportive and palliative care needs of families of children who die from cancer: an Australian study. Palliat Med. 2008;22(1):59-69.

Morse JM, Richards L. Qualitative research design. In: Readme first for a user's guide to qualitative methods. California: Sage; 2002. p. 65-84.

Nadeau JW. Families making sense of death. California: Sage Publications; 1998.

Nelson RM, Botkin JR, Kodish ED, et al. American Academy of Pediatrics. Committee on Bioethics and Committee on Hospital Care. Palliative care for children. Pediatrics. 2000; 106: 351-357.

Organização Mundial de Saúde (OMS). Cuidados inovadores para condições crônicas: componentes estruturais de ação. Relatório Mundial Genebra: Brasil; 2002.

Paganini MC. As situações de final de vida na unidade de terapia intensiva: o enfermeiro no processo de exercer a sua autonomia [dissertação]. São Paulo: Escola de Enfermagem, Universidade de São Paulo; 2011

Poles K, Bousso RS. Compartilhando o processo de morte com a família: a experiência da enfermeira na UTI pediátrica. Rev Latino-am Enfermagem. 2006; 14(2):207-13.

Price J, Jordan J, Prior L, Parkes J. Living through the death of a child: a qualitative study of bereaved parents' experiences. Int J Nurs Stud. 2011; 48(11):1384-92.

Pritchard M, Burghen E, Srivastava DK, Okuma J, Anderson L, Powell B, Furman WL, Hinds PS. Cancer-related symptons most concerning to parents during the last week and last day of their child's life. Pediatrics. 2008; 121(5): 301-9.

Rabello CA, Rodrigues PH. Saúde da família e cuidados paliativos infantis: ouvindo os familiares de crianças de dependentes de tecnologia. Cien Saude Colet. 2010 Oct;15 Suppl 2:3157-66. 
Rallison L, Moules NJ. The unspeakable nature of pediatric palliative care: Unveiling many cloaks. J Fam Nurs. 2004; 10(3), 287-301

Rando $\mathrm{T}$ (ed.). Clinical dimensions of anticipatory mourning: the ory and practie in working with the dying, their loved ones, and their caregivers. Champaign: Reseaarch Press, 2000.

Remedi PP, Mello DF de, Menossi MJ, Lima RAG de. Cuidados paliativos para adolescentes com câncer: uma revisão da literatura. Rev Bras Enferm. 2009; 62(1):107-12.

Rodrigues IG. Cuidados Paliativos: Análise de Conceito [dissertação]. Ribeirão Preto: Escola de Enfermagem de Ribeirão Preto, Universidade de São Paulo; 2004.

Rolland JS. Ajudando famílias com perdas antecipadas. In Walsh F; Goldrick MMC. Morte na família: sobrevivendo às perdas. Porto Alegre: Artes Médicas, 1998. p. 57-64

Ronaldson S, Devery K. The experience of transition to palliative care services: perspectives of patients and nurses. Int $J$ Palliat Nurs.2001;7(4):171-7.

Rosenblatt PC. Parent grief: narratives of loss and relationship. Philadelphia: Taylor \& Francis Group; 2000.

Rubin HJ, Rubin IS. Qualitative interviewing: the art of hearing data. Thousand Oaks: Sage; 1995.

Salgueiro JP. Descrição e compreensão dos processos de perdas e luto vivenciados por uma pessoa com escleroso lateral amiotrófica [tese]. São Paulo: Instituto de Psicologia da Universidade de São Paulo; 2008.

Schneider M, Steele R, Cadell S, Hemsworth D. Differences on psychosocial outcomes between male and female caregivers of children with life-limiting illnesses. J Pediatr Nurs. 2011;26(3):186-99.

Seymour J, Clark D, Winslow M. Pain and palliative care: the emergence of new spcialties. J Pain Symptom Manage. 2005;29(1):2-13. 
Silva EP da, Sudigursky D. Concepções sobre cuidados paliativos:revisão bibliográfica. Acta Paul Enferm. 2008;21(3):504-8.

Silva L. O processo de cuidar de famílias de idosos em situação de final de vida na estratégia saúde da família [tese]. São Paulo: Escola de Enfermagem, Universidade de São Paulo; 2011.

Stotland E. The psychology of hope. San Francisco: Jossey-Bass; 1969.

Strauss A, Corbin J. Basics of qualitative research: grounded theory procedures and techniques. California: Sage, 1990.

Strauss A, Corbin J. Pesquisa qualitativa: técnicas e procedimentos para o desenvolvimento de teoria fundamentada. Porto Alegre: Artmed, 2008.

Streisand R, Braniecki S, Tercyak KP, Kazak AE. Childhood illness-related parenting stress:the pediatric inventory for parents. Journal of Pediatric Psychology.2001;26:155-162.

Sutherland $\mathrm{N}$. The meaning of being in transition to end-of-life care for female partners of spouses with cancer. Palliat Support Care. 2009;7(4):423-33.

Thorne S, Darbyshire P. Land mines in the field: a modest proposal for improving the craft of qualitative health research. Qual Health Res. 2005 Oct;15(8):1105-13.

Titus B, de Souza R. Finding meaning in the loss of a child: journeys of chaos and quest. Health Commun. 2011;26(5):450-60.

Twycross R. Cuidados Paliativos. 2a ed. Lisboa: Climensi; 2003.

Valdimarsdóttir U, Kreicbergs U, Hauksdóttir A, Hunt H, Onelöv E, Henter J et al. Parents' intellectual and emotional awareness of their child's impending death to cancer: a population-based long-term follow-up study. Lancet Oncol. 2007 Aug;8(8):706-14.

Vichers J, Thompson A, Collins GS, Childs M, Hain, R. Place and Provision of Palliative Care for Children with progressive cancer: a study by the Paediatric Oncology Nurses' forum/United Kingdom Children's cancer study group palliative care working group. J Clin Oncol. 2007; 25(28):4472-6. 
Vollenbroich R, Duroux A, Grasser M, Brandstätter M, Borasio GD, Führer M. Effectiveness of a pediatric palliative home care team as experienced by parents and health care professionals. J Palliat Med. 2012;15(3):294-300.

Walsh F, McGoldrick M. Morte na família: sobrevivendo às perdas. São Paulo: Artmed; 1998.

Ware J, Raval H. A qualitative investigation of fathers' experiences of looking after a child with a life-limiting illness, in process and in retrospect. Clin Child Psychol Psychiatry. 2007; 12(4):549-65.

WHOQOL Group. The World Health Organization Quality of Life Assessment (WHOQOL): development and general psychometric properties. Soc.Sci. Med. 1998;46(12):1569-85.

Widger K, Picot C. Parents' perceptions of the quality of pediatric and perinatal end-of-life care. Pediatr Nurs. 2008;34(1):53-8.

Willis E. Symptom care flowcharts: a case study. Paediatr Nurs. 2007;19(1):14-7.

Wilson $\mathrm{H}$, Huntington A. An Exploration of the Family Partnershipmodel in New Zealand. School of Health and Social Services Massey University, Wellington, 2009.

Wolfe J, Grier HE, Klar N, Levin SB, Ellembogen JM, Salem-Schatz S, et al. Symptoms and suffering at the end of life in children with cancer. N Engl J Med. 2000b;342(5):326-33.

Wolfe J, Klar N, Grier HE, Duncan J, Dalem-Schatz S, Emanuel EJ, et al. Understanding of prognosis among parents of children who died of cancer: impact on treatment goals and integration of palliative care. JAMA. 2000a; 284(19):2469-75.

Wood F, Simpson S, Barnes E, Hain R. Disease trajectories and $\mathrm{ACT} / \mathrm{RCPCH}$ categories in paediatric palliative care. Palliat Med. 2010; 24(8):796-806.

World Health Organization (WHO). Definition of palliative care. [20 jul 2009]. Disponível em: <http://www.who.int/cancer/palliative/definition/en/> Acesso em: 29 jan 20112. 
Wright LM, Leahey M. Enfermeiras e famílias: um guia para avaliação e intervenção na família. 2002. São Paulo: Roca, 2002.

Wright LM. One idea for healing families and communities: soften suffering through spiritual care practices. J Fam Nurs. 2008; 14(4):394-411.

Zanei, SSV. Análise dos instrumentos de avaliação de qualidade de vida WHOQOL- bref e SF-36: confiabilidade, validade e concordância entre pacientes de Unidades de Terapia Intensiva e seus familiares [doutorado]. São Paulo: Escola de Enfermagem, Universidade de São Paulo; 2006.

Zelcer S, Cataudella D, Cairney AE, Bannister SL. Palliative care of children with brain tumors: a parental perspective. Arch Pediatr Adolesc Med. 2010;164(3):225-30.

Zorzo JCC. A criança com câncer em cuidados paliativos e suas famílias: um estudo etnográfico [tese]. Ribeirão Preto: Escola de Enfermagem de Ribeirão Preto, 2010. 